PEDRO PULZATTO PERUZZO

\title{
DIREITOS HUMANOS, POVOS INDÍGENAS E INTERCULTURALIDADE
}

\begin{abstract}
Dissertação apresentada para a obtenção do grau de mestre no programa de pós-graduação em Direito da Faculdade de Direito da Universidade de São Paulo, no ano de 2011, sob a orientação do professor Dr. Eduardo C. B. Bittar.
\end{abstract}




\section{SUMÁRIO}

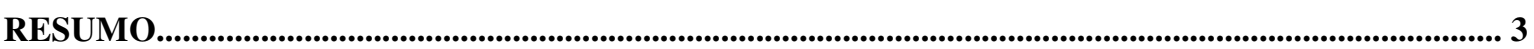

AGRADECIMENTOS ................................................................................................................................... 4

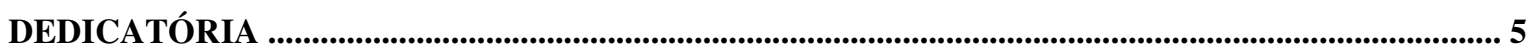

INTRODUÇÃ

CAPÍTULO 1

A TEORIA CRÍTICA E A DIVERSIDADE CULTURAL ..................................................................... 19

\section{CAPÍTULO 2}

PLURALIDADE CULTURAL: A PROPOSTA DA INTERCULTURALIDADE

2.1. Contribuições da Antropologia ao Direito .......................................................................................... 31

2.2. Interculturalidade e multiculturalismo: onde acaba o colonialismo?..................................................... 50

2.3. O outro em mim e as lutas políticas por direitos .......................................................................................... 65

CAPÍTULO 3

DISCURSO, DIÁLOGO E HERMENÊUTICA INTERCULTURAL

3.1. A questão do discurso ........................................................................................................................................ 79

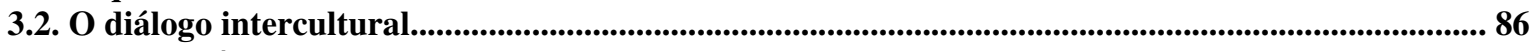

3.3. A hermenêutica intercultural ..................................................................................................... 93

CAPÍTULO 4

DIÁLOGO INTERCULTURAL E EDUCAÇÃO PARA OS DIREITOS HUMANOS 109

CAPítulo 5

UM BALANÇO A PARTIR dOS SISTEMAS REgIONAIS DE PROTEÇÃo DOS DIREITOS

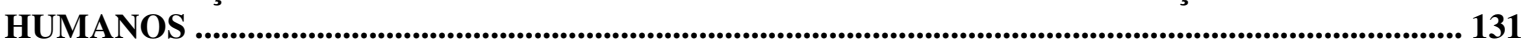

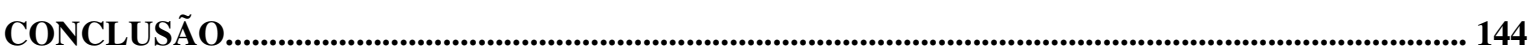

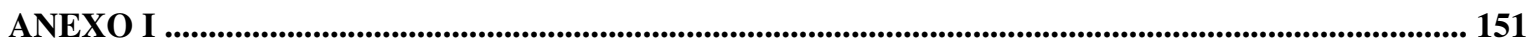

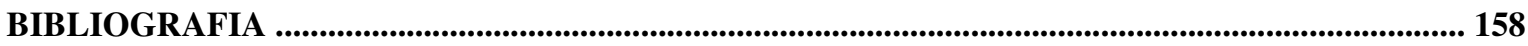




\title{
RESUMO
}

Considerando a atual situação dos povos indígenas no Brasil e a necessidade de se inserir no Direito a proposta de diálogo intercultural, na presente pesquisa tem-se como objetivo situar o Direito como fruto de discursos históricos e políticos decorrentes de influências de algumas correntes antropológicas e filosóficas que tomaram o "outro" como "sujeito de pesquisa" e, a partir dessa análise, identificar as necessidades e vias possíveis para a implementação do diálogo intercultural enquanto processo discursivo simétrico de construção de consensos.

\begin{abstract}
Considering the current situation of the indigenous peoples in Brazil and the need to introduce in the Science of Law the proposal of intercultural dialogue, this research aims to identify the Science of Law as a result of certain historical and political discourses arising from the anthropological and philosophical studies that took the "other" as a "research subject" and, from this analysis, to identify possible ways and needs for the implementation of the intercultural dialogue as a discursive symmetric process to building consensus.
\end{abstract}

\section{RESUMEN}

Considerando la situación actual de los pueblos indígenas en Brasil y la necesidad de introducir en el Derecho la propuesta del diálogo intercultural, esta investigación tiene como objetivo ubicar al Derecho como resultado de discursos históricos y políticos que advienen de la influencia de algunas corrientes de pensamiento antropológico y filosófico que tomaron "el otro" como "sujeto de investigación", y partiendo de ese análisis, identificar las necesidades y caminos posibles para la implementación del diálogo intercultural como proceso discursivo simétrico de construcción de consensos. 


\section{AGRADECIMENTOS}

Inicialmente, consigno meus agradecimentos ao professor Eduardo Carlos Bianca Bittar pela confiança depositada em meu trabalho. As dificuldades para o desenvolvimento de pesquisas interdisciplinares nos cursos de Direito ainda estão presentes nas faculdades de todo país, obstaculizando pesquisas e o desenvolvimento de reflexões relevantes para um mundo plural. $\mathrm{O}$ apoio, os ensinamentos, as aulas, as conversas e as recomendações que me foram proporcionados durante toda a pesquisa foram responsáveis não só pela possibilidade de desenvolvimento deste trabalho na Faculdade de Direito da USP, mas também, e principalmente, pela possibilidade de me desenvolver enquanto ser humano. Não podia ser diferente o resultado diante da postura ética e da honestidade intelectual que sempre orientaram a vida acadêmica desse professor que, a cada dia mais, admiro e considero como um grande amigo.

Não poderia deixar de consignar meus agradecimentos também à professora Vivian Grace Fernándes-Dávila Urquidi, que com tanto carinho e paciência acompanhou meus estudos desde 2008 no grupo pertencente ao projeto Descolonização na América Latina e os e Estados Plurinacionais. Agradeço por todas as orientações, críticas, sugestões e pelo estímulo, fatores importantíssimos para o percurso que percorri e que pretendo continuar percorrendo.

Agradeço aos meus pais, pessoas fundamentais para que eu pudesse desenvolver esta pesquisa onde desenvolvi, quando desenvolvi e do modo como desenvolvi. Agradeço sempre a educação sensível, a sensibilidade na educação, o carinho, o amor e a esperança que me foi plantada para lutar por um mundo melhor.

Agradeço também à Vanessa Teixeira, companheira de pesquisa e de ideias desde 2008, cuja presença nas minhas reflexões foram essenciais para o curso que tomou este trabalho. Agradeço pela posição crítica e firme, pela revisão deste trabalho, bem como pela amizade que, espero, possa se solidificar mais e mais a cada dia. Espero que nossa parceria esteja apenas no início.

Agradeço, por fim, a todos os amigos que já caminhavam ao meu lado e os que conheci durante minha pesquisa, não somente pela troca de impressões, bibliografias, mas principalmente pelo carinho e pelo apoio, pelas conversas e conselhos que me confortaram nos momentos de angústia. E aqui agradeço também à minha irmã Isabela, pelos auxílios inestimáveis com as leituras de Psicanálise. 
Dedico esta pesquisa aos povos indígenas, na esperança de que a luta, ainda que grande e complexa, seja emancipadora para todos nós. 


\title{
INTRODUÇÃO
}

\author{
A fumaça \\ A pequena casa entre árvores no lago. \\ Do telhado sobe fumaça. \\ Sem ela, \\ Quão tristes seriam \\ Casa, árvores e lago!
}

(Bertold Brecht)

A proposta de discutir, a partir do Direito, o tema do diálogo intercultural como forma de abertura para a participação política dos povos indígenas no Brasil tem como justificativa a sensação ${ }^{l}$ de que o etnocentrismo que caracterizou a relação colocnial do ocidente com outras culturas é um obstáculo global para uma democracia efetivamente concretizada a partir de um processo político inclusivo fundado não na tolerância, mas na convivência entre os diferentes. Neste sentido, entendemos a democracia como um sistema em que estaria garantida a participação e a representação de cada cultura sem que houvesse imposição de uma língua oficial, uma religião oficial ou uma estrutura, direito ou governo oficial construídos etnocentricamente.

A proposta da presente pesquisa é decorrência de uma disposição que assumimos de maneira muito clara no sentido de não nos contentarmos com leis sem aplicação prática e que, no Brasil, “deitadas eternamente em berço esplêndido”, não dignificam e nem garantem para as minorias culturais (quantitativas ou qualitativas) o que quer que seja de razoável e minimamente suficiente para a promoção da humanidade que nelas existe.

É a concepção plural da humanidade que pretendemos resgatar nesta pesquisa através da proposta da interculturalidade como experiência sensível. É na sensibilidade cada vez mais oculta em nossos tempos que vemos a possibilidade de encontro com a humanidade existente nos mais simples detalhes. Bertold Brecht no fragmento poético em epígrafe descreve a sensibilidade aos detalhes que todo ser

\footnotetext{
1 "Sensação", aqui, tem uma conotação específica de ausência de precisão teórica, pela falta (e a dificuldade) de contato com os estudos a esse respeito no início do trabalho.
} 
humano deve assumir diante do Humano para que seja possível vivermos a interculturalidade como experiência sensível. A sensibilidade de Brecht ao ver a humanidade na fumaça é o que nos anima a propor as idéias que desenvolveremos neste trabalho.

Consideramos importante esclarecer nesta parte introdutória que a presente pesquisa teve origem em um estudo desenvolvido em iniciação científica empreendido nos anos de 2005 e 2006, com foco na flexibilidade da noção de igualdade diante das diferenças. O que interessa particularmente é o relato das dificuldades encontradas tanto para estudar o tema, como para definir conceitos e até mesmo o nosso objeto.

Parece-nos interessante anotar esse percurso metodológico, pois durante a iniciação científica e considerando o modelo de ensino jurídico que ainda vige nas faculdades de Direito de todo o país, pensar em um processo político de realização dos direitos humanos e, mais do que isso, em um processo político situado na hermenêutica e na experiência sensível de convivência, ou seja, para além dos legisladores abstratos, somente foi possível em grupos vinculados a projetos de outros cursos (o nosso grupo era vinculado à Faculdade de Filosofia) ${ }^{2}$.

Nossa hipótese assumia uma feição sutil de inquietude, dúvida, de sentimento de incoerência diante da realidade e dos dispositivos e doutrinas constitucionais que diziam ser a República Federativa do Brasil um estado democrático de direito, fundado na dignidade da pessoa humana, no pluralismo político, com o objetivo de construir uma sociedade livre, justa e igualitária, visando a erradicação da pobreza, da marginalização e das desigualdades sociais e promovendo o bem de todos sem preconceito de origem, raça, sexo, cor e idade (artigos $1^{\circ}$ e $3^{\circ}$ da Constituição Federal do Brasil). A concretização prática dessas ideias, dessas sensações, era algo quase impossível de ser feito dentro das matérias que compunham a grade curricular formal, e isso nos perturbava.

Concluídos os estudos em iniciação científica, muito nos chamou a atenção o tópico social e político da diferença cultural especificamente, fato que nos fez optar por continuar trabalhando com o tema na monografia de conclusão de curso. No

\footnotetext{
${ }^{2}$ A linha de pesquisa da Faculdade de Filosofia da PUC-Campinas era Filosofia, Sociedade e Cultura e o grupo da Faculdade de Direito, coordenado pelo professor Dr. Samuel Mendonça era Direitos Humanos e Modernidade, ocasião em que desenvolvemos projeto de iniciação científica sobre o tema "O Problema da Hermenêutica para a Análise dos Direitos Humanos".
} 
trabalho monográfico, ${ }^{3}$ decidimos analisar os sistemas regionais de proteção dos direitos humanos, conferindo especial atenção para os sistemas islâmico, latinoamericano, africano, oriental e indígena.

A opção por analisar os sistemas regionais especificamente tinha como justificativa a sensação de que os discursos universalizantes, normalmente com referência à Organização das Nações Unidas, marginalizavam inúmeras expressões culturais. À época, o que nos chamou a atenção, principalmente, foi a forma eurocêntrica que assumiam os discursos contra as questões de gênero na África e no Islã e os discursos acerca do progresso (ou ausência, entrave ao progresso) em relação aos povos indígenas no Brasil.

A partir desses estudos que, em certa medida serão retomados no curso deste trabalho, a sensação inicial de que algo de estranho havia na forma que nos era ensinado "pensar e aplicar o Direito", ou seja, enquanto uma forma de homogeneização cultural, passou a perder a conotação de mera sensação e acabou assumindo uma natureza de hipótese a ser demonstrada e confrontada com os discursos então vigentes nos cursos de Direito.

Ainda dominados por uma inquietude, e com os pés fixados em preconceitos nascidos pela própria leitura do ordenamento jurídico nacional (passado e vigente) ${ }^{4}$ decidimos iniciar um projeto de mestrado procurando encontrar manifestações oriundas dos próprios indígenas que, no âmbito nacional, justificassem uma conclusão de que o regime democrático anunciado no ordenamento jurídico vigente estava muito aquém da dimensão política e cultural que expressa a viva noção de "povo brasileiro".

Após um período de pesquisa exploratória por meio virtual na rede mundial internet, descobrimos dois interessantes documentos elaborados pelos próprios representantes indígenas e, o que nos pareceu mais interessante, por representantes de

\footnotetext{
${ }^{3}$ PERUZZO, P. P. A tutela das diferenças a partir dos sistemas regionais de proteção dos direitos humanos. 2007 (Monografia de conclusão de curso sob orientação do Dr. Luis Renato Vedovato).

${ }^{4}$ A nálise de alguns documentos e dispositivos legais evidencia esse preconceito:

I - Constituição de 1967: Art $8^{\circ}$ - Compete à União: (...)XVII - legislar sobre: (...) o) nacionalidade, cidadania e naturalização; incorporação dos silvícolas à comunhão nacional;

II - Estatuto do índio: Art. $1^{\circ}$ Esta Lei regula a situação jurídica dos índio ou silvícolas e das comunidades indígenas, com o propósito de preservar a sua cultura e integrá-los, progressiva e harmonicamente, à comunhão nacional.

III - Constituição de 1998: Art. 232. Os índios, suas comunidades e organizações são partes legítimas para ingressar em juízo em defesa de seus direitos e interesses, intervindo o Ministério Público em todos os atos do processo.
} 
povos indígenas de todo o mundo reunidos no Brasil no mesmo momento (porém paralelamente) em que ocorria a Rio $92 .{ }^{5}$ Esses dois documentos são a Carta da Terra dos Povos Indígenas ${ }^{6}$ de 1992 e a Declaração da Aldeia Kari-oca.

Na Carta da Terra de 1992 consta:

56. O círculo vital segundo os Povos Indígenas está continuamente interligado e qualquer mudança afeta seu todo.

57. As mudanças climáticas afetam tanto os Povos Indígenas como toda a humanidade, ocasionando total desequilíbrio ecológico. Recomendamos que isso seja evitado, pois ocasionará prejuízos à agricultura e à qualidade da vida.

64. Qualquer estratégia de desenvolvimento deve priorizar a eliminação da pobreza, a garantia relativa ao clima, a administração sustentável dos recursos naturais, a continuidade das sociedades democráticas e o respeito às diferenças culturais.

77. A noção eurocêntrica de propriedade está destruindo nosso povo. Nós devemos retornar para a nossa visão do mundo, da terra e do desenvolvimento. Este tema não deve ser separado dos direitos dos povos indígenas.

78. Há diferentes formas de desenvolvimento, como a construção de estradas, comunicações, eletricidade, que facilitam acesso às terras dos Povos Indígenas. Essa industrialização tem efeitos destrutivos sobre nossos povos.

A Carta da Terra é um documento que foi elaborado no Brasil em 30 de maio de 1992, juntamente com a Declaração da Aldeia Kari-Oca. Essas duas declarações de direitos foram elaboradas por ocasião da Conferência Mundial dos Povos Indígenas sobre Território, Meio Ambiente e Desenvolvimento, organizada por índios componentes do Comitê Intertribal - 500 Anos de Resistência. ${ }^{7}$

A Kari-Oca, posteriormente destruída por um incêndio de natureza presumidamente criminosa, foi idealizada por sete povos do Alto Xingu - MT e o povo Tukano, do Amazonas, com a finalidade de servir como um templo indígena. Nas

\footnotetext{
${ }^{5}$ A Rio 92 foi a Conferência das Nações Unidas para o Meio Ambiente e o Desenvolvimento, que ocorreu no Rio de Janeiro de 03 a 14 de junho de 1992.

6 Importante anotar que a ONU organizou um documento também denominado Carta da Terra, mas que não se confunde com esse documento por nós analisado. Guilherme Assis de Almeida, no texto Soberania, cosmopolitismo e o direito internacional dos direitos humanos, analisa a Carta da Terra da ONU como um documento surgido na fase de responsabilização individual em relação ao Direito Internacional dos Direitos Humanos. Conferir texto disponível no seguinte sítio eletrônico $<$ http://www.nevusp.org/downloads/down075.pdf > Acesso em 20 de novembro de 2011.

7 <http://www.culturabrasil.org/cartadaterra.htm> Acesso em 20 de outubro de 2011.
} 
palavras de Marcos Terena, Coordenador Geral do Projeto: Plantada como folclore, mas para nós, um código de vida jamais decifrado pelo homem branco. ${ }^{8}$

O que chama a atenção nesses documentos é a ampla representatividade de povos indígenas que participaram da sua elaboração, bem como do significado que esses documentos assumem diante dos documentos ditos universais. No preâmbulo da Declaração da Aldeia Kari-Oca consta os povos indígenas que participaram de sua elaboração: Nós, Povos Indígenas das Américas, Ásia, África, Austrália, Europa e Pacífico, unidos em uma só voz na Aldeia Kari-Oca, expressamos a nossa gratidão coletiva aos povos indígenas do Brasil. $\mathrm{O}$ artigo $3^{\circ}$ da Carta da Terra, por sua vez, recomenda que os governos apóiem o Grupo de Trabalho dos Povos Indígenas nas Nações Unidas, para que possam chegar a uma Declaração Universal sobre Direitos Indígenas que, à época, estava em "estudo final". 9

Não obstante o pedido de apoio para a conclusão da Declaração de Direitos dos Povos Indígena da ONU, alguns artigos desses documentos indígenas evidenciaram o déficit de representatividade efetiva no âmbito da ONU. A Carta da Terra dispôs: A ONU deve estar capacitada para enviar indígenas representativos, para manter a paz em territórios indígenas onde haja ameaça de conflitos, ajudando a preveni-los. Ainda, no artigo 13 dispôs: Nossos sistemas de governos indígenas e os sistemas legais devem ser reconhecidos pela ONU. Complementa o artigo 22: As convenções assinadas entre Povos Indígenas e não indígenas devem ser acatadas como formas legais e de direito internacional.

Durante o curso da presente pesquisa em nível de mestrado nos aproximamos de alguns movimentos sociais e de algumas lideranças indígenas. ${ }^{10} \mathrm{~A}$ experiência com as preocupações dos movimentos sociais indígenas possibilitou a realização de um corte empírico inexistente no início da pesquisa, qual seja, a atenção para um aspecto específico da relação entre Estado e povos indígenas. Esse corte

\footnotetext{
${ }^{8}$ TERENA, Marcos. Disponível em: <http://www.culturabrasil.pro.br/zip/cartadaterra.rtf $>$. Acesso em 19 de outubro de 2007.

${ }^{9}$ Essa declaração somente passou a valer, para os Estados que a assinaram no âmbito da ONU, em setembro de 2007, ou seja, quinze anos após o documento da aldeia Kari-Oca.

${ }^{10}$ No início da pesquisa acompanhamos o desenvolvimento, em São Paulo, do ponto de cultura "Casa dos saberes indígenas". Posteriormente passamos a acompanhar a trajetória do indígena tupinambá Israel Raimundo dos Santos (Sassá Tupinambá) frente ao grupo de trabalho indígena no Tribunal Popular da Terra (organização de vários movimentos sociais de nível nacional que, por questões ideológicas, não possui centralização administrativa e nenhuma forma jurídica institucionalizada, como ONG, associação etc.). Tivemos a oportunidade de desenvolver conversas pontuais com outras lideranças, mas a proximidade maior se deu com os projetos do Tribunal Popular da Terra na cidade de São Paulo.
} 
empírico foi importante para separarmos as demandas indígenas do cenário de homogeneidade estatal. A doutrina antropológica consultada e que será analisada no curso desta pesquisa trabalha a relação entre povos indígenas e Estado; no entanto, o aspecto dessa relação que nos chamou atenção foi exatamente a problemática do reconhecimento que reside na necessidade dos grupos indígenas de se organizarem em instituições jurídicas distintas das instituições tradicionalmente reconhecidas por suas culturas, sob pena de permanecerem invisíveis aos olhos do Estado e do Direito.

Ainda no que diz respeito à experiência de campo, em 2010 foi aprovada a Lei Municipal de São Paulo nº 15.248/2010, que cria o Conselho Municipal dos Povos Indígenas. ${ }^{11}$ Essa lei decorre de um projeto de lei proposto pela vereadora Juliana Cardoso, tendo sido objeto de amplo debate junto às comunidades indígenas. Acompanhamos também o processo ainda não concluído do ciclo de negociações para a eleição dos membros do conselho. Os debates permanecem em curso, no entanto, essa experiência de campo suscitou um novo ponto de reflexão referente à relação entre Estado e povos indígenas (em uma perspectiva de participação política), qual seja, a insuficiência de conquistas junto ao Poder Legislativo, demonstrando a inafastabilidade dos movimentos sociais no sentido das pressões sobre as instâncias concretizadoras das leis e dos princípios abertos do Direito.

Na primeira reunião do Conselho ficou bastante claro que a referida lei só havia sido sancionada pelo chefe do Poder Executivo em razão de seu caráter bastante amplo, não definido. A título de exemplo, inexistia disposição expressa a respeito do fato de ser, ou não, um indígena o presidente do Conselho, bem como se caberia a um indígena eventual voto de minerva. Essas e outras questões de interesse para a efetiva participação dos povos indígenas se mostraram sujeitas a decretos regulamentares do Poder Executivo, havendo sérias preocupações com alterações prejudiciais em razão de alteração de conjuntura política.

Ainda em razão das experiências empíricas, nos deparamos com a necessidade de alterar o foco também em outro aspecto do projeto inicial. A visita a aldeias e organizações sociais como a aldeia Guarani do Pico do Jaraguá, os Kariri de Cotia, os Guarani de Parelheiros, os Wassu-Cocal de Guarulhos e outros indígenas que habitam o espaço urbano, nos fez sentir a necessidade de conferir foco à conjuntura política da questão indígena no Brasil. Nos deparamos com uma intensa disparidade de

${ }^{11}$ O Conselho Municipal dos Povos Indígenas tem por objetivo subsidiar a elaboração, implementação, acompanhamento e avaliação da política municipal de atenção aos povos indígenas. 
condições materiais (políticas, culturais, de subsistência) entre os mais diversos grupos indígenas no Brasil que, aliás, estão diretamente relacionadas aos principais objetivos de suas demandas.

Essa proposta de análise conjuntural, apesar de não prevista no projeto de pesquisa original, proporcionou o pretendido desenvolvimento da presente pesquisa a partir dos referenciais teóricos da Teoria Crítica, conforme melhor se esclarecerá no tópico seguinte. A análise conjuntural inevitavelmente exigiu o percurso por dois temas centrais da Teoria Crítica, quais sejam: 1- reconhecimento vs. distribuição; 2 - indústria cultural.

O debate entre Axel Honneth e Nancy Fraser ${ }^{12}$ acerca das políticas de distribuição e reconhecimento colocaram em pauta não a necessidade de optar por um ou outro, mas essencialmente a necessidade de se refletir a conjuntura em que se desenvolve o objeto de análise do presente trabalho, ou seja, a participação política indígena.

Os Guarani que habitam o Jaraguá vivem em situação de extrema pobreza, tendo como demanda central o acesso à terra como forma de superação do problema da fome. Os Kaiapó do Pará, apesar de viverem em condições alimentares regulares, ou ao menos distintas dos Guarani do Jaraguá, atualmente têm aparecido no espaço público para reivindicar o direito ao reconhecimento de sua cultura, especialmente no que diz respeito ao vínculo tradicional existente com o espaço geográfico em que habitam. Ameaçados culturalmente pelo projeto da Usina de Belo Monte, os Kaiapó têm como demanda essencial o reconhecimento, de modo que possam, a partir desse reconhecimento, evitar que se vejam, dentro de alguns anos, demandando distribuição a partir de políticas compensatórias de supressão de déficit alimentar. ${ }^{13}$ Os Wassu-cocal que vivem na cidade de São Paulo encontram-se em uma situação bastante peculiar. Tentando "formalizar" em associação a organização das mais de 20 famílias pertencentes ao mesmo povo que habitam o mesmo espaço urbano, veem-se obrigados a recorrer a um sem número de pessoas mal intencionadas para terem acesso a um computador para redigir o estatuto da associação e acompanhar o lançamento de editais públicos de projetos culturais. Se distribuição (acesso a

\footnotetext{
12 FRASER, Nancy. HONNETH, Axel. ¿Redistribución o reconocimiento? Un debate político-filosófico. Trad. Pablo Manzano. Madrid: Ediciones Morata, 2006.

${ }^{13}$ A Usina de Belo Monte é um projeto a ser desenvolvido na bacia do Rio Xingu, no Estado do Pará, e terá como impactos a inundação de certas áreas e o esvaziamento do rio em outras, atingindo dezenas de comunidades indígenas e ribeirinhas. A licença ambiental foi concedida pelo Ministério do Meio Ambiente em fevereiro de 2010.
} 
computadores) ou reconhecimento, a questão, ao menos aparentemente, não reside na prevalência de um sobre o outro, mas na necessidade de compreensão de se tratar de medidas que, em muitos casos, caminham lado a lado, como, aliás, afirmou Axel Honneth em seu texto Reconhecimento ou redistribuição? A mudança de perspectivas na ordem moral da sociedade:

(...) Essa circunstância, em meu ponto de vista, demonstra que as regras de
distribuição não podem ser simplesmente derivadas das relações de produção,
mas deve, sem ser vistas como a expressão institucional de um dispositivo
sociocultural que determina qual grau de estima atividades específicas ocupam
em um determinado momento. (...) Uma vez que estamos conscientes desse
significado da luta por reconhecimento, então um desafio premente às
democracias ocidentais desenvolvidas se torna imediatamente evidente. Por
causa do desemprego, que não está mais meramente ligado aos ciclos
econômicos, mas é agora também estrutural, um número crescente de pessoas
não têm a oportunidade de ganhar o tipo de reconhecimento por suas habilidades
adquiridas que eu refiro como estima social. Por causa disso, eles mal podem se
considerar membros contribuintes de uma comunidade democrática organizada,
já que isso pressupõe a experiência de cooperação, ou seja, a contribuição
socialmente reconhecida para a reprodução social. ${ }^{1{ }^{4}}$

Ainda nessa linha, vale citar Boaventura de Sousa Santos, que diz: Daí que uma política emancipatória de direitos humanos deva saber distinguir entre a luta pela igualdade e a luta pelo reconhecimento igualitário das diferenças a fim de poder travar ambas as lutas eficazmente. ${ }^{15}$

Durante a experiência de campo, sentimos também a necessidade de readequar a abordagem antropológica do objeto da pesquisa, que será objeto do segundo capítulo. As leituras que fizemos de obras antropológicas deixaram evidente que existem diversas discussões sobre cultura indígena, havendo aspectos peculiares, recortes específicos e, em relação ao próprio conceito de "cultura" existem debates no seio da própria Antropologia que não conseguem atingir um consenso.

Considerando nossa formação exclusivamente jurídica, bem como o fato de estarmos analisando a participação política dos povos indígenas e o diálogo intercultural a partir da perspectiva do Direito e dos direitos humanos historicamente situados, notamos que os relatos etnográficos podem integrar nossa pesquisa de forma auxiliar, como forma de demonstrar a existência de diferenças culturais, os sentidos sociais e individuais dessas diferenças e a complexidade de que se reveste a humanidade que, em termos iluministas, se pretendeu (e em certa medida ainda se pretende) universal. No entanto, não adentraremos em questões de divisão de poder político dentro das aldeias, já

\footnotetext{
${ }^{14}$ HONNETH, Axel. In. Teoria crítica no século XXI. Org. Jessé Souza e Patrícia Mattos. p.79-93.

${ }^{15}$ SANTOS, Boaventura de S. A Gramática do Tempo: para uma nova cultura política. 3. Ed. São Paulo: Cotez Editora, 2010. p. 447.
} 
que esse estudo desviaria o foco que pretendemos conferir ao presente trabalho, ou seja, a relação colonial ainda existente entre Estado-nacional versus Diferenças culturais e entraria em questões específicas de cada comunidade indígena.

O referencial teórico antropológico, portanto, pautar-se-á não em uma bibliografia etnográfica, mas essencialmente em uma bibliografia que analisa o método de pesquisa antropológica e os impactos e relações que a Antropologia teve no Direito desde a virada do século XIX até hoje.

Por fim, tivemos um último salto conceitual que conferiu mais precisão ao objeto do nosso trabalho. No curso dos nossos estudos chegamos a nos deparar com a hipótese de que o obstáculo à convivência democrática e dialógica entre diferentes culturas seria o próprio Direito oficial, enquanto instrumento estatal homogeneizador de comportamentos. O Direito oficial, nessa linha, seria um instrumento utilizado pelo Estado nacional (que também foi uma noção que no início compreendemos de forma "totalizante" e abstrata) para essa finalidade homogeneizante, instrumentalizada pelo argumento do "uso legítimo da força".

Essas conclusões exigiram de nossos estudos a análise dos argumentos utilizados pela noção de Direito que estávamos tomando como objeto para justificar essa intenção de homogeneização de condutas (principalmente de práticas culturais) e, nesse curso empírico, nos detivemos nos seguintes argumentos: 1- a nação teria um horizonte comum de expectativas; 2- o Estado de direito e soberano seria o instrumento e o legitimador para essa busca; 3- o foco dos direitos seria o sujeito de direito; 4- existiria uma concepção universal de direito possível.

O enfrentamento do problema da homogeneização de condutas com base em noções abstratas de Direito e de Estado orientou nossas reflexões durante grande parte de nossa pesquisa. Afinal, essa forma de encarar o problema é decorrência não apenas de um equívoco particular, mas de uma confusão que é verticalmente imposta a qualquer estudante de Direito que, desde o primeiro ano da graduação (salvo raras e admiráveis exceções de professores com formação crítica), como expusemos acima, é induzido a pensar o Direito como um sistema fechado, rígido e, nesse fechamento e nessa rigidez, satisfazer uma ânsia de segurança e previsibilidade jurídicas. Além disso, essa segurança, pelos próprios discursos dos educadores, só poderia ser obtida pela compreensão do Direito que tivesse como pressupostos os quatro argumentos citados no final do parágrafo anterior, que induziram a nossa conclusão de que o Direito, por si 
mesmo, seria um obstáculo a ser enfrentado e afastado para que fosse possível a interculturalidade nos termos que pretendemos sugerir neste trabalho.

Ainda que estivéssemos viciados por essa noção abstrata de Direito e de Estado, após entrarmos em contato com algumas questões que denominaremos "questões-chave" da interculturalidade, fomos compelidos (e, de certa forma, autorizados) a conferir novo rumo às nossas reflexões. Essas questões-chave da interculturalidade são as seguintes: 1- todo agrupamento social tem algum conjunto de normas que pode ser entendido como sendo Direito, ainda que não emanem de um Estado formado a partir da idéia de Estado-nacional, ainda que não tenham como destinatário principal o sujeito de direito, ainda que não pressuponham nem um horizonte comum e nem uma nação e, por fim, ainda que estejam distantes do ideal de uma concepção universal de Direito; e 2- a interculturalidade, especificamente o diálogo intercultural, deverá ter como pressuposto alguma regra que garanta o equilíbrio dialógico, sob pena de a proposta dialógica restar frustrada pela supremacia do discurso colonial que ainda tem vigor na América Latina (onde existem importantes contatos interculturais), importando saber, neste caso, "que regras" serão essas.

O fato de que todo agrupamento social tem alguma forma de Direito nos fez buscar argumentos para problematizar a intenção de homogeneidade não num Direito abstratamente considerado, mas na ideia do "Direito oficial", e mais, do Direito oficial construído por apenas uma cultura. Ainda que a adjetivação do Direito como "oficial” já pudesse proporcionar às nossas reflexões um curso mais definido para a discussão do diálogo intercultural e exclusão e opressão de culturas não-ocidentais (no caso, os povos indígenas), essa ideia de "Direito oficial" nos exigiu ainda mais um esforço de contextualização, qual seja, a situação histórica dessa concepção de Direito dentro do projeto racionalizante nascido com a Revolução Francesa de 1789.

Em verdade, fizemos um retorno de situação. Inicialmente situamos o Direito que gostaríamos de analisar dentro do projeto universalizante da Modernidade, mas fizemos isso sem situar essa concepção de Direito no espaço político latino-americano, que exige a consideração de outros fatores imprescindíveis.

Esse projeto racionalizante da Modernidade em sua concretização política latino-americana encontrou na figura do "Estado nacional" a solução (ao menos retórica) para os anseios de um mundo que, a partir de um processo de industrialização e tecnicização da produção com base na liberdade contratual, no evolucionismo cultural, no livre fluxo de capitais e na aceleração a qualquer preço do trânsito infinito de mercadorias 
(consumismo), conferiria segurança àquilo que se desenvolveu como capitalismo. As consequências desse projeto no mundo, e especificamente na América Latina, assegurou não o desenvolvimento, mas a perpetuação da situação colonial, que será objeto de análise no curso deste trabalho de forma mais detida.

A reflexão da Modernidade e seus reflexos a partir da América Latina é um esforço bastante relevante para a presente pesquisa e, além de relevante, justificável, pois permite pensarmos ao mesmo tempo modernidade e colonialismo. Nesse particular, vale citar Boaventura de Sousa Santos:

Nos últimos anos tenho me convencido que aprender com o Sul é uma exigência
que, para ser levada a sério, obriga algumas reformulações na teorização que venho
propondo. Como referi, a designação pós-moderno nunca me satisfez, tanto mais
que a hegemonia do pós-moderno celebratório tornou virtualmente impossível fazer
vingar a alternativa do pós-moderno de oposição. Por outro lado, a idéia da pós-
modernidade aponta demasiado para a descrição que a modernidade ocidental fez de
si mesma e nessa medida pode ocultar a descrição que dela fizeram os que sofreram
a violência com que ela lhes foi imposta. Essa violência matricial teve um nome:
colonialismo. Sta violência nunca foi incluída na auto-representação da modernidade
ocidental porque o colonialismo foi concebido como missão civilizadora dentro do
marco historicista ocidental nos termos do qual o desenvolvimento europeu
apontava o caminho ao resto do mundo, um historicismo que envolve tanto a teoria
política liberal como o marxismo. $(. . .)^{16}$ Assim, quando vinculamos a noção de Direito à concepção de Estado nacional e à ideologia que pode ser representada em termos de "Modernidade", alcançamos a maturidade conceitual daquilo que, no início, se nos apresentou de forma distorcida e, em certo momento, nos impediu de caminhar no sentido da construção de uma proposta de interculturalidade e diálogo intercultural para o Direito. Além dessa maturação conceitual que alcançamos pela contextualização do Direito ocidental homogeneizante no projeto racionalizante da Modernidade e dos reflexos coloniais que ainda permanecem vivos na América Latina, o fato de termos constatado a possibilidade de pensar Direitos (no plural) a partir da ideia de que existem outras configurações de Direito em outras culturas, o que nos foi proporcionado pelo contato com a Antropologia do Direito, especialmente pelas leituras que fizemos de Bronislaw Malinowski, ${ }^{17}$ chegamos à

\footnotetext{
${ }^{16}$ Op. Cit. p. 28.

${ }^{17}$ Malinowski desenvolve essa ideia em duas obras principais, quais sejam, Os Argonautas do Pacífico Ocidental (São Paulo: Ed. Abril, 1978) e Crime e Costume na Sociedade Selvagem (Brasília, Editora da UnB, 2003). No entanto, vale consignar que essa concepção não foi uma questão pacífica na Antropologia. Boaventura de Sousa Santos, na obra $O$ discurso e o poder, explica de maneira bastante didática a questão: Esta tensão tem as suas raízes nas obras de dois fundadores da antropologia jurídica, Malinowski e Radcliffe-Brown. Malinowski parte do pressuposto de que em todos os povos, qualquer que seja o grau do seu "primitivismo", existe direito e consequentemente propõe uma estratégia conceitual em que o objetivo da generalidade se sobrepõe ao da especificidade. (...)Radcliffe-Brown, o contrário, segue uma estratégia
} 
conclusão de que o problema da homogeneização cultural não pode ser analisado a partir de uma concepção abstrata de Direito e Estado, mas sim nos discursos que conferem sentido/conteúdo às normas que integram esse Direito e às práticas que orientam a ação desse Estado. Isso pressupõe a compreensão do Direito e do Estado como instituições polifônicas que existem concretamente, especialmente na América Latina, como discursos oficiais, porém oriundos de anseios da cultura ocidental sem prévios diálogos com outras culturas.

Se toda sociedade possui alguma organização sistêmica de normas que poderia ser entendida como Direito, a ideia de um Direito que compreendesse e recepcionasse as necessidades de seres humanos pertencentes a culturas distintas, mas que estivessem situados num mesmo espaço geopolítico (o limite, aqui, seria o mundo), não nos parece de todo uma ideia fadada ao insucesso. A questão estaria em como fazer dialogar essas lógicas organizativas de modo que todos os discursos veiculadores de anseios e necessidades pudessem se encontrar em um espaço onde a garantia de simetria dialógica estivesse garantida.

Assim, devemos considerar que a homogeneização cultural é uma intenção típica do Direito ocidental moderno, instrumento de colonização e de segurança ao modo de produção capitalista. Em termos mais precisos, retomando as quatro características dos discursos que, para nós, fundamentam a noção ocidental de Direito ${ }^{18}$, são esses discursos, de fato, os responsáveis pela ocidentalização de uma única idéia de Direito. Em outros termos, a ideia de Direito em si não é uma concepção típica do ocidente, e isso Malinowski deixou claro ao considerar que o Direito, enquanto normas de organização social, pode ser encontrado em outras culturas. $O$ que permite que determinada configuração sistêmica de normas seja definida como Direito ocidental ou, dentro de um Estado nacional, como Direito oficial, são os discursos que conferem sentido às normas que integram essa configuração sistêmica de controle social.

Essa concepção de Direito inseparável dos discursos culturais que lhe conferem sentido não é nova e nem pertence exclusivamente aos avanços da Antropologia. As teorias mais tradicionais já consideravam o Direito positivo como um ato de vontade do legislador; ou seja, como um ato de escolha entre um conjunto de possibilidades de dever

conceitual em que o objetivo da especificidade tem precedência sobre o da genralidade. (...) O que levou à conclusão de que "neste sentido, algumas sociedades simples não têm direito". (Op. Cit. p.70).

${ }^{18}$ 1- a nação teria um horizonte comum de expectativas; 2- o Estado de direito e soberano seria o instrumento e o legitimador para essa busca; 3- o foco dos direitos seria o sujeito de direito; 4- existiria uma concepção universal de direito possível. 
ser que seriam positivadas por esse ato que pressupõe uma escolha. ${ }^{19} \mathrm{O}$ que a Antropologia traz de diferente para esse ato de escolha é a demonstração de que esse conjunto de possibilidades que, em outros termos, é o conjunto de condutas típicas do mundo da vida, exige a compreensão prévia de que o mundo da vida não se resume às práticas culturais do Ocidente. E é exatamente essa premissa que orientará o nosso trabalho no sentido de propor a interculturalidade como um espaço dialógico simétrico de criação de sentido a normas que garantirão a possibilidade de convivência de culturas distintas, e não somente a tolerância de umas pelas outras.

Inicialmente, analisaremos essa primeira premissa, qual seja, que o mundo da vida não se resume ao ocidente. Na sequência, analisaremos o que entendemos como interculturalidade. A seguir desenvolvemos a concepção do Direito como resultado de discursos e sugerimos o diálogo e a hermenêutica intercultural como instrumento de consensos entre discursos culturais distintos. A parte final deste trabalho refletirá a respeito dos obstáculos para a simetria dialógica na interculturalidade e como a educação para os direitos humanos pode contribuir para a emancipação de todos os interlocutores dessa cena dialógica.

Caminhemos, então.

${ }^{19}$ Hans Kelsen já havia desenvolvido essa ideia. Cf. Teoria Pura do Direito. 6.ed. Trad. João Baptista Machado. São Paulo: Martins Fontes, 1999. p.7. As normas através das quais uma conduta é determinada como obrigatória (como devendo ser) podem também ser estabelecidas por atos que constituem o fato do costume. (...) Porém, o sentido subjetivo dos atos constitutivos do costume apenas pode ser interpretado como norma objetivamente válida se o costume é assumido como fato produtor de normas por uma norma superior. Visto o fato do costume ser constituído por atos de conduta humana, também as normas produzidas pelo costume são estabelecidas por atos de conduta humana e, portanto, normas postas, isto é, normas positivas, tal como as normas que são o sentido subjetivo de atos legislativos. Através do costume tanto podem ser produzidas normas morais como normas jurídicas. As normas jurídicas são normas produzidas pelo costume se a Constituição da comunidade assume o costume - um costume qualificado - como fato criador de Direito. Cf. também: HART, Herbert. O conceito de direito. Trad. Antonio de Oliveira S. Camara. Martins Fontes, 2009. 


\section{CAPÍTULO 1 \\ A TEORIA CRÍTICA E A DIVERSIDADE CULTURAL}

Existe um senso comum, por vezes velado, que reconhece a importância das diferenças culturais e também que as populações indígenas têm e sempre tiveram muito a oferecer para a cultura ocidental colonizadora, especialmente no que diz respeito ao trato e ao conhecimento da natureza. No entanto, a cultura ocidental, de forma contumaz, se recusa a dialogar e, até mesmo, a refletir a respeito das vias possíveis de diálogo e convivência. E assim foi desde o primeiro contato entre as duas culturas europeias e americanas. ${ }^{20}$

Como afirma Dalmo de Abreu Dallari: Por isso é indispensável que por todos os meios se proclame que os índios brasileiros são seres humanos, tão cidadãos como os demais brasileiros, tendo os direitos inalienáveis de preservar sua vida e sua liberdade de viver com dignidade. ${ }^{21}$

Nosso objetivo com a presente pesquisa é desenvolver reflexões a respeito de como as comunidades indígenas existentes no contexto territorial da América Latina, com foco específico no Brasil, poderiam usufruir de maneira plena do direito de participar dos assuntos políticos que lhes afetam. Este direito se encontra consignado no artigo 25, a, do Pacto Internacional de Direitos Civis e Políticos e no artigo 23, a, da Convenção Americana de Direitos Humanos. Para tanto, partimos do pressuposto de que somente compreendendo a diferença cultural e suas intensas implicações no diálogo intercultural é possível tratar da participação política indígena. Neste sentido, pensamos em uma nova conjuntura onde a figura do Estado, do Parlamento - desenvolvidos originalmente em termos exclusivamente ocidentais -, não sejam os únicos determinantes para a configuração dos direitos em jogo. Em suma, em uma conjuntura onde as formas tradicionais de organização social indígena sejam reconhecidas enquanto representações legítimas de luta que, no nosso ponto de vista, configura o principal instrumento para a presença ativa no espaço público da cultura indígena enquanto um complexo de interesses e demandas com vistas à garantia de uma vida digna.

\footnotetext{
${ }^{20}$ BARBOSA, Marco Antônio. Autodeterminação - Direito à Diferença. São Paulo: Plêiade, 2001: “(...) enquanto os gentios pareciam estar preocupados em saber se os europeus eram humanos ou divinos, esses últimos queriam estabelecer se aqueles eram ou não dotados de alma”. p.173.

${ }^{21}$ DALLARI, Dalmo de Abreu. In. O Primeiro Habitante. MEDINA, Cremilda (org). Editora USP,

ECA e CJE. 1992. P.244.
} 
A sobrevivência e a manutenção de coesão de uma sociedade plural podem ser vistas como dois dos principais objetivos desse agrupamento e duas das principais tarefas atribuídas aos indivíduos a ele pertencentes. No entanto, essa coesão somente pode ser promovida através de práticas que convirjam a um mesmo conjunto de objetivos centrados na melhoria das condições de vida de cada grupo que conforma a sociedade e na solução dos problemas que permeiam esse conjunto plural e, de certa forma, os seus indivíduos (sob pena de não existir a transformação do objetivo coletivo em interesse pessoal). Nestes contextos a coesão social não pode ser compreendida em termos simplesmente durkheimnianos, ou seja, num sentido de unificação ou vinculação a uma consciência coletiva fatalista e única, de homogeneização, ${ }^{22}$ mas, ao contrário, num sentido plural: em uma coesão que pressupõe não a descaracterização, a alienação, mas a convivência. $^{23}$

O mesmo pode ser dito em relação às culturas, pois se é possível existir a convergência de interesses entre indivíduos de um mesmo grupo, também é possível a convergência de interesse entre culturas diversas existentes em um mesmo espaço, desde que haja respeito e diálogo efetivo. Essa convergência de interesses, no nosso modo de pensar, pode ser viabilizada por um diálogo democrático entre culturas sem imposições discursivas subliminares advindas de uma Indústria $\mathrm{Cultural}^{24}$ ou advindas de instrumentos institucionalizados dentro de uma assimetria de forças, como o Direito, mas em um diálogo intercultural empreendido a partir de um campo semântico crítico e aberto, a ser construído.

Ocorre que a questão do diálogo intercultural ainda é muito pouco debatida no cenário jurídico brasileiro, especialmente no que diz respeito à participação da cultura indígena (que, apesar da mesma legitimidade, tem pautas de reivindicação bem distintas de outras expressões culturais, como é o caso da cultura afro, cigana, islâmica etc.) através de suas comunidades e movimentos, nos assuntos de interesse público, que

\footnotetext{
${ }^{22}$ DURKHEIM, E. A divisão do trabalho social. 1978. O conjunto das crenças e dos sentimentos comuns è média dos membros de uma mesma sociedade forma um sistema determinado que tem sua vida própria; poderemos chamá-lo: "consciência coletiva" ou "comum". Sem dúvida, ela não tem por substrato um órgão único; é, por definição, difusa em toda extensão da sociedade.

${ }^{23}$ Aqui vale citar Boaventura de Sousa Santos que, sobre o potencial emancipatório dos Direitos Humanos e o processo de sua reconstrução intercultural afirma: Temos o direito a ser iguais quando a diferença nos inferioriza; temos o direito a ser diferentes quando a igualdade nos descaracteriza. (Cf. SANTOS, Boaventura de S. A Gramática do Tempo: para uma nova cultura política. 3. Ed. São Paulo: Cotez Editora, 2010. p. 462).

${ }^{24}$ Cf. ADORNO, Theodor. Indústria cultural e sociedade. Tradução de Julia Elizabeth Levy. 4.ed. São Paulo: Paz e Terra, 2007.
} 
permanecem reservados às decisões pautadas no sistema de referência de apenas uma cultura, qual seja, a ocidental.

Não há como forçar dois seres humanos ou duas culturas a alcançar o mesmo objetivo se um deles pretende concretizar apenas o seu objetivo particular. Dessa tentativa podem resultar duas hipóteses: 1- Nenhum dos dois conseguirá alcançar o objetivo pretendido, pois ambos sairão flagelados da luta; 2- O mais forte forçará o mais fraco a ajudá-lo na obtenção de seu interesse particular;

A primeira hipótese não costuma ser a mais corriqueira, sendo certo que a segunda amiúde emerge como consequiência das relações sociais interculturais dentro de um grupo/Estado e, muitas vezes, aparece travestida de democracia. Raimundo Panikar, em seu texto É a Noção dos Direitos Humanos em Conceito Ocidental? indaga: Será que uma democracia pode ser imposta e, apesar disso, permanecer democrática. ${ }^{25}$ Parece-nos que não.

A consideração do ser humano como uma entidade genérica fez com que a Organização da Unidade Africana adotasse, em 1981, a Carta Africana de Direitos Humanos e dos Povos (Carta de Banjul), que em seu preâmbulo consigna: Reconhecendo que, por um lado, os direitos fundamentais do ser humano se baseiam nos atributos da pessoa humana, o que justifica a sua proteção internacional, e que, por outro lado, a realidade e o respeito dos direitos dos povos devem necessariamente garantir os direitos humanos.

O sistema africano tem um ponto central: o deslocamento do foco no indivíduo para o foco no coletivo ao consignar o "respeito pelo direito dos povos". Esse deslocamento atinge um dos pontos nevrálgicos do sistema atualmente internacionalizado como paradigma de Direito, a noção de "sujeito de direito". Em muitos contextos a noção de "sujeito de direito" faria mais sentido se transmutada na noção de "sujeito de cultura", já que a compreensão coletiva do sujeito não se resume a sua compreensão abstrata, mas a sua compreensão inter-relacional. Ou seja, enquanto o "sujeito de direito" consubstancia um espectro de garantias de direitos a ele exclusivamente correspondentes (propriedade, vida, liberdade), o "sujeito de cultura" consubstancia um espectro de direitos correspondentes não a ele exclusivamente, mas a sua coletividade, como o direito à

\footnotetext{
${ }^{25}$ PANIKAR, Raimuno. É a Noção dos Direitos Humanos em Conceito Ocidental? DIÓGENES, Brasília. Editora $U N B, 1983, \mathrm{n}^{\circ} 5$. p. 20.
} 
personalidade jurídica coletiva de povos tradicionais, o direito à sobrevivência do grupo enquanto cultura (e não como mero folclore ou dado catalogado).

Como é evidente, uma das concepções de sujeito acima descritas não exclui os direitos correspondentes à outra, mas confere predominância a grupos de direitos distintos que, repita-se, ainda que não excludentes, podem assumir papel fundamental na própria integridade cultural dessas expressões do humano.

No âmbito nacional é interessante a tensão entre o Direito oficial e os povos indígenas. Do mesmo modo que no caso africano, a noção coletiva do sujeito de direito exige um novo paradigma para o próprio sistema jurídico. O conceito de Estado nacional (historicamente construído com bases iluministas gestadas na Revolução Francesa de 1789 e que até hoje orienta o modelo estatal ocidental), do mesmo modo, por si só já se mostra bastante problemático. ${ }^{26} \mathrm{~A}$ imposição forçada do Estado nacional num contexto pluriétnico não faz sentido, pois essa imposição, ao invés de garantir um diálogo entre culturas diversas, apenas verticaliza uma linguagem própria e exige a descaracterização cultural de quem pretende, ou precisa, dialogar com essa estrutura.

Um exemplo dessa inconsciência que atinge viciosamente a situação jurídica dos povos indígenas encontra-se no acesso à Justiça por meio de garantias constitucionais. O artigo $5^{\circ}$, inciso LXX, da Constituição Federal brasileira diz que somente poderão impetrar mandado de segurança coletivo os partidos políticos com representação no Congresso Nacional e organização sindical, entidade de classe ou associação constituída há pelo menos um ano. Por outro lado, o artigo 232 da Constituição diz: Os índios, suas comunidades e organizações são partes legítimas para ingressar em juizo em defesa de seus direitos e interesses, intervindo o Ministério Público em todos os atos do processo.

Ora, se a Constituição nada diz sobre a legitimidade ativa dos índios para a impetração de mandado de segurança coletivo, mas confere uma legitimidade claramente mais ampla ao permitir o ingresso em juízo para defesa de seus interesses, não restaria dúvida a respeito da possibilidade de se estender a capacidade jurídica para o mandado de segurança coletivo também aos representantes coletivos dos povos indígenas,

\footnotetext{
${ }^{26}$ Como escreve Pierre Clastres: Ele é, por essência, o emprego de uma força centrípeta que tende, quando as circunstâncias o exigem, a esmagar as forças centrífugas inversas. O Estado se quer e se proclama o centro da sociedade, o todo do corpo social, o mestre absoluto dos diversos órgãos desse corpo. Descobre-se assim, no núcleo mesmo da substância do Estado, a força atuante do Um, a vocação de recusa do múltiplo, o temor e o horror da diferença. Cf. CLASTRES, Pierre. Arqueologia da violência. Tradução de Paulo Neves. São Paulo: Cosac \& Naify, 2004. p. 87.
} 
ou seja, seus pajés ou caciques. No entanto, o Superior Tribunal de Justiça, em 2008, decidiu pela não admissão da referida legitimidade. ${ }^{27}$

Nota-se que, ainda que existam as condições formais para o reconhecimento jurídico de diferenças culturais, a indiferença diante da história e das peculiaridades culturais que permeiam as lutas dos povos indígenas pelo reconhecimento de suas particularidades étnicas é visível na decisão citada. Essa decisão, aliás, não apenas recusa reconhecimento da diversidade ao não reconhecer a representatividade coletiva do cacique, mas principalmente ao exigir que a comunidade indígena, para receber ouvidos do Estado, abandone suas formas culturais de representatividade e assuma as formas jurídicas impostas por entidades hegemônicas vinculadas ao sistema econômico que, hoje, determina a vida de todos os seres humanos e nada tem a ver com o modo de vida da cultura indígena.

A compreensão de que a humanidade não é uma poção homogênea decorrente de uma mágica racional-instrumental de imposição de vontades, mas, pelo contrário, um mosaico de formas humanas de estar no mundo, é fundamental para a sobrevivência da própria humanidade. As várias culturas representam diferentes experiências humanas que dão origem a diversos conhecimentos distintos, diversas formas de lidar com o mundo.

A respeito dessas experiências que ensejam conhecimentos diversos, o congolês Etienne-Richard Mbaya, professor da Universitat zu Koln, Alemanha, comenta que: É no aprofundamento das diversas experiências vividas em meio ao mundo que encontraremos as expressões da necessidade universal de criar o Homem livre e solidário. ${ }^{28}$ Esse comentário evidencia que o "universal" não deve ser retirado de pauta em favor de um relativismo que justifique barbáries fundamentalistas. Pelo contrário, ao colocar como universal a necessidade de se criar um homem livre e solidário, EtienneRichard Mbaya assume uma posição também assumida por Joaquín Herrera Flores no sentido de que: $O$ que negamos é considerar o universal como um ponto de partida ou um

\footnotetext{
${ }^{27}$ ADMINISTRATIVO. MANDADO DE SEGURANÇA. PORTARIA 2.656/2007. ILEGITIMIDADE DE PARTE. SUMULAS 101 E 262/STF. AUSÊNCIA DE COMPROVAÇÃO DE FERIMENTO A DIREITO LÍQUIDO E CERTO. 1- Não cabe mandado de segurança impetrado por cacique de etnia indígena contra ato normativo do Ministro da Saúde consistente na Portaria 2.656/2007 que estabelece diversas alterações no subsistema indigna de saúde. (...) (STJ - AgRg no MS 13248/DF - Min. Castro Meira. DJ 28/05/2008).

${ }_{28}$ MBAYA, Etienne-Richard. Gênese, evolução e universalidade dos direitos humanos frente à diversidade de culturas. Estudos Avançados, vol. 11, n. 30. Agosto de 1997. p. 17-41.
} 
campo de desencontros. Ao universal há que se chegar - universalismo de chegada ou de confluência - depois (não antes) de um processo conflitivo, discursivo de diálogo (....). ${ }^{29}$

A proteção desses espectros de conhecimento acumulado, de formas humanas de estar no mundo, emerge como uma ameaça para quem pretende ver assimilados ou mantidos seus costumes por outras culturas. É o que Boaventura de Sousa Santos $^{30}$ denomina localismos globalizados, noção que será retomada por nós no curso deste trabalho.

$\mathrm{Na}$ América Latina é evidente o fato de que a estrutura estatal e cultural instituída representa um obstáculo quase intransponível para a participação das comunidades indígenas na vida política e até mesmo social do país. Álvaro Garcia Linera, comentando sobre o caso específico da Bolívia, diz a esse respeito:

\begin{abstract}
A Bolívia se iniciou como república herdando a estrutura social colonial. A distribuição de terras, a estratificação social, o regime tributário e, inclusive, parte da administração pública e o pessoal encarregado de executá-la sofreu variações substanciais, deixando em pé o conjunto de classificação, poderes, instituições e pessoal hierárquico formado durante as diferentes etapas do regime colonial. E com ele, talvez o mais duradouro, o sistema de crenças, preconceitos e valores dominantes que haviam ordenado os comportamentos coletivos com anterioridade ao processo de independência: a racionalização das diferenças sociais através da invenção estatal do "índio" não só como categoria tributária, mas, antes de tudo, como o "outro negativo" (...). ${ }^{31}$
\end{abstract}

O processo de plasmar a humanidade por meio de uma generalização de cultura pode resultar na inexistência de saídas para problemas que futuramente forem impostos a essa mesma humanidade. A título de reflexão, cabe a seguinte indagação: Será que a visão ocidental do capitalismo seria mais benéfica, por exemplo, para o meio ambiente, do que a visão indígena? Respondendo a questão de forma bastante precisa, Eduardo C. B. Bittar comenta:

29 FLORES, Joaquin Herrera. Direitos Humanos, Interculturalidade e Racionalidade de Resistência. Sequência (UFSC), vol. 23, n. 44. 2002. ISSNe 2177-7055. p. 09 a 29.

${ }^{30}$ Cf. SANTOS, Boaventura de Sousa. A gramática do tempo: para uma nova cultura política. 3 . Ed. São Paulo: Cortez, 2010. p. 438.

${ }^{31}$ LINERA, Álvaro García. La potencia plebeya. CLACSO, Consejo Latinoamericano de Ciencias Sociales, Buenos Aires; PROMETEO libros, Buenos Aires. 2008. Tradução do original em espanhol: Bolivia se inició como república heredando la estructura social colonial. La distribución de tierras, la estratificación social, el régimen de tributos, e incluso parte de la administración pública y el personal encargado de ejecutarlo, no sufrió variaciones sustanciales, dejando en pie el conjunto de enclasamientos, poderes, instituciones y personal jerárquico formado durante las distintas etapas del régimen colonial. Y con ello, quizás lo más duradero, el sistema de creencias, prejuicios y valores dominantes que había ordenado los comportamientos colectivos con anterioridad al proceso independentista: la racialización de las diferencias sociales a través de la invención estatal del "indio", no sólo como categoría tributaria, sino, ante todo,como el "otro negativo" (...) (.p. 209) 
(...) Enquanto o saber tradicional dos povos indígenas retira sabedoria do seio da floresta, da observação da vida animal, organizando formas integradas de convívio com a natureza de modo ancestral, o homem moderno torna a natureza mero objeto precificável. (...) O sagrado da árvore é o sagrado daquilo que não posso criar e que é anterior a mim, daquilo que condiciona a possibilidade de mim e do outro, desse substrato fundamental e material da própria condição humana. ${ }^{32}$

A existência de uma só cultura no mundo pode ser vista como uma hipótese inviável para a sobrevivência da humanidade. Uma cultura poderia dialogar com outra cultura de modo a ter acesso, conhecimento de pontos de vista que não lhe foram proporcionados, seja pela sua situação histórica, como pela sua situação intersubjetiva, geográfica, política, religiosa, econômica, enfim, cultural. Ainda que esses pontos de vista do outro não sejam interessantes para uma ou outra expressão cultural, o fato do conhecimento nascido de um contato sensível e de diálogos prévios, e não de um olhar distante e virtual, pode assumir um papel relevante para o desenvolvimento de um momento político de respeito e convivência.

A proposta iluminista da razão pregou a ideia de um universalismo fundado em anseios de um único ego, o ocidental, tendo se difundido de forma exitosa pelo mundo, especialmente nas mais importantes instituições responsáveis pela tutela e promoção de direitos humanos. Essa proposta etnocêntrica de um universalismo particular que inicialmente não atentou para a diversidade das demandas políticas, sociais e culturais, teve suas raízes no projeto de um referencial filosófico que se convencionou chamar de Modernidade. Constituído sobre a já referida ideia iluminista de progresso e ordem, estes argumentos foram fundados em uma Razão que posteriormente se mostraria como um instrumento de dominação.

Situados principalmente no contexto político da Revolução Francesa de 1789, os fundamentos do iluminismo deram origem a termos novos que, lidos à luz dos movimentos revolucionários, assumiram e permanecem com conotações específicas, como é o caso do termo "nação", "poder constituinte", "soberania nacional” e "Estado". A esse respeito, Jürgen Habermas comenta: Como revela a designação "Nações Unidas”, hoje a sociedade mundial é constituída por Estados nacionais. O tipo histórico decorrente da Revolução Francesa e da Revolução Norte-americana impôs-se em todo o mundo. E essa circunstância não é nada trivial. ${ }^{33}$

\footnotetext{
${ }^{32}$ BITTAR, Eduardo C.B. O Direito na Pós-Modernidade. Ed. 2, revista, atualizada e ampliada. - Rio de Janeiro: Forense Universitária, 2009, p. 493.

${ }^{33}$ HABERMAS, J. A inclusão do outro. 3.ed. São Paulo: Loyola, 2007.p.127.
} 
Seguindo uma tradição doutrinária, poderíamos retornar à Lei das Doze Tábuas para pensarmos sobre os direitos humanos, mas não é esse o foco do nosso trabalho. A situação da noção de Direito (e também de direitos humanos) entre o momento revolucionário burguês de 1789 e os eventos mundiais conflagrados no século XX (guerras mundiais, genocídios e Guerra Fria) se mostra relevante não só por coincidir com a afirmação da Antropologia como área de conhecimento que tinham como foco exatamente o outro que pretendemos considerar na presente pesquisa. Ademais, dessa forma se facilita a compreensão conceitual de instituições essenciais para o debate que desenvolvemos aqui.

Conceitos como "Estado", "soberania", "sujeito de direito" etc., historicamente situadas entre o final do século XVIII até o século XX, dispensam maior delimitação conceitual, pois a ideologia iluminista e o culto à razão que caracterizaram esse período denominado Modernidade causaram impactos em todas as áreas, especialmente no desenvolvimento científico, na forma de se fazer ciência e nas instituições estudadas. A esse respeito, comenta Eduardo Bittar:

É permitido mesmo, ao termo modernidade, associar uma variedade de outros termos que, em seu conjunto, acabam por traçar as características semânticas que contornam as dificuldades de se definir modernidade. Esses termos são: progresso; ciência; razão; saber; técnica; ordem; soberania; controle; unidade; Estado; indústria; centralização; economia; acumulação; negócio; individualismo; liberalismo; universalismo; competição. Esses termos não estão aleatoriamente associados à idéia de moderno, pois nasceram com a modernidade e foram sustentados, em seu nascimento, por ideologias e práticas sociais nascentes e que se afirmam como uma espécie de sustentáculo dos novos tempos, saudados com muita efusividade pelas gerações ambiciosas pela sensação (hoje tida como ilusória) da liberdade prometida pela modernidade. ${ }^{34}$

As instituições responsáveis pela tutela e promoção de direitos humanos que inicialmente assumiram cegamente os discursos iluministas de uma razão única passaram por um processo crítico de reflexão acerca de sua própria legitimidade. Esse processo crítico desencadeou uma série de consequências no âmbito das ciências humanas, colocando em crise o universalismo, o positivismo jurídico e a própria filosofia da história. Zygmunt Bauman comenta:

O volume de "anormalidades", de "exceções à regra", tornava questionável a "norma" e a "regra" assumida de forma aberta ou tácita pelo discurso dominante que se referia a uma "modernidade". Se a vida moderna era de fato como a teoria aceita da modernidade me ensinara, então o que eu descobri sobre a realidade atual não era mais a "modernidade", e sim outra coisa. Mas o quê? $?^{35}$

\footnotetext{
${ }^{34}$ BITTAR, Eduardo C. B. O Direito na Pós-Modernidade. 2.ed.Rio de Janeiro: Forense Universitária, 2009.

35 BAUMAN, Zygmunt. Legisladores e Intérpretes: sobre modernidade, pós-modernidade e intelectuais. Trad. Renato Aguiar. Rio de Janeiro: Jorge Zahar Ed., 2010. P. 10.
} 
A Modernidade foi responsável pela criação daquilo que JeanFrançois Lyotard chamou de "grandes narrativas". 36 Essa passagem de Bauman deixa bastante clara a sensação de desconforto diante dessas narrativas, vistas como promessas que, uma vez não cumpridas, desencadearam um ambiente de crise. A crise gerada pelas incoerências das promessas da modernidade ensejaram novos discursos contrapostos a essas promessas, e esse momento de crítica e reflexão sobre a Modernidade recebeu de Lyotard a denominação "Pós-Modernidade".

O termo Pós-Modernidade nos parece interessante, pois é exatamente uma posição crítica em relação às grandes narrativas da Modernidade que pretendemos tencionar. Não obstante, vale comentar que Bauman preferiu o termo "modernidade líquida" (ainda que tenha usado o termo "pós-modernidade" até certo momento em sua produção teórica). ${ }^{37}$ Do mesmo modo, Dussel preferiu o termo "trans-modernidade". ${ }^{38}$

O que nos interessa, contudo, não é somente o fato de ser possível uma construção crítica sobre o que a Modernidade prometeu em termos de respeito às diferenças (a partir da noção de igualdade e fraternidade), mas o de também verificarmos na prática manifestações políticas de recusa dessas meta-narrativas em termos de direitos humanos, e os sistemas regionais de proteção de direitos humanos (interamericano, asiático, africano e islâmico) talvez tenham sido o grande exemplo de protesto contra o descaso universalizante e positivista gestado por esses projetos.

Os fundamentos da teoria crítica e sua aplicação ao Direito na pósmodernidade traz contribuições fundamentais para o nosso trabalho. A teoria crítica permite a colocação do Direito no tempo presente, contribui para a desconstrução das meta-narrativas que maculam os barbarizantes efeitos de uma única concepção de Direito e retira a concepção monumentalista do Direito. Ou seja, a concepção que vê no Direito uma beleza relacionada à tradição, compreendida como apego ao status quo. No texto seminal Teoria Crítica e Teoria Tradicional, essa forma de olhar para a realidade se encontra muito bem delineada nas seguintes passagens:

\footnotetext{
${ }^{36}$ Cf. LYOTARD, Jean-François. A Condição pós-moderna. São Paulo: José Olympio, 2010.

${ }^{37}$ Interessante explicação dessa trajetória terminológica é feita pelo próprio Bauman no prefácio à obra citada Legisladores e Intérpretes, na edição brasileira da editora Zahar.

${ }^{38}$ Cf. DUSSEL, Enrique. Transmodernidad e Interculturalidad (Interpretación desde la Filosofia de la Libertación). UAM-Iz, Cidade do México, 2005. Também disponível em: <http://pt.scribd.com/doc/56989586/TRANSMODERNIDAD-e-interculturalidad> Acesso em 24/10/2011.
} 
$\mathrm{Na}$ medida em que o conceito da teoria é independentizado, como que saindo da essência interna da gnose (Erkanninis), ou possuindo uma fundamentação ahistórica, ele se transforma em uma categoria coisificada (verdinglichte) e, por isso, ideológica.

(...)

Em regra geral o indivíduo aceita naturalmente como preestabelecidas as determinações básicas de sua existência e se esforça para preenchê-las. (...) A separação entre indivíduo e sociedade, em virtude da qual os indivíduos aceitam como naturais as barreiras que são impostas às suas atividades, é eliminada na teoria crítica, na medida em que ela considera ser o contexto condicionado pela cega atuação conjunta das atividades isoladas, isto é, pela divisão dada do trabalho e pelas diferenças de classe, como uma função que advém da ação humana e que poderia estar possivelmente subordinada à decisão planificada e a objetivos racionais.

(...)

Alterações no sistema, seja a introdução de novos gêneros, seja outra qualquer, não são concebidas costumeiramente no sentido de que as determinações são necessariamente rígidas e por isso inadequadas. Nem tampouco as alterações do sistema são concebidas como resultado da alteração da relação com o objeto ou mesmo dentro do próprio objeto, sem que este perca sua identidade. Ao contrário, as alterações são tomadas como uma falha do nosso conhecimento anterior ou como substituição de partes isoladas do objeto por outras (...). ${ }^{39}$

\section{Marcos Nobre explica que:}

Desde seu marco inaugural, com a obra de Karl Marx (1818-1883), a Teoria Crítica se caracteriza por polemizar com duas maneiras tradicionais de compreensão da sociedade: o pensamento chamado de utópico e aquele que, com uma pretensão de neutralidade e objetividade, propõe-se unicamente a descrever o funcionamento do capitalismo. No caso de Marx, esses dois principais adversários teóricos são representados pelos "socialistas utópicos" e pela "economia política". 40

O que interessa nessa explicação de Marcos Nobre é que existem várias correntes que, dentro dessas preocupações centrais, trabalham a realidade (o tempo presente) de forma crítica, levando em conta as preocupações que orientaram os estudos de Karl Marx e, também, de Sigmund Freud. Essa multiplicidade de correntes dentro da teoria crítica explica-se pela própria dinâmica do tempo presente, e isso fica esclarecido na seguinte passagem de Marcos Nobre:

A Teoria Crítica não pretende apresentar uma "explicação mais adequada" do funcionamento do capitalismo. Pretende entender o tempo presente em vista da superação de sua lógica de dominação. Daí o seu caráter crítico justamente: "entender" como "as coisas funcionam" é já aceitar que essas "coisas" são assim e que não podem ser radicalmente de outra maneira.

Por essa razão, é importante enfatizar que a Teoria Crítica não se coloca como "concorrente" das contribuições não-críticas. (...)

Não cabe à teoria limitar-se a dizer com as coisas funcionam, mas sim analisar o funcionamento concreto das coisas à luz de uma emancipação ao mesmo tempo concretamente possível e bloqueada pelas relações sociais vigentes. Com isso, é a

\footnotetext{
${ }^{39}$ HORKHEIMER, Max. Teoria Crítica e Teoria Tradicional. (1937). In. Textos Escolhidos - Benjamin, Horkheimer, Adorno, Habermas. (Coleção "Os Pensadores”). São Paulo: Abril, 1980.

${ }^{40}$ NOBRE, Marcos (org). Curso livre de Teoria Crítica. Campinas-SP: Papirus, 2008. p. 17.
} 
própria perspectiva da emancipação que torna possível a teoria, pois é essa perspectiva que abre pela primeira vez o caminho para a efetiva compreensão das relações sociais.

(...)

É uma característica marcante da Teoria Crítica a sua permanente renovação, a sua permanente capacidade de analisar o momento histórico presente. Nesse sentido, quem quer que continue a repetir hoje como verdade inabalável o diagnóstico de Marx, por exemplo, deixa de ser crítico, pois o essencial é que seja capaz de produzir novos diagnósticos do tempo da perspectiva teórica e prática inaugural de Marx. Repetir como verdade o que Marx ou qualquer teórico crítico do passado afirmaram é cair no dogmatismo que a Teoria Crítica busca a todo custo evitar. ${ }^{41}$

No campo do Direito, rompimento com a sua compreensão fatalista, do Direito entendido como um produto científico de um processo de positivação de fatos naturais, é um passo fundamental. As ciências humanas não podem ser compreendidas de forma estática, nem compartimentada, e é por essa razão que a análise da situação jurídica da etnicidade exige uma compreensão mais alargada das questões políticas, filosóficas e antropológicas que impactaram o Direito para que ele se configurasse da maneira como hoje está configurado. Novamente citando Horkheimer: É preciso passar para uma concepção que elimine a parcialidade que resulta necessariamente do fato de retirar os processos parciais da totalidade da "práxis" social. ${ }^{42}$

Antonio Carlos Wolkmer, explicando o desenvolvimento da Teoria Crítica e sua aplicação ao Direito, comenta:

Fica claro, por conseguinte, que, enquanto a ideia de consciência e de razão na teoria tradicional está vinculada ao mundo da natureza e ao presente em contemplação, a teoria crítica expressa a ideia de razão vinculada ao processo histórico-social e à superação de uma realidade em constante transformação.

(...)

A estratégia discursiva não nega a "aparência real" do fenômeno jurídico, mas, sobretudo, procura revelar os interesses e as contradições que se ocultam por trás de uma estrutura normativa. A crítica legitima-se ao ser competente em distinguir, na esfera jurídica, o "nível das aparências" (realidade normativa da "realidade subjacente" (o sublinear, o que não está prescrito mas existe). ${ }^{43}$

A compreensão do todo proposta pela teoria crítica é uma compreensão da realidade em situação, e não da realidade abstraída. A proposta de compreensão do tempo presente de forma conglobante não exclui a consideração das diferenças que, e isso é fato, é tão real quanto qualquer realidade presente.

\footnotetext{
${ }^{41}$ Op. cit. p. $17-18$.

${ }^{42}$ Op. Cit. p.38.

${ }^{43}$ WOLKMER, Antônio Carlos. Introdução ao Pensamento Jurídico Crítico. Ed.5. São Paulo: Saraiva, 2006. p.7 e 19 .
} 
Os direitos humanos e a legitimidade das instituições responsáveis pela sua promoção passaram por um processo de rediscussão, buscando a compreensão da pluralidade que constitui a humanidade. Com o presente trabalho pretendemos, a partir dessas discussões, analisar a situação jurídica atual dos povos indígenas no Brasil e propor uma linha de reflexão que possibilite a inclusão participativa desses povos na vida política nacional através de um processo intercultural de diálogo sem que o Direito sirva de justificativa legítima para a repressão violenta dessa "luta por reconhecimento". ${ }^{4}$

\footnotetext{
${ }^{44}$ Trabalharemos a noção de "luta por reconhecimento" a partir da teoria de Axel Honneth, em especial sua obra Luta por reconhecimento: a gramática moral dos conflitos sociais. 2.ed. São Paulo: Ed. 34, 2009. Para esclarecer as três dimensões do reconhecimento para Honneth, vale anotar: São três as dimensões do reconhecimento. As relações primárias, ligadas à experiência do "amor" e da "amizade", fazem parte da esfera emotiva. Tal esfera permite ao indivíduo desenvolver uma confiança em si mesmo, indispensável para seus projetos de auto-realização. A segunda dimensão do reconhecimento abrange as relações jurídicas próprias do campo do "direito". Essa esfera jurídico-moral assegura aqueles direitos que permitem que a pessoa seja reconhecida como autônoma e moralmente imputável, possibilitando assim o desenvolvimento dos sentimentos de auto-respeito. Na comunidade de valores, por fim, residirá a terceira dimensão do reconhecimento, que Honneth compreende como uma dimensão da "solidariedade" social. Para além da autoconfiança e do sentimento de auto-respeito, essa dimensão abrange a esfera da estima social, em que os projetos de realização pessoal podem ser objeto de um respeito solidário numa comunidade de valores. (Cf. WERLE, Denilson L. e MELO, Rúrion S. Reconhecimento e Justiça na Teoria Crítica da Sociedade em Axel Honneth. In. NOBRE, Marcos (org). Curso livre de Teoria Crítica. Campinas-SP: Papirus, 2008. p. 183-198.)
} 


\section{CAPÍTULO 2 \\ PLURALIDADE CULTURAL: A PROPOSTA DA INTERCULTURALIDADE}

\section{1- CONTRIBUIÇÕES DA ANTROPOLOGIA AO DIREITO}

Considerando que o presente trabalho tem a finalidade de propor linhas de reflexão acerca dos fatores que deveriam ser considerados para a proposta de diálogo intercultural como processo de atribuição de sentido ao Direito, cabe explicitar o que entendemos por cultura. Tal compreensão é relevante para contextos pluriculturais e, nesse particular, as experiências que a Antropologia teve no seu contato com o outro estranho é fundamental para pensarmos o Direito. Ana Lúcia Pastore explica que o Direito e a Antropologia tiverem dois momentos importantes de contato no Brasil, quais sejam, na virada do século XIX para o século XX e no período de redemocratização política (anos 1980), comentando que no segundo momento, o Direito passou a ser objeto de análise da Antropologia.

(...) Esta, sem dúvida, foi uma das marcas do segundo encontro da antropologia com o direito, encontro, portanto, bastante diferente do primeiro, pois foi mais uma busca da antropologia pelo direito, enquanto objeto de estudo, do que uma busca do direito pela antropologia enquanto área do conhecimento apta a lhe fornecer subsídios teóricos e empíricos. ${ }^{45}$

Eis o que pretendemos realizar neste tópico, ou seja, um olhar antropológico sobre o Direito como fato a ser considerado em nossa proposta de interculturalidade, sem, contudo, deixar de analisar as consequências do primeiro momento, ou seja, quando o Direito buscava na Antropologia subsídios empíricos. Para esclarecer, vale citar comentário sobre esse tema feito por Marco Antônio Barbosa:

Sabemos igualmente que são relações assimétricas, de dominação da sociedade
brasileira sobre as sociedades indígenas, tendo isso várias consequiências nas relações
jurídicas e nos direitos (brasileiro e indígena) além de outras. Ademais disso, o próprio
direito brasileiro, como de resto a teoria geral do direito formulada sob a inspiração
quase que exclusiva do direito ocidental, trata os direitos dos povos tradicionais de

45 SCHRITZMEYER, Ana Lúcia Pastore. O ensino da antropologia jurídica e a pesquisa em direitos humanos. in Nalini, José Renato e Carlini, Angélica Luciá (org.). Formação Jurídica e Direitos Humanos. Rio de Janeiro: Forense, 2010. 
maneira pouco ou nada comparativa e diversificada, privilegiando o direito e a cultura ocidentais, como únicos prismas para se observar o Direito e o mundo. ${ }^{46}$

Pensar como o Direito (oficial) lida com o outro estranho, como o Direito reproduz preconceitos, será o foco do presente tópico que será complementado pelo tópico seguinte, especialmente no que diz respeito à noção de Direito enquanto um instrumento que pode ser tanto de liberdade como de opressão. A esse respeito, Tércio Sampaio Ferraz Jr. comenta: Ser livre é estar no direito e, no entanto, o direito também nos oprime e tira-nos a liberdade. ${ }^{47}$

Nessa linha, inicialmente analisaremos como a forma de abordagem que a Antropologia fez da figura do outro nos séculos XIX e XX influenciou a sistematização do Direito enquanto ciência até os dias de hoje. Essa primeira análise terá a finalidade de esclarecer alguns dos motivos pelos quais o outro ainda encontra, no Direito, sérios obstáculos para o seu pleno reconhecimento.

A abordagem do tema exige a análise do termo "etnocentrismo", que é muito caro às considerações que pretendemos tecer e que, se não delimitado de forma razoável, poderá levar a discussões que não interessam diretamente à nossa preocupação central: uma proposta de experiência intercultural a partir da expansividade proporcionada pelo contato entre diferentes.

A ideia de etnia normalmente não nos proporciona uma compreensão reflexiva, mas sim projetada, nos remetendo, amiúde, à imagem de comunidades tribais. Quando conversamos entre acadêmicos de Direito ninguém se reconhece como pertencente a um grupo étnico. Grupos étnicos, para nós, ocidentais, são comunidades indígenas, comunidades africanas, ciganas, etc. Isso se dá em razão de um aspecto bastante interessante da experiência intercultural, que é a dimensão egocêntrica do contato interétnico. Ou seja, o ponto de distinção está sempre no outro, nunca em mim, que inconscientemente me tomo como paradigma das minhas próprias investigações.

$\mathrm{Na}$ posição da modernidade, sempre que estamos diante do outro, portanto, o nosso olhar é lançado a ele com objetivos de identificação de traços familiares. Em outras palavras, sempre que nos deparamos com indivíduos de culturas distintas da nossa procuramos encontrar neles e em suas culturas traços, vestígios, resquícios das

\footnotetext{
${ }^{46}$ BARBOSA, Marco Antonio. Direito Antropológico e terras indígenas no Brasil. São Paulo: Pleiade, 2001. p. 34. A respeito da relação entre Antropologia e Direito, conferir também: LIMA, Roberto Kant de. Ensaios de Antropologia e de Direito.Rio de Janeiro: Lumen Juris, 2008.

${ }^{47}$ FERRAZ JR., Tércio Sampaio. Introdução ao Estudo do Direito: técnica, decisão, dominação. Ed. 6. São Paulo: Atlas, 2011. p.1.
} 
instituições que encontramos na nossa própria cultura e subjetividade. Só por meio dessa compreensão equivocada, aliás, que os universalismos puderam se justificar.

A história da Antropologia mostra que os métodos de pesquisa antropológica incorreram, inicialmente, nesse "vício de subjetividade narcísica". Os primeiros antropólogos que foram a campo para estudar o outro buscavam encontrar uma família, um governo, uma estrutura estatal, um sistema de julgamento de desvios sociais, uma forma de educação, um sistema linguístico com uma mesma base estrutural, ${ }^{48}$ sempre $^{2}$ levando em suas mochilas a expectativa de encontrar nessas culturas, no máximo, meras variações dos modelos típicos da cultura ocidental que lhes era "de berço". Acontece que a Antropologia teve de se abrir para o fato empírico de que muitas dessas instituições nem mesmo existiam em outras culturas; em verdade, nem mesmo faziam sentido para essas culturas e que, do mesmo modo, outras estruturas que existiam nessas sociedades não pertenciam e não faziam sentido para a cultura ocidental.

Nessa linha, parece-nos importante pensar acerca da compreensão jurídica da etnicidade, procurando entender como o Direito vê o outro e por que motivo regula, reprimindo-o e oprimindo-o. Para isso, precisaremos transpor algumas questões prévias, intimamente ligadas à necessidade de fixação de marcos semânticos. Inicialmente, precisamos pensar a respeito de quem é esse outro de quem estamos falando e, depois, analisar o que é etnia e a que nos referimos quando falamos em "cultura", para o fim de pensarmos interculturalidade.

A importância de se questionar como o Direito vê o outro assume relevância central se considerada como correta a definição que Richard Potz e René Kuppe adotam em relação à organização do sistema jurídico: A organização do sistema jurídico se fundamenta na concepção que esse sistema tem do ser humano. ${ }^{49}$

As implicações dessa definição nos guiam à conclusão de que todo sistema jurídico se apresenta como um sistema simbólico e discursivo sobre o ser humano, verbalizando um conjunto de interesses e expectativas jurídicas do grupo que o elaborou em relação a esse ser humano considerado. Nesse sentido, na medida em que todo ser humano verbaliza a ideia que tem de si mesmo, toda pretensão de elaborar um sistema

\footnotetext{
48 Daniel Everett, professor do Department of Languages, Literature, and Cultures at Illinois State University, colocou em xeque a teoria de Chomsky ao encontrar na língua dos Pirahã da Amazônia características como ausência de termos fixos para cores e tempos verbais imperfeitos. Cf. EVERETT, Daniel. Don't Sleep, There Are Snakes: Life And Language In The Amazonian Jungle. Ed.1. Panthenon Books, 2008.

${ }^{49}$ KUPPE, R. \& POTZ, R. La Antropología del Derecho: perspectivas de su pasado, presente y futuro. In. Antropología Jurídica. Editora da Universidad Nacional Autónoma de Mexico: México, 1995. p.9.
} 
jurídico que não trate de considerar o fato do etnocentrismo antes de sua construção e durante sua realização hermenêutica será problemática, pois ensejará um sistema jurídico também etnocêntrico.

Nesse sentido, e desde já, podemos chamar a atenção para o que será melhor desenvolvido adiante, ou seja, o fato de que para a superação do etnocentrismo com reflexos no Direito é essencial a consideração das dimensões psicanalíticas das relações interétnicas na Política. Relação discursiva esta que reflete no sentido do Direito, podemos, discutir os termos do diálogo intercultural que, dialeticamente, e enquanto processo, proporcionará uma superação do centralismo étnico totalitário que, hoje, é responsável pela exclusão de parcela considerável da humanidade dos espaços que se entendem como democráticos.

A ideia do outro compreendida dentro de um debate político e jurídico não é muito comum, pois tanto a Política como o Direito não costumam se preocupar com o outro que, no final das contas, carrega consigo a carga da heterogeneidade. Sendo o Direito e a Política (ocidental e etnocentricamente compreendida) ${ }^{50}$ duas vias de homogeneização social, de criação da ideia durkheimniana de "coesão social", o outro será sempre alguém destoante, diferente, com objetivos distintos e, portanto, problemático. Essa característica inicialmente destoante acaba por inserir o outro numa condição de obstáculo à idéia de coesão social e, normalmente, também na condição de inimigo.

A repulsa pela diferença estetizada no outro não é um fato recente na história da humanidade. Heródoto, que viveu em 484-424 a. C., citado por Roque de Barros Laraia, afirmou: Se oferecêssemos aos homens a escolha de todos os costumes do mundo, aqueles que lhes parecessem melhores, eles examinariam a totalidade e acabariam preferindo os seus próprios costumes, tão convencidos estão de que estes são melhores do que todos os outros. ${ }^{51}$

Roque Laraia também explica essa repulsa pelo outro "estranho" na seguinte passagem:

A atitude mais antiga, e que se baseia indiscutivelmente em fundamentos psicológicos sólidos (já que tende a reaparecer em cada um de nós quando nos encontramos numa situação inesperada), consiste em repudiar pura e simplesmente

\footnotetext{
50 Apenas para retratarmos uma concepção que nos parece preocupante, pois excludente, mas cientes da dimensão e completude da obra desse autor, que não será por nós analisada, citamos Weber: Por mais que a vida tenha um sentido, só conhece o combate eterno que os deuses travam entre si, ou, evitando a metáfora, só conhece a incompatibilidade dos pontos de vista últimos possíveis, a impossibilidade de regular os seus conflitos e, portanto, a necessidade de se decidir a favor de um ou de outro. (WEBER, Max - A objetividade do conhecimento na ciência política e social - 1904).

${ }^{51}$ LARAIA, Roque de Barros. Cultura - um conceito antropológico. $15^{\circ}$ ed. Rio de Janeiro: Jorge Zahar Editora, 2002. p. 110.
} 
as forças culturais, morais, religiosas, sociais, estéticas, que são as mais afastadas daquelas com as quais nos identificamos. "Hábitos de selvagens", "na minha terra é diferente", "não se deveria permitir isto", etc., tantas reações grosseiras que traduzem esse mesmo calafrio, essa mesma repulsa diante de maneiras de viver, ver ou pensar que nos são estranhas. ${ }^{52}$

Essa pré-disposição para repudiar culturas diferentes, considerando-as como primitivas ou atrasadas, acabou por legitimar algumas intervenções do Ocidente em outras culturas sob o pretexto de colaborar para o desenvolvimento de todas elas. No entanto, essa concepção superficial de progresso, fundada na tendência de analisar sociedades humanas com base em premissas darwinistas, corroborou para que, até hoje, os seres humanos não tenham logrado falar de direitos humanos e alcançar um consenso. Lamentavelmente, os assentos políticos, os bancos acadêmicos, as doutrinas religiosas e praticamente todas as mais importantes instituições responsáveis pela formação da ideologia social, estão repletas de cérebros referenciais, que ainda não perceberam que, como afirmou Gofredo Telles Jr., em sua obra Direito Quântico:

Cada ser humano possui seu próprio universo cognitivo, isto é, possui um conjunto ordenado de conhecimentos, uma estrutura cultural, que é seu próprio sistema de referência, em razão do qual atribui a sua significação às realidades do mundo.

Toda realidade pode ser objeto de conhecimento. Mas o conhecimento de uma realidade está sempre condicionado pelo sistema de referência do sujeito conhecedor. $^{53}$

Clifford Geertz diz que (...) os homens nascem com um equipamento para viver mil vidas, mas terminam vivendo uma só, ${ }^{54}$ qual seja, aquela vida imposta pela própria cultura, que atua como uma lente situada entre o indivíduo, seu inconsciente e a realidade social. É possível notarmos, então, que o sistema de referência cultural do sujeito é elemento determinante do processo cognitivo, logo, determinante de todas as obras humanas. Sendo o Direito - na condição de sistema discursivo - também resultado de um sistema de referências, com igual razão sua interpretação será pautada nesse sistema, residindo aqui uma questão central da presente pesquisa, vez que somente haverá identidade de determinada cultura com determinado sistema normativo na medida em que este sistema representar um conjunto de discursos veiculadores da identidade dessa cultura

\footnotetext{
${ }^{52}$ Op. cit. p. 333

53 TELLES-JR., Gofredo. Direito Quântico - Ensaio Sobre o Fundamento da Ordem Jurídica. $7^{\circ}$ ed. São Paulo: Juarez de Oliveira LTDA, 2003. p. 217.

${ }^{54}$ GEERTZ, Clifford. A Interpretação das Culturas. Rio de Janeiro: LTD, 1989. p.57.
} 
ou, em outros termos, um sistema de normas que possibilite a expansividade humana típica de cada cultura.

Por esse motivo, é bastante complicado falar em Direito Universal quando estão em debate questões relativas à liberdade, à religião, aos costumes. As questões relacionadas ao Direito enquanto linguagem e as implicações dessa compreensão para a hermenêutica intercultural serão abordadas no próximo tópico, importando agora a verificação da relação entre Antropologia e Direito.

O outro, na linha argumentativa que desenvolvemos aqui, pode ser compreendido desde a figura do índio da época das missões colonizadoras, do negro contatado na África e escravizado sob o argumento de não possuir alma, até a figura do estrangeiro e todos os sujeitos de cultura que ainda são o destino do dedo indicador do Ocidente nas questões que envolvem direito à liberdade e à vida no cenário internacional.

O outro a que nos referimos, portanto, é o indivíduo ou a coletividade que, por destoar das práticas culturais do Ocidente, causam aos ocidentais uma experiência de estranhamento e de desejo de homogeneização tópica narcísica. Por homogeneização tópica narcísica queremos tratar o assimilacionismo, que, como se verá mais adiante, foi a pretensão institucionalizada no nosso Direito de transformar o outro diferente em nós mesmos através de um recurso tópico ${ }^{55}$ à cultura ocidental. $\mathrm{O}$ assimilacionismo partia do pressuposto de que nossa cultura poderia ser compreendida como a referência mais razoável para se viver no mundo.

Quando dizemos que o Direito verbaliza um conjunto de interesses e expectativas jurídicas em forma de discursos do grupo que o elaborou com base em uma determinada concepção ser humano, queremos chamar atenção ao fato de que se esse grupo que elabora o Direito não for essencialmente pluricultural, a forma de consideração do ser humano será etnocêntrica e, portanto, excludente, por consequência. A compreensão do ser humano para fins de criação do Direito será responsável pela possibilidade ou não de se pensar diálogo intercultural a partir do Direito, pois só uma compreensão intercultural do ser humano ensejará um sentido de Direito também intercultural e, consequentemente, de reprodução da interculturalidade a partir desse sistema.

\footnotetext{
55 Tópico adj. (...) 4.(1721) RET diz-se dos lugares-comuns ou o estudo ou tratado acerca dos mesmos (...) 11 lugares-comuns. (Dicionário Houaiss da língua portuguesa). Cf. ainda, sobre o conceito de topoi, Boaventura de Sousa Santos: lugares comuns retóricos mais abrangentes de determinada cultura. Funcionam como premissas de argumentação que, por não se discutirem, dada a sua evidência, tornam possível a produção e a troca de argumentos. (in Por uma Concepção Multicultural de Direitos Humanos. Artigo em LADSLAU-BIANCO, Bela \& Capinha, Graça (organizadores). Identidades: estudos de cultura e poder. São Paulo: Hucitec, 2000. p.30).
} 
Se compreendido como instância genérica, abstrata, a compreensão jurídica desse ser humano terá como resultado um sistema de Direito etnicamente centralizado. Distintamente, se compreendido de forma situada, histórica, específica e política, o ambiente para pensarmos a interculturalidade estará consolidado, remanescendo a tarefa apenas de pensarmos o processo para a realização desse diálogo, que será objeto do próximo capítulo.

A busca por uma definição de "etnia" e "cultura", parafraseando Manuela Carneiro da Cunha, já foi responsável pela derrubada de árvores demais. Certamente, a definição desses termos enfrenta de início um obstáculo epistemológico, na medida em que definir cultura seria uma atividade metalinguística reflexiva, ou seja, um esforço para se definir um discurso por meio dos conceitos típicos desse próprio discurso. Não nos interessa esse detalhe particularmente, mas vale a pena considerar que é exatamente em razão da verificação de uma metalinguagem reflexiva na busca pela definição de cultura que, sem a pretensão de coerência, mas apenas de completude (como afirmou a própria autora), Manuela Carneiro da Cunha estabelece uma distinção entre cultura e "cultura" (com aspas). Para a antropóloga, a consideração da reflexividade da cultura importa a conciliação de paradoxos interétnicos que, ao invés de se excluírem, podem coexistir num espaço intercultural. ${ }^{56}$

$\mathrm{Na}$ linha do propósito do presente trabalho, propomos uma definição didática dos conceitos de "etnia" e "cultura" a partir dos trabalhos de Manuela Carneiro da Cunha. Iniciaremos com a proposta de definição do termo cultura, recorrendo à referência feita pela autora à definição proposta por Lionel Trilling:

(...) um complexo unitário de pressupostos, modos de pensamento, hábitos e estilos que interagem entre si, conectados por caminhos secretos e explícitos com os arranjos práticos de uma sociedade, e que, por não aflorarem à consciência, não encontram resistência à sua influência sobre as mentes dos homes. ${ }^{57}$

É interessante a noção de "complexo unitário de pressupostos", na medida em que essa ideia fixa a concepção de cultura como um sistema de referências relativo aos juízos dos seres humanos, esclarecendo a explicação de Heródoto citada no início deste tópico. Além disso, essa definição de cultura evidencia a insuficiência de clareza de alguns conceitos constantes dos textos normativos, como é o caso do conceito de cultura existente no artigo 4 da Convenção sobre a Proteção e Promoção da

\footnotetext{
${ }^{56}$ Cf. CARNEIRO DA CUNHA, Manuela. Cultura com aspas e outros ensaios. São Paulo: Cosacnaif, 2009. p. 235-387.

57 TRILLING, Lionel, apud CARNEIRO DA CUNHA, Manuela, Op. Cit. p. 357.
} 
Diversidade das Expressões Culturais de 2005 (internalizada no ordenamento jurídico brasileiro pelo Decreto Legislativo 485/2006), ou seja: “Conteúdo cultural” refere-se ao caráter simbólico, dimensão artística e valores culturais que têm por origem ou expressam identidades culturais. (grifamos)

Além de considerar cultura como algo muito mais abrangente do que um conteúdo de caráter simbólico e artístico, Manuela Carneiro da Cunha, citando Trilling analisa ainda a cultura como uma categoria que pressupõe o inconsciente e que está em permanente reajuste e ressignificação. É exatamente nessa linha dialética (ou diacrítica, como proposto por Manuela) que a antropóloga propõe etnicidade como um veículo de organização política que, apesar de não se confundir com a cultura em si, se dá em relação a ela. Mais que isso, a etnicidade seria uma forma política de linguagem organizadora de movimentos de oposições interétnicas que, em razão mesmo dessas oposições, seria transformadora e responsável pela permanente ressignificação da cultura.

\footnotetext{
Recapitularei um pouco - não será inútil - o que andei dizendo. Tentei mostrar que a etnicidade pode ser mais bem entendida se vista em situação, como uma forma e organização política: essa perspectiva tem sido muito fecunda e tem levado a considerar a cultura como algo constantemente reelaborado, despojando-se então esse conceito do peso constituinte de que já foi revestido. Mas essa perspectiva acarreta também que a etnicidade não difere, do ponto de vista organizatório, de outras formas de definição de grupos, tais como grupos religiosos ou de parentesco. Difere, isto sim, na retórica usada para se demarcar o grupo, nesses casos uma assunção de fé ou de genealogias compartilhadas, enquanto na etnicidade se invocam uma origem e uma cultura comuns. ${ }^{58}$
}

O que interessa de fato para a presente pesquisa na definição sugerida por Manuela Carneiro da Cunha é que, vista pela lente da natureza política da etnicidade, a cultura é uma categoria em movimento, permanentemente reinventada. Além disso, sendo definida como veículo organizatório, e tendo que a etnicidade pode ser a armação interna das relações de produção, ${ }^{59}$ o próprio modo de produção capitalista pode ser compreendido como uma expressão de etnicidade dentro da cultura ocidental e em oposição a tantas outras etnicidades ocidentais. Compreendido enquanto movimento étnico, o capitalismo ocidental atual e suas principais consequências (sociedade de consumo, volatilidade de capitais, concentração de riquezas) pode ser legitimamente alocado em um dos polos das relações dialéticas interétnicas, saindo da condição retórica de papel de fundo (como se fosse um fato natural, fatal e supremo) e assumindo a condição de interlocutor do pretendido diálogo intercultural.

\footnotetext{
${ }^{58}$ Op. Cit. P.244.

${ }^{59}$ OP. Cit. P. 243.
} 
Para os fins deste trabalho o papel de fundo cabe, então, à semântica dos direitos humanos que, interculturalmente estabelecida, proporciona, nos termos colocados, a reflexão e a construção de um momento posterior ao atual onde a Política e o Direito oficial sejam espaços abertos para o diálogo entre culturas. Estas, permanentemente reformuladas e atualizadas em razão de suas dinâmicas interétnicas, poderão conviver e firmar permanentes consensos (estes também dinâmicos, históricos e superáveis).

Assim, quando propomos a interculturalidade, propomos um espaço de diálogos e trocas culturais permanentemente ressignificados, admitidos e abandonados pelos constantes e dinâmicos reajustes interétnicos. Nos termos deste trabalho, quando nos valermos do termo etnocentrismo, estaremos fazendo referência expressa a uma forma ocidental de lidar com outras culturas (ou outras etnias - aqui essa precisão não importa), qual seja, a forma colonizadora de dialogar com o outro.

A superação do etnocentrismo, portanto, exige uma compreensão crítica do tempo presente, de modo a situar cada realidade étnica no seu devido lugar político da cena dialógica pretendida. As aventuras empreendidas pela cultura iluminista que foi responsável pelo culto da razão e pela "naturalização" das ciências humanas não conseguiu se manter firme na retórica que pretendeu utilizar para a emancipação do homem.

Nesse sentido, para que possamos empreender uma análise completa e humana do etnocentrismo e suas implicações jurídicas, é necessária inicialmente, a superação da teoria tradicional cartesiana. Essa é uma questão prévia referente ao método de análise. Por essa razão, a análise crítica que compreenda a totalidade dos problemas, incluindo as negatividades dos discursos (pretensamente) afirmativos de direitos se mostra como uma saída ao método tradicional, que teoriza propostas de reajustes sociais a partir de considerações simplistas de efeitos operantes no mundo da vida que, ao nosso modo de ver, consideram as causas como simples fatalidades desvinculadas da história e da vontade política de quem detém o poder.

A análise das correntes antropológicas desenvolvidas no século XIX e XX e a utilização que o Direito oficial fez dos resultados desses estudos para a sua configuração enquanto ciência encadearão as premissas para a conclusão de que, para que seja possível a entrada do Direito em diálogo intercultural, será necessária a desconstrução crítica dos argumentos utilizados pelo Direito atual. Este por sua vez, encontra-se globalizado e instituído como parâmetro de segurança universal para a imposição de um 
modelo de democracia que, em muitos casos (como na América Latina e, especificamente, no Brasil), acaba por se configurar como autoritarismo etnocêntrico.

Essa análise crítica do Direito que hoje serve de parâmetro globalizado de segurança universal deve levar em conta os discursos políticos que legitimaram a institucionalização de um único sistema como modelo universal de Direito, bem como as manifestações pluriculturais de contrariedade a essa institucionalização e à má politização dos direitos humanos, nos termos desenvolvidos no primeiro capítulo deste trabalho.

A relação do Direito com o outro tem íntima ligação com as correntes antropológicas desenvolvidas no século XIX e XX. Analisaremos essas correntes e a sua influência no Direito a partir de dois textos especialmente, quais sejam, A Falsa Medida do Homem, ${ }^{60} \mathrm{de}$ Stephen Jay Gould, e La Antropología del Derecho: perspectivas de su pasado, presente y futuro, ${ }^{61}$ de René Kuppe e Richard Potz.

Na obra A Falsa Medida do Homem, no texto Negros e índios como espécies separadas e inferiores, Stephen Jay Gould além de analisar as características do determinismo biológico enquanto corrente científica, propõe um foco de abordagem que nos parece fundamental tanto para a compreensão dos problemas metodológicos da abordagem racista da diversidade como para a crítica às conclusões dessas correntes, na linha que desenvolvemos na presente dissertação.

Stephen Gould propõe afastar a ideia de que a ciência indutiva teria fornecido dados legítimos para fortalecer o argumento da hierarquização racial e assumir que essa hierarquização foi uma opção a priori que acabou por determinar as questões "científicas" e também os dados reunidos. Essa ideia de uma ciência que parte de um conceito a priori é extremamente importante não apenas pelas consequências que induz, mas principalmente por colocar em xeque toda a ideologia da época que pregava uma ciência pura, pautada na razão. A abordagem apriorística de dados e sua manipulação política evidenciam a instrumentalidade da razão e, assim, abre campo para as críticas que pretendemos formular.

Stephen Gould analisará as correntes antropológicas que estudaram o outro a partir de referenciais que são muito caros aos direitos humanos: o universalismo e

\footnotetext{
${ }^{60}$ GOULD, Stephen Jay. A falsa medida do homem. Trad. Valter Lellis Siqueira. Ed.2. São Paulo: Martins Fontes, 1999.

${ }^{61}$ Op. Cit.
} 
o relativismo. Ainda que Gould não faça um estudo jurídico ou filosófico dessas duas concepções, a análise desenvolvida no texto toca indiretamente essas concepções, interessando para nós a situação do relativismo antropológico em relação ao determinismo biológico, que será esboçada em comparação com o texto de Potz e Kuppe.

O determinismo biológico foi construído a partir de duas vertentes, sendo uma delas voltada para a ideia monogenista e outra para a ideia poligenista. O que essas duas vertentes têm em comum é a importância da determinação biológica, inexistindo qualquer referência à cultura. Gould explica que:

\begin{abstract}
As justificações pré-revolucionárias da hierarquia racial adotaram duas modalidades. $\mathrm{O}$ argumento "mais brando" - retomando definições impróprias de um ponto de vista moderno - sustentava a unidade de todos os povos através da criação única de Adão e Eva. Esta concepção foi denominada monogenismo, ou origem a partir de uma única fonte. As raças humanas são produtos da degeneração da perfeição do Paraíso. A degeneração atingiu diversos níveis, menor no caso dos brancos e maior no caso dos negros. O clima foi o fator invocado com mais freqüência como principal causa da distinção racial. Quanto à possibilidade de remediar os defeitos apresentados por certas raças modernas, as opiniões dos degeneracionistas estavam divididas. Alguns afirmavam que, embora gradualmente, geradas sob a influência do clima, as diferenças já estavam definidas e eram irreversíveis. Outros argumentavam que o fato de ter sido gradual esse desenvolvimento tornava possível a reversão em um meio ambiente adequado. (...) Mas outros degeneracionistas achavam que os resultados benéficos do clima não se manifestariam com rapidez suficiente para provocar algum tipo de repercussão na história humana. O argumento "duro" prescindiu da versão bíblica por considerá-la alegórica, e afirmou que as raças humanas eram espécies biológicas separadas e descendiam de mais de um Adão. Como os negros constituíam uma outra forma de vida, não participavam da "igualdade do homem". Os proponentes deste argumento foram chamados "poligenistas". ${ }^{62}$
\end{abstract}

Outra corrente passou a se preocupar com as diferenças, ou melhor, com a necessidade de se garantir direitos aos diferentes. Como analisa Gould, tendo como referência Thomas Jefferson e Charles Darwin, essa corrente defendia uma igualdade de direitos, em termos aristotélicos, ainda que diante de uma desigualdade racial, decorrendo daí os argumentos contra a escravidão, por exemplo. O ponto central dessa vertente residia no fato de haver aí uma pretensão de superação da diferença, por ser vista como vício.

Gould comenta que esse respeito à diversidade, apesar de ser bem intencionado, não compreendia de forma razoável o fato da diversidade, pois pretendia o assimilacionismo. A respeito Gould comenta:

\footnotetext{
${ }^{62}$ Op.Cit. P. 26.
} 
Entretanto, no conjunto da tradição igualitária do Iluminismo europeu e da Revolução Americana, não consigo discernir nenhuma posição popular comparável, ainda que remotamente, ao "relativismo cultural" que predomina (pelo menos da boca pra fora) nos círculos liberais de hoje. $\mathrm{O}$ argumento que mais se aproxima era a tese de que a inferioridade dos negros seria puramente cultural e que uma educação adequada poderia erradicá-la por completo, permitindo-lhes alcançar o nível do tipo caucasiano. ${ }^{63}$

Ana Lucia Pastore, comentando sobre o uso que foi pretendido pela elite intelectual brasileira do liberalismo, do darwinismo social e do evolucionismo, explica:

\begin{abstract}
Uma das principais ginásticas intelectuais desses políticos foi fazer com que o liberalismo e seus pressupostos da responsabilidade individual e do livre arbítrio, paradoxalmente dialogassem com o modelo darwinista social e com a teoria evolucionista, cujos pressupostos centrais eram os de que raças e sociedades evoluem de forma simples para complexas e, portanto, tendem a se aperfeiçoar continuamente, embora de acordo com critérios pré-estabelecidos pela "natureza" e, portanto, independentes das vontades dos sujeitos. O paradoxo residia, assim, no fato de o liberalismo colocar o indivíduo como senhor de suas ações e vontades enquanto o determinismo biológico e o evolucionismo apontavam limites "naturais" para o livre arbítrio. ${ }^{64}$
\end{abstract}

Neste ponto nos interessa especialmente a análise da legislação nacional, na medida em que podemos sentir a influência desses discursos no Direto brasileiro. O Estatuto do Índio, Lei 6001/73, diz em seu artigo $1^{\text {o: }}$ : Esta Lei regula a situação jurídica dos índios ou silvícolas e das comunidades indígenas, com o propósito de preservar a sua cultura e integrá-los, progressiva e harmoniosamente, à comunhão nacional. (grifamos e destacamos)

O fato é que é impossível integrar e preservar a cultura, no sentido proposto pela lei. O que é possível, como veremos mais à frente, é conviver e preservar cultura. O contrário é etnofagia, para nos valer de um termo de Héctor Díaz-Polanco. ${ }^{65}$

Como analisa Lilia Schwarcz ${ }^{66}$, a interferência das correntes antropológicas no Direito é de tal forma significativa que pode ser detectada não apenas nas leis vigentes, como se pode ver no Estatuto do Índio, mas também na literatura específica, por exemplo, as primeiras revistas das Faculdades de Direito de Recife e de São Paulo. Essa análise constitui o objeto da obra de Lilia Schwarcz por nós analisada.

\footnotetext{
${ }^{63}$ Op. Cit. P.20.

${ }^{64}$ Op. Cit.

${ }^{65}$ Cf. DIAZ-POLANCO, Héctor. Elogio de La Divesidad. Globalización, multiculturalismo e etnofagia. Editora Librisite.

${ }^{66}$ SCHWARKCZ, Lilia M. O Espetáculo das Raças. São Paulo: Companhia das Letras, 1993.
} 
A autora, tratando da influência das correntes analisadas acima no pensamento jurídico brasileiro, comenta:

A recepção dessas teorias científicas deterministas significava a entrada de um discurso secular e temporal que, no contexto brasileiro, transformava-se em instrumento de combate a uma série de instituições assentadas. No caso da faculdade de Recife, a introdução simultânea dos modelos evolucionistas e social-darwinistas resultou em uma tentativa bastante imediata de adaptar o direito a essas teorias, aplicando-as à realidade nacional. ${ }^{67}$

O que chama a atenção, ademais, não é apenas a interferência que essas correntes exercem no Direito oficial brasileiro somente. O próprio senso comum da cultura colonizadora mostra-se dominado pelas ideias deterministas, e exemplo dessa disseminação social do racismo pode ser encontrada nas obras da literatura nacional da época. Em O País do Carnaval, escrito por Jorge Amado em 1931, um dos personagens escreve o Poema da Mulata Desconhecida, reproduzido abaixo:

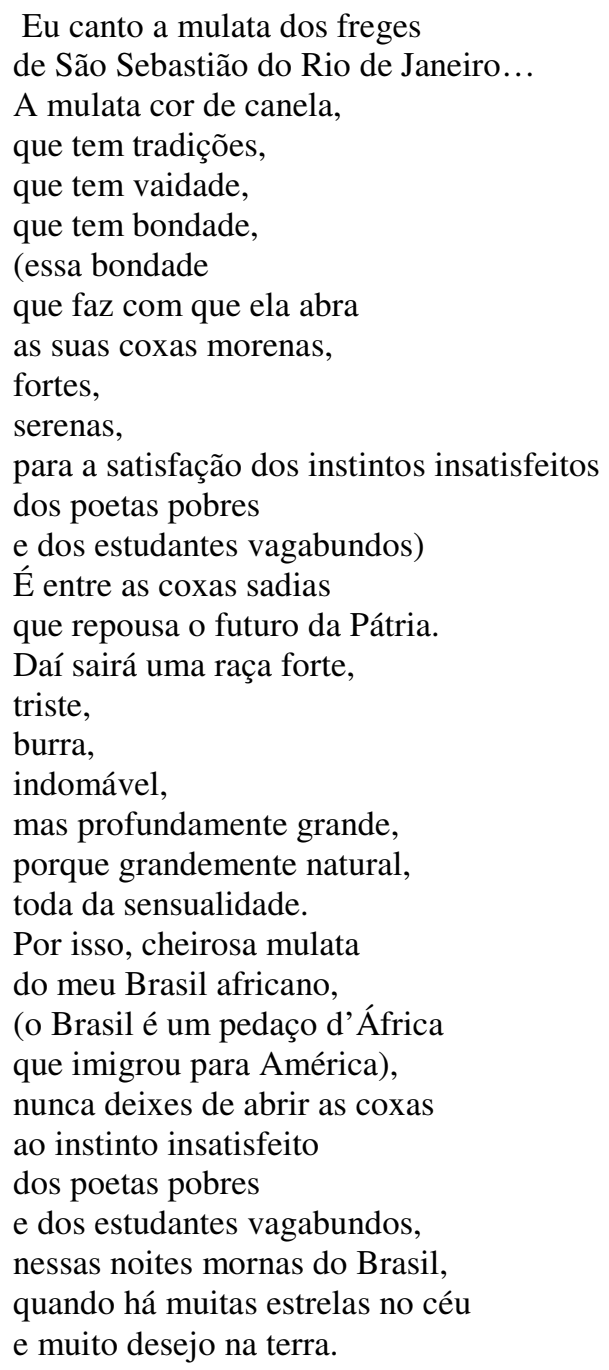

\footnotetext{
${ }^{67}$ Op. Cit. P.150.
} 
Esse senso comum da cultura dominante no Brasil teve também base na religiosidade cristã, assimilacionista e catequizadora por excelência, que durante muito tempo esteve ligada ao poder - encontrando ainda campo fértil para isso. A vinculação da consciência religiosa da cultura dominante ao poder além de ensejar um desrespeito a partir do Direito oficial enseja um desrespeito à diferença a partir da própria ideia de estima social, de acordo com Honneth. ${ }^{68} \mathrm{E}$ a esse respeito Eduardo Bittar, escrevendo sobre as religiões de matrizes africanas no Brasil, comenta:

\begin{abstract}
A importância do Estado Laico determina a qualidade da democracia. Por isso, onde há uma religião, oficial, e ela se confunde com o poder, ela se torna o símbolo da opressão unificadora, e, por isso, o avesso da salvaguarda democrática da diferença e do espaço de alteridades plurais. O êxtase místico e a sublimação do mundo da vida são práticas de cultura, expressões de religiosidade, cujo caráter multiforme não pode ser contido enquanto manifestação da liberdade. ${ }^{69}$
\end{abstract}

Voltando à análise acerca das teorias deterministas e assimilacionistas, parece interessante a análise central da obra de Gould a respeito dos estudos empíricos desenvolvidos por um dos principais poligenistas do século XIX, Samuel George Morton.

Vale fazer referência à reputação de Morton, de modo que nossas reflexões não fiquem, como todas as outras da mesma natureza, condenadas à força secundária que o Direito normalmente atribui às denominadas "ciências auxiliares". O jornal New York Tribune em 1851, quando do seu falecimento, publica: provavelmente, nenhum outro cientista americano gozou de maior reputação entre os estudiosos de todo o mundo que o Dr. Morton. ${ }^{70}$ Morton tinha a maior coleção de crânios do mundo e sua intenção foi demonstrar que uma hierarquia racial poderia ser determinada pelas características físicas do cérebro.

Morton desenvolveu um método que consistia em encher cavidades cranianas com sementes de mostarda peneirada e, após completar a cavidade, despejava as sementes em um cilindro graduado e obtinha o volume médio do cérebro em polegadas cúbicas. Gould estudou esse método e, analisando os crânios, verificou serias inconsistências metodológicas:

\footnotetext{
${ }^{68} \mathrm{Na}$ obra Luta por reconhecimento: a gramática moral dos conflitos sociais, Honneth aborda a questão do reconhecimento em três esferas, quais sejam, o amor, o direito e a solidariedade (a partir da noção de estima social). As implicações dessa concepção serão analisadas adiante.

${ }^{69}$ BITTAR, Eduardo C. B. O direito à tradição, as religiões de matrizes africanas e os direitos humanos. Seqüência, n. 61, p. 309-329, dez. 2010.

${ }^{70}$ OP. Cit. P.40.
} 
Durante o verão de 1977, passei várias semanas reavaliando os dados de Morton (Morton, que se declarava objetivista, publicou todos os seus dados brutos; portanto, podemos inferir com bastante segurança os passos que empreendeu para chegar aos resultados exibidos pelos quadros). Em poucas palavras, e para dizê-lo sem rodeios, os dados resumidos dos quadros formam uma colcha de retalhos de falsificações e acomodações evidentemente destinadas a verificar determinadas crenças a priori. $^{71}$

A respeito da medição dos crânios indígenas, Gould comenta:

Mas o valor "correto" de 80,2 é excessivamente baixo, pois resulta de um procedimento inadequado. Os 144 crânios de Morton pertencem a índios de muitos grupos diferentes, entre os quais existem diferenças significativas com relação à capacidade craniana. (...) A amostragem de Morton apresenta-se distorcida devido à presença majoritária de crânios pertencentes a um grupo extremo: o dos incas peruanos, cujo cérebro é pequeno (eles constituem $25 \%$ da amostragem e sua capacidade craniana média é de 74,36 polegadas cúbicas). Por outro lado, os iroqueses, cujo cérebro é grande, estão representados apenas por 3 crânios (ou seja, $2 \%$ da amostragem). ${ }^{72}$

Fica evidente, como propõe Gould, que a hierarquização foi uma opção a priori que acabou por determinar as questões "científicas". Se maiores ou menores os cérebros, essa questão não nos interessa essencialmente. O que chama a atenção é o fato da manipulação dos dados com o escopo de justificar um preconceito nada científico.

Em relação à teoria monogenista e às pretensões assimalacionistas do relativismo apontado por Gould, podemos estabelecer ainda uma relação com a corrente evolucionista tratada por Potz e Kuppe no texto supracitado. Partindo do foco da Antropologia do Direito, Kuppe e Potz analisam a forma pela qual eram estudados os sistemas jurídicos de povos (ditos) primitivos. Comentam que os estudiosos da época, eivados de pretensões a priori:

(...) trataram de incluir o material procedente de povos primitivos ou exóticos em uma ciência jurídica geral, e tudo isso durante uma época em que tais povos eram considerados como decadentes ou atrasados pelo resto das ciências européias. (...)

Não obstante, justamente foi esse estudo o propósito dos primeiros antropólogos jurídicos. Eles se dedicaram primeiramente à busca de escalas evolutivas na história do direito, para explicar as instituições jurídicas a partir de contextos socioculturais, e não a partir de consciências individuais. ${ }^{73}$

\footnotetext{
${ }^{71}$ Op. Cit. P. 48.

${ }^{72} \mathrm{Id}$. Ibd.

${ }^{73}$ Op. Cit. p.10. Tradução livre do original em espanhol: (...) trataron de incluir el material pocedente de pueblos primitivos o exóticos en una ciência jurídica general, y todo eso durante una época en la cual tales pueblos eran considerados como decadentes y obtusos por el resto de las ciencias europeas. (...)

Sin embargo, justamente fue ese estudio el propósito de los primeros antropólogos jurídicos. Ellos se dedicaron primeramente a la busqueda de escalas evolutivas en la historia del derecho, para explicar a las intituciones jurídicas a partir de contextos socioculturales, y no a partir de conciencias individuales.
} 
Comentam os autores, em nota, que apesar de ser muito conhecida na história da Antropologia a mudança paradigmática ocorrida em meados de 1900, substituindo o evolucionismo pelo relativismo, é bastante complicado fixar uma data precisa para essa transformação. Afirmam que: $\mathrm{Na}$ realidade, pode-se interpretar essa mudança como uma dinâmica entre as correntes que coexistiram paralelamente desde o início da disciplina. ${ }^{74} \mathrm{O}$ evolucionismo seria a expressão da pretensão de estudar comparativamente as instituições humanas; o relativismo seria a expressão da busca pelo conhecimento de outros seres humanos em contextos ditos exóticos.

\title{
O estudo do relativismo feito por Kuppe e Potz com um enfoque na
} Antropologia do Direito é particularmente interessante não só pelo fato de demonstrar como a Antropologia se prestou aos fins da dominação colonial, mas também por esclarecer de forma bastante didática o ponto nevrálgico do obstáculo relativista, qual seja, a tentativa de compreender a diferença a partir de paradigmas familiares do pesquisador.

\begin{abstract}
Assim, foram apresentadas cientificamente as instituições autóctones como se funcionassem da mesma maneira que a própria ordem jurídica (ocidental) dos pesquisadores. Se apresentavam como se se tratassem de normas jurídicas, de tribunais e instâncias impositoras do direito. Assim, a pesquisa antropológica chegou sempre ao seu resultado desejado; sobretudo, encontrou em cada sociedade o chefe, as estruturas de ordem, do mesmo modo que o mago sempre encontra o coelho branco em sua cartola. ${ }^{75}$
\end{abstract}

O interessante nessas constatações é o impacto que a politização etnocêntrica da ciência causa na história da humanidade. As teorias e o prestígio dos cientistas que manipularam pesquisas científicas justificaram fatos históricos como a escravidão, obtendo, inclusive, respaldo do Direito oficial no Estado colonizador. Do mesmo modo, a incapacidade de se desvencilhar das lentes culturais faz com que o pesquisador, no movimento de buscar no outro configurações semelhantes às suas próprias instituições (com singelas variações de forma), não consiga reconhecer a real diversidade

\footnotetext{
${ }^{74}$ Op. Cit. p.15. Tradução livre do original em espanhol: En realidad, se puede interpretar ese cambio como una dinámica entre las corrientes que coexistieron paralelamente desde el mismo inicio de la disciplina.

${ }^{75}$ Op. Cit. p.20. Tradução livre do original em espanhol: ¿Quién ejerció el poder en la África nativa?, ¿quién distribuyó la tierra ahí?, y ¿quién resolvió los conflictos? La disciplina antropológica se atribuyó la tarea de buscar las respuestas a éstas interrogantes; y, más aún, la de señalar que, detrás de las estructuras africana extrañas, funcionaba un cierto orden por descubrir. "!Encuentra al jefe!" (find the chief!) fue la fórmula imperante en varias obras monográficas de la antropología del derecho sobre África, a partir de los años treinta del siglo $X X$.

Así, fueron presentadas científicamente las instituciones autóctonas como si funcionaran de la misma manera que el propio orden jurídico (occidental) de los investigadores. Se presentaban como si se tratara de normas jurídicas, de tribunales e instancias impositoras del derecho. Así, la investigación antropológica llegó siempre a su resultado deseado; sobre todo, encontro em cada sociedad al jefe, a las estructuras del orden, al igual que el mago finalmente siempre encuentra al conejo banco em su sombrero mágico.
} 
e, com isso, obstaculiza qualquer forma de diálogo intercultural, já que em diálogos dessa natureza não pode permanecer subentendida a falsa sensação de que os interlocutores estão, sempre, falando sobre a mesma coisa. A esse respeito, Lévi-Strauss:

É preciso que saibam, ao contrário, que a humanidade é rica de possibilidades imprevistas, que, ao aparecerem, sempre deixarão os homens estupefatos; que o progresso não é feito à imagem confortável dessa similitude melhorada onde nós procuramos um esforço preguiçoso, mas que é repleto de aventuras, rupturas e escândalos. $^{76}$

Roy Wagner, em sua obra $A$ invenção da cultura, desenvolve um estudo acerca do método de pesquisa antropológico que, em maior ou menor grau, parecenos muito se assemelhar ao que defendemos com as propostas de diálogo intercultural. Roy Wagner defende a tese de que o ato de se estudar outras culturas buscando nelas encontrar instituições e configurações morais a partir das nossas próprias instituições e configurações, como se a questão fosse meramente de conteúdo. Ainda que existisse uma pretensão de respeito às diferenças, tem como resultado a invenção de uma nova cultura, não existente na realidade, mas apenas nas convicções do pesquisador.

O passo crucial - que é simultaneamente ético e teórico - consiste em permanecer fiel às implicações de nossa presunção da cultura. Se nossa cultura é criativa, então as "culturas" que estudamos, assim como outros casos desse fenômeno, também têm de sê-lo. Pois toda vez que fazemos com que outros se tornem parte de uma "realidade" que inventamos sozinhos, negando-lhes sua criatividade ao usurpar seu direito de criar, usamos essas pessoas e seu modo de vida e as tornamos subservientes a nós. E se criatividade e invenção emergem como as qualidades salientes da cultura, então é para elas que nosso foco deve voltar-se agora. ${ }^{77}$

Clifford Geertz, ao analisar o "saber local", também se manifesta nesse sentido, sugerindo:

Para minha mente limitada, o reconhecimento direto e franco dos limites - um dado observador, num certo momento e num dado lugar - é uma das coisas que mais recomenda todo esse estilo de realizar pesquisas. $\mathrm{O}$ reconhecimento do fato de que todos somos o que Renato Rosaldo chamou de "observadores posicionados (ou situados)" é uma de suas facetas mais atraentes e que mais conferem poder. A renúncia à autoridade proveniente das "visões que partem de lugar nenhum" ("Vi a realidade e ela é real") não constitui uma perda, mas um ganho; e não é um recuo, mas um avanço, a postura que diz: "Bem, eu, um norte-americano de classe média de meados do século XX, mais ou menos padrão, e do sexo masculino, fui a tal lugar, conversei com algumas pessoas que consegui induzir a falarem comigo, e acho que as coisas se passam com elas, por lá, mais ou menos de tal ou qual maneira." Talvez isso não seja excitante, mas tem uma certa franqueza (coisa escassa nas ciências humanas). As visões que partem de lugar nenhum podem ser imaginavelmente construídas, é claro. Quando bem feitas, podem ser e têm sido, nas

\footnotetext{
${ }^{76}$ LÉVI-STRAUSS, Claude. Antropologia Estrutural Dois. $4^{\circ}$ ed. Rio de Janeiro: Tempo Brasileiro, 1993. p. 366.

${ }^{77}$ WAGNER, Roy. A invenção da cultura. São Paulo: Cosac Naify, 2010. p.46.
} 
ciências naturais, de imensa utilidade. Mas, construídas desta maneira, são, na verdade, uma variedade particular das visões que partem de algum lugar - do estudo do filósofo, do computador do teórico. ${ }^{78}$

É possível notar, então, que o sistema de referência do ser humano é elemento determinante do processo cognitivo, logo, determinante de todas as obras humanas. Assim, duas questões se nos apresentam: (i) a politização etnocêntrica das teorias que influenciam o Direito oficial e (ii) a incapacidade do Direito oficial típico do Estadonação de, autonomamente, viabilizar uma politização saudável a partir de seu próprio sistema. Este, por sua vez, deveria se configurar como um sistema aberto e dinâmico e, com isso, conferir efetividade a uma proposta democrática de diálogo intercultural.

Para que essa abertura do Direito à dinâmica da humanidade seja possível, talvez seja necessário mesmo um salto paradigmático bastante sólido. A politização etnocêntrica é responsável pela retórica que analisamos neste tópico, enquanto a necessidade de flexibilidade do Direito oficial ocidental se justifica pelo fato de ser o Direito em si estudado e compreendido como uma ciência que transforma o que hoje é em dever ser - isso, aliás, é o que move a intenção de tornar um discurso jurídico “oficial”. Ou seja, o que hoje é entendido como algo bom deve permanecer como está e o que é entendido como algo mau deve ser controlado, reprimido. O Direito oficial do Estadonação colonizador não tem em si nenhum sonho, nenhum resquício de transformação, mas única e exclusivamente de dominação. O Direito oficial típico do Estado-nação não consegue se pôr socialmente como um dever ser com vistas ao que poderia ser melhor. Esse Direito observa causa e efeito, cartesianamente, como se a história fosse fruto simplesmente do balançar das árvores ou das tormentas marítimas.

O Direito típico do Estado-nação colonizador buscou na Antropologia premissas para serem transformadas em leis, mas não acompanhou a desconstrução que a própria Antropologia fez dessas premissas. É exatamente a partir dessas considerações/constatações, que a ideia de um universal abstrato acabou ruindo, exigindo, na sequência, novas formas de se pensar a convivência humana.

A interculturalidade, portanto, não pode pressupor um ambiente de lordes entupidos até o último fio de bigode de boa vontade. Nessa linha, a interculturalidade supera a ideia do universalismo abstrato, fundado nos imperativos categóricos kantianos, e também supera a ideia do multiculturalismo, baseado na formulação de políticas públicas altruístas. Ainda que exista uma confusão semântica entre

\footnotetext{
${ }^{78}$ GEERTZ, Clifford. Nova luz sobre a Antropologia. Trad. Vera Ribeiro. Rio de Janeiro: Jorge Zahar Ed., 2001. p. 126.
} 
muticulturalismo e interculturalidade, ${ }^{79}$ as reflexões que têm sido feitas a partir da noção de multiculturalismo têm partido de uma ideia, sim, de respeito à diferença, mas de uma diferença controlada, administrada por uma cultura hegemônica que justifica a noção de tolerância.

A interculturalidade, como a entendemos para os fins deste trabalho, parte da ideia de que esse universal é um ponto de chegada apesar de não desconsiderar a ideia de uma construção de referenciais universais, e a esse respeito retomamos a citação de Joaquim Herrera Flores no sentido de que: $O$ que negamos é considerar o universal como um ponto de partida ou um campo de desencontros. Ao universal há que se chegaruniversalismo de chegada ou de confluência - depois (não antes) de um processo conflitivo, discursivo de diálogo (...). ${ }^{80}$

As diferenças entre multiculturalismo e interculturalidade serão melhor desenvolvidas no próximo tópico, sendo interessante por ora compreender o outro como o "não eu" e, ao mesmo tempo, como uma "possibilidade que existe em mim", como alguém com quem preciso conviver e, para tanto, conhecer para me expandir. Essa questão será objeto de análise no próximo tópico. A interculturalidade deve pressupor os cuidados que o próprio método de pesquisa antropológica evidenciou como pré-requisito para que realmente se conheça o outro, ao invés de, nos valendo da ideia de Roy Wagner, criar o outro, atribuindo a ele, esquizofrenicamente, características que são minhas.

Neste ponto, contudo, cabe propor linhas de reflexão acerca da interculturalidade como um processo que, como destino, tem a construção de um ambiente de convivência e não meramente de tolerância. Como pensar esse processo e como garantir a proteção da dignidade humana nesse processo é uma questão para o Direito (agora sim abstratamente considerado, enquanto sistema de normas garantidoras de direitos) o que, talvez, apenas possa ser feito a partir da semântica dos Direitos Humanos, como analisaremos no último capítulo deste trabalho. Podemos afirmar que tolerância é pouco, pois, como dito, não contribui para o conhecimento do outro, mas apenas o detecta como um ser vivo, e a interculturalidade pressupõe a consideração sensível do outro de forma completa, enquanto ser humano.

\footnotetext{
${ }^{79}$ Juntamente com a pesquisadora Vanessa C. Teixeira estamos desenvolvendo uma análise teórica das discussões que envolvem multiculturalismo e interculturalidade. A proposta é realizar um levantamento sistemático da bibliografia que tem abordado temas relacionados a esses conceitos e traçar um esquema dos usos que diversos pensadores fazem dessas categorias.

80 FLORES, Joaquin Herrera. Direitos Humanos, Interculturalidade e Racionalidade de Resistência. Sequência (UFSC), vol. 23, n. 44. 2002. ISSNe 2177-7055. p. 09 a 29.
} 
A respeito desse contato enquanto convivência sensível trabalharemos no tópico 2.3. No tópico seguinte fixaremos a linha divisória que entendemos existir entre multiculturalismo e interculturalidade.

\section{2- INTERCULTURALIDADE E MULTICULTURALISMO: ONDE ACABA O COLONIALISMO?}

O tópico anterior teve por objetivo esclarecer o que entendemos existir na questão da diversidade cultural para pensar a interculturalidade. Parece existir uma correlação bastante sólida entre os paradigmas iluministas que orientaram as primeiras construções antropológicas sobre o "outro" não-ocidental e a perpetuação da situação colonial dos povos indígenas, especificamente na América Latina. Além dessa correlação, também vislumbramos um reflexo dessas "certezas científicas" no discurso jurídico até hoje, e é neste ponto que nos concentramos neste apartado.

A análise de como as teorias antropológicas dos séculos XVIII e XIX justificaram a situação colonial dos povos tradicionais e, do mesmo modo, como justificaram discursos jurídicos que legitimaram o uso da força para a sua submissão (especialmente o assimilacionismo catequizante), é facilmente verificada no estudo que fizemos no tópico anterior. No entanto, também deixamos claro que a própria Antropologia quebrou esses paradigmas na virada do século XIX para o XX e caminhou rumo a outras construções que, se consideradas de fato, deslegitimariam qualquer discurso colonizador, jurídico ou político. Isso porque o que passou a ser objeto de busca de legitimidade não mais era o atraso ou avanço de uma cultura (ou raça) em relação a outras, mas na tomada de consciência da inviabilidade de comparação nesses termos. Clifor Geertz, escrevendo sobre a influência do "saber local" na pesquisa antropológica, comenta: Se você quiser uma boa generalização prática de antropologia, sugiro a seguinte: qualquer frase que comece por “Todas as sociedades têm..." é infundada ou banal. ${ }^{81}$

O problema das generalizações e comparações com a finalidade de fixar classificações hierárquicas entre culturas foi superado, como analisamos no tópico anterior, na virada do século XIX para o século XX. No entanto, o que nos interessa para o presente trabalho é que nem na realidade política, nem no Direito, essa mudança paradigmática teve eco suficientemente forte para podermos falar em interculturalidade.

\footnotetext{
${ }^{81}$ Op. Cit. p. 126.
} 
O primeiro passo metodológico necessário para pensarmos interculturalidade da maneira como a trabalhamos aqui exige uma análise do que tem sido pensado em termos de "colonialismo", especificamente na América Latina. Essa análise não é importante somente por trazer para a pesquisa um diálogo entre os teóricos críticos da Escola de Frankfurt (que orientam nossas reflexões) e os teóricos latinoamericanos, mas principalmente por situar as nossas reflexões onde as relações de opressão assumem não apenas uma feição de classes (capital/burguesia - versus trabalho/proletariado), mas onde assumem também um matiz essencialmente étnico.

A análise do colonialismo persistente na América Latina a partir da própria realidade pluricultural latinoamericana traz para a nossa mesa questões centrais para o debate em tela. Ademais, na linha do que dissemos a respeito da teoria crítica, a situação dos problemas no mundo da vida é o que orienta o pensador crítico. Ao considerar, ao mesmo tempo, a pobreza dos povos indígenas e a falta de reconhecimento de suas diferenças culturais, bem como a hegemonia no Estado nacional pela cultura colonizadora, o estudo das características do colonialismo na América Latina esclarece que a análise crítica do que tem sido feito em termos de políticas públicas e organização de movimentos sociais nesta região pluricultural não pode se restringir à análise apenas da questão capital $x$ trabalho enquanto acesso aos meios de produção, pois o próprio modelo de produção e a lógica do seu tempo estão em debate.

Uma situação histórica e política interessante desse problema e que nos parece fazer sentido nesta parte do trabalho pode ser encontrada nas reflexões de Enrique Dussel sobre a busca de uma identidade filosófica na América Latina sobre uma nova forma de compreensão das relações de opressão, que passaram a se dar em termos de "centro" e "periferia", e não mais "colônia" e "metrópole".

Desde o final da década de 60, e como fruto do surgimento das ciências sociais críticas latinoamericanas (em especial a Teoria da Dependência), pela leitura de Totalidade e Infinito de Emmanuel Levinas, e principalmente pelos movimentos populares e estudantis de 1968 (no mundo, mas fundamentalmente Argentina e América Latina), se produziu no campo da filosofia, e por isso na filosofia da cultura, uma ruptura histórica. O que havia sido o mundo metropolitano e o mundo colonial agora (a partir da terminologia desenvolvimentista de Raúl Presbich na CEPAL) se categoriza como "centro" e "periferia". A isso se terá que agregar todo um horizonte categorial que procede da economia crítica que exige a incorporação das classes sociais como atores intersubjetivos a serem integrados em uma definição de cultura. ${ }^{82}$

\footnotetext{
${ }^{82}$ DUSSEL, Enrique. Op. Cit. Tradução livre do original: Desde los finales de la década del 60, y como fruto del surgimiento de las ciencias sociales críticas latinoamericanas (en especial la "Teoría de La dependencia”), y por la lectura de Totalidad e infinito de Emmanuel Levinas, y quizá inicial y
} 
Esse deslocamento proposto por Dussel foi muito bem apropriado por

Pablo Gonzales Casanova no seu estudo sobre a noção de "colonialismo interno":

\begin{abstract}
A definição do colonialismo interno está originalmente ligada a fenômenos de conquista, em que as populações de nativos não são exterminadas e formam parte, primeiro do Estado colonizador e depois do Estado que adquire uma independência formal, ou que inicia um processo de libertação, de transição para o socialismo, ou de recolonização e regresso ao capitalismo neoliberal. Os povos, minorias ou nações colonizadas pelo Estado-nação sofrem condições semelhantes às que os caracterizam no colonialismo e no neocolonialismo em nível internacional: 1) habitam em um território sem governo próprio; 2) encontram-se em situação de desigualdade frente às elites das etnias dominantes e das classes que as integram; 3) sua administração e responsabilidade jurídico-política concernem às etnias dominantes, às burguesias e oligarquias do governo central ou aos aliados e subordinados do mesmo; 4) seus habitantes não participam dos mais altos cargos políticos e militares do governo central, salvo em condição de "assimilados"; 5) os direitos de seus habitantes, sua situação econômica, política social e cultural são regulados e impostos pelo governo central; 6) em geral os colonizados no interior de um Estado-nação pertencem a uma "raça" distinta da que domina o governo nacional e que é considerada "inferior", ou ao cabo convertida em um símbolo "libertador" que forma parte da demagogia estatal; 7) a maioria dos colonizados pertence a uma cultura distinta e não fala a língua "nacional". Se como afirmara Marx "um país se enriquece às custas de outro país" igual a "uma classe se enriquece às custas de outra classe", em muitos Estadosnação que provêm da conquista de territórios, chame-se Impérios ou Repúblicas, a essas duas formas de enriquecimento juntam-se as do colonialismo interno (Marx, 1963: 155 , Tomo I). ${ }^{83}$
\end{abstract}

Pensamos ser fundamental considerar a ideia de que o colonialismo não ocorre apenas no âmbito internacional, mas também dentro de um Estado-nação e se perpetua até os dias de hoje na América Latina. Afinal, as principais pautas de luta dos povos indígenas têm no Estado enquanto entidade monocultural e colonizadora o seu foco principal de luta. ${ }^{84} \mathrm{~A}$ esse respeito, também consideramos fundamental a noção de capital cultural proposta por Álvaro Garcia Linera, que, em íntima ligação com a ideia de colonialismo, explica esse conceito da seguinte maneira:

Da mesma forma, nos termos das práticas culturais, está claro que terão maiores probabilidades de acumulação de outros tipos de capital cultural aqueles que, como

principalmente por los movimientos populares y estudiantiles del 1968 (en el mundo pero fundamentalmente en Argentina y América Latina), se produjo en el campo de la filosofía y por ello en la filosofía de la cultura, una ruptura histórica. Lo que había sido el mundo metropolitano y el mundo colonial, ahora (desde la terminología todavía desarrollista de Raúl Presbisch en la CEPAL) se categorizar como "centro" y "periferia". A esto habrá que agregar todo un horizonte categorial que procede de la economía crítica que exigía la incorporación de las clases sociales como actores intersubjetivos a integrarse en una definición de cultura.

${ }^{83}$ GONZÁLEZ CASANOVA, Pablo. Colonialismo interno (uma redefinição). In: "A teoria marxista hoje. Problemas e perspectivas". Boron, Atilio A.; Amadeo, Javier; Gonzalez, Sabrina. 2007 ISBN 9789871183678.

${ }^{84}$ A esse respeito, vide o documento anexo I, elaborado pela Articulação dos Povos Indígenas do Brasil (APIB), por ocasião do VIII Acampamento Terra Livre. 
os mestiços urbanos, desde o Estado têm definido seus conhecimentos e habilidades particulares como práticas culturais legítimas, socialmente valorizadas; enquanto os indígenas, possuidores de outros hábitos e costumes, terão menos opções de ascensão e acumulação cultural, pois não tiveram acesso a produção dessas habilidades como parte de seu entorno imediato, e, para conhecê-las, têm que realizar um esforço maior para entendê-las, assimilá-las e utilizá-las de maneira eficiente. $^{85}$

É bastante evidente que uma das preocupações centrais dos que analisam a situação dos povos indígenas na América Latina reside no etnocentrismo estatal que, por conseqüência, reflete no Direito através do discurso colonizador da cultura que ocupa o Estado.

Ainda em relação à contextualização crítica da interculturalidade na América Latina, consideramos bastante importante um diálogo - ainda que breve - com o pensamento do peruano José Carlos Mariátegui, por abordar uma questão importantíssima para o presente trabalho na medida em que traça de forma bastante clara uma linha distintiva entre o que tomamos como objeto de reflexão e o que apenas consideraremos no curso da nossa pesquisa.

A obra de Mariátegui caminha no sentido da proposta de construção de um socialismo latino-americano. No presente trabalho, ainda que nos pareça uma empreitada relevante para a luta dos povos tradicionais, não pretendemos analisar a proposta de um socialismo como via emancipatória para os povos indígenas (e nem teríamos condições de fazê-lo aqui), mas a análise das ideias de Mariátegui nos parece importante por dois motivos.

O primeiro motivo é exatamente a proposta de situar o debate que pretendemos desenvolver acerca da interculturalidade na realidade dos povos indígenas latino-americanos, ou seja, de situar nossas reflexões no espaço onde ocorreram as principais experiências de lutas indígenas contra o Estado. ${ }^{86} \mathrm{O}$ segundo ponto é a consideração da relevância que Mariátegui atribuiu ao fator econômico: Todas as teses

\footnotetext{
${ }^{85}$ Op. Cit. Tradução livre do original em espanhol: De la misma forma, en términos de las prácticas culturales, está claro que tendrán mayores probabilidades de acumulación de otros tipos de capital cultural aquellos que, como los mestizo-urbanos, desde el Estado han definido sus conocimientos y habilidades particulares como prácticas culturales legítimas, socialmente valoradas; en tanto que los indígenas, poseedores de otros hábitos y costumbres, tendrán menos posiciones de ascenso y acumulación cultural, porque no han accedido a la producción de esas habilidades como parte de su entorno inmediato, y, para conocerlas, tienen que realizar un esfuerzo mayor para entenderlas, asimilarlas y utilizarlas de manera eficiente.

${ }^{86}$ Sobre a questão vide URQUIDI. V. TEIXEIRA, V. e LANA, E. Questão Indígena na América Latina: Direito Internacional, Novo Constitucionalismo e Organização dos Movimentos Indígenas, in Cadernos Prolam-USP, ano VII, Vol. I, 2008. p. 199-222.
} 
sobre o problema do índio que ignoram seus aspectos econômico-social são exercício teóricos estéreis. ${ }^{87}$

O que Mariátegui sugere, dentro de sua proposta política, é que, para a solução dos problemas do índio (considerando o foco dado por ele na realidade peruana), o acesso aos meios necessários para a sobrevivência e reprodução socioeconômica do índio seria imprescindível. No entanto, o que nos toca nessa construção teórica é exatamente aquilo que Casanova chamou de "indigenização da luta de classes", ${ }^{88}$ dando um passo a frente para a consideração das peculiaridades étnicas da América Latina.

Essa construção de Mariátegui, que une a questão de classe à questão do índio e, nessa união, deixa claro que se trata de questões distintas, contribuiu de forma relevante para o debate acerca do colonialismo. Mariátegui trabalha com uma categoria que, na linha das nossas reflexões, esclarece o peso do colonialismo interno na luta dos povos indígenas. Essa categoria é o gamonalismo.

"Gamón” é uma planta daninha, parasita, que mata outras plantas que com ela dividem um mesmo ambiente. A explicação do próprio Mariátegui para aquilo que pretende chamar de gamonalismo é a seguinte:

O termo gamonalismo não designa apenas uma categoria social e econômica: a dos
latifundiários ou grandes proprietários agrícolas. Designa todo um fenômeno. O
gamonalismo não está representado somente pelos gamonais propriamente ditos.
Compreende uma grande hierarquia de funcionários, intermediários, agentes,
parasitas etc. O índio alfabetizado se transforma em um explorador de sua própria
raça porque se põe a serviço do gamonalismo. A definição de gamonalismo nos parece relevante não apenas por esclarecer pontos relevantes da preocupação de Mariátegui e que dialogam com a noção de colonialismo interno (latifúndio, Estado nacional, etnocentrismo, capital cultural), mas principalmente por se referir ao fenômeno do índio que, uma vez alfabetizado, passa a explorar os outros índios. Essa constatação parece ser uma abertura reflexiva importante

\footnotetext{
${ }^{87}$ MARIÁTEGUI, José Carlos. 7 Ensayos de interpretació de La realidad peruana. 3.ed. Caracas: Fundação Biblioteca Ayacucho, 2007. P.26.

${ }^{88}$ Op. Cit. Mariátegui indigenizou a luta de classes; indigenizou a luta anti-imperialista e colocou a necessidade de fazer outro tanto em qualquer país ou região onde houvesse populações colonizadas, etnias, povos oprimidos, minorias ou nacionalidades em condições dessa exploração, discriminação e dominação que distingue os trabalhadores das etnias dominantes, ou “assimilados”, frente aos trabalhadores das etnias dominadas, discriminadas, excluídas.

${ }^{89}$ Op. Cit. P.28. Tradução livre do original: El término 'gamonalismo' no designa sólo una categoría social y económica: la de los latifundistas o grandes propietarios agrarios. Designa todo un fenómeno. El gamonalismo no está representado sólo por los gamonales propiamente dichos. Comprende una larga jerarquía de funcionarios, intermediarios, agentes, parásitos, etc. El indio alfabeto se transforma en un explotador de su propia raza porque se pone al servicio del gamonalismo.
} 
para que o nosso trabalho dialogue com algumas ideias da obra de Mariátegui. Nos parece que essa questão colocada por Mariátegui justifica, sim, o foco na questão da terra (na questão econômica), mas do mesmo modo permite o desenvolvimento de temas relacionados com isso que vamos chamar aqui de "encanto pelo ocidentalismo".

A questão, então, que tiramos das reflexões de Mariátegui é: Por que, ao adquirir meios materiais de subsistência e conhecimento do funcionamento do Estado e da cultura colonizadora, alguns índios começam a explorar outros índios? A constatação de que o acesso ao "conforto/encanto" do capitalismo enseja a exploração do índio pelo próprio índio já justifica a preocupação com temas como indústria cultural e reconhecimento, que não se vinculam em todos os termos de forma direta com o tema da luta de classes. Assim, temos que considerar que existem dois momentos: 1- o acesso aos bens materiais para instrumentalizar a descolonização e a luta por reconhecimento das diferenças culturais; 2- o acesso a esses bens e o encantamento com o conforto do capitalismo, que gera desejos distantes da luta pelo reconhecimento das diferenças.

A constatação de que após o acesso aos bens materiais que permitiriam certa autonomia aos povos indígenas outras questões de ordem psicológica e cultural deverão ser enfrentadas nos leva à seguinte conclusão: tanto no momento de luta pelo acesso a esses bens como na luta pela autonomia de ter condições de permanecer na cultura de origem estaremos diante de questões políticas, de diálogo, de crises e de consensos. Esse segundo momento é que nos provoca neste trabalho, pois consideramos que é a emancipação completa dos povos indígenas que fará a diferença e evitará o conforto na indústria cultural que, como comentou Mariátegui, acaba representando apenas a reprodução da opressão.

Essa noção de colonialismo é essencial para que possamos definir e distinguir multiculturalismo e interculturalidade, pois o "multiculturalismo" é apenas um avanço de tolerância das diferenças dentro de um esquema ainda colonial. Para iniciarmos essa análise, tomaremos como base reflexiva o que Dussel chamou de "multiculturalismo altruísta”.

A essas culturas que não são nem "metropolitanas" nem "primitivas", as vão
destruindo por meio da propaganda, da venda de mercadorias, produtos materiais
que são sempre culturais (como bebidas, comidas, vestidos, veículos etc.), ainda que
por outro lado se pretenda salvar essas culturas valorizando isoladamente elementos
folclóricos ou momentos culturais secundários. Uma transnacional da alimentação
pode inserir nos seus menus um prato próprio de uma cultura culinária (como o
"Taco Bell"). Isso passa por "respeito" às outras culturas.
Esse tipo de multiculturalismo altruísta se mostra claramente formulado no
"overlapping consensus" de John Rawls, que exige a aceitação de certos princípios 
procedimentais (que são inadvertidamente profundamente culturais, ocidentais) que devem ser aceitos por todos os membros de uma comunidade política e permitindo, ao mesmo tempo, a diversidade valorativa cultural (ou religiosa). Politicamente isso significaria aos que estabelecem o diálogo aceitar um Estado liberal multicultural, não advertindo que a estrutura mesma desse Estado multicultural, tal como se institucionaliza no presente, é a expressão da cultura ocidental e restringe a possibilidade de sobrevivência de todas as demais culturas. Sub-repticiamente temse imposto uma estrutura cultural em nome de elementos puramente formais da convivência que tem sido expressão de desenvolvimento de uma cultura determinada. Ademais, não se tem clara consciência que a estrutura econômica de fundo é o capitalismo transnacional, que funda esse tipo de Estado liberal e que tem anulado nas culturas "incorporadas", graças ao indicado "overlapping consensus" (ação de esvaziamento prévio dos elementos críticos anticapitalistas dessas culturas), diferenças antiocidentais inaceitáveis. ${ }^{90}$

Dessa análise de Dussel destacamos alguns pontos: 1- a aceitação da cultura menos expressiva apenas como consumidora; 2- a valorização isolada de elementos culturais secundários; 3- a aceitação/imposição de princípios procedimentais dialógicos ocidentais (etnocêntricos); 4- a estrutura do Estado multicultural como expressão da cultura ocidental; 5- a noção de incorporação da cultura menos expressiva. Caminhemos um pouco mais na análise de outros autores na busca de semelhanças com a definição de "multiculturalismo altruísta" de Dussel.

Zygmund Bauman, em sua obra Em busca da política, retoma uma distinção proposta por Alain Touraine entre "sociedade multicultural" e "sociedade multicomunitária" e sugere que, enquanto o multiculturalismo partiria da ideia da tolerância das diferenças culturais aceitáveis e da admissão do livre trânsito entre as opções culturais, o multicomunitarismo, ainda que reconheça a existência de diferenças, não admitiria a possibilidade de intercâmbio cultural.

\footnotetext{
${ }^{90}$ Op. Cit. Tradução livre do espanhol: A esas culturas que no son ni metropolitanas" ni "primitivas”, se las va destruyendo por medio de la propaganda, de la venta de mercancías, productos materiales que son siempre culturales (como bebidas, comidas, vestidos, vehículos, etc.), aunque por otro lado se pretende salvar dichas culturas valorando aisladamente elementos folklóricos o momentos culturales secundarios. Una trasnacional de loa alimentación puede subsumir entre sus menús un plato propio de una cultura culinaria (como el "Taco Bell”). Esto pasa por "respeto" a las otras culturas.

Este tipo de multiculturalismo altruista queda claramente formulado en el "overlapping consensus" de un John Rawls, que exige la aceptación de ciertos principios procedimentales (que son inadvertidamente profundamente culturales, occidentales) que deben ser aceptados por todos los miembros de una comunidad política, y permitiendo al mismo tiempo la diversidad valorativa cultural (o religiosa). Políticamente esto supondría en los que establecen el diálogo aceptar un Estado liberal multicultural, no advirtiendo que la estructura misma de ese Estado multicultural tal como se institucionaliza en el presente es la expresión de la cultura occidental y restringe la posibilidad de sobrevivencia de todas las demás culturas. Subrepticiamente se ha impuesto una estructura cultural en nombre de elementos puramente formales de la convivencia (que han sido expresión del desarrollo de una cultura determinada). Además, no se tiene clara conciencia que la estructura económica de fondo es el capitalismo trasnacional, que funda ese tipo de Estado liberal, y que ha limado en las culturas "incorporadas", gracias al indicado "overlapping consensus" (acción de vaciamiento previo de los elementos críticos anticapitalistas de esas culturas) diferencias anti-occidentales inaceptables.
} 
A primeira (visão - comentário nosso) refere-se a uma sociedade tolerante com as diferenças culturais, com o livre fluxo de propostas culturais e a liberdade de opções culturais; uma sociedade preparada para negociar continuamente a fronteira móvel entre diferenças aceitáveis de estilos de vida e crimes puníveis. (...) Em outras palavras, o multiculturalismo é consciente na sua fidelidade à liberdade como valor supremo: para ser autêntica, a liberdade de opção cultural deve incluir o direito de optar por sair de "uma cultura", tanto quanto implica o direito de optar pelo regresso (demanda contra a qual o "multicomunitarismo" se levanta em armas).

A segunda visão/programa proclama a preservação das diferenças culturais do grupo existentes como sendo um valor em si mesmo. (...) $)^{91}$

Como estamos falando de interculturalidade e diálogo intercultural, o que nos interessa nessa classificação de Bauman é a atenção para o ponto referente à tolerância de diferenças “aceitáveis”. Essa concepção é problemática, pois a cultura não é um objeto compartimentado, plenamente dimensionado, que colocamos em nossas mochilas ao sair de casa. Não há como tolerar apenas metade de uma cultura (essa prática e aquela outra), pois cada prática cultural tem uma referência tópica, reflexiva, que vai do inconsciente coletivo ao consciente individual e vice-versa.

Ainda que Bauman não conduza a discussão no sentido de análise crítica desse ponto e na definição de tópicos claros para o desenvolvimento de algo além do multiculturalismo, ele sugere um tópico de discussão que parece relevante para nossas reflexões: a necessidade de se compreender que não existe mais a possibilidade de pensarmos, hoje, em culturas homogêneas, como fatos emoldurados ou involucrados pela ideia de pureza.

Por fim, "multiculturalismo" implica tacitamente estar encerrado numa totalidade saudável de ser-no-mundo, enquanto todas as demais situações - ser "transcultural", nutrir-se simultaneamente de "culturas diversas" ou simplesmente não se preocupar com a "ambiguidade cultural" de sua posição - são situações anormais, "híbridas" e potencialmente monstruosas, mórbidas e impróprias para viver. Todas essas entidades e o que sugerem e implicam são produto de uma moldura ou estrutura cognitiva - e esta moldura, legado do "pensamento sistêmico" outrora dominante no pensamento sociológico, é singularmente inadequada para apreender a experiência especificamente pós-moderna, fossem quais fossem os seus méritos no passado.

(...)

Há uma intenção ideológica por trás de cada visão de "cultura homogênea", e a ideia de heterogeneidade cultural paga tributo evidente a essa ideologia. Tal ideologia raramente foi ressaltada, quanto mais questionada em condições radicalmente diversas das nossas - quando refletia a prática moderna da homogeneização patrocinada pelo poder. Essa ideologia estava á vontade no mundo da construção nacional, das cruzadas culturais, da implantação de padrões uniformes sobre a variedade de estilos de vida, de assimilação forçada e de busca de harmonia cultural. Desde então, porém, o mundo mudou o suficiente para despojar essa ideologia de

\footnotetext{
${ }^{91}$ BAUMAN - Em busca da política. Trad. Marcos Penchel. Rio de Janeiro: Jorge Zahar Ed., 2000. p. 200.
} 
sua influência na prática política e assim solapar sua reivindicação sobre a realidade. $^{92}$

Essa compreensão exige a apreensão da dimensão dinâmica das culturas e do inevitável contato entre culturas. Não existe mais espaço para polarizações, pois as polarizações demandam tolerância, e tolerar nos parece pouco. A convivência, a troca complexa e dialógica de experiências e compreensões de mundo não pode mais permanecer maculada como alternativa de se viver em um mundo inconstante, complexo, dinâmico e, em muitos aspectos, parafraseando Bauman, líquido. Pressupostos que abordam a cultura como realidade estática estão fora do nosso tempo, situados em qualquer lugar, menos no mundo da vida.

Nesse sentido, a ideia de multiculturalismo que Bauman se utilizou para trabalhar a possibilidade de "convivência num mundo das diferenças" apresenta características semelhantes à definição de "muticulturalismo altruísta" de Dussel. Enquanto Dussel fala da aceitação da outra cultura como consumidora e da valorização de elementos culturais secundários, Bauman fala de um contato (coexistência tolerante) mediado pelas diferenças aceitáveis. Essas características dizem muito sobre a concepção de tolerância, que carrega consigo não uma relação simétrica de respeito (típica da convivência), mas uma relação de respeito sínico imposta pela fatalidade da coexistência.

A cultura hegemônica colonizadora apenas tolera a cultura menos expressiva politicamente, quando o faz, e desde que esta cultura consuma o seu excedente e mantenha as suas práticas estranhas no âmbito privado de seus redutos concedidos (e não conquistados). Em troca, ou melhor, como manifestação sínica de respeito, a cultura dominante permite que se fale da cultura minoritária nas escolas e, nos restaurantes inacessíveis à cultura minoritária, a cultura dominante também admite que sejam servidos pratos "típicos" do "outro exótico".

É interessante analisar como o termo "multiculturalismo" ainda oscila nos textos daqueles que pretendem pensar sobre o tema. Roberto Cardoso de Oliveira cita uma experiência de diálogo interétnico que, dentro de nossa proposta, seria ainda multiculturalismo, ou seja, imposição discursiva. Comentando acerca da habilidade de indígenas Tukuna (lideranças ou não) com o discurso político nacional, mencionando também outro exemplo, o da chefia de postos da FUNAI por indígenas da reserva dos Uaça, Cardoso de Oliveira conclui:

\footnotetext{
${ }^{92}$ Idem. p. 202.
} 
Portanto, o que se vê atualmente é que em diferentes partes do nosso hemisfério começam a surgir líderes indígenas bastante competentes no uso da linguagem do polo dominante, fato reconhecido em nível do hemisfério pelo Instituto Indigenista Interamericano; i.é, muito mais do que conhecedores do idioma português, inglês, francês ou espanhol, essas lideranças são capazes de se movimentar no interior das normas do discurso hegemônico, o que lhes permite conduzir uma argumentação audível e inteligível no interior do campo indigenista, sem serem obrigados a institucionalizar uma nova normatividade sustentadora do diálogo interétnico - algo bem mais difícil de se alcançar. Mas se isso não é tudo (pois infelizmente fica sempre marginalizada desse diálogo a grande maioria da população indígena), também isso não é pouco, se considerarmos que é um fato que deve mostrar um rumo para uma política indigenista voltada para preparar o índio a se tornar um competente interlocutor e não um mero cliente de eventuais benesses do Estado ou mesmo de segmentos da sociedade civil. ${ }^{93}$

Não se discute a importância desse acesso dos indígenas à cultura do colonizador, e também Roberto Cardoso de Oliveira afirma que "isso não é tudo". E isso não é tudo pelo fato de que ocupar cargos no governo e falar a língua do colonizador não é mais do que exemplo de mera tolerância, de dominação simbólica que, como chamou a atenção Mariátegui, pode ensejar a dominação do índio pelo próprio índio. Ainda a respeito do domínio da língua, vale citar uma passagem de Carlos Frederico Marés, que retomaremos novamente mais adiante, que diz: Não raras vezes o multiculturalismo aplicado se traduz em conteúdo universal expresso em línguas diferentes, o que é também uma imposição ou colonialismo cultural, mais eficiente talvez. ${ }^{94}$

O multiculturalismo (altruísta, tolerante) pode até ser um primeiro passo, mas não é suficiente. Essa descrição de Roberto Cardoso de Oliveira sem dúvida alguma aponta para um cenário dialógico importante, pois sabemos que os indígenas têm dificuldade de exercer cidadania por não conhecerem a burocracia estatal e a cultura que o define. No entanto, permanecem nessa descrição de Cardoso de Oliveira outras três características do multicultiralismo que extraímos da abordagem de Dussel, quais sejam: 1a estrutura do Estado multicultural como expressão da cultura ocidental; 2- a aceitação/imposição de princípios procedimentais dialógicos ocidentais (etnocêntricos); 3a incorporação da cultura menos expressiva à hegemônica.

A respeito dessas três características Habermas (ainda que trabalhando com o termo multiculturalismo) propõe uma compreensão bastante clara de como essa relação entre culturas deveria ocorrer. O próprio título do capítulo do livro A inclusão do

93 CARDOSO DE OLIVEIRA, Roberto. Ação indigenista, eticidade e o diálogo interétnico. Estudos Avançados, volume 14, n. 40. Setembro/Dezembro 2000. p. 213-230

${ }^{94}$ MARÉS, Carlos Frederico. As novas questões jurídicas nas relações dos Estados nacionais com os índios. In. "Além da tutela: bases para uma nova política indigenista III." Org. LIMA, Antonio Carlos de Sousa. HOFFMANN, Maria Barroso. Rio de Janeiro: Contracapa livraria, 2002. p. 51. 
outro em que Habermas analisa essa questão já é bastante sugestivo, ou seja, Inserção inclusão ou confinamento?

Por um lado, a cultura majoritária deve se soltar de sua fusão com a cultura política
geral, uniformemente compartida por todos os cidadãos; caso contrário, ela ditará $a$
priori os parâmetros dos discursos de auto entendimento. Como parte, não mais
poderá constituir-se em fachada do todo, se não quiser prejudicar o processo
democrático em determinadas questões existenciais, relevantes para as minorias. Por
outro lado, as forças de coesão da cultura política comum - a qual se torna tanto
mais abstrata quando mais forem as subculturas para as quais ela é o denominador
comum - devem continuar a ser suficientemente fortes para que a nação dos
cidadãos não se despedace: "O multiculturalismo, ao mesmo tempo que apoia a
perpetuação de vários grupos culturais dentro de uma mesma sociedade política,
também requer a existência de uma cultura comum... Membros de todos os grupos
terão de adquirir uma linguagem política e convenções de comportamento comuns
para poder participar eficientemente na competição por recursos e na proteção dos
interesses do grupo, assim como dos interesses individuais numa arena política
compartida. ${ }^{95}$

Ao falar em "competição por recursos", Habermas também esclarece que a interculturalidade, por mais dialógica que seja, não prescindirá de conflitos. Além disso, ao falar que a cultura majoritária deve se soltar da sua fusão com a cultura política geral, fica claro que, para Habermas, a inclusão se faz no espaço público dialógico, e não numa cultura específica.

De fato, as regras para esse diálogo não podem ser ditadas por apenas uma cultura. Ocorre que essa questão pressupõe outra, ainda mais complexa: Quem, então, ditará as regras? Essa pergunta, apesar de parecer pertinente, traz em seu bojo um vício típico do positivismo jurídico ocidental, que só consegue compreender o Direito enquanto um ato de ordem homogeneizante emanado de um grupo ilustrado. Necessariamente, para esta concepção, alguém, ou um grupo específico unitário (que, no final das contas, do mesmo modo é alguém), precisa outorgar o Direito. No entanto, essa concepção não é a única, pois o Direito pode ser não outorgado, mas construído, e esta concepção do Direito permitiria, ao contrário da anterior, não somente aceitá-lo como contribuição de muitos (e não mais de alguém), mas também admiti-lo como um resultado de negociações, negatividades e da crítica. ${ }^{96}$

Não acreditamos que as regras que orientarão os diálogos interculturais serão frutos de concessões de um Estado formado por uma cultura específica, nacional, nos moldes do que hoje temos no Brasil. Somente poderão existir regras simétricas para essa garantia dialógica se essas próprias regras forem objeto de lutas, de diálogos críticos e negociações que amiúde serão conflitivas e, é importante dizer,

\footnotetext{
${ }^{95}$ Op. Cit. p. 172.

${ }^{96}$ Enquanto krinein, do grego, no sentido de romper, separar.
} 
eternamente dinâmicas. A interculturalidade não pode ser vista como o fim da história das diferenças, mas única e exclusivamente como um campo equitativo de diálogo entre as diferenças. A estaticidade, a homogeneidade e a previsibilidade são características incompatíveis com um espaço intercultural, pois as próprias culturas e suas necessidades específicas são dinâmica, heterogêneas e imprevisíveis "por natureza".

Neste ponto surge outra questão fundamental: Se as regras do diálogo serão, elas mesmas, consensos formulados no curso de lutas interculturais, como essas lutas poderão proporcionar esse êxito pretendido se as culturas oprimidas não têm de fato, na América Latina (especialmente no Brasil), plena autonomia territorial ${ }^{97}$, nem acesso à educação e, ainda, estão submetidas ao "uso legítimo da força” pela cultura hegemônica que integra o aparelho estatal? A resposta a essa questão permanece sendo: as lutas.

$\mathrm{Na}$ América Latina temos exemplos muito interessantes de avanços e conquistas que demonstram que algum caminho já está sendo traçado e algumas etapas já foram superadas.

\begin{abstract}
No caso dos movimentos indígenas, que aqui queremos analisar com especial interesse, observa-se um processo de acumulação de experiências políticas e a consolidação de uma organização que poderia remontar ao período da Conquista ibérica, mas que contemporaneamente tem um marco histórico importante, na segunda metade do século $\mathrm{XX}$, quando das lutas contra a estrutura agrária do latifúndio e contra as diversas formas de exploração do trabalho do camponês, entre cujas referências mais importantes estão a Revolução Nacionalista Boliviana de 1952 e a Cubana de 1959. Deste período de grandes mobilizações, inclusive de lutas armadas, surgiram importantes organizações de camponeses-indígenas, com várias configurações, ora sindicais, como na Bolívia, ora estruturas legais comunitárias, associativas ou cooperativas no Equador, ora vinculadas a organizações eclesiásticas de base ou a partidos de esquerda na luta armada, como o que se viveu em América Central, ou inclusive a organizações não governamentais como o caso do Brasil. (...)

O interessante a ser destacado neste processo é que, em alguns países, a luta dos povos indígenas progressivamente superou o estágio de demandas por interesses imediatos para assumir-se como conflito por partilha de poder nas instituições formais do Estado, e inclusive na busca por autonomia nas suas comunidades, como um projeto político e um horizonte mais abstrato de emancipação política. Tal foi o caso, entre outros, do povo Miskito na Nicarágua da década de 80, assim como os zapatistas mexicanos no limiar do novo século XXI, o primeiro como experiência inaugural de autonomia, em acordo de paz com o Estado; o segundo como construção política à margem da ordem institucional, em territórios em que o Estado historicamente esteve, e assumiu continuar, ausente. ${ }^{98}$
\end{abstract}

\footnotetext{
${ }^{97} \mathrm{E}$ isso não significa independência, mas plena possibilidade de administrar todos os recursos.

98 URQUDI, Vivian Grace F. D. Descolonização e Estados Plurinacionais. $35^{\circ}$ Encontro Anual da Associação Nacional de Pós-graduação e Pesquisa em Ciências Sociais, 2011, Caxambu-MG. GT 26 Pensamento social latinoamericano. ANPOCS, 2011.
} 
O fato, contudo, que não podemos perder de vista, é que ainda estamos longe de um cenário efetivamente satisfatório, e que a interculturalidade não será uma dádiva obtida com eterna paciência. As lutas serão necessárias e um auxílio importante pode ser prestado pelas comunidades que já conseguiram avançar, pelas lideranças e intelectuais que se debruçam sobre essa questão, pois a análise crítica e clara dos obstáculos é, talvez, o primeiro passo a ser dado.

Sobre a necessidade de acesso aos meios materiais de luta como pressuposto para a construção de um espaço onde se possa dialogar simetricamente (o que nos interessa em termos de interculturalidade), Habermas, em A inclusão do outro, afirma:

\begin{abstract}
Em uma sociedade que é pluralista no que diz respeito à cultura e às visões de mundo, esse papel de fiador não pode ser transferido dos planos da formação política da vontade e da comunicação pública ao substrato aparentemente natural de um povo pretensamente homogêneo. Por trás de uma fachada como essa, iria esconder-se apenas a cultura hegemónica de uma parcela dominadora da sociedade. Por razões históricas, subsiste em muitos países uma fusão da cultura de maioria com determinada cultura política geral que arroga a si mesma ser reconhecida por todos os cidadãos, independentemente da origem cultural de cada um. (...) $O$ anseio por uma coexistência sob direitos iguais certamente sofre uma restrição segundo a qual as confissões e práticas a que se dispensa proteção não podem contradizer os princípios constitucionais vigentes (tal como entendidos na respectiva cultura política).

(...)

Presumo que as sociedades multiculturais só poderão manter-se coesas por meio de uma cultura política como essa, que já deu mostras de sua eficiência, se a Democracia for compensada não apenas sob a forma de direitos liberais à liberdade e direitos políticos à participação, mas também mediante o gozo profano de direitos sociais e culturais ao compartilhamento. Os cidadãos precisam poder experienciar o valor de uso de seus direitos também sob a forma da segurança social e do reconhecimento recíproco de formas de vida culturais diversas. A cidadania democrática e ligada ao Estado só exercerá força integrativa - ou seja, só promoverá solidariedade entre estranhos - quando der mostras de sua eficiência enquanto mecanismo pelo qual os pressupostos constitutivos das formas de vida desejadas possam de fato tornar-se realidade. ${ }^{99}$
\end{abstract}

Sobre o papel dos intelectuais, vale retomar a proposta de Dussel, que fala do intelectual situado entre as cultura ("intelectual das fronteiras"), analisada por ele dentro daquilo que denominou de projeto "trans-moderno":

Uma estratégia pressupõe um projeto. Denominamos projeto "trans-moderno" o intento libertador que sintetiza tudo o que temos dito. Em primeiro lugar, indica a afirmação, como autovalorização, dos momentos culturais próprios negados ou simplesmente desprezados que se encontram na exterioridade da Modernidade; que ainda têm sido deixado de fora da consideração destrutiva dessa pretendida cultura moderna universal. Em segundo lugar, esses valores tradicionais ignorados pela Modernidade devem ser o ponto de arranque de uma crítica interna, desde as

\footnotetext{
${ }^{99}$ Op. Cit. p.141/142.
} 
possibilidades hermenêuticas próprias da mesma cultura. Em terceiro lugar, os críticos, para sê-lo, são aqueles que vivendo a biculturalidade das "fronteiras" podem criar um pensamento crítico. Em quarto lugar, isso supõe um tempo largo de resistência, de amadurecimento, de acumulação de forças. ${ }^{100}$

A possibilidade desses intelectuais de fronteiras depende, sim, de possibilidades reais de ser diferente e de lutar por isso, mas a semente da própria vontade de resistir deverá ser plantada por práticas pedagógicas nos próprios oprimidos, e isso será analisado em capítulo específico, quando tratarmos da educação para os direitos humanos. Analisemos, então, o que pretendemos seja entendido por interculturalidade.

A preocupação que nos faz pensar a interculturalidade nasce diretamente das características daquilo que Dussel chamou "multiculturalismo altruísta". De fato, não existe uma construção teórica sistemática e convergente do que seria multiculturalismo, ainda que existam questões que, com alguma frequência, podem ser ditas como sendo típicas do multiculturalismo. ${ }^{101}$ Portanto, o que existe de consistente são construções reflexivas a respeito dessas questões, tais quais as levantada por Dussel, essas sim já desenvolvidas de maneira consistente o bastante para evidenciar que as propostas de diálogo intercultural não podem desconsiderar discursos que aparentemente, e só aparentemente, respeitam e promovem a diversidade cultural.

Como verificamos no curso deste tópico, a assimetria entre os interlocutores das culturas que precisam conviver em um mesmo espaço constitui o ponto central das críticas. Nesse sentido, nossa proposta de pensar a interculturalidade se preocupa menos com as disputas terminológicas e mais com as condições para que a convivência de culturas distintas seja possível sem genocídios e sem assimilações. A sugestão de pensarmos em termos de uma "interculturalidade", ao invés de tentar reconstruir tópicos que consideramos relevantes dentro do "multiculturalismo" permite, sim, a manipulação de um termo menos "contaminado" pelas construções problemáticas que Dussel analisou como sendo um "multiculturalismo altruísta". No entanto, repetimos, o principal objetivo não é uma patente terminológica, mas a construção de propostas que superem os problemas que, para nós, impedem o diálogo simétrico entre culturas.

\footnotetext{
100 Op. Cit.

101 A título de exemplo vale citar o canadense Will Kymlica analisa o multiculturalismo como se fosse uma espécie de mercado cultural onde os atores sociais poderiam escolher os melhores conhecimentos culturais. $\mathrm{O}$ multiculturalismo, assim, seria uma sistematização teórica com a pretensão de tratar a diversidade cultural dentro do pensamento liberal, ou seja, partindo da ideia de uma igualdade e de uma liberdade pressupostas como pontos de partida. Cf. KYMLICA, Will. Ciudadanía Multicultural: una teoría liberal de los derechos de las minorías. Barcelona: Paidós, 1996.
} 
Para que possamos caminhar nesse sentido e analisar as questões peculiares do diálogo intercultural e pensar como esse diálogo reflete no Direito e o que ele pode esperar do Direito, algumas premissas devem ser trabalhadas.

Ao pensarmos em interculturalidade devemos compreender que nenhuma cultura é estática e que o contato intercultural será repleto de rupturas e escândalos, como consignou Lévy-Strauss em nota supracitada. Do mesmo modo, devemos ter clara a impossibilidade de comparação valorativa de culturas, nem de suas particulares práticas e costumes.

Do mesmo modo, não há como desconsiderar que as culturas sempre estiveram em contato. Afirmar que existem etnias que ainda seriam "puras" é desconsiderar que a história do contato interétnico é uma história que independe da presença do Ocidente. Ora, se o "homem branco" não contatou determinada etnia, isso não significa que outra etnia não tenha tido com ela alguma história em comum. Exatamente por isso consideramos que a proposta da interculturalidade deve abandonar qualquer resquício de etnocentrismo, bem como a pretensão de onisciência, e no tópico anterior trabalhamos essas questões de forma mais detida.

A interculturalidade, assim, é a situação política onde as culturas poderiam dialogar de forma simétrica, sem esperar umas das outras a aceitação ou a concordância em relação às suas lógicas e práticas culturais. Habermas, em A inclusão do outro, afirma:

O direito à igualdade de respeito que cada um pode reivindicar também nos contextos vitais formadores da própria identidade nada tem que ver com a suposta excelência de sua cultura de origem, ou seja, com um desempenho que ocasione um agrado generalizado. ${ }^{102}$

Nessa linha, a interculturalidade demanda mais do que respeito; somente estará consolidada, do modo como pensamos, quando, para além do respeito, as culturas oprimidas puderem acionar de fato a autonomia para o uso, da maneira que lhes parecer melhor, dos instrumentos para se fazerem respeitar. E se fazer respeitar não pressupõe a titularidade e a legitimidade do uso da força, mas ter condições de fazer valer (e não necessariamente prevalecer) suas próprias lógicas discursivas.

Outro pressuposto fundamental da interculturalidade é o fato da permanente alteração dos consensos, pois, tal qual a vida, os consensos também se prestam ${ }^{102}$ Op. Cit. p.258. 
à convivência em determinado momento histórico, e por razões e sob as condições também históricas. Não pretendemos propor com a interculturalidade uma situação política a ser alcançada e monumentalizada como um herói de guerra numa praça construída para os pombos. A interculturalidade deve ser compreendida como uma situação política de permanente fluxo discursivo, de permanente diálogo intercultural e de permanentes conflitos que, do nosso ponto de vista, se alcançada a simetria dialógica, poderão ser resolvidos às custas de bem menos vida, de menos sangue do que os conflitos que ocorrem no seio dos pseudodiálogos que atualmente o Estado nacional trava com os seus súditos da "colônia".

A interculturalidade pressupõe, portanto, sair da dimensão da tolerância altruísta, que admite apenas o que no outro existe de comum ou administrável em mim, e caminhar para outras dimensões de respeito que permitirão e farão sentido como dimensões de convivência.

\section{3- O OUTRO EM MIM E AS LUTAS POLÍTICAS POR DIREITOS}

Como afirmamos e ficou claro no tópico anterior, para que possamos pensar interculturalidade fundamentalmente devemos levar em conta a presença complexa da figura do outro. A proposta de reconhecimento desse outro de modo a evitar experiências de desrespeito exige, por consequência, tanto a possibilidade de acesso aos meios políticos suficientes para se fazer respeitar como a compreensão do motivo pelo qual esse reconhecimento é tão difícil quando se está em questão o contato entre culturas muito diferentes umas das outras. A questão do acesso aos meios para se fazer respeitar foi analisada no tópico anterior, onde nos esforçamos para evidenciar a importância dessa questão para a garantia de simetria dialógica. Neste tópico, então, analisaremos a relevância do reconhecimento das diferenças para o convívio por parte da própria cultura hegemônica.

Tivemos a oportunidade de verificar nas referências teóricas da Antropologia a presença quase que unânime da compreensão de que o contato com culturas distintas dificilmente ensejará um apreço no observador; muito pelo contrário, a regra é o espanto. Ainda que existam experiências de impressionismos exóticos, como relatou Sérgio Buarque de Holanda em sua obra Visão do Paraíso: os motivos edênicos no descobrimento e colonização do Brasil, essas experiências aparentemente ocorrem nas 
hipóteses em que o eu metafísico se vê projetado no outro. O que nos interessa é a projeção, a sensação do outro em mim (enquanto eu real) e a reação política de recusa desse outro estranho.

Sérgio Buarque de Holanda explica que a visão edênica das terras americanas se deu em razão de uma identidade que as praias, o clima, o nu, a ingenuidade destes trópicos tinha com a descrição bíblica do paraíso. Além disso, sobre a terra descoberta ainda não existia a ânsia do progresso, a ânsia do eu real no outro, mas unicamente a excitação de se estar diante de um lugar vivo segundo as descrições metafísicas.

Sempre os mesmos elementos que, durante toda a Idade Média, se tinham apresentados como distintivos da paisagem do Éden ou que pareciam denunciar sua proximidade imediata: primavera perene ou temperatura sempre igual sem a variedade das estações que se encontra no clima europeu, bosques frondosos de saborosos frutos e prados férteis, eternamente verdes ou salpicados de flores multicoloridas e olorosas, cortados de copiosas águas (usualmente quatro rios, segundo o padrão bíblico), ora em lugar elevado e íngreme, ora numa ilha encoberta em que mal se conhece a morte ou a enfermidade ou mal algum.

Desses elementos, sabemos que muitos viriam encontrar os navegantes quando aportassem nas terras mais chegadas à linha equinocial, em particular o das folhas sempre verdes. E não lhes pareceria de má filosofia o concluir que, existindo nelas algumas dessas virtudes, não haveriam de faltar todas as outras mais, que pudessem completar o panorama edênico. ${ }^{103}$

Por mais complexa e distante que possam parecer essas ideias, é exatamente essa projeção de um eu metafísico sobre o outro real que fez com que indígenas do mundo todo colocassem na Carta da Terra o seguinte dispositivo: 59. Os Povos Indígenas reconhecem e valorizam a busca de proteção à Biodiversidade, mas rejeitam serem incluídos como parte da diversidade inerte, preservado por razões científicas ou folclóricas. E ainda: 92. Não devemos permitir que o turismo seja utilizado para diminuir a nossa cultura. Eles chegam em nossas comunidades, veem nossa gente como se fosse parte de um zoológico.

É muito comum, ainda hoje, que legiões de adolescentes deslocados ocidentais procurem comunidades indígenas para terem experiências de vivência na mata, com rituais étnicos e outras práticas que encantam sujeitos oriundos de uma cultura vazia. Não existe nenhum compromisso de troca cultural, mas simplesmente de uso, de consumo

${ }^{103}$ HOLANDA, Sérgio Buarque de. Visão do Paraíso: os motivos edênicos no descobrimento e colonização do Brasil. São Paulo; Companhia das Lestras, 2010. p. 262. 
da cultura alheia, como forma de se forjar um eu impossivel no Ocidente no outro real indígena (e também africano).

Nesse sentido, o que nos move a refletir sobre o outro em mim nada tem a ver com práticas simuladas, dissimuladas, mercantilizadas por uma espécie de turismo, que não promove a troca experiencial da convivência, mas única e exclusivamente a troca capital típica das relações de consumo. O que queremos analisar é como, e se seria possível, pensarmos sinceramente em uma expansão do humano culturalmente considerado a partir do contato com outro humano situado em uma cultura distinta. Em outros termos, e considerando as premissas que nos orientaram até aqui, pretendemos analisar como o estranhamento e o choque cultural - inevitáveis nos contatos interétnicos - podem promover essa expansão do humano e como os direitos humanos entram nessa cena, não mercadológica, mas sensível, como orientação dos discursos que brotarão do diálogo entre essas culturas.

Este tópico específico diz respeito à dimensão psicanalítica da luta por reconhecimento, em direta relação com a noção de integridade psíquica desenvolvida por Axel Honneth em sua obra Luta por reconhecimento: a gramática moral dos conflitos sociais $^{104}$ e a noção de estranhamento desenvolvida por Sigmund Freud em seu texto $O$ Estranho. ${ }^{105}$

Nessa linha, e partindo da premissa desenvolvida no capítulo anterior acerca do Direito oficial, e como este se encontra configurado - um instrumento de verticalização do etnocentrismo ocidental - o que pretendemos analisar é como (ou se) o Direito pode assumir no espaço intercultural um papel de garantia da integridade psíquica honnethiana buscando uma ligação com a ideia do "estranho" analisada por Freud.

Apesar da abordagem que Freud faz das sociedades que ele chama de primitivas, ${ }^{106}$ ou seja, apesar de analisar essas sociedades com uma acentuada carga de

\footnotetext{
${ }^{104}$ Op. Cit.

105 FREUD, S. O Estranho (1919). In. Sigmund Freud, Vol. XVII - "Histórias de uma neurose infantil e outros trabalhos". Rio de Janeiro: Imago Editora.

106 No texto Totem e tabu (1913), especificamente no tópico "Horror ao incesto" Freud diz: Há homens vivendo em nossa época que, acreditamos, estão muito próximos do homem primitivo, muito mais do que nós, e a quem, portanto, consideramos como seus herdeiros e representantes diretos. Esse é o nosso ponto de vista a respeito daqueles que descrevemos como selvagens ou semi-selvagens; e sua vida mental deve apresentar um interesse peculiar para nós, se estamos certos quando vemos nela um retrato bem conservado de um primitivo estágio de nosso próprio desenvolvimento. Mais à frente, no tópico "Tabu e ambivalência emocional", diz que os povos primitivos submetem-se às proibições como se fossem coisa natural e estão convencidos de que qualquer violação terá automaticamente a mais severa punição. Diz ainda: Ouvimos histórias dignas de fé de como qualquer violação involuntária de uma dessas proibições é de fato automaticamente punida. Um transgressor inocente, que, por exemplo, tenha comido um animal proibido, cai em profunda depressão, prevê a morte e em seguida morre de verdade. Essas proibições dirigem-se
} 
evolucionismo cultural, ${ }^{107}$ o que interessa particularmente de Freud é a abordagem que faz no texto $O$ Estranho (1919), exatamente no ponto em que toca na relação existente entre o estranhamento e o retorno de um conteúdo reprimido no sujeito que estranha, o que, na realidade, acaba por conferir vida a crenças ou impulsos reprimidos.

Importante esclarecer aqui que o recurso que faremos a Freud é absolutamente limitado, pois não desenvolvemos nesta pesquisa um estudo sistemático da psicanálise freudiana, havendo muitas outras questões para serem analisadas em conjunto. O que queremos sugerir com a leitura do texto $O$ Estranho é exclusivamente a necessidade de atenção com aspectos psicanalíticos do contato interétnico, ou seja, a necessidade de considerar que o diálogo intercultural não se fará entre culturas abstratamente consideradas, mas entre indivíduos culturalmente situados, e isso faz toda diferença. Ainda que as demandas culturais carreguem traços fortemente coletivos, o fato de que somente existem culturas por existirem sujeitos de cultura não pode ser esquecido. Uma coisa é defender o sujeito como entidade suprema (noção de sujeito de direito) e desconsiderar por completo que inúmeras culturas têm no coletivo o foco de preocupação. Outra coisa é defender a cultura enquanto dado abstrato e desconsiderar o fato de que qualquer cultura pressupõe sujeitos que podem tanto primarem pelo individualismo, como pelo coletivismo.

Assim, levando em conta a relevância de Freud para a teoria crítica e em especial a forma pela qual abordou a experiência do estranhamento, analisamos a seguir a relevância do momento do estranhamento como uma experiência intercultural e intersubjetiva. Isso porque para a democracia e para a construção de um modelo de Estado intercultural, essa experiência deve ser vivida em algum momento de modo que a integridade psíquica, enquanto expressão de real liberdade, não reste tolhida pelo Direito que, como se encontra hoje configurado, apresenta alta carga de etnocentrismo.

O primeiro ponto que merece atenção é a relação que o Direito oficial tem com quem detém o poder. Seja rei, papa, líder espiritual, presidente de uma república, enfim, sempre haverá uma íntima ligação entre a cultura do líder e a cultura significada no Direito oficial. Ainda que pensemos na figura do "povo", também nesse caso é possível flagrarmos uma relação intracultural entre o tal "povo" e o Direito. Se pensarmos em

principalmente contra a liberdade de prazer e contra a liberdade de movimento e comunicação. Em alguns casos têm um significado compreensível e visam claramente a abstinências e renúncias. Mas em outros casos o motivo central é inteiramente incompreensível; estão relacionadas com detalhes triviais e parecem ser de natureza puramente cerimonial.

${ }^{107}$ Sobre evolucionismo cultural conferir capítulo anterior e também: MORGAN, L. Ancient Society. Arizona Press, UNIVE. 1985 e TYLOR, E. Primitive Culture. Editora Cambrige, USA. 2010. 
"povo" para Rosseau, a ideia seria a totalidade dos cidadãos franceses. Mas se pensarmos em povo em países, por exemplo, da América Latina e da África, a pluralidade étnica impede uma configuração simplista dessa categoria em termos rosseaunianos. Assim, quando pensamos em "povo", nas atuais configurações de Estado e de determinação de titularidade de poder, inevitavelmente vamos flagrar uma confusão entre essa ideia de "povo" e o fato da aristocracia que, no mundo atual, foi deposta pela plutocracia, o que justifica a inserção na presente pesquisa dos questionamentos referentes à indústria cultural e a sociedade para consumo.

Essa relação entre o poder e o Direito oficial ocorre pelo fato de o Direito ser um instrumento do poder, e um instrumento absolutamente útil, pois por ser tópico e líquido em seus conteúdos, permite sua manipulação retórica para servir a interesses imediatos de dominação. Nesse sentido, ao menos nas tradições ocidentais, a abertura do Direito para o pluralismo humano se dá apenas "em termos"; em outras palavras, nos termos de quem detém o poder.

A principal característica do Direito ocidental, e isso fica bastante evidente em contextos pluriculturais, é a carga colonizadora dos ordenamentos jurídicos. Quando Boaventura de Sousa Santos chama nossa atenção para os resquícios coloniais ${ }^{108}$ que ainda existem na América Latina, fica evidente que as características coloniais podem ser detectadas até mesmo pelo próprio colonizador, não sendo preciso grande esforço intelectual para se chegar a essa constatação. Assim, e retomando o ponto que nos animou a escrever este capítulo, o Direito enquanto produto cultural ainda traz em seus princípios, na América Latina, intenções ou resquícios inconscientes de colonização. ${ }^{109}$

O motivo pelo qual o Direito acaba por se operacionalizar narcísica e autisticamente, ou seja, pela consideração da incapacidade de se proporcionar nos responsáveis pela definição dos termos do Direito (e aqui entra o papel do discurso, que será melhor analisado no capítulo seguinte) é o que nos animou a conferir o título ao presente tópico, ou seja, a experiência de encontro do outro em mim.

\footnotetext{
${ }^{108}$ Cf. SANTOS, Boaventura de Sousa. La reinvención del estado y el estado plurinacional. Publicação da Alianza Interinstitucional CENDA, CEJIS, CEDIB. Bolivia, 2007. Texto disponível no seguinte sítio eletrônico: < http://bibliotecavirtual.clacso.org.ar/ar/libros/coedicion/boavent/cap\%205.pdf> Acesso em 12 de fevereiro de 2011.

${ }^{109}$ CAMPOS, Edemilson A. A tirania de Narciso - alteridade, narcisismo e política. São Paulo: Annablume: FAPESP, 2001. O vício/mal só é possível dentro de uma nova ordem: a ordem instaurada por Narciso. Nessa nova ordem, movido pelo amor-próprio narcisista, o homem busca ordenar o todo tomando a si mesmo como o centro. Julgando-se o rei da criação e de todo o universo, o homem busca assumir o lugar da divindade, reduzindo todos a seu próprio interesse. p.94.
} 
Fixada essa premissa, ou seja, compreendido o etnocentrismo que marca o Direito ocidental (que, repita-se, hoje se encontra mundializado quase que de maneira absoluta, ao menos no que se refere às relações econômicas que, por sua vez, definem a maioria das relações humanas no capitalismo), qualquer relação intercultural de submissão ao Direito posto será uma experiência de imposição, e não de respeito. Isso por que o Direito oficial do Estado-nação legitima o uso da força de um grupo específico que detém o poder para a tão buscada "coesão social" que, em outros termos, é uma espécie de "seja igual a mim" ou "queira o que eu quero"; e qualquer desvio de comportamento (seja ele social, seja ele cultural) justificará o uso da força para a coesão pretendida, que, em verdade, é mais narcísica do que justa.

O fato da imposição do Direito oficial (por meio dos discursos de uma cultura hegemônica) somado à legitimação do uso da força exige a discussão da ideia do Direito como fruto de um contrato social. Ainda que pudéssemos questionar se um contrato pode ser assim considerado se nas negociações existir apenas um monólogo, a questão central é que, se valendo da legitimação do uso da força, ainda em uma relação dialógica, o grupo hegemônico tem muito mais condição de impor suas vontades ao outro grupo interlocutor. Nesse sentido, a própria noção de contrato social precisa ser submetida às considerações interculturais que pretendemos desenvolver aqui, pois, de outro modo, a vinculação da cultura despossuída dos instrumentos de uso da força a esse contrato não será fruto de uma vontade livremente manifestada, ou de um consenso livremente negociado, mas sim de um receio de violência.

Não pretendemos, aqui, fazer uma digressão intelectual até o dia em que, inexistindo Direito, o primeiro contrato social foi firmado. O que nos interessa é o tempo presente; o que nos interessa é como serão de hoje em diante as relações humanas entre culturas distintas no Brasil e, quiçá, no mundo. Nesse sentido, o que hoje podemos considerar é que existe, no mesmo mundo, um grupo detentor de direito e de fato do poder e da força física e outro grupo que não detém e que aguarda novos Direitos a serem construídos interculturalmente no curso da história. E aqui nos dispusemos a esclarecer o que tem impedido a construção e a compreensão da noção de Direitos, enquanto correlação de ordens jurídicas, bem como de um Direito cujo sentido seja decorrência de discursos interculturais simétricos.

Nesse sentido, o Direito compreendido estritamente nos termos hobbesianos de contrato social seria uma espécie de "prudência", de receio de violência, e, em um discurso que pretende questionar e criticar as estruturas de dominação instauradas 
para o desrespeito, a aceitação do Direito enquanto prudência nada mais seria do que uma reverência à fatalidade do poder concentrado em um grupo. Em uma passagem de Luta por Reconhecimento Axel Honneth comenta:

\begin{abstract}
Para qualquer um que parta da ficção metodológica de um estado de natureza entre os homens, coloca-se fundamentalmente o mesmo problema teórico: como os indivíduos, em uma situação social marcada por relações de concorrência recíproca, chegam a uma ideia de "direitos e deveres" intersubjetivos? Para Hegel, as respostas que foram dadas a essa questão nas diversas tradições do direito natural possuem todas elas a mesma propriedade negativa: a "determinação do direito" é sempre trazida, de alguma maneira, de fora, na medida em que o ato de fechar o contrato é posto ou como preceito de prudência (Hobbes) ou como um postulado da moral (Kant, Fichte). ${ }^{110}$
\end{abstract}

Uma compreensão do Direito que o considere como fruto de uma negociação livre entre sujeitos de cultura ou como uma mágica sensação moral de respeito ao diferente, sem dúvida alguma fecha os olhos para as condições reais do contato intercultural, bem como para as necessidades reais dos "negociantes" desse contrato. Isso porque a existência de relações pré-contratuais de desigualdade e estranhamento impedem indiscutivelmente a igualdade e a boa vontade dos "contratantes" desde os primeiros acertos até o momento da realização do objeto do "contrato".

A inércia do Direito oficial diante das possibilidades históricas de construção de um espaço público dialógico para as culturas, onde a pretensão de uma moral universal cederia espaço para a proposta honnethiana de reconhecimento, fica bastante clara quando se reflete acerca do direito à igualdade.

Toda vez que se pensa em igualdade inevitavelmente se intui algum referencial "universal". A igualdade ocidental de raiz iluminista é a distribuição quantitativa do bem que se pretende distribuir, uma espécie de compreensão kantiana da moral, e com isso se passa ao largo da questão da igualdade qualitativa que, atualmente, tem sido pensada em termos de reconhecimento e de direito à diferença. $\mathrm{E}$ mais ainda, o parâmetro de universal não costuma ser o resultado de uma negociação livre e plural, mas o resultado de algo que se tem plena convicção de que seja bom e belo, ou seja, o próprio ego daquele que, em posse do poder, se impõe como paradigma. O desejo que não se conforma ao desejo do poder soberano é extraordinário, estranho e deve ser punido, reprimido ou, ao menos, desconsiderado.

Essa ausência de consciência, às vezes, parece mesmo uma consciência desconstrutiva, ou, em outras palavras, mantenedora de um poder fundado

\footnotetext{
${ }^{110}$ Op. Cit. p. 84.
} 
numa ética egocêntrica, bem distante da proposta de Axel Honneth acerca das éticas comunitaristas:

\begin{abstract}
Nesse sentido, a abordagem da teoria do reconhecimento, na medida em que a desenvolvemos até agora na qualidade de uma concepção normativa, encontra-se no ponto mediano entre uma teoria moral que remonta a Kant e as éticas comunitaristas: ela partilha com aquela o interesse por normas as mais universais possíveis, compreendidas como condição para determinadas possibilidades, mas partilha com estas a orientação pelo fim da autorrealização humana. ${ }^{111}$
\end{abstract}

A auto realização humana é um dos pontos centrais da teoria de Axel Honneth, na medida em que a luta por reconhecimento não teria como objetivo apenas um reconhecimento forjado na esfera exógena do amor, do direito e da solidariedade, mas também, e essencialmente, no campo intrapsíquico dos sujeitos que empreendem essa luta. Honneth distingue as lutas sociais nascidas de uma experiência de desrespeito moral e as lutas que não decorreriam desse desrespeito considerado em sua teoria, como, por exemplo, as lutas por sobrevivência econômica. O desrespeito considerado por Honneth não se refere a simples interesses de reprodução de grupos ou classes, mas a experiências morais ligadas à "integridade psíquica" dos sujeitos humanos, que deveria levar em conta um anseio por um campo dialógico universal e que, contudo, considerasse também as éticas comunitaristas (ou, retomando a idéia já citada de Gofredo Telles Júnior, a natureza quântica da humanidade). Essa distinção, aliás, decorre do movimento que a própria teoria crítica tem feito no sentido de expandir a reflexão crítica para além dos horizontes da luta entre capital e trabalho. É nesse sentido que Honneth afirma:

Os modelos de conflito que começam pelos interesses coletivos são aqueles que
atribuem o surgimento e o curso das lutas sociais à tentativa de grupos sociais de
conservar ou aumentar seu poder de dispor de determinadas possibilidades de
reprodução; (...) Pelo contrário, um modelo de conflito que começa pelos
sentimentos coletivos de injustiça é aquele que atribui ao surgimento e o curso das
lutas sociais às experiências morais que os grupos sociais experimentam perante a
denegação do reconhecimento jurídico ou social. Ali se trata da análise de uma
concorrência pelos bens escassos; aqui, porém, da análise de uma luta pelas
condições intersubjetivas da integridade pessoal. ${ }^{112}$ A questão da integridade psíquica está ligada, na luta por reconhecimento de Honneth, à ideia de liberdade, bem como nos faz desenvolver nossas reflexões em diálogo com a Psicanálise. Honneth sugere que a liberdade não pode se referir simplesmente à ausência de coerção ou influência externa, devendo significar também a ausência de bloqueios internos.

\footnotetext{
${ }^{111}$ Op. Cit. p. 271.

112 Op. Cit. p. 261
} 
Neste ponto gostaríamos de retomar a preocupação de Mariátegui citada no tópico anterior, a respeito do índio que passaria a explorar outros índios. Quando decidimos analisar este aspecto e dialogar com as questões referentes à integridade psíquica dos sujeitos de cultura, como explicamos no tópico anterior, não desconsideramos a relevância das lutas pela sobrevivência fisiológica, pois isso é relevantíssimo; o que queremos é deixar evidente que para além dessas questões existem outras tantas, e considerá-las neste trabalho é imprescindível, pois nossa proposta de diálogo intercultural simétrico depende de todas essas questões simultaneamente.

Ao levar em consideração a importância de ausência de bloqueios internos Honneth toca em uma questão bastante cara às ideias que estamos desenvolvendo no presente trabalho. Como deixamos claro, partimos do pressuposto de que o Direito é, por natureza, um instrumento de repressão (ainda que instrumento de repressão de conteúdos deixados de lado após um diálogo justo pelo mais legítimo processo constituinte interculturalmente dialógico). Nesse sentido, pensar no Direito enquanto um sistema de regras de convívio exige a consideração de que a definição dessas regras, para que pensemos esse convívio como algo realmente fundado na noção de liberdade, não pode se travestir em bloqueios psíquicos impostos por uma cultura a outra. Ao contrário, as regras definidas deverão assumir a função democrática de proporcionar a diferença cultural e fixar limites para que uma cultura não bloqueie, mas promova, a integridade psíquica do outro sujeito de cultura com o qual convive.

Essa promoção, como veremos a seguir, não se dá pela proteção abstrata de um ordenamento jurídico que evita a exposição da diferença, mas por um Direito que garanta essa exposição e o contato de todos com ela através do convívio sensível e, por vezes, escandalizador. É exatamente a partir dessas considerações/constatações, que a ideia de um universal abstrato precisa ruir, exigindo, na sequência, novas formas de se pensar a convivência humana como forma de promoção da integridade psíquica pela expansão do humano a partir do encontro do outro em mim.

A identidade subjetiva a partir da identidade coletiva é uma noção dificilmente compreendida pela cultura capitalista ocidental. Adorno tratou do tema no texto Relação entre Sociologia e Psicologia, onde comenta que: (...) Os seres humanos não são capazes de se reconhecer na sociedade, nem de reconhecer esta neles, pois estão 
alienados entre si e em relação ao conjunto. ${ }^{113} \mathrm{O}$ atual estágio da cultura capitalista impede esse reconhecimento no outro e tenta proibir esse reconhecimento.

Essa alienação do sujeito em relação ao seu coletivo é uma característica que na obra Luta por reconhcimento Honneth considerou como ausência de liberdade de se auto-realizar: (...) a liberdade de auto-realização depende de pressupostos que não estão à disposição do próprio sujeito humano, visto que ele só pode adquiri-la com a ajuda de seu parceiro de interação. ${ }^{114}$ Se o ocidente não se encontra em condições de proporcionar essa experiência de liberdade, o primeiro passo para uma interculturalidade possível é a ausência de repressão aos contatos fundados nessa experiência.

Essa experiência de identificação secundária é uma experiência de compreensão do outro que, se situada dentro da concepção freudiana de estranhamento, pode fornecer dados importantes para a proposta de um espaço em que seja possível a interculturalidade. A mediação da liberdade individual pela atividade de outros sujeitos livres é exatamente a constatação da liberdade enquanto experiência que, na realidade, se dá pela convivência entre sujeitos livres, mas livres na cultura. E para a conclusão que pretendemos, sujeitos livres são sujeitos culturalmente livres, aqui compreendidos todos os aspectos econômicos, sociais, políticos e psíquicos da cultura. Nessa linha, não há como pensarmos em experiência inter-relacional, em identificação secundária em um espaço intercultural, se não considerarmos a imprescindibilidade do convívio entre sujeitos de cultura distintas e livres.

Ocorre que esse convívio, ao menos inicialmente, será uma experiência de estranhamento, de espanto, de escândalo. O fim dessa experiência que pode ser traumática e justifica plenamente, pois o que emergirá como resultado é o reconhecimento do outro em $\mathrm{mim}$. No entanto, o que pretendemos refletir, é como essa experiência pode ser um meio que, considerando a relevância do fim, não seja instrumental demais ao ponto de se consubstanciar em mais um exemplo de barbárie racionalizada do nosso tempo. Antes de pensar em como se empreender experiências de estranhamento, importante analisarmos como Freud desenvolveu essa ideia.

Certamente, a opção pela repressão do que se mostra estranho ao nosso "paladar cultural" é quase que natural, na medida em que o estranho nos causa

\footnotetext{
${ }^{113}$ ADORNO, T.W. De la relación entre sociologia y psicologia. In: ADORNO, Theodor W. Actualidad de la filosofia. Barcelona: Paidós, 1991. p. 139.

${ }^{114}$ Op. Cit. p 273.
} 
repulsa. No entanto, precisamos considerar que essa repressão só é justificada politicamente pelo fato de estar legitimada pelo Direito cujo sentido é conferido por discursos emanados de uma só cultura e, nesse sentido, precisamos pensar em como manipular esse Direito (ou melhor, esses discursos) no sentido de evitar a repressão do estranho como consequência imediata da experiência de estranhamento.

Nesse sentido, e retomando a idéia freudiana do estranhamento, o que chama a atenção nessa abordagem é exatamente a dimensão da natureza dos conteúdos reprimidos, ou seja, a familiaridade que representam perante e dentro do ser humano que os transporta e os experimenta inconscientemente.

A proposta de Freud se desenvolve a partir da seguinte proposição: (...) o estranho é aquela categoria do assustador que remete ao que é conhecido, de velho, e há muito familiar. Como isso é possível, em que circunstâncias o familiar pode tornar-se estranho e assustador, é o que mostrarei no que se segue. ${ }^{115}$

Freud inicia a sua análise acerca do tema comparando os diversos significados que encontra em dicionários e em diversas línguas para o termo que em alemão seria unheimlich, passível de contraposição ao termo heimlich. Entre vários significados e aplicações distintas do termo heimlich, duas formas de utilização do termo são destacadas por Freud, quais sejam: 1- o que é familiar e agradável; 2- o que está oculto e que se mantém fora de vista.

Freud comenta que normalmente o termo unheimlich é utilizado como contrário do primeiro significado de heimlich, ou seja, como o que não é familiar e agradável. A noção de unheimlich como algo que não mais está oculto não é a forma mais usual de aplicação do termo. Neste ponto Freud faz referência a Schelling, para quem unheimlich seria tudo o que deveria ter permanecido oculto, mas veio à luz.

Freud analisa principalmente a experiência do estranho a partir da obra O Homem da Areia, de Ernst Theodor Amadeus Wilhelm Hoffmann, conferindo especial ênfase ao complexo de castração consubstanciado no medo do personagem principal de perder os olhos. No entanto, e é isso que nos interessa particularmente, para esclarecer a proposta de Schelling, Freud analisa alguns exemplos individuais de estranheza, sendo o exemplo mais esclarecedor o referente à epilepsia. Freud diz: (...) $A$ estes acrescenta o estranho efeito dos acessos epiléticos e das manifestações de insanidade, porque excitam no espectador a impressão de processos automáticos e

\footnotetext{
${ }^{115}$ Op. Cit. p. 238.
} 
mecânicos, operando por trás da aparência comum de atividade mental. ${ }^{116} \mathrm{E}$ ainda: $O$ efeito estranho da epilepsia e da loucura tem a mesma origem. O leigo vê nelas a ação de forças previamente insuspeitas em seus semelhantes, mas ao mesmo tempo está vagamente consciente dessas forças em remotas regiões do seu próprio ser. ${ }^{117}$

Freud faz distinção entre o estranhamento objeto de comentário e o estranhamento diante do que é feio ou incomum em obras literárias, em especial obras infantis (já que se refere aos conteúdos reprimidos na infância). Diz que nesses casos a experiência do estranhamento não ocorre em razão de uma espécie de certeza de que os eventos que poderiam causar estranhamento (como objetos inanimados que falam, cantam etc.) estariam apenas no conto de fadas. Existe uma certeza de que aquilo não ocorre e não ocorrerá. Nessa linha, Freud se concentra nos casos clínicos que analisou, onde o conteúdo reprimido acaba sendo, de uma forma ou de outra, encontrado na realidade.

Na sequência, Freud diz:

\begin{abstract}
Neste ponto vou expor duas considerações que, penso eu, contêm a essência deste breve estudo. Em primeiro lugar, se a teoria psicanalítica está certa ao sustentar que todo afeto pertencente a um impulso emocional, qualquer que seja a sua espécie, transforma-se, se reprimido, em ansiedade, então, entre os exemplos de coisas assustadoras, deve haver uma categoria em que o elemento que amedronta pode mostrar-se ser algo reprimido que retorna. Essa categoria de coisas assustadoras construiria então o estranho; e deve ser indiferente a questão de saber se o que é estranho era, em si, originalmente assustador ou se trazia algum outro afeto. Em segundo lugar, se é essa, na verdade, a natureza secreta do estranho, pode-se compreender por que o uso lingüístico estendeu das Heimlich [homely (doméstico, familiar)] para o seu oposto, das Unheimlich (p.243); pois esse estranho não é nada novo ou alheio, porém algo que é familiar e há muito estabelecido na mente, e que somente se alienou desta através do processo de repressão. Essa referência ao fator da repressão permite-nos, ademais, compreender a definição de Schelling (p.242) do estranho como algo que deveria ter permanecido oculto mas veio à luz. ${ }^{118}$
\end{abstract}

Nessa linha, o estranhamento não seria o contato com algo desconhecido, mas com algo familiar, porém reprimido. A barbaridade desses conteúdos se justifica, pois tudo o que é reprimido o é em razão de escolhas culturais, verticalmente impostas, por exemplo, às crianças que não possuem, na tenra idade, condições de optarem por uma existência repleta de possibilidades, restando-lhes apenas a existência repleta de regras dentro de uma única possibilidade, qual seja, cumpri-las. Inicialmente, as regras são transferidas pela relação parental e, na sequência, após o início da formação do superego, na relação com instituições culturais.

\footnotetext{
${ }^{116}$ Op. Cit. p. 244.

${ }^{117}$ Idem. p. 260.

${ }^{118}$ Op. Cit. p. 258.
} 
A ideia freudiana de que o estranhamento seria decorrência do retorno de um conteúdo reprimido, do "retorno em si", a partir da percepção da existência real desse conteúdo (fenômeno do duplo), é particularmente interessante para as democracias que não assumem o compromisso com experiências dialógicas nos momentos de criação e atualização das regras. Isso na medida em que os sistemas psíquicos de referências culturais dos legisladores, dos responsáveis pela "ordem e pelo progresso", dificilmente conseguirão evitar a experiência da estranheza diante do outro culturalmente distinto e da íntima vontade de fazer sumir essa experiência que, devemos reconhecer, é bastante desconfortável e ameaçadora.

Em contextos pluriculturais essa preocupação com o momento legiferante e com o momento hermenêutico é fundamental para a proposta de diálogos interculturais. Ademais, no que diz respeito à construção de uma ordem jurídica universal, valem as mesmas considerações.

Um exemplo claro dos efeitos dessa ausência de diálogo prévio que impacta o Direito e as decisões judiciais é a ausência de reconhecimento das formas tradicionais indígenas de representatividade coletiva, como no caso que citamos na introdução em relação ao Mandado de Segurança Coletivo. A ausência de disposição do Poder Judiciário para criar uma possibilidade constitucional de participação política dos povos indígenas (pois a matéria envolvida era de caráter político, além de ter ligação com o direito à saúde) traduz esse estranhamento diante da organização social típica da cultura indígena e uma justificativa positivista com base no Direito literalmente considerado.

Nessa linha, quando Honneth fala da necessidade do outro para a real liberdade de auto-realização, como expressão da integridade psíquica, poderíamos concluir que a ausência de liberdade de realização dos povos indígenas seria decorrência direta da sua exclusão do espaço público nos momentos precedentes à elaboração das leis e nos momentos de sua atualização pela hermenêutica. Como afirma Alicia Lisondo: $A$ subjetividade se constrói na intersubjetividade. ${ }^{119}$

A relevância de um estranhamento prévio ao momento de positivação das leis se justificaria pelo fato de que, nos momentos posteriores, o poder já estaria "concentradamente distribuído" e, exatamente por isso, o "outro estranho" seria vítima direta de um dos mais eficientes instrumentos de repressão do que é estranho e, portanto,

\footnotetext{
${ }^{119}$ LISONDO, Alicia Beatriz D. Na cultura do vazio, patologias do vazio. Ver. Brasileira de Psicanálise. Vol. 38 (2). P.335-358, 2004.
} 
não desejado: o Direito oficial (e no caso em questão, o Direito emanado de um ego assustado)!

Neste caso, o estranhamento anterior às leis, além de poder proporcionar experiências de estima social honnethiana, poderia gerar também um ambiente muito mais propício ao respeito oriundo do Direito, já que o outro seria percebido antes da elaboração das regras, que o desconsiderariam se não tivesse aparecido no espaço público e, o que é essencial, assustado quem na ocasião detinha mais signos de poder. No entanto, como afirmamos acima, não pretendemos regredir até o momento em que o homem saiu da anomia, pois, em verdade, temos dúvidas se esse estágio um dia sequer existiu. O que nos interessa, por ora, é como o Direito oficial poderá ser reconstruído ou atualizado na história, como serão as construções legislativas e hermenêuticas nos próximos capítulos da história da humanidade e, nessa linha, como sugerimos no tópico anterior e desenvolveremos no próximo capítulo, pensamos que as lutas serão essenciais. 


\section{CAPÍTULO 3 \\ DISCURSO, DIÁLOGO E HERMENÊUTICA INTERCULTURAL}

\section{1 - A QUESTÃO DO DISCURSO}

Como esclarecemos na introdução deste trabalho, nossa preocupação com o discurso jurídico como sendo o espaço, o lugar para pensarmos a interculturalidade no Direito, se deve à constatação de que o Direito é um fenômeno típico de qualquer sociedade, variando em seus aspectos de acordo com os discursos que cada cultura se vale para conferir sentido a esse Direito. Em nossos estudos verificamos que a elevação do sujeito de direito à condição de principal destinatário de direitos, a dimensão universal dos direitos humanos, a nação e o Estado de Direito soberano e titular do uso legítimo da força, não eram resultados do Direito abstratamente considerado, mas de discursos que, investidos de poder, conferem estatuto jurídico a essas ideias.

$\mathrm{Na}$ mesma linha, a proposta de manter o foco no discurso deixa bastante evidente que o que pretendemos com a proposta de intercuturalidade é sugerir a possibilidade de convivência de culturas distintas (com discursos e necessidades distintas) sob a égide de um mesmo conjunto de normas garantidoras desse convívio, tendo em vista a ideia de Herrera Flores, citada em outras oportunidades neste trabalho, de um universal a ser construído de forma dialógica e sem a desconsideração da possibilidade de conflitos.

Esse esclarecimento inicial - e nesta parte do trabalho - é importante pelo fato de permitir um corte fundamental - diríamos essencial, pois evitará confusões entre o que estamos querendo falar quando sugerimos a interculturalidade ao invés do pluralismo jurídico e do multiculturalismo. Sobre o multiculturalismo teceremos comentários no próximo tópico, cabendo, contudo, alguns comentários sobre o pluralismo jurídico neste momento.

Nossa preocupação reside na necessidade de convivência dialógica em um mesmo espaço que, exatamente por ser o mesmo espaço, comportará questões que exigirão consensos, e não simplesmente uma coexistência tolerante. O pluralismo jurídico representa uma construção da mais alta relevância para os direitos humanos, pois no curso do seu movimento crítico (e no Brasil temos como referência os estudos de Antonio Carlos 
Wolkmer) ${ }^{120}$ avançou de forma admirável no esclarecimento de que não apenas existem diferenças culturais e socioeconômicas que não encontram eco no Direito oficial, mas, principalmente, que esses grupos não considerados de forma efetiva pelo Direito oficial organizam esquemas paralelos de juridicidade de modo a alcançarem possibilidades mínimas de sobrevivência e convivência comunitária.

Boaventura de Sousa Santos flagrou esse sistema jurídico paralelo ao oficial em uma favela do Rio de Janeiro em estudo realizado na década de 1970. Boaventura de Sousa Santos atribui a essa favela o codinome "Pasárgada" e descreveu um cenário de juridicidade bastante desenvolvido.

Em Pasárgada a associação de moradores cedo passou a ser conhecida pela sua intervenção nas relações sociais entre vizinhos, sobretudo naquelas que envolvessem direitos sobre a habitação ou a terra, numa intervenção que, aliás, não era, em termos gerais, inédita na comunidade, uma vez que continuava de modo mais sistemático e menos precário a intervenção anteriormente assumida por outras instituições comunitárias e nomeadamente pelos leaders locais.

(...)

Tais relações têm uma estrutura homológica das relações jurídicas. No entanto, à luz do direito oficial brasileiro, as relações desse tipo estabelecidas no interior das favelas são ilegais ou juridicamente nulas, uma vez que dizem respeito a transações sobre terrenos ilegalmente ocupados e a construções duplamente clandestinas. Dentro da comunidade, contudo, tais relações são legais e como tal são vividas pelos que nela participam; (...) A associação de moradores transformou-se, assim, gradualmente num forum jurídico, à volta do qual se foi desenvolvendo uma prática e um discurso jurídicos - o direito de Pasárgada. ${ }^{121}$

Como se verifica pela descrição que Boaventura de Sousa Santos faz da comunidade de Pasárgada e do sistema paralelo de juridicidade, o direito oficial e o Direito de Pasárgada coexistem num mesmo espaço geopolítico. A explicação de Boaventura de Sousa Santos dialoga perfeitamente com a definição que Wolkmer apresenta de "pluralismo jurídico":

Deste modo, o pluralismo legal cobre não só práticas independentes e semiautônomas, com relação ao poder estatal, como também práticas normativas oficiais/formais e práticas não-oficiais/informais. A pluralidade envolve a coexistência de ordens jurídicas que define ou não relações entre si. O pluralismo pode ter como meta práticas normativas autônomas e autênticas geradas por diferentes forças sociais ou manifestações legais plurais e complementares reconhecidas, incorporadas e controladas pelo Estado. ${ }^{122}$

\footnotetext{
${ }^{120}$ Cf. WOLKMER, Antonio Carlos. Introdução ao Pensamento Jurídico Crítico. 5.ed. São Paulo: Saraiva, 2006.

${ }^{121}$ SANTOS, Boaventura de Sousa. O discurso e o poder: ensaio sobre a sociologia da retórica jurídica. $2^{\mathrm{a}}$ reimpressão. Porto Alegre: Sergio Antonio Fabris Editor. 1988. p.13/14.

122 Op.cit. p. 188.
} 
De fato, podemos vislumbrar a existência de situações em que coexistem em um mesmo espaço geopolítico mais de um sistema jurídico de soluções de conflito (e Pasárgada é um exemplo disso). É interessante a preocupação de Boaventura de Sousa Santos em conceituar o que se entende por "Direito", de modo que não reste dúvidas de que seu objeto de pesquisa esteja sendo analisado realmente em um contexto de pluralismo jurídico. ${ }^{123} \mathrm{O}$ interessante, contudo, é que antes de apresentar sua definição própria de Direito, Boaventura de Sousa Santos retoma uma discussão extremamente importante para a presente pesquisa, que é a discussão que foi travada na Antropologia Jurídica acerca não da definição de Direito, mas do método de definição de Direito. Para essa abordagem, Boaventura de Sousa Santos retoma o debate entre Gluckman e Bohannan nos seguintes termos:

\begin{abstract}
A controvérsia, que se prende com a questão, mais ampla, do etnocentrismo, consiste em saber se é legítimo (Gluckman) ou ilegítimo (Bohannan) usar na análise de outras sociedades e culturas conceitos, como, por exemplo, o conceito de direito, que são originalmente conceitos-folk (conceitos populares ou étnicos) da sociedade e cultura a que pertence o antropólogo. ${ }^{124}$
\end{abstract}

A par do debate Gluckman-Bohannan, Boaventura de Sousa Santos apresenta o seu modo peculiar de encarar a questão, afirmando que há um mérito a ser atribuído a Bohannan pela denúncia do etnocentrismo, mas que essa denúncia tem uma carga de idealismo ao pretender a apropriação dos denominados "conceitos-folk" por sujeitos de outras culturas. Boaventura de Sousa Santos diz que:

O que critico em Bohannan não é a denúncia do etnocentrismo (tantas vezes "ingênuo"), que é meritória e importante; é antes o idealismo da denúncia, ao seprar o processo de construção conceitual do modo de produção do conhecimento antropológico no seu todo, cujas implicações imperialistas são muito mais vastas e envolvem o processo global do trabalho científico, mesmo o daqueles que decidem usar (em texto escrito em língua "ocidental") as categorias e os conceitos "nativos". 125

Essa posição de Boaventura de Sousa Santos retoma a discussão proposta também por Roy Wagner, como analisamos no capítulo 2, acerca do papel limitado (pois inventivo) do antropólogo no estudo analítico de outras culturas.

\footnotetext{
${ }^{123}$ Op. Cit. p. 72. Com este propósito concebe-se como direito, o "conjunto de processos regularizados e de princípios normativos, considerados justificáveis num dado grupo, que contribuem para a criação e prevenção de litígio e para a resolução destes através de um discurso argumentativo, de amplitude variável, apoiado ou não pela força organizada".

${ }_{124}^{124}$ Op. Cit. p. 66.

${ }^{125}$ Op. Cit. p. 67.
} 
A preocupação com o método de se compreender o que para outra cultura é Direito é, para o nosso trabalho, mais relevante do que a própria busca por um conceito abrangente de Direito que justifique a tese de que existem no Brasil (e na América Latina) situações concretas de pluralismo jurídico, pois além de não negarmos o pluralismo (é suficiente sairmos dos nossos "gabinetes"), pensamos que não será uma espécie de conceito abrangente de Direito que permitirá a compreensão de que de fato existe pluralismo jurídico. É o em si do pluralismo que, além de se auto-afirmar, exigirá dos juristas (sociólogos, antropólogos, filósofos, políticos e outros críticos do Direito) a preocupação de se debruçar sobre as necessidades de um Direito que, enquanto conjunto de normas voltadas ao convívio, administre tanto a coexistência desses vários sistemas nos pontos em que haja conexões de finalidades da ação, quanto garanta e oriente o diálogo necessário para a convivência nos pontos em que não haja conexões entre os fins que orientam as ações, mas apenas entre o caminho ou o espaço necessário para que cada um atinja o seu fim particular.

Assim, ainda que consideremos relevantíssima a proposta do pluralismo jurídico num mundo irrecusavelmente plural, a questão que nos toca particularmente é, recorrendo ao exemplo da Pasárgada, a seguinte: Quando o Estado (ou um proprietário particular) dono do terreno ocupado pela comunidade de Pasárgada quiser remover essa comunidade sob a alegação de ocupação irregular, qual Direito será aplicado? E ainda, na inevitável hipótese de ser aplicado o Direito oficial, qual discurso irá prevalecer: o discurso da irregularidade da ocupação ou o discurso da finalidade social da propriedade? Outrossim, também na muito provável hipótese de prevalecer o discurso do Estado ou do proprietário particular, o que a comunidade de Pasárgada poderá fazer a não ser se curvar à decisão e ocupar outra área (e assim sucessivamente, suportando a ausência de segurança habitacional e suas consequências)? Essa pergunta foi formulada nesses termos por termos nos referido à obra de Boaventura de Sousa Santos, mas poderia ser aplicada com a mesma exatidão para o caso dos atingidos por barragens ${ }^{126}$ e dos povos indígenas que lutam contra o agronegócio e as usinas nucleares atualmente no Brasil e, mais especificamente, contra o projeto da usina de Belo Monte.

Essas perguntas esclarecem que a proposta do pluralismo jurídico se situa em campo delimitado pelas fronteiras da "não interferência" entre Direitos. Enquanto as decisões de Pasárgada se resumem a decidir conflitos internos à comunidade, tanto faz o

\footnotetext{
${ }^{126}$ Outras informações disponíveis no seguinte sítio eletrônico: <www.mabnacional.org.br>, Acesso em 19
} de outubro de 2011 . 
Direito que será aplicado nos casos concretos. Não extrapolando os limites de Pasárgada, o Direito oficial, o Estado oficial e a "sociedade oficial" toleram tanto a existência de Pasárgada como as práticas dos seus moradores. No entanto, a partir do momento em que o caso concreto envolve moradores de Pasárgada e moradores que vivem "sob a égide do Direito oficial" (ou direito do asfalto, como preferiu Boaventura), a figura muda de cor. Por isso que quando pensamos em pluralismo, pensamos em situações de juridicidade que não envolvem consensos decorrentes de culturas distintas. Em Pasárgada não havia uma cultura distinta, mas o abismo entre a situação dos moradores de Pasárgada e dos moradores pertencentes de fato à "comunidade dos incluídos" é tão grande que podemos verificar não uma cultura distinta propriamente dita, em termos étnicos, mas uma noção de pertencimento coletivo que reflete de tal modo na lógica discursiva de Pasárgada que nos permite considerar esse caso como um caso didático para o que pretendemos desenvolver a seguir.

O que nos interessa nesse caso, portanto, é que o pluralismo jurídico tem um foco específico, e o foco que pretendemos conferir em nosso estudo sobre interculturalidade é exatamente o espaço do conflito entre lógicas discursivas. Boaventura de Sousa Santos trabalhará esse conflito de forma mais detida em sua proposta de uma hermenêutica diatópica, quando explica a noção de "topos" como sendo lugares comuns retóricos mais abrangentes de determinada cultura. ${ }^{127}$ A hermenêutica especificamente será objeto do tópico seguinte, mas por ora vale a referência à noção de "topos".

É importante ficar claro que não estamos falando simplesmente de discursos, mas de lógicas discursivas, ou seja, de discursos que, além de serem distintos, partem de "topoi" distintos. O conflito entre lógicas discursivas que nos interessa não é o conflito entre vizinhos moradores de Pasárgada ou entre sócios de uma sociedade por ações constituída conforme as regras da Lei 6.404/76. O conflito que nos interessa é o que nasce entre o discurso de um morador de Pasárgada acerca da legitimidade de sua posse sobre determinada parcela de terra e o discurso do proprietário constante da escritura pública acerca dessa mesma legitimidade; ou, mais particularmente, o discurso etnodesenvolvimentista indígena e o discurso desenvolvimentista dos investidores capitalistas em relação à legitimidade da construção da usina de Belo Monte. Em suma, o discurso do opressor e do oprimido.

\footnotetext{
${ }^{127}$ Op. Cit. p.30.
} 
Enquanto o pluralismo jurídico analisa e esclarece a existência de mais de um direito com lógica discursiva própria, se foca no estudo das particularidades dessas lógicas discursivas e sugere o respeito dessas lógicas próprias, a proposta de interculturalidade estuda as condições para se garantir um diálogo equilibrado voltado para a solução pacífica de situações em que lógicas discursivas distintas entram em conflito ou tentam desautorizar o acesso umas das outras a bens fundamentais para a dignidade coletiva e individual que comungam de uma e outra lógica.

É, portanto, no momento em que surgem conflitos, que também surge a necessidade de consensos e, para tanto, um diálogo equilibrado. Nessa linha, o que propomos é que o Direito apto a regular e garantir de fato simetria entre as relações sociais em contextos plurais deveria ser fruto de escolhas determinadas por consensos decorrentes de diálogos equilibrados, seja no momento da fixação das primeiras regras de diálogo, seja no momento de realização hermenêutica e decisória do que, dialógica e discursivamente, restasse definido como sendo Direito.

A propriedade é um fato comum tanto para o Direito oficial, como para o Direito das comunidades indígenas e também para o Direito de Pasárgada. A questão está no sentido que é dado a essa propriedade que, de caso a caso, de cultura para cultura, será significada por lógicas discursivas distintas: serão essas lógicas que assumirão a feição de "direito de propriedade".

Tércio Sampaio Ferraz Junior, analisando as características e justificativas do saber dogmático do Direito, afirma que, além de uma função pedagógica, esse saber tem uma função de desencargo para o jurista (juiz, advogado, legislador), pois permite que esse jurista (...) não seja obrigado a tomar consciência de todo o repertório argumentativo a utilizar em cada caso. ${ }^{128}$ (...) E mais à frente elabora um exemplo extremamente didático a respeito dessa noção de que o Direito é, de fato, um conjunto de possibilidades discursivas:

(...) Por exemplo, muito embora a doutrina tenha consciência da multiplicidade de sentidos, problemas e dados empíricos referentes à família, ao fornecer-lhe um sentido técnico (grupo fechado de pessoas, composto de pais e filhos e, para efeitos limitados, parentes, unidos pela convivência e afeto, numa mesma economia e sob a mesma direção) (...) isola um aspecto da realidade - a família, tal como ela se apresenta em alguns grupos sociais mormente na tradição ocidental - estabelecendo um corte em relação aos demais dados antropológicos - agrupamentos em que a relação pai-mãe-filho é secundária, formas comunitárias em que a família não é a célula primária etc. $^{129}$

\footnotetext{
${ }^{128}$ Op. Cit. P.61.

${ }^{129}$ Op. Cit. p.62.
} 
Ainda que essa concepção tenha alguma utilidade dentro das necessidades da dogmática jurídica para o momento de decisão, apresenta-se para nós, ou melhor, dentro das nossas inquietações, como um sério problema em sociedades pluriculturais, como é o caso do Brasil. Roque de Barros Laraia ${ }^{130}$ descreve a concepção de família de uma comunidade Jê do Alto Xingu, onde os indígenas dessa comunidade consideram que apenas uma cópula não é suficiente para dar origem a um ser humano; por essa razão, seriam necessárias várias relações sexuais. Caso a mulher tenha relações com vários homens, todos serão vistos como pais da criança e, principalmente, cumprirão socialmente com esse papel. Como subsumir essa concepção na concepção de família do Direito oficial?

No caso da obra $O$ discurso e o poder, especificamente, Boaventura de Sousa Santos chama a atenção para o fato de que especialmente no Direito oficial do estado capitalista ocorre um elevado grau de institucionalização da função jurídica, apontando a profissionalização e especialização dos profissionais (Boaventura chama esse processo de "divisão do trabalho jurídico"), tendo em vista a criação de um monopólio discursivo (pois técnico e especializado), reduzindo aquilo que o autor chamou em sua obra de "espaço retórico do Direito".

Nesse sentido, consideramos o momento de atribuição de sentido ao Direito e às suas normas como foco das nossas reflexões. Como verificamos, desde a escolha das normas a serem positivadas até o ato de interpretação e de aplicação, as lógicas discursivas orientam o sentido do Direito. O salto paradigmático a ser dado diz respeito ao diálogo prévio a esses atos de positivação e realização do Direito, de modo que o discurso jurídico seja apenas um reflexo do discurso intercultural, e não de um discurso etnocêntrico que se pretende legítimo. Esperar do Direito, abstratamente considerado, alguma forma de garantia de direitos é acreditar que o Direito se encontra para além dos homens, para além das culturas, para além dos conflitos sociais de natureza ética e moral. Habermas, em $A$ inclusão do outro, tece interessante crítica a essa concepção:

(...) Se a justiça realmente pudesse mover-se livremente no âmbito de uma ordem de valores flexível, como afirma Teubner, e se dependesse de reduzir princípios e demarcações de objetivos, normas e valores ao denominador comum dos "bens jurídicos" e ainda "ponderá-los" uns em relação aos outros, então os discursos jurídicos assumiriam na verdade o papel de discursos paternalistas e substituintes de

\footnotetext{
${ }^{130}$ Op. Cit.
} 
um auto-entendimento ético-político, do qual os cidadãos estariam sendo privados $(\ldots)^{131}$

De fato, a participação na vida política enquanto espaço de trocas, conflitos e consensos discursivos, não pode ser preterida em favor de uma concepção de Direito cujo sentido é um privilégio conferido a uma elite ilustrada, iluminada pela luz de um sol que só brilha para essa própria elite. Essa é uma questão fundamental para a interculturalidade.

O momento da positivação, ou escolha das normas, é de alta relevância para o nosso trabalho, mas enquanto momento de definição das regras que garantirão o equilíbrio do diálogo. Exatamente por isso destinaremos um tópico específico para a questão do equilíbrio dialógico. Não obstante a relevância do momento da positivação das normas que constituirão o ordenamento jurídico e, no nosso caso, que garantirão a simetria necessária para o diálogo intercultural, voltamos a nossa atenção para o momento hermenêutico, pensando não apenas os seus obstáculos naturais à interculturalidade, mas também as vias possíveis de superação desses obstáculos.

A seguir, no tópico 3.2, analisaremos a questão do equilíbrio dialógico. No tópico 3.3 analisaremos os problemas do momento hermenêutico e posteriormente, no capítulo 4, analisaremos, a partir de uma proposta de educação para os direitos humanos, as vias possíveis de solução dos impasses de uma hermenêutica intercultural.

\section{2 - O DIÁLOGO INTERCULTURAL}

De tudo o que dissemos até aqui podemos tirar algumas conclusões. A primeira delas é que a proposta de diálogo intercultural, para ser pensada em termos jurídicos, deve ter como foco o discurso que confere sentido ao Direito e o concretiza. A segunda conclusão, não menos importante, diz respeito à necessidade de se trabalhar no Estado-juiz (imediatamente) e em toda sociedade (através de um processo mais longo e demorado) a sensibilidade diante da opressão e da barbárie com uma educação estruturada para a promoção dos direitos humanos.

A segunda conclusão terá os seus desdobramentos abordados no capítulo 4. Neste tópico analisaremos os desdobramentos da primeira conclusão, com foco no

\footnotetext{
${ }^{131}$ Op. Cit. p. 377.
} 
problema fundamental da ausência de equilíbrio entre os interlocutores do diálogo intercultural. Roberto Cardoso de Oliveira tece interessantes ponderações a esse respeito ao analisar, a partir de Habermas e Apel, o diálogo interétnico.

\begin{abstract}
(...) Não será difícil imaginar que em termos cognitivos estaria ocorrendo o que os hermeneutas chamam de "fusão de horizontes", onde o tipo de "verdade" alcançável pela comunidade intercultural seria produto de uma "negociação" entre as partes. Nesse sentido, o pressuposto ético fundamental é que essa negociação só pode ter lugar no âmbito de relações simétricas, o que significa dizer: livres e democráticas, capazes de estabelecer, numa primeira etapa, regras claras, acordadas por consenso explícito entre os interlocutores de ambos os lados. O não ferir a ética começaria por não romper as regras preliminares de entendimento. Desde logo, em lugar de confronto étnico - algo corrente nos programas desenvolvimentistas - haveria de se esperar um encontro entre interlocutores imbuídos menos de verdades e mais de pontos de vista. ${ }^{132}$
\end{abstract}

$\mathrm{Na}$ mesma linha de preocupação, Dussel comenta a assimetria dialógica dentro da relação colonial:

\begin{abstract}
Neste contexto se efetuou uma crítica à posição ingênua que definiu o diálogo entre as culturas como uma possibilidade simétrica multicultural, idealizada em parte, e onde a comunicação pareceu ser possível para seres racionais. A "Ética do Discurso" adotava essa posição otimista. Um Richard Rorty, e com diferenças um A.McIntyre, mostrava ou a completa incomensurabilidade de uma comunicação impossível ou sua extrema dificuldade. De todas as maneiras se prescindia de situar as culturas (sem nomeá-las em concreto nem estudar sua história e seus conteúdos estruturais) em uma situação assimétrica que se originava por suas respectivas posições no sistema colonial mesmo. A cultura ocidental, com seu "ocidentalismo" óbvio, situava todas as outras culturas como mais primitivas, pré-modernas, tradicionais, subdesenvolvidas. ${ }^{133}$
\end{abstract}

Essa preocupação é fundamental para a proposta do diálogo

intercultural. $\mathrm{O}$ fato da desigualdade entre os interlocutores repercute diretamente na força (no peso, no valor) do discurso desses interlocutores. Inúmeras vezes ouvimos indígenas questionando: Para quê fazem essas audiências públicas se, no fim, nós sempre estamos errados e de nada valem nossas opiniões?

Também Boaventura de Sousa Santos confere especial atenção a essa problemática, analisando o processo (...) pelo qual a argumentação do agente (sócio

\footnotetext{
132 Op. Cit.

${ }^{133}$ Op. Cit. Texto em espanhol (original): En este contexto se efectuó una crítica a la posición ingenua que definía el diálogo entre las culturas como una posibilidad simétrica multicultural, idealizada en parte, y donde la comunicación pareciera ser posible para seres racionales. La "Etica del Discurso" adoptaba esta posición optimista. Un Richard Rorty, y con diferencias un A.McIntyre, mostraba o la completa inconmensurabilidad de una comunicación imposible o su extrema dificultad. De todas maneras se prescindía de situar a las culturas (sin nombrarlas en concreto ni estudiar su historia y sus contenidos estructurales) en una situación asimétrica que se originaba por sus respectivas posiciones en el sistema colonial mismo. La cultura occidental, con su "occidentalismo" obvio, situaba a todas las otras culturas como más primitivas, pre-modernas, tradicionales, subdesarrolladas.
} 
politicamente) forte se transforma na argumentação (retoricamente) forte ${ }^{134}$. Na obra $O$ discurso e o poder Boaventura de Sousa Santos aponta a amplitude tópico-retórica do Direito de Pasárgada como sendo uma característica inclusiva e de mais facilitada adaptação histórica e social (ausente no Direito do Estado capitalista), chamando também a atenção para o fato de que as desigualdades no interior do círculo argumentativo abriria campo para a devastação do interlocutor mais fraco, chamando a atenção também para o monopólio dos meios de comunicação de alto potencial persuasivo.

\begin{abstract}
A questão da igualdade no interior do círculo argumentativo transcende em muito o domínio da retórica jurídica e põe-se a nível da retórica geral, sobretudo numa época em que os meios de comunicação social monopolizam os recursos de maior potencial persuasivo. Daí que a sociologia da retórica não possa constituir-se à margem das teorias da comunicação social. ${ }^{135}$
\end{abstract}

Não superadas essas desigualdades, o diálogo que poderia ser efetivamente intercultural, ao invés de se constituir como prática emancipadora, assumirá o papel de campo fértil para uma nova forma de violência, a simbólica ${ }^{136}$. No curso da história política latino-americana presenciamos projetos bem sucedidos na luta por essa necessária igualdade comunicativa ensejadora de discursos equivalentes, pressuposto para um diálogo justo entre lógicas discursivas distintas. Pablo Gonzáles Casanova analisa as conquistas obtidas pelos novos movimentos sociais ${ }^{137}$ :

\footnotetext{
${ }^{134}$ Op. Cit. P. 91.

135 Op. Cit. p.92.

${ }^{136}$ Boaventura comenta a esse respeito em sua obra $O$ discurso e o poder: À medida em que se avoluma $e$ consolida a desigualdade dos habitantes do espaço retórico, faz sentido reconstruir criticamente a retórica como uma nova forma de violência, ao lado da violência burocrática e da violência física - a violência simbólica. (p.96).

137 Acerca dos movimentos sociais ver, CASANOVA, Pablo Gonzáles. Op. Cit. Em suas formas mais avançadas os novos movimentos colocam uma alternativa distinta à estatista revolucionária ou à reformista, e também à anarquista e libertária. Nem lutam para reformar o Estado, nem brigam para tomar o poder do Estado em uma guerra de posições e movimentos, nem pretendem criar aldeias ou regiões isoladas dirigidas por suas comunidades ao estilo daqueles anarquistas do Peru ou da Catalunha que declararam que em seu povoado havia desaparecido o Estado, e mais cedo que tarde o Estado acabou com eles. A proposta dos zapatistas está combinando as antigas formas de resistência das comunidades com sua articulação a maneira de redes muito variadas. As redes não somente incluem distintos povos indígenas que antes se enfrentavam entre si e que agora atuam conjuntamente para resistir e governar, mas também muitas minorias, etnias ou povos das mesmas províncias ou países, e de regiões como mesoamérica ou indoamérica, e até outras maiores e mais longínquas com as quais ao menos entram em comunicação por via eletrônica. As redes também incluem os camponeses que não se identificam por uma cultura ou língua distinta da nacional. Incluem os trabalhadores, os estudantes, os intelectuais, as populações marginais urbanas e outros chamados novos movimentos como os de gênero, os ecologistas, os de devedores e aposentados, e em geral os dos empobrecidos, marginalizados, excluídos, desempregados, e ameaçados de extinção.

E ainda sobre os novos movimentos sociais, também a citação precisa de Vivian Urquidi. Op. Cit. A teoria social tem chamado aos movimentos sociais com foco na identidade, de Novos Movimentos Sociais (Laraña \& Gusfield, 1994; Gohn, 1997; Laraña, 1999; Santos, 2005) porque suas lutas giram em torno de demandas subjetivas que estão, muitas vezes, no foro íntimo das identidades de gênero ou das culturas e relações cotidianas. São movimentos que envolvem categorias diversas da sociedade, como etnia, geração, ou meio
} 
A formação de redes e organizações autônomas coloca uma nova alternativa de luta com crescentes capacidades de enfrentar o sistema dominante enquanto articule e reestruture as forças heterogêneas que não somente dão um valor primordial à autonomia necessária, mas também à dignidade, irrenunciável, de pessoas e coletivos. Essas colocações não somente incluem um novo uso dos meios eletrônicos e de massas, mas também comunicações presenciais. Através de uns e outros a leitura e o diálogo coletivos combinam os espaços de reflexão, criação e atuação de pequenos grupos com os atos de massas com discursos dialogais. Ademais, transmitem o projeto em distintas formas de raciocinar, sentir e expressarse, isto é, em uma mistura de gêneros literários e de artes pedagógicas e retóricas que não permite separar os discursos histórico-políticos dos filosófico-científicos unidos, sem perder muito do que se está vivendo e criando. $\underline{\mathrm{O} \text { conjunto de um }}$ fenômeno de diálogo integral, ou de pensar-sentir-fazer, que desde sempre existiu, adquire um relevo especial como se suas articulações fossem em grande medida intuídas e deliberadas. A comunicação interativa e intercultural torna-se possível por um respeito ao diálogo das crenças, das ideologias, e das filosofias ligado à descolonização da vida cotidiana e dos "momentos estelares" da comunidade crescente, esboço de uma humanidade organizada (...). ${ }^{138}$ (grifamos)

Isso que Casanova chama de "discursos dialogais entre as massas" num ambiente de colonialismo é essencial para a troca de percepções a respeito do interlocutor que, hoje, monopoliza o discurso. Enrique Dussel a esse respeito desenvolve uma reflexão que em hipótese alguma pode ser desconsiderada, a proposta de um diálogo Sul-Sul.

Dussel analisa a importância de um diálogo intercultural transversal, ou seja, de um diálogo entre as "periferias", retomando a ideia comentada acima de "centro e periferia"; um diálogo que parta do movimento feminista e vá até as lutas antirracista e anticolonialista.

O diálogo intercultural presente não é só, nem principalmente, um diálogo entre os apologistas de suas próprias culturas, que tentariam mostrar aos outros as virtudes e valores de sua própria cultura. É, antes de tudo, o diálogo entre os criadores críticos de sua própria cultura (intelectuais da "fronteira", entre a própria cultura e a Modernidade). (...) Não obstante, ademais, não é o diálogo entre os críticos do "centro" metropolitano com os críticos da "periferia" cultural. É, antes de tudo, um diálogo entre os "críticos da periferia”, um diálogo intercultural Sul-Sul, antes de passar ao diálogo Sul-Norte. ${ }^{139}$

ambiente, que tratam de sujeitos sem identidades fixas, sem projetos para a totalidade da sociedade, nem têm centralidade de ação política. Enfim, são movimentos cuja estrutura organizacional e horizonte de luta, cujos sujeitos antagônicos e projetos, cujas doutrinas ou práticas são heterogêneos e, por isso, são distintos dos movimentos com perspectiva classista.

${ }^{138}$ Op. Cit.

${ }^{139}$ DUSSEL. Tradução livre do original: El diálogo intercultural presente no es sólo ni principalmente un diálogo entre los apologistas de sus propias culturas, que intentarían mostrar a los otros las virtudes y valores de su propia cultura. Es ante todo el diálogo entre los creadores críticos de su propia cultura (intelectuales de la "frontera", entre la propia cultura y la Modernidad). No son de los que meramente la defienden de sus enemigos, sino los que primeramente la recrean desde los supuestos críticos que se encuentra en su propia tradición cultural y de la misma Modernidad que se globaliza. La Modernidad puede servir como un catalizador crítico (si la usa la mano experta del crítico de la propia cultura). Pero, además, 
De fato, esse diálogo Sul-Sul é essencial para a construção de bases materiais e discursivas sólidas para o enfrentamento necessário para a conquista da simetria dialógica que é objeto de nossas reflexões, e os novos movimentos sociais na América Latina têm sido responsáveis por avanços importantíssimos na conquista dessa força discursiva no espaço público de convivência. Casanova comenta que:

\begin{abstract}
Os novos movimentos e muitas das populações que são suas bases de apoio sabem que o controle do Estado chega aos partidos políticos e aos meios de comunicação, de alimentação, de saúde, de educação, de intimidação, de persuasão, e implica uma luta pela alternativa que se coloque o problema da moral coletiva como uma das forças mais importantes para a resistência pacífica dos povos, uma resistência armada de valor e inteligência, mais que de fuzis, e disposta a negociar sem sucumbir, construindo forças de tal modo articuladas e autônomas que imponham uma política de transição para um mundo capaz de sobreviver e de viver. Nesse terreno os novos movimentos, se reencontram com o único dos anteriores, o " 26 de Julho", que conseguiu subsistir não somente frente à ofensiva que o capital neoliberal e oligopólico desataram nos últimos vinte anos, mas também frente ao assédio e bloqueio que o governo dos Estados Unidos lhe impôs há meio século. ${ }^{140}$
\end{abstract}

Vivemos em um cenário em que os meios de comunicação monopolizam os recursos de maior potencial persuasivo, e o fazem dentro da lógica sórdida da indústria cultural, ou seja, criando desejos e imediatas angústias e, em seguida, disponibilizando fórmulas de solução que criam dependências e clientelismos. Diante desse cenário, ainda que existam exemplos de êxito, fica evidente que também há, ainda, muito a se conquistar e se construir, pois a forma mais segura de se opor ao poder e permanecer firme nesse movimento de oposição e de conquista de equilíbrio é minando as estruturas desse poder que, na América Latina, permanece com feições coloniais.

Temos claro, como dissemos em outro momento deste trabalho, que a igualdade real no diálogo intercultural não será fruto de concessões da parte mais forte que, no caso dos povos indígenas, é o Estado, colonial, gamonal (em referência a Mariátegui), detentor do uso legítimo da força. Esperar uma dádiva dessa envergadura seria esperar que Narciso abandonasse o seu reflexo. A conquista dessa igualdade, dessa simetria, será fruto de muitas lutas, estratégias, invasões e pilhagens contra as bases que sustentam, hoje, os discursos dos interlocutores mais fortes.

O que importa ponderar, nessa linha, é que as bases a serem atingidas são muitas e, dependendo da estratégia adotada, pode ser que o resultado seja mais

no es siquiera el diálogo entre los críticos de "centro" metropolitano con los críticos de la "periferia" cultural. Es antes que nada un diálogo entre los "críticos de la periferia", un diálogo intercultural Sur-Sur, antes que pasar al diálogo Sur-Norte.

${ }^{140}$ Op. Cit. 
violência. No entanto, como estamos refletindo a respeito de um diálogo fundado nos direitos humanos, nosso esforço é no sentido de pensar vias que, ainda que conflitivas, evitem um saldo negativo de vidas. Compreendemos que nesse campo de discussão tal proposta é bastante complexa, pois não basta vontade de apenas um dos lados da luta. Uma via interessante e que nos parece plenamente possível seria a desobediência civil ${ }^{141}$ que, no nosso cenário de colonialismo econômico, político e cultural, teria algum impacto se se articulasse em termos de uma "greve de consumo", pois de fato os vários pontos de enfrentamento têm uma raiz primitiva num modo específico de produção. No entanto, e precisamos pensar sobre isso, como poderíamos nós, citadinos presos em apartamentos mal visitados pela luz do sol, deixar de consumir qualquer gênero extraído da terra?

Nesse cenário de impasses, uma conclusão clara é que o que permitirá de fato um diálogo intercultural simétrico, livre da ameaça ou do uso efetivo da força pelo interlocutor hegemônico para fazer valer seu discurso é a possibilidade dos oprimidos acessarem de forma suficiente os antídotos ou os instrumentos para a criação dos antídotos desse poder. O que embasa, hoje, o poder que define, por exemplo, a construção da usina de Belo Monte, é uma lógica discursiva fundada em argumentos econômicos. Um dos antídotos ao poder econômico é a estagnação (do consumo, da produção ou do fornecimento de matéria prima). No entanto, no Brasil, onde os povos indígenas ocupam parcela expressiva do território nacional, nenhum tipo de desobediência civil pode ser articulado para impedir Belo Monte, ou ao menos colocar a questão numa pauta dialógica simétrica. Essa dificuldade de enfrentamento ocorre pelo fato de que, ainda que esses povos habitem grande parte do território nacional, não têm autonomia de fato sobre esses territórios. Se tivessem essa autonomia, com acesso irrestrito não só ao solo, mas também ao subsolo e seus recursos minerais, o acesso às patentes de seus conhecimentos tradicionais, um movimento bem articulado de estagnação da produção entre todos os povos poderia ser um antídoto realmente eficaz (e pacífico - até onde pudesse ir a razão) contra o discurso hegemônico que justifica Belo Monte. Atingido ou ameaçado em suas estruturas, o poder que antes colonizava se verá compelido a dialogar e encontrar um ponto de consenso.

\footnotetext{
${ }^{141}$ A busca por soluções pacíficas de conflitos humanos é tema de preocupação central para os direitos humanos. Para uma análise mais estendida do tema vale consultar a obra de Henry David Thereau, $A$ Desobediência Civil (THEREAU, Henry D. A Desobediência Civil. Porto Alegre: L\&PM Editores, 1997) e, a partir de uma perspectiva internacional, vale consulta à obra Direitos humanos e não-violência, de Guilherme Assis de Almeida, especialmente o primeiro capítulo, onde é trabalhada a noção de "nãoviolência" (ALMEIDA, Guilherme Assis. Direitos Humanos e não-violência. São Paulo: Atlas, 2001.)
} 
Assim, o acesso aos bens materiais para o enfrentamento eficaz no discurso hegemônico é requisito essencial para o diálogo intercultural, e é por isso que a questão da terra nos parece de suma importância. No entanto, não poderemos, no presente trabalho, abordar de forma senão passageira o problema da terra (que resume também o acesso à moradia, alimentação e perpetuação de tradições culturais - território), pois essa incursão demandaria uma ampliação temática que fugiria ao propósito da presente pesquisa. Nossa pesquisa, como dissemos na introdução, se debruça sobre a questão da emancipação dos povos indígenas para que, no momento em que esses povos acessem os bens materiais para a luta, ao invés de se deixarem levar pelos encantos típicos da indústria cultural (e do gamonalismo, lembrando novamente Mariátegui analisando o contexto peruano), se reconheçam de tal modo indígenas ainda ao ponto de, então, promoverem a luta por reconhecimento cultural e, no curso desse processo, o diálogo intercultural.

Como fica claro, muitas questões deverão ser superadas no curso desse processo de construção de um espaço dialógico que de fato recepcione o que propomos como diálogo intercultural. No entanto, ainda que estejamos começando a tracejar esse percurso, acreditamos que o diálogo intercultural enquanto espaço de equivalência de lógicas discursivas distintas não seja uma proposta descabida ou de pouca relevância.

Sabemos que as propostas de reconhecimento de diferenças culturais não é uma questão nova, e é exatamente isso que nos move a refletir a respeito dos motivos de ainda existirem tantos impasses. Pablo Gonzáles Casanova comenta que na URSS, por exemplo, toda demanda de autodeterminação étnica era tachada de separatista. ${ }^{142}$ No entanto nos chama a atenção o fato de a interculturalidade ser até hoje um tema estudado

142 Op. Cit. Encontrar a convergência da "revolução socialista” e da "revolução nacional" sempre foi difícil. A principal teorização fez-se entorno às classes, enquanto etnias ou nacionalidades atenderam-se como sobredeterminações circunstanciais. Os conceitos de etnias e nacionalidades, assim como os de alianças e frentes oscilaram mais que os de luta de classes, em função de categorias abstratas e de posições táticas. Classe e nação, socialismo e direitos das etnias, enfrentamentos e alianças, defenderam-se separadamente ou juntaram-se segundo os juízos conjunturais do partido sobre as "situações concretas".

$O$ descuido do conceito de colonialismo interno no marxismo oficial e no crítico obedeceu a interesses e preocupações muito difíceis de superar. A hegemonia da União de Repúblicas Socialistas Soviéticas (URSS) nos partidos comunistas do mundo deu às suas colocações sobre o problema um caráter paradigmático. As lutas das nações contra o imperialismo, e a luta de classes no interior de cada nação e em nível mundial, obscureceram as lutas das etnias no interior dos Estados-nação. Somente se encontrou o sentido das lutas nacionais como parte da luta antiimperialista e da luta de classes ou de estratégias variáveis como as "frentes amplas".

Desde os anos trinta e quarenta, toda demanda de autodeterminação na URSS foi tachada de separatista e de nacionalista. A hegemonia da Rússia e dos russos correspondeu a uma constante e crescente liderança. A participação de outros povos nas esferas públicas e sociais chegou a ser praticamente anulada. A própria "classe trabalhadora" que pertenceu ao Partido Comunista da União Soviética (PCUS) era sobretudo russa. 
de maneira isolada de todas as outras questões políticas, econômicas e sociais. Pensamos que o diálogo intercutural, mesmo tendo como pressuposto o reconhecimento das diferenças, não esteja na contramão da construção de um espaço de convivência que até mesmo admita a concepção de um universal, desde que esse universal não se confunda com homogeneizações ou generalizações culturais. A esse respeito, consideramos certeira a posição de Zygmunt Bauman, em sua obra Em busca da política:

\begin{abstract}
Nessa capacidade comum de alcançar uma efetiva comunicação sem recorrer a significados já partilhados e uma interpretação acorde está investida a possibilidade do universalismo. A universalidade não é inimiga da diferença ; ela não requer "homogeneidade cultural" nem precisa de "pureza cultural" e especificamente do tipo de práticas a que se refere esse termo ideológico. A busca da universalidade não envolve o sufocamento da polivalência cultural ou a pressão para alcançar consenso cultural. Universalidade significa nada mais nada menos que a capacidade da espécie se comunicar e alcançar entendimento mútuo - no sentido, repito, de "saber como prosseguir", mas também saber como prosseguir diante de outros que podem têm o direito de - prosseguir por caminhos diferentes. ${ }^{143}$
\end{abstract}

O fundamental é a compreensão de que o universal, diferente do homogêneo e do generalizante, não pressupõe apenas um caminho, mas a totalidade dos caminhos e, nesse sentido, também dos destinos.

\title{
3.3 - A HERMENÊUTICA INTERCULTURAL
}

Iniciaremos este tópico retomando a sugestão de Bauman no sentido de que os intelectuais, no papel de intérpretes, deveriam assumir o papel de especialistas em tradução entre tradições culturais, com vistas à proposta da conversação civilizada. Bauman sugere que em um mundo essencialmente plural, o consenso não deve estar restrito ao papel dos filósofos, que também assumiram na Modernidade esclarecida o papel de legisladores.

Os filósofos (e os intelectuais) deveriam assumir o papel captado pela metáfora do intérprete. Bauman analisa essa proposta com base no argumento de que, sim, os filósofos sempre tiveram a tradição de alcançar consensos e, com esses consensos, segurança para legislar. No entanto, como explica Bauman em Legisladores e intérpretes:

O que é novo não é a autoridade do consenso, mas o fato de que o tipo de consenso que agora parece possuir a autoridade que atribui reputação não é o dos filósofos. O acordo de outras áreas, não filosóficas, também deve se

\footnotetext{
${ }^{143}$ Op. cit. p. 204.
} 
apresentar, e não há como ter certeza de que ele possa ser obtido só pela força do argumento. ${ }^{144}$

Importante ficar claro que Bauman não afasta o filósofo da cena intercultural. Afinal, se essa fosse a proposta, tanto o que o próprio Bauman está sugerindo, como este próprio trabalho, perderia o sentido. A proposta de Bauman caminha no sentido da fixação de um novo campo reflexivo e também um papel distinto para os intelectuais, e isso fica claro na seguinte passagem:

(...) Como o pluralismo é irreversível, um consenso em escala mundial sobre visões de mundo e valores é improvável, e toda Weltanschauungen ("versão de mundo" nossa sugestão de interpretação) ainda existente, baseada com firmeza em suas tradições culturais (de maneira mais correta, nas suas respectivas institucionalizações autônomas de poder), a comunicação entre tradições se torna o maior problema do nosso tempo. Ele já não parece mais temporário, não se pode esperar que seja resolvido "de passagem" por uma espécie de conversação maciça, garantida pela marcha incontida da Razão. (...) Portanto, o problema clama, com urgência, por especialistas em tradução entre tradições culturais. E coloca-os em lugar dos mais centrais entre os peritos que a vida contemporânea possa exigir.

Trocando em miúdos, a especialização proposta se resume à arte da conversação civilizada. (...) A arte da conversação civilizada é algo de que o mundo pluralista necessita com premência. Ele só pode negligenciar essa arte às suas expensas. Conversar ou sucumbir. ${ }^{145}$

Como tivemos a oportunidade de nos manifestar no tópico anterior, não acreditamos que a conquista pela civilidade na conversação será algo tranquilo, pois nos parece improvável que o interlocutor mais forte, no caso do diálogo com os povos indígenas, esteja disposto a abrir mão da reconfortante situação de colonizador em que ele se encontra atualmente. Exatamente por isso analisamos no tópico anterior a necessidade de lutas para a conquista de meios materiais para que, mais do que serem respeitados, os povos indígenas tenham condições de se fazerem respeitar.

No entanto, a proposta da conversação civilizada (para Bauman seria a conversação equitativa) da forma como colocada por Bauman, ou seja, focando no intelectual como um tradutor das tradições culturais, permite que analisemos também o papel dos intérpretes, ou seja, daqueles que atuam no momento hermenêutico dos consensos dialógicos que conferiram sentido ao Direito, quais sejam, o juiz, outros operadores do Direito e também as lideranças (retomando o exemplo utilizado por Roberto Cardoso de Oliveira a respeito de alguns indígenas que dominam os discursos oficiais, por nós trabalhada no capítulo anterior).

\footnotetext{
${ }^{144}$ Op. Cit. p. 156.

${ }^{145}$ Op. Cit. p. 196/197.
} 
Essa aposta na figura desses indivíduos que de fato transitam nas fronteiras ${ }^{146}$ é fundamental para o Direito, pois, no caso dos juízes, diz respeito a indivíduos que, não obstante estarem nas fronteiras, têm no poder a eles conferido um artifício bastante confortável para lavarem as mãos para esse papel e perpetuarem não o diálogo, mas o discurso de suas próprias culturas que, no Brasil e na América Latina, é o discurso do Estado que eles representam e que também os remuneram.

O papel dos intelectuais das fronteiras também é discutido por Dussel, que trabalha a noção do crítico como aquele que vive na "biculturalidade da fronteira". Essa ideia é desenvolvida por Dussel dentro daquilo que ele denomina "projeto transmoderno".

\begin{abstract}
Uma estratégia pressupõe um projeto. Denominamos projeto "trans-moderno" o intento libertador que sintetiza tudo o que temos dito. Em primeiro lugar, indica a afirmação, como autovalorização, dos momentos culturais próprios negados ou simplesmente desprezados que se encontram na exterioridade da Modernidade; que ainda têm sido deixados de fora da consideração destrutiva dessa pretendida cultura moderna universal. Em segundo lugar, esses valores tradicionais ignorados pela Modernidade devem ser o ponto de arranque de uma crítica interna, desde as possibilidades hermenêuticas próprias da mesma cultura. Em terceiro lugar, os críticos, para sê-lo, são aqueles que vivendo a biculturalidade das "fronteiras" podem criar um pensamento crítico. Em quarto lugar, isso supõe um tempo largo de resistência, de amadurecimento, de acumulação de forças. ${ }^{147}$
\end{abstract}

É nessa linha que pretendemos pensar o processo hermenêutico, considerando o papel do intérprete como instrumento fundamental para garantia da simetria do diálogo intercultural. Nos deteremos na figura do juiz, pois pensamos que no estado atual de colonialismo ele pode se abrir para a proposta intercultural e se preocupar em, ainda que de maneira isolada, trazer para o Direito oficial outros sentidos que, ainda

\footnotetext{
${ }^{146}$ Vale conferir também a posição de Dalmo de Abreu Dallari a esse respeito: Tudo isso ganha importância e exige reflexão e aprofundamento quando se verifica a ocorrência de duas inovações importantes na sociedade brasileira contemporânea: $1^{a}$ os índios brasileiros estão sendo forçados a intensificar aceleradamente seu relacionamento com a sociedade circundante, representada especialmente por aventureiros ambiciosos e sem escrúpulos, amparados por ações e omissões dos agentes do Estado; $2^{a}$ embora sejam, institucionalmente e de fato, a parte mais fraca nesse relacionamento, os indios procuram adquirir rapidamente as informações básicas sobre a sociedade agressora, passando a compreender a motivação e as justificativas dos agressores. (...) Desse modo se cria uma dualidade, que muitas vezes afeta pontos essenciais dos interesses indígenas, criando-se, então, a necessidade de um mediador capaz de entender ambas as culturas e de transpor para a linguagem do legalismo formal as peculiaridades dos usos e costumes indígenas que fornecem a base para a sustentação dos direitos reconhecidos pelo Estado. Em tais circunstâncias é decisiva a mediação da perícia antropológica (...). (DALLARI, Dalmo de Abreu. Argumento Antropológico e Linguagem Jurídica. In: SILVA, Orlando Sampaio; LUZ, Lídia; HELM, Cecília Maria Vieira. "A perícia antropológica em processos judiciais." Florianópolis: Ed. da UFSC, 1994. p. 107114.)

${ }^{147}$ Op. cit.
} 
que sejam também oriundos da cultura oficial, garantirão aos povos indígenas o acesso aos tais bens imprescindíveis para a conquista das condições para a simetria discursiva.

Um juiz (e aqui queremos compreender também os Tribunais Superiores e, essencialmente, os Tribunais Constitucionais) que consiga ampliar o campo discursivo do Direito oficial, ainda que esteja, num primeiro momento, promovendo uma situação que no capítulo 2 consideramos como sendo multiculturalismo, sem dúvida alguma estará contribuindo para a construção do espaço intercultural e dialógico que propomos neste trabalho.

Para além dessa situação de transição, o juiz no espaço intercultural (ou nas questões interculturais) será mais um mediador do que uma instituição adjudicante, cabendo aqui a referência feita por Boaventura de Sousa Santos a uma distinção entre o Direito oficial e o Direito de Pasárgada. ${ }^{148}$ Esse papel do juiz num espaço que se pretende intercultural exige do mesmo não uma escolha entre a melhor prática cultural, mas a garantia de que a simetria no discurso não seja tolhida por práticas escusas, enquanto o papel do Estado (e hoje temos as garantias dentro dos Estados Plurinacionais) na função executiva, seria a garantia da titularidade dos meios materiais responsáveis pela simetria no diálogo.

Quando falamos em hermenêutica, uma série de referências teóricas podem ser tomadas, desde a exegese bíblica até a teoria do conhecimento de Hans-Georg Gadamer. O que nos interessa, contudo, é a forma pela qual o Direito ocidental se refere à hermenêutica como técnica de interpretação de seus dispositivos, para a reprodutibilidade técnica do poder e, nesse sentido, qual o papel que o Direito ocidental confere a essa técnica.

A opção por analisar a hermenêutica intercultural no Direito com um recorte bastante preciso e sucinto se explica não só pelo fato de não termos condições de analisar neste trabalho todas as dimensões e correntes filosóficas da hermenêutica, mas principalmente pelo fato de que, para a proposta de proporcionar reflexos da interculturalidade no Direito, a análise crítica da interpretação da lei como técnica de decisão se mostra necessária.

Nesse sentido, a proposta de uma hermenêutica intercultural deve partir da análise da ideia que o Direito oficial do Ocidente e seus teóricos reproduzem

\footnotetext{
148 Op. cit. O direito de Pasárgada assenta no modelo da mediação que, ao contrário do modelo de adjudicação, está expressamente orientado para a contabilização plena dos méritos relativos das posições no litígio e que, por essa via, maximiza o potencial de persuasão do discurso e o consequente potencial de adesão à decisão. (p. 45)
} 
como sendo técnica hermenêutica. Para tanto, a seguir analisamos alguns exemplos de hermenêutica crítica relacionada aos povos indígenas. Por fim, concluimos com a análise da proposta estruturada por Boaventura de Sousa Santos em relação à hermenêutica diatópica.

Os teóricos do Direito ocidental, em sua pretensão de teorizar a reprodutibilidade técnica de sua ciência, explicam que a hermenêutica jurídica pode ser realizada através do método literal (preocupado com o sentido literal dos termos contidos na lei), método lógico sistemático (preocupado com a coerência lógica da norma dentro do sistema/ordenamento jurídico), método histórico (preocupado em buscar o significado que a norma possuía no momento em que foi editada), método comparativo (preocupado em encontrar fundamentos no Direito Comparado para a interpretação) e o método teleológico (preocupado em encontrar os fins sociais a que a lei se destina) ${ }^{149}$. Apesar de termos citado a doutrina de Alexandre F. Câmara, qualquer manual de Introdução ao Estudo do Direito, de Direito Processual Civil, de Direito Civil ou Penal ou qualquer outra especialidade do Direito indicará esses métodos. Importante consignar, inclusive pela crítica que teceremos a seguir, que Alexandre Câmara diz textualmente que esses métodos não devem ser aplicados isoladamente, o que já representa um grande salto técnico.

Apesar da noção já difundida de que os métodos de interpretação do Direito oficial não devem ser aplicados separadamente, a crítica que formulamos na sequência se fundamenta no fato de que, ainda que todos os métodos fossem considerados conjuntamente, não seriam suficientes para atualizar o Direito conforme as mudanças históricas da política, e muito menos se prestar para a garantia da interculturalidade, pois todos eles estão preocupados em dizer o que quer a lei, como se a lei acompanhasse, por si só, os passos da História. Fosse assim, o legislador deveria alterar mensalmente, na PósModernidade, todo o ordenamento jurídico, considerando a obsolescência programada de tudo o que existe em nosso tempo.

O contraponto que pretendemos desenvolver aqui é no sentido de refletir sobre o que Gadamer procurou esboçar a respeito da hermenêutica, ou seja:

Através da interpretação o texto deve vir à fala. Mas nenhum texto e nenhum livro falam se não falarem a língua que alcance o outro. Assim, a interpretação deve encontrar a linguagem correta se quiser fazer com que o texto realmente fale. $\underline{\text { Por }}$ $\underline{\text { isso, não pode haver uma interpretação 'correta em si', justamente porque em cada }}$ um está em questão o próprio texto. A vida histórica da tradição consiste na sua

${ }^{149}$ Cf. CÂMARA, Alexandre de Freitas. Lições de Processo Civil. Vol. I. Ed.17. Rio de Janeiro: Lumen Juris, 2008. 
dependência a apropriações e interpretações sempre novas. Uma interpretação 'correta em si' seria um ideal desprovido de pensamento, que desconhece a essência da tradição. Toda interpretação deve acomodar-se à situação hermenêutica a que pertence. $(\text { grifamos })^{150}$

Como afirmamos, se nos dispuséssemos a analisar a fundo a hermenêutica e a sua relação com a história, a linguagem, a semiologia, a tradição, desviaríamos o foco da presente pesquisa. Assim, o que nos interessa nessa citação de Gadamer é a importância que é conferida ao fato de o texto estar situado no sujeito e a possibilidade de esse texto alcançar, falar com o outro, considerada a pluralidade de resultados hermenêuticos na História. Ou seja, o que nos interessa é a constatação de que a hermenêutica não é um processo matemático ou físico, resultado lógico, previsível e imutável de causa e efeito tecnicamente reproduzível, mas um processo humano, por isso mesmo plural e por vezes contraditório.

Gladston Mamede, em sua obra Semiologia e Direito - tópicos para um debate referenciado pela animalidade e pela cultura, tratou dos aspectos culturais da semiologia e da hermenêutica de forma bastante didática, razão pela qual utilizaremos, com alguma adaptação, essa análise para trabalhar o raciocínio que pretendemos desenvolver.

Gladston Mamede afirma que o Direito é uma mensagem, uma dimensão semiológico-linguística, e o que dissemos sobre o discurso no tópico anterior corrobora com esse entendimento. Analisando o papel dos signos na sociedade, Gladston Mamede inicia o estudo sobre as relações que o pensamento tem com a linguagem, colocando a ideia de que o pensamento é modelado pela linguagem. Neste sentido não haveria pensamento puro, livre das influências da linguagem. Diz o autor também que, além do pensamento, no Direito também a linguagem é necessariamente presente, tendo em vista o fato de o Direito não existir no mundo real, mas no mundo da linguagem. Relativamente à questão da linguagem no Direito, Tércio Sampaio Ferraz Jr. comenta que:

Ao enfoque essencialista da língua opõe-se uma concepção convencionalista, em geral defendida hoje pela chamada filosofia analítica (cf. Ayer, 1978). A língua é vista como um sistema de signos, cuja relação com a realidade é estabelecida arbitrariamente pelos homens. Dado esse arbítrio, o que deve ser levado em conta é o uso (social ou técnico) dos conceitos, que podem variar de comunidade para comunidade. (...) Se nos atermos ao uso, toda e qualquer definição é nominal (e não real), isto é, definir um conceito não é a mesma coisa que descrever uma realidade,

${ }^{150}$ GADAMER, H. G. O Problema da Consciência Histórica. Org. Pirre Fruchon. Trad. Paulo Cesar Duque Estrada. $2^{\circ}$ ed. Rio de Janeiro: Fundação Getúlio Vargas, 2003 p. 54. 
pois a descrição da realidade depende de como definimos o conceito e não o contrário. Ou seja, a descrição da realidade varia conforme os usos conceituais $(\ldots)^{151}$

Essa questão esclarece com bastante precisão o papel que os símbolos culturais têm perante os indivíduos e a influência que sobre eles exercem. É mais do que esperado o fato de o indivíduo tomar como referência a sua própria cultura, ou melhor, a cultura que lhe foi imposta, que lhe foi inserida por meio de instituições como a educação, a família, a religião, o Estado etc. Herskovitz comenta que: Os juízos baseiam-se na experiência, e a experiência é interpretada pelo indivíduo em termos de sua própria endoculturação. ${ }^{152}$

Nessa linha, o sujeito social se submete a uma espécie de adestramento - processo que, mais à frente, faremos referência mais detida quando tratarmos da educação-, pelo qual seus sistemas semiológicos são preenchidos pelo o que a cultura tem para lhe oferecer e cristalizados na prática social.

A universalidade de certas aspirações é inegável, principalmente se tratando de aspirações à vida, à liberdade, à integridade física, à soberania e autodeterminação. No entanto, como comenta Herskovitz, o conteúdo dessas aspirações é diferente, e se dá dentro das culturas:

\footnotetext{
Veremos já como se reconhecem em toda parte certos valores da vida humana, embora não haja duas culturas cujas instituições sejam idênticas na forma. A moralidade é universal, assim como também o prazer estético e algum critério de verdade. As diversas formas adotadas por esses conceitos não passam de produtos da particular experiência histórica das sociedades que os manifestam. Em cada uma, os critérios estão sujeitos a contínuas interrogações e mudanças. Porém, as concepções básicas permanecem para canalizar o pensamento e dirigir a conduta para dar um sentido à vida. ${ }^{153}$
}

Lévi-Strauss afirmou que nossos sistemas de referência se constituem como um conjunto de juízos de valor, centros de interesses etc., estando aí compreendida a visão reflexiva que a educação nos impõe. Retomando Lévi-Strauss: Deslocamo-nos literalmente com esse sistema de referências, e as realidades culturais de fora só são observáveis através das deformações que ele nos impõe, chegando mesmo a colocar-nos na impossibilidade de perceber o que quer que seja. ${ }^{154}$

\footnotetext{
${ }^{151}$ Op. Cit. p. 13.

152 HERSKOVITZ, Melville J. Antropologia Cultural. Tomo I. $8^{\circ}$ ed. São Paulo: Mestre Jou, 1960. p. 86.

153 Op. cit. p. 100.

${ }^{154}$ Op. cit. p. 345.
} 
Nessa linha de raciocínio, a hermenêutica seria, então, a decodificação de símbolos a partir dos elementos culturais de sentido que os constituíram, ou seja, a hermenêutica acaba sendo aplicada como um processo de atualização, de presenteamento histórico e político, de busca do sentido atual do símbolo e, no caso, do Direito, de forma culturalmente reflexiva, pois realizada por um ser humano cultural.

Gladston Mamede atenta para o fato de que a hermenêutica não se limita a encontrar o sentido de um signo delimitado por um contexto, fazendo referência a Gadamer que, em sua obra Verdade e Método, toma como foco o sujeito, destacando, neste, um caráter prejudicioso, no sentido de que: $O$ indivíduo que atualiza um texto, assim, possui uma certa gama de significados prévios (pré-juízos) para a leitura, tendendo a estendê-los sobre a mensagem, moldando-as às suas expectativas. ${ }^{155}$ Essa ideia decorre do fato de que, mesmo frente a normas claras, não se pode afirmar que delas decorreria somente uma única forma particular de compreensão da mensagem, ainda que os juristas acreditem piamente nisso.

A influência que as instituições culturais exercem no sujeito e que este, consequentemente, exerce na hermenêutica, é questão que merece muita atenção. Se o Estado nacional anseia certas formas de comportamento uniforme, todos os sujeitos de cultura, em seus contextos de autonomia e liberdade, devem ter assegurado o direito não só a aderirem, ou não, a essa pretensão uniformizadora, mas também, uma vez optando pela adesão, devem ter o direito a terem reconhecidas suas culturas e a interferência que estas necessariamente exercem no entendimento dos preceitos em jogo no momento dialógico.

Indiscutível, portanto, a prevalência, dentro de um grupo, dos interesses do mais forte se eles realizam, atualizam, interpretam o Direito oficial numa atividade realizada única e exclusivamente dentro dos seus gabinetes, se o acesso a esses gabinetes for do mesmo modo etnocêntrico. O discurso da democracia, da igualdade econômica, da participação política só é efetivado nas circunstâncias em que os detentores de poder julgam viável, ou seja, nas hipóteses em que a concessão desses benefícios não ameace o seu governo (ideia das diferenças aceitáveis de Bauman, analisada no capítulo anterior).

A questão é bastante complexa e intrigante, no entanto, se trata de um estudo voltado para a atuação das forças políticas que sempre estarão presentes nos espaços interculturais e sempre terão reflexos no Direito. Problema importante relativo a

${ }^{155}$ GADAMER, apud, MAMEDE, Gladston. Op. cit. p.112. 
esse sistema semiológico que é o Direito é que, para que se alcance uma comunicação efetiva, os indivíduos deverão observar as regras do sistema semiológico no qual estão inseridos e no qual - e pelo qual - pretendem se comunicar. Essas regras socialmente aceitas são chamadas por Gladston Mamede de "vala semiológica comum”, ou "corredores isotópicos", sendo a cultura o elemento determinante desses corredores.

A noção de "corredores isotópicos" será retomada mais à frente, quando analisarmos a hermenêutica diatópica de Boaventura de Sousa Santos. Por ora, o que interessa para o presente trabalho é pensarmos como essa vala semiológica comum pode ser proporcionada na interculturalidade, considerando a pluralidade de culturas que compõem a humanidade e espaços geopolíticos comuns. Se pensarmos de maneira apressada, poderíamos concluir que, sendo a linguagem um sistema culturalmente situado e compartilhado, o diálogo intercultural não seria possível a partir dessa noção de corredores isotópicos. No entanto, e podemos adiantar, essa conclusão seria equivocada na medida em que desconsideraria os resultados possíveis oriundos da convivência, nos termos psicanalíticos de subjetivação a partir da intersubjetividade, como voltaremos a analisar no tópico reservado à educação.

A convivência, ainda que impotente para empreender uma homogeneização dos fenômenos culturais (que, em verdade, não é do nosso agrado, pois consideramos possível um universal heterogêneo), sem dúvida alguma permitiria o estabelecimento de "valas semiológicas comuns", de "corredores isotópicos", pois a convivência, por não ser uma simples existência ao mesmo tempo, exige o rompimento das cercas, dos muros, pressupondo um compartilhamento de percepções e modos de estar no mundo. Ainda que esses sejam, de início, conflitivos, pois estranhos, em um segundo momento, acreditamos, serão expansivos por permitirem o contato com o outro que, e isso só pode ser alcançado pelo contato sensível, evidenciará muitas características que me são peculiares ou que estavam reprimidas em mim, em termos freudianos.

Dando sequência ao raciocínio que empreendemos neste tópico, julgamos interessante a análise de uma decisão da Corte Interamericana de Direitos Humanos onde existe uma evidência de compreensão do outro sem pretensões de humanizá-lo a partir e pela cultura dos juízes do caso.

A Corte Interamericana de Direitos Humanos deu demonstração admirável de possibilidade de construção de um Estado intercultural através da hermenêutica. No caso nº 12.420 (Comunidad Indígena Xákmok Kásek del pueblo EnxetLengua y sus miembros en contra del Estado de Paraguay), a corte reconheceu o direito de 
proteção judicial através de recursos simples e rápidos, considerando-se a relevância do direito à personalidade jurídica. ${ }^{156}$

Antes de iniciarmos a análise da decisão, importante fazer algumas considerações a respeito do referido direito à personalidade jurídica. Costuma-se discutir à exaustão os direitos civis, políticos, sociais, econômicos e culturais, sem existir uma preocupação efetiva com direitos que estariam em um patamar cronológico anterior, como verdadeiras garantias de gozo e fruição desses direitos. O direito à personalidade jurídica, ao lado de outros direitos, como, por exemplo, o direito de existir em sociedade, assume uma dimensão anterior na medida em que, sem eles, nenhum direito civil, político, social, econômico ou cultural pode ser exercido. No citado caso do mandado de segurança coletivo em que o Superior Tribunal de Justiça do Brasil não reconheceu o cacique como legitimado para a impetração da ação, o direito à personalidade jurídica foi desconsiderado e, consequentemente, os direitos em jogo não puderam ser garantidos ${ }^{157}$.

$$
\mathrm{O} \text { caso } \mathrm{n}^{\mathbf{0}} 12.420 \text { da Corte Interamericana, entre a Comunidade }
$$

Indígena Xákmok Kásek e o Estado do Paraguai, teve como objeto principal a ausência de garantia à propriedade sobre território ancestral. No entanto, a parte da decisão que será analisada no presente estudo, e que servirá de contraponto à decisão proferida pelo Superior Tribunal de Justiça do Brasil, é a parte referente ao direito à personalidade jurídica e à proteção judicial que, segundo entendimento da Corte Interamericana, foram

\footnotetext{
${ }^{156} \mathrm{O}$ termo personalidade jurídica, conceituado pela Corte Interamericana como um parâmetro para se definir se uma pessoa é titular de direito assume, na decisão da Corte, um sentido muito mais amplo do que normalmente a "personalidade jurídica" recebe do Direito Civil, seu berço original. Isso porque o Direito Civil sempre abordou a personalidade jurídica como o atributo que conferiria aptidão para a pessoa fazer uso dos direitos consagrados no ordenamento jurídico e, do mesmo modo, assumir deveres. No Direito Romano, o escravo era considerado coisa, logo não tinha personalidade jurídica. No que diz respeito à pessoa física, a personalidade seria o conjunto de princípios e regras que protegem a pessoa em todos os seus aspectos e manifestações, sendo que, para as empresas, corporações e outras entidades, a personalidade jurídica seria um instrumento, uma técnica jurídica que visa a alcançar determinados fins práticos, como a autonomia patrimonial e a limitação de responsabilidades. Considerando esses conceitos sempre limitados ao rol de tipos de "pessoas jurídicas" existentes, a decisão da Corte Interamericana vai além das definições normalmente fixadas pelo Direito Civil, buscando não no Código Civil, mas na Constituição, no valor do respeito à diferença e, em especial, no princípio da igualdade, a integração do sistema jurídico para estender o direito de ser titular de direitos e deveres também às coletividades não definidas expressamente na legislação dos Estados como "pessoas jurídicas".

${ }^{157}$ Importante considerar que muitos direitos deixam de ser exercidos quando um direito é violado. Deixando evidente a importância dos processos demarcatórios, Tercio Sampaio Ferraz Jr. comenta a respeito da segurança jurídica conferida pela demarcação: (...) Ademais, a demarcação não engendra nenhum direito às terras, pois tal direito é declarado originário (antecede à demarcação). Mas tem sentido de conferir certeza e segurança ao exercício do direito, no que se refere ao seu conteúdo (faculdades) e objeto (terras ocupadas tradicionalmente). (Cf. FERRAZ JR., Tércio Sampaio. A demarcação de terras indígenas e seu fundamento constitucional. In. "Revista Brasileira de Direito Constitucional", n. 3, jan/jun. 2004. p.689-699.) Conferir sobre o tema também tese de doutorado intitulada Direito ao desenvolvimento de comunidades indígenas no Brasil. (ANJOS, Robério N. Tese de Doutorado em Direito - USP. 2009), bem como VILLARES, Luiz Fernando. Direito e povos indígenas. 1. ed. Curitiba: Juruá, 2009.
} 
negados pelo Paraguai no momento em que dificultou o acesso da comunidade aos processos legais para a garantia dos direitos em jogo.

A questão referente ao direito à proteção jurídica é desenvolvida em relação com o direito à personalidade jurídica. Esse direito à personalidade jurídica foi legalmente concedido pelo Paraguai (através do Decreto Presidencial no 25.297, de 4 de novembro de 1987) à comunidade indígena, porém sem os efeitos esperados em relação à proteção jurídica. Além disso, apesar de o Paraguai ter concedido personalidade jurídica à comunidade indígena, foi constatado um alto número de pessoas sem certidão de nascimento e outros documentos necessários para que se fizesse efetivo o direito ao reconhecimento da personalidade jurídica do indivíduo que, como afirmou a Corte, representa um parâmetro para determinar se uma pessoa é titular ou não dos direitos em questão, e se os pode exercer. A violação daquele reconhecimento supõe desconhecer em termos absolutos a possibilidade de ser titular desses direitos e contrair obrigações, e deixa o indivíduo vulnerável frente à não observância dos mesmos por parte do Estado ou de particulares. $^{158}$

O argumento utilizado pela Corte Interamericana para o reconhecimento do direito à personalidade jurídica é amarrado com a garantia constante no artigo 25 da Convenção Interamericana de Direitos Humanos, ${ }^{159}$ ou seja, a garantia de proteção judicial. Nesse sentido, a extensão do direito à personalidade jurídica individualmente compreendido para o direito à personalidade jurídica coletivamente compreendido, poderia garantir, no Brasil, no que diz respeito ao acesso ao Mandado de Segurança Coletivo, a não transfiguração das comunidades indígenas em partido político, em organização sindical, entidade de classe ou associação, fato que claramente impede essas comunidades de, a partir de suas próprias formas culturais de representação, garantirem seus direitos líquidos, certos e sob grave ameaça.

Um entendimento do Estado-Juiz nesse sentido garantiria aos povos indígenas do Brasil, por exemplo, o acesso isonômico ao Poder Judiciário, sem que para tanto os caciques deixassem de ser caciques e assumissem o papel de deputado, de diretor de associação ou de líder sindical (fatos evidentemente impeditivos da ideia de autorealização humana de Honneth). Isso por que a Constituição brasileira, no seu artigo $1^{\circ}$,

${ }^{158}$ WASHINGTON - Corte Interamericana de Direitos Humanos - Caso Xákmok Kásek vs. Estado de Paraguay.

${ }^{159}$ Art. 25 - Toda persona tiene derecho a un recurso sencillo y rápido o a cualquier otro recurso efectivo ante los jueces o tribunales competentes, que la ampare contra actos que violen sus derechos fundamentales reconocidos por la Constitución, la ley o la presente Convención, aun cuando tal violación sea cometida por personas que actúen en ejercicio de sus funciones oficiales. 
inciso IV, erigiu a princípio da República a dignidade da pessoa humana, e não a dignidade da pessoa econômica ou política.

É certo que a natureza econômica e política estão compreendidas na natureza humana, mas também a natureza cultural está, e aqui a noção de integridade psíquica aparece com grande força. Os povos indígenas, justamente por suas especificidades étnicas, assumem outras formas de organização política e social quando comparados com o Ocidente. Como no caso da Comunidade Indígena Xákmok Kásek, a dimensão individual é quase sempre inútil diante da dimensão coletiva. Na sentença proferida pela Corte Interamericana a respeito dessa comunidade consta uma descrição muito interessante pelo fato de captar a essência coletiva da comunidade. ${ }^{160}$

Assim, compreendida a personalidade jurídica como a condição de sujeito para o Direito, uma compreensão restritiva, limitadora, garantiria apenas a proteção jurídica aos sujeitos de um Direito (o oficial), impedindo definitivamente a proteção jurídica aos que antes de serem sujeitos de um direito unilateralmente definido, são também sujeitos de cultura viva.

Outro exemplo interessante de compreensão e respeito pela forma distinta de os indígenas lidarem com o mundo (poderíamos aqui falar em "outras epistemologias") é o julgamento do caso da comunidade Mayagna contra o Estado da Nicarágua. O caso da comunidade Mayagna foi submetido à Corte Interamericana de Direitos Humanos pela Comissão Interamericana em 4 de junho de 1998. Teve como objeto o fato de o governo da Nicarágua não ter demarcado as terras ancestrais da mesma comunidade (que habita o local há mais de 500 anos) e não ter tomado as medidas

\footnotetext{
${ }^{160}$ WASHINGTON - Corte Interamericana de Direitos Humanos - Caso Xákmok Kásek vs. Estado de Paraguay. (...) Los indígenas del Gran Chaco son un grupo heterogéneo de más o menos medio centenar de pueblos cuya aparente unidad surge de la relación asimétrica que todos ellos poseen con la sociedad global. Se trata de una población amerindia estimada en unas doscientas sesenta mil personas que hablan diecisiete diferentes lenguas reconocidas pertenecientes a seis grupos lingüísticos. En la actualidad la situación de los indígenas del Chaco es altamente dinámica. Cuando se hace referencia a pueblos indígenas del Chaco se habla de aquellas unidades territoriales, lingüísticas e históricas que en tiempos anteriores a la desarticulación que resultó de la ocupación efectiva del territorio por el Estado paraguayo estaban constituidas efectivamente como sociedades con una estructura política, control social y organizaciones propias y diferentes de las de cualquier otra sociedad. Es decir, a cada uno de estos pueblos correspondió en la historia una normativa, una jefatura y un sistema de control social independientes y los descendientes de sus integrantes poseen hasta hoy conciencia de una historia exclusiva común. En el seno de cada uno de estos sistemas normativos, los sujetos de derecho eran, más que personas individuales, bandas conceptualizadas como familias. Por ello, las modernas comunidades, que son la expresión sedentarizada de las bandas tradicionales, deberían ser consideradas sujetos de derecho si es un objetivo el respeto de las categorías de los sistemas normativos originales. En el caso particular, se hace referencia al pueblo de los Chanawatsan, o sea a los indígenas que hablaban un dialecto del enxet (lengua), que vivían junto al río Paraguay, frente a la ciudad de Concepción, y que tenían un modo de ocupación tradicional de cazadoresrecolectores. (grifamos e destacamos).
} 
necessárias para a proteção da propriedade das referidas terras e seus recursos naturais. A propriedade das terras se viu ameaçada por ocasião da pretensão por parte do governo da Nicarágua de realizar uma concessão para que a madeireira Sol Del Caribe iniciasse a exploração de madeira na área.

O antropólogo que atuou como perito no caso, Rodolfo Stavenhagen Gruenbaum (primeiro relator da ONU para os povos indígenas), asseverou que os povos indígenas são grupos que mantém uma continuidade histórica com seus antepassados. ${ }^{161}$ Essa ideia embasou a decisão da Corte que reconheceu os seguintes pontos:

147. O artigo 29.b da Convenção estabelece que nenhuma disposição pode ser interpretada no sentido de limitar o gozo e exercício de qualquer direito ou liberdade que esteja assegurado por leis de quaisquer Estados partes ou de acordo com outra convenção em que seja parte um desse Estados.

148. Mediante uma interpretação evolutiva dos instrumentos internacionais de proteção dos direitos humanos, levando em conta as normas de interpretação aplicáveis e, em conformidade com o artigo 29.b da Convenção - que proíbe uma interpretação restritiva de direitos -, esta Corte considera que o artigo 21 da Convenção protege o direito de propriedade em um sentido que compreende, entre outros, os direitos dos membros das comunidades indígenas sobre a propriedade comunal, à qual também está reconhecida na Constituição Política da Nicarágua.

149. Dadas as características do presente caso, é necessário se fazer algumas considerações a respeito do conceito de propriedade para as comunidades indígenas. Entre os indígenas existe uma tradição comunitária sobre uma forma comunal de propriedade coletiva da terra, no sentido de que a posse da terra não pertence ao indivíduo, senão ao grupo e sua comunidade. Os indígenas, em razão de sua própria existência, têm direito de viverem livremente em seu próprio território; a estreita relação que os indígenas mantém com a terra deve ser reconhecida e compreendida como base fundamental de suas culturas, sua vida espiritual, sua integridade e sua sobrevivência econômica. Para as comunidades indígenas a relação com a terra não é meramente uma questão de posse e produção, mas um elemento material e espiritual de que devem gozar plenamente, inclusive para preservar seu legado cultural e transmiti-lo às gerações futuras.

(...)

151. O direito consuetudinário dos povos indígenas deve ser especialmente levado em conta para os efeitos que se pretende. Como produto do costume, a posse da terra deveria bastar para que as comunidades indígenas que careçam de um título

\footnotetext{
${ }^{161}$ WASHINGTON - Corte Interamericana de Direitos Humanos - Caso Comunidade Mayagna vs. Estado da Nicarágua. Los pueblos indígenas se definen como aquellos grupos sociales y humanos, identificados en términos culturales y que mantienen una continuidad histórica con sus antepasados, desde la época anterior a la llegada a este continente de los primeros europeos. Esta continuidad histórica se advierte en las formas de organización, en la cultura propia, en la auto identificación que estos pueblos hacen de sí mismos y en el manejo de un idioma cuyos orígenes son prehispánicos. Estos pueblos se conocen en nuestros países porque mantienen formas de vida y de cultura que los distinguen del resto de la sociedad, y han estado subordinados y marginados tradicionalmente por estructuras económicas, políticas y sociales discriminatorias, que prácticamente los han mantenido en condición de ciudadanía de segunda clase, a pesar de que en las legislaciones, formalmente, los indígenas tienen los mismos derechos que tienen los no indígenas. Pero, en la realidad, esta ciudadanía es como imaginaria, porque siguen sufriendo de formas estructurales de discriminación, de exclusión social, de marginación.
} 
real sobre a propriedade da terra obtenham o reconhecimento oficial dessa propriedade e o consequente registro. ${ }^{162}$

A decisão da Corte Interamericana de Direitos Humanos demonstra uma compreensão das particularidades culturais do outro diferente, e mais do que compreensão, o respeito por essas particularidades e a sua colocação antitética em relação ao Direito ocidental, escrito, positivo. A respeito da insuficiência do Direito escrito, Joaquim José Gomes Canotilho diz do Direito Constitucional: o direito constitucional é um sistema aberto de normas e princípios que, através de processos judiciais, procedimentos legislativos e administrativos, iniciativas dos cidadãos, passa de uma law in book para uma law in action, para uma living constitution. ${ }^{163}$

Um Direito vivo é a proposta que está como antecedente lógico da interculturalidade e, logicamente, de uma hermenêutica intercultural que seja compreendida não como técnica, mas como diálogo formado pela convivência. Boaventura de Sousa Santos propõe a ideia da hermenêutica diatópica, que nos parece bastante pertinente quando tomadas as considerações que tecemos sobre o fato de o contato intercultural ser um contato de estranhamento, de choques.

A ideia de uma hermenêutica diatópica para a realização de um diálogo possível no âmbito intercultural consistiria em compreender uma determinada cultura a partir do topos de outra cultura, sempre partindo do pressuposto de que os topói de uma cultura, por mais fortes que sejam, são tão incompletos quanto a própria cultura a que pertencem, ${ }^{164}$ tendo como premissa para que isso se realize a disposição de aumentar a consciência de incompletude cultural até ao seu máximo possível.

Ora, analisando essa proposta, é inevitável não a considerarmos relativamente problemática, na medida em que o ser humano, principalmente o ocidental, em razão mesmo do seu narcisismo característico, tem dificuldade de se conscientizar de sua incompletude. Ademais, a própria noção de incompletude cultural é complicada, pois a ideia de completude/incompletude sempre se faz através de uma comparação que, como vimos, em matéria de cultura é inviável. No entanto, essa proposta pode se revestir de razoabilidade se esse aumento da consciência de incompletude cultural for compreendida como consciência dos pontos negociáveis da cultura (aberturas culturais)

\footnotetext{
162 Idem. Ibidem.

${ }^{163}$ CANOTILHO, J.J. Gomes. Direito Constitucional. Ed.5. Coimbra: Almedina, 1991. p.175/176.

${ }^{164}$ SANTOS, Boaventura de Sousa. Por uma Concepção Multicultural de Direitos Humanos. Artigo em LADSLAU-BIANCO, Bela \& CAPINHA, Graça (organizadores). Identidades: estudos de cultura e poder. São Paulo: Hucitec, 2000. p. 30.
} 
Apesar da impossibilidade aparente, o diálogo intercultural surge na pós-modernidade como a única via possível para a manutenção das diferenças, e isso pressupõe, no termos de Boaventura de Sousa Santos, a compreensão de que as pessoas e os grupos sociais têm o direito a serem iguais quando a diferença os inferiorizar, e o direito a serem diferentes quando a igualdade os descaracterizar. ${ }^{165}$ Assim, partindo desse pressuposto, bem como considerando as aberturas culturais, a convivência enquanto experiência de contato sensível apresenta-se como forma viável (pois humana, e não técnica e abstrata) para o aumento da consciência dessa abertura e a expansão do ser humano no outro ser humano.

O fato que não devemos deixar de considerar é que para que um juiz pratique uma hermenêutica dessa natureza, ou seja, para que um juiz assuma o papel de mediador de diálogo intercultural, a experiência da convivência com o estranho é prérequisito. Sem essa experiência o juiz não entrará em contato com seus conteúdos reprimidos que, em última instância, são as possibilidades da vida reprimidas pela própria cultura com o desenvolvimento do superego e as experiências de recalque. É no ato de encontrar no outro as possibilidades que minha cultura me negou que percebo a abertura cultural. Assim, a abertura cultural não será uma lacuna encontrada na própria cultura, mas no mundo da vida, plural, onde convivem várias culturas. Nesse sentido, encontrando nesse mundo que está para além de uma única cultura a possibilidade de expansão cultural, torna-se também possível pensar nesse mundo plural a noção dos corredores isotópicos. Mais do que pré-requisito, essa convivência que permite a expansividade pelo diálogo é possível e a hermenêutica intercultural, por isso mesmo, também se mostra como um fato viável, e a Corte Interamericana de Direitos Humanos mostrou isso.

Quando pensamos no processo hermenêutico, portanto, pensamos em um processo que também será dialógico, dentro da proposta de realização, de concretização de um sentido intercultural para o Direito em questão, sem limitações etnocêntricas. O que queremos propor com a ideia de interculturalidade não é um cenário público desprovido de regras, mas um cenário desprovido de legalismo. Nesse sentido, o intérprete não pode abdicar do seu papel de mediador de conflitos discursivos e, por comodismo, se contentar em reproduzir, sob o argumento da legalidade, sua própria lógica discursiva etnocentrada. Para que o juiz, e também os próprios legisladores, agente públicos e lideranças indígenas, assumam sua posição hermenêutica de mediadores de

${ }^{165}$ Idem. Ibdem. 
discursos, a educação para os direitos humanos como prática sensibilizadora para as diferenças e para a resistência é a nossa proposta. 


\section{CAPÍTULO 4 \\ DIÁLOGO INTERCULTURAL E EDUCAÇÃO PARA OS DIREITOS HUMANOS}

O que tomaremos como objetos no presente capítulo são a possibilidade de a educação ser um espaço fértil para o contato intercultural por meio da convivência com o diferente e o que tem sido feito para que isso se torne possível, considerando a explicação de Herskovitz no sentido de que: A educação deve, em seu mais amplo sentido, considerar-se como aquela parte da experiência endoculturativa que, através do processo de aprendizagem, equipa um indivíduo para que ocupe seu lugar como membro adulto de sua sociedade. ${ }^{166}$ Essa concepção de Herskovitz será analisada juntamente com o estudo que Clifford Geertz fez da educação dentro da Psicologia Cultural de Jerome Bruner, que considera a educação não como um processo de preenchimento puro e simples do indivíduo, mas um processo que disponibiliza aos indivíduos as possibilidades culturais de sentido.

A análise da Convenção 169 da Organização Internacional do Trabalho (OIT), da Convenção sobre a Proteção e Promoção da Diversidade das Expressões Culturais (ONU), do Programa Nacional de Educação em Direitos Humanos, do Programa Nacional de Direitos Humanos, o Estatuto do Índio, a Constituição Federal e as alterações realizadas na Lei de Diretrizes e Bases da Educação Nacional permitirá a verificação do que tem sido pensado em termos de interculturalidade e educação indígena. $\mathrm{Na}$ mesma linha, o diagnóstico do que tem sido realmente aplicado e dos preconceitos étnicos das crianças e adolescentes no Brasil fornecerá um contraponto necessário que, podemos adiantar, evidenciará que a ausência da experiência da convivência enquanto contato sensível tem deixado todo arcabouço legislativo no campo da ineficácia.

Quatro focos de abordagem devem ser utilizados para contextualizar a situação jurídica da educação intercultural. O primeiro foco deve se voltar para a análise da educação como forma de assimilação cultural dos povos indígenas. O segundo foco deve abordar a forma pela qual as normas que trataram e tratam da educação indígena consideraram a importância da interculturalidade. O terceiro foco deve analisar em quais

\footnotetext{
${ }^{166}$ Op. cit. p. 101.
} 
normas existe preocupação evidente com a interculturalidade. O quarto foco abordará uma proposta emancipadora de educação para os direitos humanos enquanto campo fértil para a interculturalidade.

A educação como forma de assimilação cultural dos povos indígenas fica evidente no artigo 50 do Estatuto do Índio. Curiosidade que merece relevo é o fato de o Estatuto do Índio, de 1973, ter se utilizado do termo "índio". O “índio", como se sabe, é um elemento da tabela periódica, de número atômico 49, descoberto por Ferdinand Reich e Theodor Richter em 1863. Já ouvimos indígenas dizendo que não existem índios, mas povo Kaiwoa, Xavante, Kariri, Tupinambá etc., o que faz todo sentido. De todo modo, desconsiderando a identificação do outro a partir dos nossos próprios equívocos históricos (o que retomaremos ao final), bem como sua reprodução no Direito oficial, analisemos o teor do artigo 50 do referido Estatuto:

Art.50. A educação do índio será orientada para a integração na comunhão nacional mediante processo de gradativa compreensão dos problemas gerais e valores da sociedade nacional, bem como do aproveitamento das suas aptidões individuais.

Analisemos também o artigo 205 da Constituição Federal:

Art.205. A educação, direito de todos e dever do Estado e da família, será promovida e incentivada com a colaboração da sociedade, visando ao pleno desenvolvimento da pessoa, seu preparo para exercício da cidadania e qualificação para o trabalho.

Ora, se a educação, para a Constituição, deve ser promovida tendo em vista, dentre outros objetivos, qualificar o aluno para o trabalho e o indígena deve ter sua educação orientada para sua integração na comunhão nacional (e aqui já podemos perceber que o contato intercultural começou excluindo o indígena dessa comunhão) com vistas ao aproveitamento de suas aptidões individuais, o resultado técnico da hermenêutica (retomando um detalhe do tópico anterior) que poderia instrumentalizar a aplicação concreta desses dois dispositivos é no sentido de que o indígena deveria ser preparado para o mercado de trabalho. Analisando todos os preconceitos que existem em torno dos povos indígenas, como a ideia de que o "índio vive na rede", "índio é vagabundo", "índio não gosta de trabalho", e todas as outras características constantes da literatura romântica nacional que formam os juízos do nosso povo, vincular a dignidade humana e o direito a 
ter direito dos povos indígenas à necessidade de desempenho de alguma atividade laboral típica do ocidente é um fato inevitável.

Vale fazer referência a uma pesquisa que fizemos juntamente com uma associação indígena de São Paulo ocasião em que pedimos para os "brancos" ocidentais nos fazerem perguntas sobre os povos indígenas, algo que eles quisessem saber sobre os povos originários. Conversando com duas crianças, entre 7 e 10 anos, uma delas nos indagou o motivo pelo qual os índios pintavam o corpo e o motivo pelo qual os índios usavam saias. A outra, por sua vez, nos indagou se os índios iam à escola, e imediatamente foi interrompida pela primeira criança que respondeu: Claro que sim! E minha professora disse que eles têm aula com os humanos!

O que é interessante nessa entrevista é que fica claro que o preconceito é plantado pelos adultos, professores, pais, ao criarem nas crianças os sistemas de referência cultural de maneira preconceituosa. Lévi-Strauss afirmou que nossos sistemas de referência se constituem como um conjunto de juízos de valor, centros de interesses etc., estando aí compreendida a visão reflexiva que a educação nos impõe. Retomamos citação de Lévi-Strauss: Deslocamo-nos literalmente com esse sistema de referências, e as realidades culturais de fora só são observáveis através das deformações que ele nos impõe, chegando mesmo a colocar-nos na impossibilidade de perceber o que quer que seja. ${ }^{167}$

As perguntas que nasceram no próprio íntimo da criança tinham uma carga evidente de curiosidade diante do estranho (por que pintam o corpo, usam saias... outras perguntaram o motivo do nu, enquanto alguns adultos perguntavam se os índios traiam suas mulheres etc.); no entanto, ao dizer que os indígenas tinham aula com os humanos e afirmar que isso foi explicado pela professora, fica claro que a criança assimilou inconscientemente o dado de que o indígena não seria humano! Esse exemplo é apenas uma ilha no meio de um oceano de dificuldades interculturais, mas demonstra que a interculturalidade deve ser construída, preparada na infância, pois é nesse momento que a curiosidade ainda não se transformou em preconceito e o estranhamento não é repelido com tiros, leis ou outras formas de violência e poder, mas com olhares curiosos, por vezes choros, sustos, mas nada muito grave que derrame sangue.

\footnotetext{
${ }^{167}$ Op. cit. p. 345.
} 
O segundo ponto a ser analisado são os dispositivos que tratam da educação indígena para os próprios povos indígenas. A Convenção 169 da OIT dispõe no seu artigo 27:

\begin{abstract}
Artigo 27
1. Os programas e os serviços de educação destinados aos povos interessados deverão ser desenvolvidos e aplicados em cooperação com eles a fim de responder às suas necessidades particulares, e deverão abranger a sua história, seus conhecimentos e técnicas, seus sistemas de valores e todas suas demais aspirações sociais, econômicas e culturais.
\end{abstract}

2. A autoridade competente deverá assegurar a formação de membros destes povos e a sua participação na formulação e execução de programas de educação, com vistas a transferir progressivamente para esses povos a responsabilidade de realização desses programas, quando for adequado.

3. Além disso, os governos deverão reconhecer o direito desses povos de criarem suas próprias instituições e meios de educação, desde que tais instituições satisfaçam as normas mínimas estabelecidas pela autoridade competente em consulta com esses povos. Deverão ser facilitados para eles recursos apropriados para essa finalidade.

No Plano Nacional de Educação em Direitos Humanos ${ }^{168}$, a linha de ação ${ }^{\circ} 14$ da Educação Básica dispõe: Apoiar as políticas públicas dirigidas às escolas de educação indígena, quilombolas e de educação no campo. Ainda, no objetivo estratégico que trata da garantia aos povos indígenas da manutenção e resgate das condições de reprodução, assegurando seus modos de vida, o PNDH III prevê a ação programática de: Promover ações culturais para o fortalecimento da educação escolar dos povos indígenas, estimulando a valorização de suas próprias formas de produção do conhecimento.

Por fim, a Constituição Federal dispõe no seu artigo 210:

Art. 210. Serão fixados conteúdos mínimos para o ensino fundamental, de maneira a assegurar formação básica comum e respeito aos valores culturais e artísticos, nacionais e regionais.

$\S 1^{\circ}$ - O ensino religioso, de matrícula facultativa, constituirá disciplina dos horários normais das escolas públicas de ensino fundamental.

${ }^{168}$ A propósito conferir também texto de Vanessa C. Teixeira, A interculturalidade no Programa Nacional de Direitos Humanos e no Plano Nacional de Educação em Direitos Humanos. Texto apresentado na IX Reunião de Antropologia do Mercosul, 2011, disponível no seguinte sítio eletrônico:

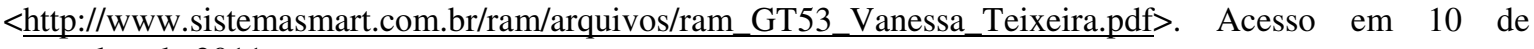
novembro de 2011. 
$\S 2^{\circ}$ - O ensino fundamental regular será ministrado em língua portuguesa, assegurada às comunidades indígenas também a utilização de suas línguas maternas e processos próprios de aprendizagem. (grifamos)

Ainda que o PNEDH seja um documento de natureza de compromisso e o PNDH III um Decreto presidencial que tem a finalidade de orientar as políticas públicas do Governo Federal, sabe-se que a Convenção 169 da OIT vale com estatuto supralegal $^{169}$ no Brasil desde 25 de julho de 2003, considerando que o Congresso a aprovou por meio do Decreto Legislativo n. 143 de 20 de junho de 2002. Também nesse aspecto as escolas indígenas, bilíngues, ainda não receberam a atenção devida, pois a situação de pobreza de muitas comunidades indígenas no Brasil impede o preparo de professores, restando professores ocidentais para ensinar cultura indígena a crianças indígenas. A questão é pensar se isso é suficiente. Carlos Marés comenta:

\begin{abstract}
A educação é um tema de alta importância e gravidade. Embora a Constituição garanta como direito dos povos indígenas a educação bilíngüe, tem sido entendido como uma obrigação aceitar o caráter bicultural. Na realidade, a interpretar o texto pelo princípio da liberdade dos povos viverem como povos, cabe a eles dizer que educação querem ou farão, tendo o Estado brasileiro obrigação de oferecer-lhes ou ministrar-lhes o que pedem e não o contrário, obrigando-os na prática a um aprendizado das coisas e da língua portuguesa.
\end{abstract}

Aliás toda a educação estatal está concebida como um reprodutor monocultural, e
isto acaba por causar problemas não só aos indígenas, mas também aos ciganos, às
comunidades negras e até mesmo às comunidades rurais que recebem uma educação
"universal" urbana. Em relação aos índios há um acréscimo, um plus. A língua, que
a rigor também existe nas outras comunidades. Não raras vezes o
multiculturalismo aplicado se traduz em conteúdo universal expresso em
línguas diferentes, o que é também uma imposicão ou colonialismo cultural,
mais eficiente talvez. $^{170}$ (grifamos)

Assim, não é bastante um professor ocidental ensinar História brasileira em guarani, pois a História em si está em questão. O mesmo se diga em relação à Medicina, ao Direito (oficial e indígena), à Teologia. E mais, também não é bastante ensinar a um indígena a sua história e a um branco a sua história. É necessário entrecruzar essas histórias, de modo que o presente se sinta entrecruzado e o futuro seja planejado como um momento sensível comum. Eis a nossa proposta de pensar um espaço de interculturalidade como um espaço possível para os direitos humanos.

\footnotetext{
169 A definição do estatuto supralegal dos Tratados de direitos Humanos que não foram aprovados com o quórum de Emenda Constitucional nos termos do parágrafo $3^{\circ}$, do artigo $5^{\circ}$, da Constituição Federal foi fixada pelo Supremo Tribunal Federal em 03/12/2008 no julgamento do Recurso Extraordinário n. 349.703/RS. Em julgado mais recente o supremo Tribunal Federal se posicionou no sentido de considerar que em matéria de direitos humanos deveria prevalecer a norma mais favorável à pessoa humana, conforme argumento tecido no Habeas Corpus 96772 de 09/06/2009.

${ }^{170}$ Op. Cit.
} 
O terceiro foco que devemos desenvolver é em relação aos dispositivos legais que realmente falam em interculturalidade, pensando se essas propostas efetivamente possibilitam a interculturalidade. A Lei de Diretrizes e Bases da Educação Nacional recebeu em 2008 a inclusão do artigo 26-A que dispõe:

Art. 26-A. Nos estabelecimentos de ensino fundamental e de ensino médio, públicos e privados, torna-se obrigatório o estudo da história e cultura afro-brasileira e indígena.

$\S 1^{\circ}$ O conteúdo programático a que se refere este artigo incluirá diversos aspectos da história e da cultura que caracterizam a formação da população brasileira, a partir desses dois grupos étnicos, tais como o estudo da história da África e dos africanos, a luta dos negros e dos povos indígenas no Brasil, a cultura negra e indígena brasileira e o negro e o índio na formação da sociedade nacional, resgatando as suas contribuições nas áreas social, econômica e política, pertinentes à história do Brasil.

$\S 2^{\mathrm{o}}$ Os conteúdos referentes à história e cultura afro-brasileira e dos povos indígenas brasileiros serão ministrados no âmbito de todo o currículo escolar, em especial nas áreas de educação artística e de literatura e história brasileiras.

\section{A Convenção 169 da OIT dispõe em seu artigo 31:}

Artigo 31. Deverão ser adotadas medidas de caráter educativo em todos os setores da comunidade nacional, e especialmente naqueles que estejam em contato mais direto com os povos interessados, com o objetivo de se eliminar os preconceitos que poderiam ter com relação a esses povos. Para esse fim, deverão ser realizados esforços para assegurar que os livros de História e demais materiais didáticos ofereçam uma descrição equitativa, exata e instrutiva das sociedades e culturas dos povos interessados.

Vale ainda citar a Convenção sobre a Proteção e Promoção da Diversidade das Expressões Culturais da ONU, que foi internalizada no Brasil pelo Decreto Legislativo n. 485 de 2006 e dispõe eu seu artigo $1^{\circ}$, item $c$ :

Artigo 1 - Objetivos

Os objetivos da presente Convenção são:

(...)

c) encorajar o diálogo entre culturas a fim de assegurar intercâmbios culturais mais amplos e equilibrados no mundo em favor do respeito intercultural e de uma cultura da paz; (grifamos)

Os dois primeiros diplomas legais manifestaram a intenção pelo contato intercultural, mas como meio propuseram os livros de História, fundamentalmente. A Convenção para a Diversidade Cultural da ONU, não obstante ter feito referência 
expressa ao termo "intercultural", também deixou claro somente o fim. Defender a educação em direitos humanos como uma forma de se utilizar o estranhamento como um meio mais humano e menos instrumental para a descoberta do outro e sentir o que nele foi reprimido em mim implica um passo adiante, pois o contato não sensível com o diferente não proporciona a experiência de contato com conteúdos reprimidos, experiência que, como analisado, é expansiva em direção ao outro (e a si mesmo).

E não é somente em um sentido. A troca e a experiência é simultânea, dialógica, e o objetivo estratégico de garantia da participação igualitária e acessível na vida política do PNDH III fixa uma ação programática bastante interessante nesse sentido: Promover junto aos povos indígenas ações de educação e capacitação sobre o sistema político brasileiro. A questão, novamente, é como se fazer isso.

Por fim, o quarto tópico a ser analisado diz respeito à educação para os direitos humanos como processo emancipador. Falar em educação para os direitos humanos é falar sobre um projeto, pois só se pensa, atualmente, em educação para os direitos humanos em termos de uma a garantia dos direitos humanos (e é exatamente isso o que quer significar a ideia de uma educação para). Isso se dá pelo fato de existir um consenso de que a condição humana não vai bem e que somente existe expectativa de melhora através de um processo construtivo de consciência da importância da intersubjetividade enquanto experiência de convívio entre diferentes. É nesse sentido que iniciamos esta reflexão reproduzindo o que Adorno afirma textualmente em um dos textos que servirá de base para este artigo: A exigência que Auschwitz não se repita é a primeira de todas para a educação. ${ }^{171}$

Quando Adorno coloca no centro do debate a exigência de que Auschwitz não se repita e, em outros três textos, ${ }^{172}$ desenvolve a noção de elaboração do passado como uma experiência de contato sensível com esse passado (ao invés do esquecimento) e, ao mesmo tempo, propõe a noção de um projeto educacional contra a barbárie através da emancipação enquanto capacidade de servir-se do entendimento sem a

\footnotetext{
${ }^{171}$ ADORNO, Theodor W. Educação após Auschwitz (palestra na rádio de Hessen transmitida em 18 de abril de 1956). In Educação e Emancipação. Trad. Wolfgang Leo Maar. $6^{\circ}$ reimpressão. Rio de Janeiro: Paz e Terra, 1995. p. 119-138.

${ }^{172}$ O que significa elaborar o passado (palestra ministrada no Conselho para a Colaboração Cristã Judaica em 1959); A educação contra a barbárie (debate na rádio de Hessen transmitido em 14 de abril de 1968); Educação e emancipação (debate na rádio de Hessen transmitido em 13 de agosto de 1969. In Educação e Emancipação. Trad. Wolfgang Leo Maar. $6^{\circ}$ reimpressão. Rio de Janeiro: Paz e Terra, 1995.
} 


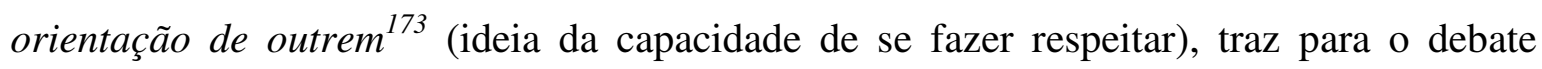
exatamente uma preocupação que atualmente tem sido objeto de reflexão das propostas de uma educação para os direitos humanos.

Quando pensamos em educação para os direitos humanos, precisamos deixar claro que o que se pretende é uma educação que permita que todos os seres humanos, sensíveis da dimensão de sua humanidade, sejam atores da garantia dos direitos humanos de todos os outros seres humanos. Exatamente por isso tomamos a intersubjetividade enquanto experiência de convívio entre diferentes como sendo o objetivo concreto de uma educação que garanta a criação de atores dos direitos humanos, e não apenas "sujeitos de direitos humanos". Esta última é uma concepção simplista que considera "sujeito de direito" como o titular de um direito e um dever ou de um sujeito com titularidade de um poder de exigir o cumprimento de um dever por outro sujeito, deveres esses cujas dimensões são absolutamente mediadas e delimitadas pelas dimensões dos direitos aos quais correspondem. Retomaremos essa questão mais à frente, sendo relevante para este momento inaugural a reflexão acerca da ausência de intersubjetividade real entre seres humanos atualmente, situação flagrada inclusive por Adorno ao analisar a abdicação do próprio "eu" na indústria cultural como forma de se encaixar na cultura. Adorno diz:

\begin{abstract}
Se as pessoas querem viver, nada lhes resta senão se adaptar à situação existente, se conformar; precisam abrir mão daquela subjetividade autônoma a que remete à ideia de democracia; conseguem sobreviver apenas na medida em que abdicam do seu próprio eu. Desvendar as teias do deslumbramento implicaria um doloroso esforço de conhecimento que é travado pela própria situação da vida, com destaque para a indústria cultural intumescida como totalidade. ${ }^{174}$
\end{abstract}

A ideia de intersubjetividade pressupõe, logicamente, a noção de subjetividade, da consciência plena da dimensão, dos desejos e das potencialidades do $e u$. É esse ponto que Adorno resgata ao sugerir a fatalidade da adesão dos seres não emancipados a uma situação imposta de autoridade, que seria diferente da adesão a uma coletividade que, se feita de forma consciente do "eu", poderia ensejar resultados emancipadores, como as lutas por reconhecimento ${ }^{175}$ do movimento estudantil e feminista em maio de 1968 e as lutas dos novos movimentos sociais na América Latina. Nessa linha, nos referimos à menoridade (termo utilizado por Adorno) característica dos seres humanos

\footnotetext{
${ }^{173}$ Cf. Educação e emancipação. Op. Cit.

${ }^{174}$ Cf. O que significa elaborar o passado. Op. Cit.

${ }^{175}$ Aqui fazemos referência à ideia de luta por reconhecimento de Axel Honneth. Cf. HONNETH, Axel. Luta por reconhecimento: a gramática moral dos conflitos sociais. 2.ed. São Paulo: Editora 34.
} 
do nosso tempo, que é muito bem analisada por Alicia Lisondo em termos de uma "cultura do vazio":

A construção da subjetividade exige viver a própria realidade psíquica. Substituir esta realidade pela virtual é cair na deterioração mental e potencializá-la. O pensamento nasce do sentimento. A ilusão surge do universo emocional e é o coração da criatividade. O divórcio entre o sujeito e o coração emocional leva à incessante procura errática pelo "zapping", num deambular sem meta para passar o tempo. ${ }^{176}$

Assim, a abdicação ao "eu" que, segundo Adorno, seria responsável pela adesão aos pressupostos barbarizantes da indústria cultural, se dá (podemos dizer) em razão de um vazio dos sujeitos. Esse vazio pode ser decorrência tanto de uma elaboração do passado em termos de recalcamento, de esquecimento, conforme a proposta de Adorno, como em decorrência de uma ausência de contato intersubjetivo, pois como afirma Alicia Lisondo: A subjetividade se constrói na intersubjetividade. ${ }^{177}$ É bastante esclarecedora a seguinte passagem do texto $O$ que significa elaborar o passado:

Mas a democracia não se estabeleceu ao ponto de constar da experiência das pessoas como se fosse um assunto próprio delas, de modo que elas compreendessem a si mesmas como sendo sujeitos dos processos políticos. Ela é apreendida como sendo um sistema entre outros, como se num cardápio escolhêssemos entre comunismo, democracia, fascismo ou monarquia; ela não é apreendida como identificando-se ao próprio povo, como expressão de sua manifestação. Ela é avaliada conforme o sucesso ou o insucesso, de que participam também os interesses individuais, mas não como sendo a unidade entre os interesses individuais e o interesse geral; $(\ldots)^{178}$

A educação pode ser implementada tanto para contribuir para o vazio, e essa contribuição é muito cara à indústria do consumo (a permanente sensação de vazio é causa da permanente necessidade de preenchimento, e o mundo exterior das prateleiras e vitrines está repleto de "possibilidades"), como pode ser implementada para preencher vazios e estimular o compartilhamento. Esse, no caso de bens não materiais, que integram e constituem os sujeitos, pode ser um compartilhamento de respeito.

Somente quem se conhece tem condições de se preocupar, de doar seu tempo para conhecer o outro. Do contrário, a angústia pelo autoconhecimento transformada pela indústria cultural em ansiedade pelo $\operatorname{Ter}^{179}$ para se preencher impede que os sujeitos vazios se preocupem com algo mais sério, como, por exemplo, a fome do

\footnotetext{
${ }^{176}$ LISONDO, Alicia Beatriz D. Na cultura do vazio, patologias do vazio. Ver. Brasileira de Psicanálise. Vol. 38 (2). P.335-358, 2004.

${ }^{177}$ Op. Cit.

${ }^{178}$ Cf. O que significa elaborar o passado. Op. cit.

${ }^{179}$ A respeito, conferir: FROMM, Erich. Ter ou Ser? Rio de Janeiro: Jorge Zahar Editores, 1977.
} 
outro. Na medida em que a integridade dos sujeitos é garantida pela educação, pela consciência de si e do próprio meio, os olhos que normalmente (leia-se: atualmente, na cultura do consumo) estão voltados para os bens de consumo destinados ao preenchimento do próprio sujeito incompleto, têm condições de mais facilmente encontrar no outro um foco de interesse. Isso porque esse outro passa a ser um detentor de características desconhecidas e, por isso mesmo, potencialmente interessante para a experiência de descobrimento de novas possibilidades reais de Ser; em outros termos, para a expansividade de cada ser humano.

Nesse sentido, o preenchimento do "eu" através da intersubjetividade como uma experiência sensível - pressuposta e simultânea à constituição da subjetividade nos parece um objetivo fundamental a ser considerado como meio, como processo, para uma educação para os direitos humanos com a finalidade emancipatória à qual nos referimos no início deste trabalho. Ou seja, para a constituição de atores de atos de garantia de direitos humanos de outros seres humanos.

Além disso, mostra-se imprescindível a definição do que vêm a ser "direitos humanos". Existem muitas dúvidas sobre o que seriam "direitos humanos". Muitas pessoas já nos indagaram a respeito do que seria "direito humano" e o que seria “direito constitucional”. E vale a reflexão: nem nós, que temos formação jurídica, tivemos desde o início a real dimensão dessa diferença ou paramos para refletir se existiria uma diferença. Fala-se muito em semântica dos direitos humanos e talvez aqui resida realmente a distinção.

Parece-nos que a diferença dos direitos humanos para os outros direitos, que com eles se confundem terminologicamente, reside no impacto discursivo que a noção de "direitos humanos" deve assumir diante de uma violação de direitos relacionados à humanidade que está presente em cada ser humano. Em outros termos, o recurso aos direitos humanos fará sentido quando se perceber que se está diante de uma determinada realidade que exige uma solução conglobante, uma solução impassível de ser construída/justificada pelo recurso a apenas um ou dois direitos específicos.

Exemplificando, para se garantir o direito de propriedade de um latifundiário, o recurso ao direito de propriedade assegurado na Constituição Federal é bastante, na medida em que o latifundiário não precisa, para se defender, de garantia prévia de acesso à Justiça, ou, e no Brasil vale esse exemplo, a garantia prévia do direito de comparecer em juízo alimentado, ou de comparecer em juízo sem prejudicar sua renda familiar pelo desembolso de $\mathrm{R} \$ 6,00$ (seis reais) para ir à Defensoria Pública consultar um 
advogado e voltar para a casa, $\mathrm{R} \$$ 6,00 (seis reais) para voltar à Defensoria Pública para entregar a documentação para a propositura da ação e voltar para a casa, $\mathrm{R} \$ 30,00$ (trinta reais) para obtenção da escritura do imóvel e fotocópia de outros documentos necessários para instruir a petição inicial e mais $\mathrm{R} \$ 6,00^{180}$ (seis reais) para ir ao fórum para a audiência e voltar para a casa de ônibus.

Já para o trabalhador que vive com meio salário mínimo, ou seja, cerca de $\mathrm{R} \$ 300,00$, os gastos mínimos para ter acesso a um advogado público e ao Poder Judiciário representam $15 \%$ de seus rendimentos (considerada a situação hipotética descrita no parágrafo anterior). Nesse caso, não é o bastante garantir a esse trabalhador o direito de propriedade inscrito na Constituição Federal, pura e simplesmente, para conferir a ele o direito de permanecer em sua residência em um caso hipotético em que o Poder Público, por "interesse público", queira despejá-lo para a construção de rodovias (ou para maculados fins de limpeza social urbana).

A garantia do próprio direito de propriedade desse trabalhador representa, de forma reciprocamente implicada, a garantia de ter uma residência fixa que, como se sabe, é requisito para que ele tenha um vínculo empregatício, uma conta no banco onde possa receber ou guardar seus rendimentos, bem como para manter seus filhos matriculados em uma escola pública (endereço fixo é pré-requisito).

Exatamente diante dessa necessidade de se garantir um conjunto de direitos paralelamente ao direito violado imediatamente (propriedade, no nosso caso hipotético), e pelo fato de que a garantia desse direito representa a garantia de tantos outros, é que as construções reflexivas sobre os direitos humanos têm colocado esses direitos numa posição semântica que induz o reconhecimento de sua natureza interdependente e complementar.

Assim, quando falamos em direito de propriedade podemos, ou não, estar falando em direitos humanos. Não estaremos falando em direitos humanos (ou não precisaremos recorrer a essa semântica) se esse direito for pertencente a um titular que,

\footnotetext{
${ }^{180} \mathrm{R} \$ 48,00$ (quarenta e oito reais), que é a soma bastante rasa dos valores despendidos por um usuário da Defensoria Pública para acessar a Justiça na cidade de Sâo Paulo, equivale, hoje, a $5 \mathrm{Kg}$ de arroz, $2 \mathrm{Kg}$ de feijão, $2 \mathrm{Kg}$ de farinha de mandioca, $2 \mathrm{Kg}$ de farinha de trigo, e 3 dúzias de ovos.

Segundo dados do IBGE: $O$ número de famílias com rendimento familiar per capita de até 1/2 salário mínimo caiu de 32,4\% para 22,6\%, em dez anos. No entanto, em 2008, metade das famílias brasileiras ainda vivia com menos de R\$415 per capita. Mais da metade das mulheres sem cônjuge e com todos os filhos menores de 16 anos viviam com menos de $R \$ 249,00$ per capita. Conferir essa informação no seguinte sítio eletrônico <http://www.ibge.gov.br/home/presidencia/noticias/noticia_visualiza.php?id_noticia=1476\&id_pagina=1> Acesso em 19 de maio de 2011.
} 
violado em seu direito de propriedade, tem condições de defendê-lo sem a necessidade de exigir a realização de outros direitos. Para esse cidadão, o direito de propriedade em si basta, pois a semântica racional instrumental também basta. Por outro lado, estaremos falando de direitos humanos (ou precisaremos dessa semântica) se o direito violado for dependente e ao mesmo tempo pré-requisito de outros direitos e para outros direitos relacionados à dignidade humana. E que fique claro que não estamos dizendo que o latifundiário não precisa do direito à moradia. $\mathrm{O}$ que dizemos é que ele já tem esse direito concretizado e o trabalhador do nosso exemplo não.

Portanto, nem a ideia hipócrita e cínica de que todo direito é humano por estar direta ou indiretamente ligado ao ser humano (ideia essa que está na base da frase “direitos humanos para humanos direitos"), nem a ideia confusa de que direitos humanos se confundem com direitos constitucionais devem se traduzir como ideias aptas a acinzentar nossos horizontes. Quando falamos em direitos humanos, falamos em um fundamento, em uma semântica, que exige o "chamamento ao processo" de outros direitos diretamente dependentes e complementares do direito violado.

A grande questão reside no fato de que o momento ou os casos em que essa semântica é exigida não é passível de positivação, depende de caso a caso e somente um ser humano (emancipado) pode ser capaz de aferir essa exigência. Eis o motivo da educação para os direitos humanos. A educação para os direitos humanos é a educação para a sensibilização do ser humano para que ele esteja apto a flagrar as ocasiões em que os direitos humanos devem ser trazidos à realidade como semântica de Justiça e quando o Direito racionalmente considerado é bastante para isso. É a educação para a percepção das situações em que um ser humano precisa mais do que está perdendo para ter de volta simplesmente, e exatamente, o que perdeu. Mas para isso é necessário o desenvolvimento da sensibilidade para as necessidades e peculiaridades de cada ser humano. No termos de Adorno, é preciso delicadeza:

\footnotetext{
Acredito ser importante para a educação que se supere este tabu acerca da diferenciação, da intelectualização, da espiritualidade, que vigora em nome do menino saudável e da menina espontânea, de modo que consigamos diferenciar e tornar tão delicadas as pessoas no processo educacional que elas sintam aquela vergonha acerca de cuja importância havíamos concordado. ${ }^{181}$ (grifamos)
}

\footnotetext{
${ }^{181}$ Cf. A educação contra a barbárie. OP. Cit. A vergonha a que se refere Adorno é a vergonha da rudeza da cultura: (...) é preciso haver clareza de que até hoje ainda não despertou nas pessoas a vergonha acerca da rudeza existente no princípio da cultura. E que somente quando formos exitosos no despertar desta vergonha, de maneira que qualquer pessoa se torne capaz de tolerar brutalidades dos outros, só então será possivel falar do resto.
} 
$\mathrm{Na}$ tentativa de tocar de forma mais sensível a questão, gostaríamos de pensar a educação para os direitos humanos a partir de uma experiência que muito nos chamou a atenção em uma visita a uma ocupação urbana na zona leste de São Paulo na primeira metade de 2011. Estávamos em uma visita a uma comunidade indígena que estava vivendo nessa ocupação, e o indígena que nos conduzia vestia uma camiseta com a seguinte frase: Eu sou o contra-indicação: o favelado com um livro na mão.

Esse indígena que nos acompanhava habita uma região pobre da cidade de São Paulo e cursa Ciências Sociais em uma Universidade Pública. A questão que nos intriga é que, considerando a frase inscrita na camiseta do nosso guia, todo o estudo das teorias e correntes das Ciências Sociais, todo o dever ser da ciência formal estava em absoluta oposição à realidade experimentada por ele e, considerando esse fato, fazia todo sentido a frase ao propor que o sujeito que tem um livro na mão e é favelado é, por consequência, "contraindicado" para reproduzir a teoria.

Explicamos.

A ideia da contraindicação nos chamou a atenção para a síntese dialética que o nosso próprio guia representava enquanto "favelado" com acesso aos livros. Isso por que os livros não apenas fornecem informações preciosas para o domínio de bens culturais, mas também por que contém uma descrição da realidade normalmente falha e enviesada, descrevendo o que deveria ser como o que é e, desse modo, plasmando a consciência da realidade nos seus leitores que não vivem uma experiência de vida oposta à teoria. No entanto, o resultado desse contato entre estudante e teoria, no caso do indígena "favelado", gera uma síntese crítica absolutamente emancipadora, pois a contraindicação dessa síntese reside exatamente no fato de que os eufemismos de realidade constantes nas teorias dos livros didáticos são imediatamente percebidos, sentidos, por aquele ser humano síntese que, exatamente por ser anulado da realidade eufemisada, não se conforma e denuncia a mentira e suas intenções que existem naquelas teorias que formam crianças, jovens e adultos. Aquele indígena é a figura do ser humano síntese, do filósofo das fronteiras, aquele que vive na biculturalidade das fronteiras e que tem condições de mediar diálogos.

A dialética entre teoria e realidade, nesse caso, não simplesmente é responsável por descortinar as promessas e a falsa política dos livros didáticos, mas por causar no próprio "favelado" que estuda numa Universidade pública uma experiência sintética de consciência que, se fosse experimentada por um indivíduo que nunca tivesse 
experimentado a sensação de "estar na fronteira das realidades", não seria uma experiência sintética de consciência situacional do presente, mas uma simples confirmação nada empírica de possibilidades criadas em gabinetes de outros indivíduos isolados e transformadas em teoria, ou seja, em verdades absolutas. Exemplo desse perigo é a forma pela qual é contada a história do descobrimento das Américas e do Brasil e a cultura dos povos indígenas. Nesse caso, os descobridores são super-heróis e os indígenas, que eram selvagens, hoje viraram folclore.

A ideia de contraindicação do favelado com o livro na mão deveria estar por trás dos projetos de uma educação para os direitos humanos enquanto uma educação que, nos termos propostos por Adorno, permitisse a coragem de se servir do entendimento sem a orientação de outrem e contra o poder que define verdades cegando os sujeitos. Ou seja, uma educação que permitisse flagrar nas várias expressões de educação (família, mídia, religião, escola) a presença das falácias e das mensagens subliminares da indústria cultural. Adorno afirma, a esse respeito:

Finalmente, o centro de toda educação política deveria ser que Auschwitz não se repita. Isto só será possível na medida em que ela se ocupe da mais importante das questões sem receio de contrariar quaisquer potências. Para isto teria de se transformar em sociologia, informando acerca do jogo de forças localizado por trás da superfície das formas políticas. ${ }^{182}$

Essa consciência da presença do poder que instaura a barbárie é essencial para o desenvolvimento daquela sensibilidade que propusemos como pressuposto para a percepção da necessidade dos direitos humanos em casos reais. Isso, contudo, somente é possível se pensarmos em uma educação que proporcione a experiência antitética com a realidade sensível. Adorno é bastante enfático acerca da necessidade de contato com a realidade, especificamente com a realidade do horror:

Certa feita uma experiência me assustou muito: numa viagem ao lago de Constância, eu lia num jornal de Baden em que se informava acerca da peça Mortos sem sepuItura, de Sartre, que representa as situações mais terríveis. A peça incomodava visivelmente o critico. Mas ele não explicou este incômodo mediante o horror da coisa que constitui o horror de nosso mundo, mas torceu a questão como se, frente a uma posição como a de Sartre, que se ocupara do problema, nós tivéssemos, por assim dizer, um sentido para algo mais nobre: que não poderíamos reconhecer a ausência de sentido do horror. Resumindo: o critico procurava se subtrair ao confronto com o horror graças a um sofisticado palavrório existencial. O perigo de que tudo aconteça de novo está em que não se admite o contato com a questão, rejeitando até mesmo quem apenas a menciona, como se, ao fazê-lo sem rodeios, este se tornasse o responsável, e não os verdadeiros culpados. ${ }^{183}$

\footnotetext{
${ }^{182}$ Cf. Educação após Auschwitz. Op. Cit.

${ }^{183}$ Cf. Educação após Auschwitz. Op. Cit.
} 
Em termos bem simples, somente quem passa pela experiência de não se "desumanizar" por não consumir nenhum tipo de produto do McDonald's, da Nike ou da Coca-Cola, se sentirá seguro para não consumir esses produtos nunca mais - ou só às vezes; e essa experiência coletivizada poderia ter impactos absolutamente relevantes na definição do curso da história do capitalismo, nos termos que propusemos no estudo dos obstáculos para o diálogo intercultural simétrico.

A educação que se faz sobre temas fundamentais deve se preocupar com a transformação dos seres humanos em seres delicados e sensíveis, de modo que a rudeza, quando manifestada por razões psíquicas as mais diversas (e é importante ficar registrado que não consideramos a possibilidade de um mundo perfeito, edênico), possa ser percebida pelo superego do maior número de pessoas possível ao ponto de criar nessa pessoa a vergonha pela brutalidade e, em última instância, evitar que a brutalidade se concretize (pois também consideramos que o álibi do arrependimento é pouco satisfatório para um mundo do modo que pretendemos).

Assim, ao invés de se ensinar sobre "os índios brasileiros" na escola, deveríamos caminhar no sentido de ensinar sobre o cacique Veron e, assim, expor com cheiro e cor de sangue, a situação dos guarani-caiová no Mato Grosso do Sul. Ao invés de ensinar sobre o MST (Movimento dos Sem Terra) com imagens de pessoas com foices na mão ao ar ou de pessoas destruindo laranjais, que também existisse espaço para apresentar aos educandos a história de José Claudio Ribeiro da Silva e de Maria do Espírito Santo da Silva, expondo com situação sensível, ou mais sensível, a situação do agroambientalismo brasileiro.

Importante considerar também que essa educação merece maior atenção no ensino infantil. Adorno considera essa questão na seguinte passagem:

\footnotetext{
Quando falo de educação após Auschwitz, refiro-me a duas questões: primeiro, à educação infantil, sobretudo na primeira infância; e, além disso, ao esclarecimento geral, que produz um clima intelectual, cultural e social que não permite tal repetição; portanto, um clima em que os motivos que conduziram ao horror tornemse de algum modo conscientes. ${ }^{184}$
}

Assim, parece-nos que o foco central seja na educação das crianças, enquanto constituição de novos atores políticos, que a educação para os direitos humanos nos termos propostos acima deve se concretizar. Contudo, e também por meio dos mesmos

\footnotetext{
${ }^{184}$ Cf. Educação após Auschwitz. Op. Cit.
} 
métodos, ou seja, pelo contato sensível com a realidade antitética às teses dos livros didáticos (de vestibular, de Medicina, de Direito, de Engenharia, de Ciências Sociais, de Filosofia etc.), consideramos relevantíssima a educação para os direitos humanos também para os adultos, especialmente no ensino superior, quando de forma mais acentuada o ser humano é apartado de sua integralidade e redefinido em termos de seu papel social. E aqui recuperamos um dos grandes problemas do Direito enquanto campo aberto para a realização dos direitos humanos, ou seja, a limitação sujeito de direito e suas relações aos seus papeis sociais.

Quando estudamos em Teoria Geral do Direito quem é o sujeito jurídico, o sujeito de direito e as relações jurídicas, lemos em Kelsen que ele não deveria ser considerado. ${ }^{185}$ Com mais sensibilidade Tércio Sampaio afirma:

\begin{abstract}
As duas concepções de sociedade têm consciências diferentes para a noção de relação jurídica. Se a sociedade é concebida como conjunto de seres humanos concretos, relações jurídicas serão relações entre indivíduos. Se é concebida como sistema de ações, serão relações entre os papéis sociais a elas correspondentes. No que segue, adotamos a segunda opção. Assim, por exemplo, compra e venda são ações do papel de vendedor e comprador cuja relação é regulada juridicamente. ${ }^{186}$
\end{abstract}

Realmente a regulamentação de relações sociais entre "papéis sociais" é muito mais funcional para a criação de normas jurídicas e para a compreensão dogmática. No entanto, é bastante curioso o fato de se abandonar o indivíduo enquanto ser humano concreto com tanta facilidade. Ainda que a maior parte das relações sociais se dê através dos papéis assumidos pelos seres humanos, a partir do momento em que falamos em "dignidade humana" chamamos para o Direito, por consequência, um ser humano concreto. Garantir a dignidade de Fulano pelo fato de ser ele trabalhador ou consumidor é reduzir a sua dimensão humana, e isso precisa ficar claro, sentido. As famílias das vítimas da ditadura não devem ser indenizadas pela perda de um mártir, de um filho ou de um pai ou de uma mãe, mas pela perda do Mário, do João, da Maria, etc., pois a relação entre o Estado ditatorial e os militantes, além da relação institucional, gerou dor, lágrima, grito e, por mais que se argumente em sentido contrário, isso não é abstração social, mas sentimento humano concreto.

As abstrações em papéis sociais nos poupam do contato com o ser humano que tem cheiro, calor, gosto. Ainda que esse gosto seja amargo, como efetivamente o é em nossas bocas quando os nossos hormônios fazem folia em nossas

\footnotetext{
${ }^{185}$ Cf. HANS, Kelsen. Teoria Pura do Direito. São Paulo: Martins Fontes, 2009.

${ }^{186}$ Op. Cit. P.137.
} 
veias. Garantir a dignidade humana através do papel social do indivíduo é retirar essa dignidade da sua condição de fim e assegurá-la apenas enquanto meio, pois, neste caso, somente através de um meio redutor (o seu papel social) essa dignidade será sentida pelo ser humano completo (e, aí sim, concreto).

A redução do ser humano a uma entidade abstrata ou a um papel social pode ser bem compreendida quando estudamos Teoria do Direito, e exatamente por isso não fazemos uma crítica a essas concepções citadas. $\mathrm{O}$ que queremos colocar em questão é a incapacidade de se formar operadores do Direito que tenham a sensibilidade para compreender que tudo isso é muito redutor no momento de realização do Direito. E quando estamos diante de culturas diversas, então, tudo se duplica em barbárie, pois os papéis são outros, com outros sentidos. A esse respeito, Eduardo Bittar resume a questão de forma bastante precisa:

(...) A rica experiência humana, se subaproveitada, é desperdiçada, quando o olhar se centra num único canal de expressão, o que na sociedade logocêntrica significa uma supervalorização do discurso verbal, ou quando o olhar despreza as perspectivas culturais por meio das quais se percebe a capacidade criativa, inventiva, humana. ${ }^{187}$

Retomando o primeiro foco da nossa análise, qual seja, a pretensão assimilacionista da educação para os povos indígenas, anotamos que a própria lei brasileira se vale do termo "índio" de maneira genérica. Vivian Urquidi comenta que o termo "índio" é uma categoria colonial, e escreve:

Por esse motivo, enquanto etnia é uma categoria que descreve e especifica um grupo
determinado - aimará, sioux, terena, por exemplo -, com certas características sócio-
culturais comuns, índio é uma categoria supraétnica, i.e. uma categoria relacional.
Além disso, índio é uma generalização que si inicia desde o primeiro contato do
colonizador com os povos conquistados, e que unifica e simplifica a diversidade dos
povos indígenas. Escamoteia, finalmente, a posição de subordinação em relação ao
outro que é dominante e etnicamente diferente.

Quando Vivian Urquidi diz que "índio" é uma generalização que unifica e simplifica a diversidade dos povos indígenas, chama atenção para a ausência de sensibilidade nas próprias generalizações. Em matéria de direitos humanos e na linha de uma educação voltada para a proposta de que Auschwitz não se repita, a desconstrução das

${ }^{187}$ BITTAR, Eduardo C. B. Democracia, Justiça e Direitos Humano: estudos de teoria crítica e filosofia do Direito. São Paulo: Saraiva, 2011. P. 219.

${ }^{188}$ Op. Cit. 
generalizações é fundamental, e uma educação emancipadora no sentido dessa desconstrução deve ser uma via de mão dupla, emancipando não apenas os opressores (e os opressores em potencial), mas também os próprios oprimidos - nos termos da ideia de terem condições de se fazerem respeitar.

A desconstrução das generalizações não poderá pressupor do contato sensível entre os particulares e, para que esse contato seja efetivo, ambas as partes deverão estar preparadas para sofrer os impactos do estranhamento diante do outro estranho e, ainda assim, reagir com respeito e equilíbrio. Nesse particular, pensamos que lei alguma poderia permitir, exigir ou proibir qualquer reação por parte desses seres humanos em contato, pois estamos tratando de um contato que ocasionará reações psíquicas, instintivas, passíveis de orientação não por leis (abstratas, distantes, gerais, que impõem molduras), mas por práticas pedagógicas que não prescindam do contato sensível com a realidade, que permita os sustos, o toque, os risos, enfim, que permita o desencadeamento da sensibilidade ao fato de o mundo real não se remir ao "eu", mas ser algo muito maior e mais vivo, ou seja, "eu mais o outro".

Neste ponto nos parece fundamental uma nota bastante séria a respeito da noção de sensibilidade como algo a ser promovido pelas práticas pedagógicas para os direitos humanos. Por vezes incorremos em uma confusão inadmissível, vendo na sensibilidade uma característica das pessoas inertes, susceptíveis, frágeis. Esse equívoco não pode ocorrer, pois uma educação para os direitos humanos deve ser uma educação para a emancipação, e não há emancipação na passividade. A emancipação pela sensibilidade, e não pela fragilidade, faz com que o ser humano orientado pelo porteiro a não atravessar a porta da lei (parafraseando Kafka) ${ }^{189}$ não se conforme e, ciente do que faz, arrombe a porta, faça a invasão e promova a pilhagem de sua dignidade. O ser humano frágil, inerte, é aquele que, ao invés de arrombar a porta ou invadir, envelhece e morre aguardando ordens e autorizações que nunca virão.

\footnotetext{
${ }^{189}$ O conto Diante da lei está na obra $O$ processo, de Franz Kafka, e aborda a história de um camponês que pretende entrar na lei e, ao indagar ao porteiro sobre essa possibilidade, recebe como resposta: É possível. Mas agora não. A porta da lei permanecia aberta e durante anos o camponês aguardou, algumas vezes tentava ver para além da porta e ouvia do porteiro: Se o atrai tanto, tente entrar apesar da minha proibição. Mas veja bem: eu sou poderoso. E sou apenas o último dos porteiros. De sala para sala porém existem porteiros cada um mais poderoso que o outro. Nem mesmo eu posso suportar a simples visão do terceiro. Os anos se passaram e o camponês envelheceu. Com dificuldade, já cego e próximo da morte, o camponês faz ainda uma última pergunta ao porteiro: Todos aspiram à lei. Como se explica que em tantos anos ninguém além de mim pediu para entrar? E o porteiro, que nunca lhe havia dito ser proibida a entrada, conclui: Aqui ninguém mais podia ser admitido, pois esta entrada estava destinada só a você. Agora eu vou embora e fecho-a.
} 
O ser humano sensível, portanto, tem sua sensibilidade aguçada para perceber o outro, nas suas mais sutis peculiaridades, como Brecht percebeu no fragmento poético que citamos na introdução. O ser humano frágil, por sua vez, tem sua sensibilidade aguçada para o lamento eterno e a inércia permanente diante da derrota que o ameaça. $\mathrm{O}$ ser humano sensível exige e luta pelo reconhecimento e respeito. O ser humano frágil, quieto e ensimesmado, aceita ser só tolerado.

Qualquer criança é, em potencial, opressor e oprimido. Será opressor se submetido a experiências de embrutecimento e preconceito. Será oprimido se submetido a experiências de violência e silêncio. Nem uma e nem outra hipótese retratam uma condição emancipada, pois tanto o opressor quanto o oprimido estão, dentro de uma proposta de educação emancipadora, no mesmo polo, qual seja, no polo dos destituídos de sensibilidade.

Essa noção da criança como opressor ou oprimido em potencial nos parece muito pertinente, pois coloca a educação em uma posição ativa. A educação não é um duto ou veículo da cultura, como se a criança fosse um recipiente vazio e inerte em que seriam despejados os costumes e as engrenagens de adaptação social. A criança é um ser em ação, em busca, e as escolhas que fará dependerão dos bens culturais que estiverem ao seu alcance.

Sem a pretensão de esgotar o assunto, nos parece de muita valia a análise de Cliffor Geertz sobre os estudos de Jerome Bruner sobre a educação na Psicologia Cultural. Nesse sentido, Geertz comenta:

O desdobramento dos aspectos críticos do pensamento humano, a atenção,
juntamente com os outros, para com os objetos e ações, a atribuição de crenças,
desejos e emoções a terceiros, a apreensão da importância geral das situações, o
sentimento de individualidade - aquilo que Bruner chama de "entrada no sentido"-,
tudo isso começa muito cedo no processo de desenvolvimento, antes não apenas da
escolarização formal, mas antes da marcha e da aquisição da linguagem. "Os bebês,
como se constatou, eram muito mais inteligentes, mais dotados de iniciativa do que
reativos em termos de cognição, e mais atentos ao mundo social imediato a seu redor
do que se suspeitara anteriormente. Decididamente, não habitavam num mundo de
'confusão alvoroçada e e florescente': pareciam estar a procura de estabilidade
preditiva desde o início. ${ }^{\text {. }}$ "

Os estudos de Bruner caminham no sentido de demonstrar que a ideia de que falta algo à criança é menos apropriada do que a ideia de que a criança está a

${ }^{190}$ Op. Cit. p. 169. 
procura de algo e constrói seus referenciais culturais com o material e os referenciais que lhe estão imediatamente ao alcance.

Considerar até o bebê e a criança pré-escolar como agentes ativos, determinados a dominar uma forma particular de vida, a desenvolver um modo operacional de ser/estar no mundo, exige que se repense todo o processo educacional. Trata-se menos de dar à criança algo que lhe falta do que de facilitar algo que ela já tem: o desejo de dar sentido ao self e aos outros, o impulso de compreender que diabo está acontecendo.

Para Bruner, o fator facilitador crucial, aquilo que concentra a mente, é a cultura "o modo de viver e pensar que construímos, negociamos, institucionalizamos e, por fim (depois de tudo acertado), acabamos chamando de 'realidade', para nos consolarmos. Qualquer teoria da educação que tenha a esperança de roformá-la (e praticamente não existe nenhum outro tipo) precisa treinar sua atenção na produção social do sentido. Os termos em que a sociedade e a criança - a "realidade" já presente e o intelecto ágil que é fisicamente atirado nela - implicam uma à outra são elaborados, em boa parte, na sala de aula, ou pelo menos o são em nossa sociedade voltada para escola. É lá que a mentalidade é mais deliberadamente moldada, que a subjetividade é mais sistematicamente produzida e que a intersubjetividade - a capacidade de "ler outras mentes" - é mais cuidadosamente cultivada. 191 (destacamos)

A ideia da educação de Bruner que de fato interessa para a interculturalidade não é a educação em sala de aula, pois no caso dos povos indígenas o modelo educacional não compreende a sala de aula. O que interessa, e onde realmente está o foco de preocupação de Bruner (e de Geertz), é a educação como instrumento que participa dos processos de atribuição de sentido aos outros e de cultivo da intersubjetividade como capacidade de ler outras mentes. A educação, como comenta Geertz ainda em referência a Bruner, é um espaço de narrativas (no mais extenso plural):

Crescer entre narrativas - as próprias, a dos professores, colegas, pais, zeladores e vários outros tipos daquilo que Saul Bellow chamou, certa vez, sarcasticamente, de "professores da realidade" - é o palco essencial da educação: "vivemos num mar de histórias". Aprender a nadar nesse mar, a construir histórias, entender histórias, classificar histórias, verificar histórias, perceber o verdadeiro sentido das histórias e usar as histórias para descobrir como funcionam as coisas e o que elas são, é nisso que consiste, no fundo, a escola, e além dela, toda a "cultura da educação". ${ }^{192}$

No nosso modo de enxergar a questão, a educação é um tópico imprescindível para a interculturalidade e, em especial, para o diálogo intercultural. Práticas pedagógicas que não se preocupam com a disponibilização de múltiplas narrativas,

\footnotetext{
${ }^{191}$ Op. Cit. p. 170.

192 Op. Cit. p. 171.
} 
fecham o cenário de possibilidades tanto de sentido ao self como de sentido aos outros e, assim, anula desde o início a fundamental capacidade de ler outras mentes.

Num mundo de tantas incertezas e buscas incessantes por caminhos quase sempre equivocados, também podemos olhar para a educação como um espaço de escolhas emancipatórias também para adultos, pois também estes, hoje, se encontram em um processo de eterna busca de sentido ao self e aos outros.

No campo do Direito, essas considerações são fundamentais. Boaventura de Sousa Santos ao descrever a estrutura do ensino atualmente, lança luz sobre essa preocupação, chamando atenção para o fato de o ensino jurídico não ser um processo de aberturas para múltiplas narrativas, mas para apenas uma narrativa, qual seja, a narrativa da cultura hegemônica do Estado capitalista.

(...) A degradação da oralidade jurídica só tem verdadeiramente lugar no século XIX e é só então que se impõe a lógica e a economia da escrita jurídica como fatores estruturantes da prática e do discurso jurídico. Os marcos mais significativos deste processo são os seguintes: o grande movimento de condificação posterior à revolução francesa; a emergência de uma ciência jurídica capaz de proporcionar à prática jurídica uma consciência teórico-abstrata e um suporte técnico; a aplicação dos princípios e critérios da administração burocrática à administração da justiça; a tendência para a profissionalização plena da produção jurídica decorrente da aceleração da divisão social e técnica do trabalho jurídico e, portanto, da expansão e diversificação interna das profissões jurídicas; a reforma do ensino jurídico no sentido da apropriação monopolítica deste por parte de titulares da ciência jurídica, um ensino centrado na escrita jurídica e na aprendizagem do domínio técnico dos códigos com a negligência ativa dos demais objetivos possíveis, quer dos objetivos mais amplos ligados á formação política filosófica e social dos juristas, quer dos objetivos mais empíricos e "comezinhos" da preparação para a prática (em boa medida ainda oral) dos tribunais. ${ }^{193}$

Como comenta, ainda, Ana Lucia Pastore:

Por fim, a maior parte das faculdades de direito, das escolas de advocacia e de escolas profissionais da magistratura e do ministério público, mesmo em seus cursos voltados para a discussão dos direitos humanos, possuem corpos docentes majoritariamente formados por desembargadores, promotores, procuradores e advogados que reproduzem maneiras corporativas de abordar e estar no mundo. Daí serem escolas que mais educam para formatar comportamentos adequados a cada ethos profissional do que capazes de questionar conhecimentos e práticas que esses ethos (re)produzem. Tal fato parece também corriqueiro na maior parte dos cursos de pós-graduação em direito, bem como em muitos núcleos de prática jurídica.

(...)

Esse caminhar sem um único rumo pré-definido e sem medo de experimentar atalhos, parece ser o modo mais rico de ensinar antropologia do direito e de pesquisar direitos humanos, construindo, assim, não só o início de uma nova fase da história do ensino jurídico no Brasil, como preparando cidadãos profissionais mais sábios, humildes e eticamente envolvidos com suas escolhas e atuações. ${ }^{194}$

\footnotetext{
${ }^{193}$ Op. Cit. p.109.

194 Op. Cit.
} 
Diante desse cenário descrito por Boaventura de Sousa Santos e Ana Lucia Pastore é impossível pensarmos em juízes que estejam aptos a assumir o papel de mediadores de discursos num diálogo intercultural (como sugere Bauman) ou de professores, educadores, que assumam o papel de filósofos das fronteiras (como sugere Dussel).

A preocupação com a educação para os direitos humanos deve ser uma preocupação urgente dos cursos jurídicos, pois, como afirmamos, um primeiro passo deve ser dado. Sem juízes sensíveis para a interculturalidade não haverá interculturalidade no controle de políticas públicas que, no Brasil, tem íntima ligação com os empreendimentos capitalistas. Além dessa preocupação imediata, a educação para os direitos humanos também precisa ser objeto de reflexão para as práticas pedagógicas aplicadas tanto para a cultura hegemônica como para a cultura oprimida. Para que se proporcione a experiência da biculturalidade das fronteiras é fundamental que se facilite o livre fluxo de narrativas, de discursos e, antes que isso se faça no Direito, é preciso que seja feito na educação (dos operadores do Direito e de toda a sociedade), afinal, o Direito é apenas um reflexo de como os homens pensam; já a educação tem alguma influência sobre como os homens pensam.

Como proporcionar isso, como superar a supervalorização do discurso etnocêntrico é o que nos move a redigir estas reflexões. Somente o contato sensível com o outro pode nos proporcionar uma noção sensível da realidade que, no caso dos juízes, por exemplo, será antitética ao ponto de proporcionar, em confronto com as teorias puras, virgens e pudicas, uma síntese mais humana em forma de decisão corajosa. Em outros termos, somente assim poderemos superar a missão conferida à jurisdição por Chiovenda ${ }^{195}$ de ser um meio de tornar a lide juridicamente irrelevante e rumarmos em direção à concepção da jurisdição como um meio de tornar a lide humanamente irrelevante, pois humanamente solucionada.

195 Cf. CHIOVENDA, Giuseppe. La Acción en el Sistema de los Derechos, trad. esp. de Santiago Sentis Metendo, Bogotá, Temis, 1986. p. 52. A lide, enquanto fenômeno sociológico, não desaparece necessariamente com o exercício da função jurisdicional, a qual se limita, na verdade, a tornar a lide juridicamente irrelevante. (grifamos) 


\section{CAPÍTULO 5 \\ UM BALANÇO A PARTIR DOS SISTEMAS REGIONAIS DE PROTEÇÃO DOS DIREITOS HUMANOS}

A proposta de analisar os sistemas regionais de proteção dos direitos humanos tem o escopo de demonstrar que, no curso de desenvolvimento das reflexões acerca dos direitos humanos, existiram importantes manifestações de contrariedade e de posterior consenso entre culturas distintas. Antes, contudo, de realizarmos um estudo comparado, na medida do possível, dos diferentes sistemas regionais de direitos humanos, consideramos necessário lançar um olhar para o momento de internacionalização dos direitos humanos.

A fase de internacionalização ${ }^{196}$ dos direitos humanos teve início com o Direito Humanitário, a Liga das Nações, a luta contra a escravidão e a instituição da Organização Internacional do Trabalho pelo Tratado de Versalhes em 1919, intensificando-se após a $2^{\circ}$ Guerra Mundial e o início da Guerra Fria.

A segunda Guerra impulsionou a criação de órgãos de monitoramento e a Guerra Fria revolucionou o processo de internacionalização. No entanto, isso não significa que todas as culturas compreenderam a Declaração Universal dos Direitos Humanos e seus Pactos como documentos que veiculam direitos humanos e aspirações universais. Em 1994 a Liga dos Estados Árabes adotou a "Carta Árabe de Direitos Humanos", baseada, contudo, na lei de "sharia". Na Ásia, algumas lideranças vêm os direitos humanos como instrumento neocolonizador do Ocidente, tendo as ONGs importante papel para a divulgação e reflexão acerca dos direitos humanos.

No campo teórico do Direito Internacional dos Direitos Humanos surgiram as correntes universalistas e relativistas. Objeto das discussões polarizadas entre os universalistas e os relativistas, as premissas e conclusões dos monogenistas e dos relativistas na Antropologia, tal qual esboçadas no segundo capítulo, claramente aparecem

\footnotetext{
${ }^{196}$ Para uma análise mais sistemática desse processo, conferir também: CANÇADO TRINDADE, Antônio A. A Proteção Internacional dos Direitos Humanos. São Paulo: Saraiva, 1991; LAFER, Celso. A Internacionalização dos direitos humanos: o desafio do direito a ter direitos. In. Odilio Alves Aguiar; Celso de M. Pinheiro; Karen Franklin. (org). "Filosofia e Direitos Humanos". Fortaleza: UFC, 2006, vol. 4. p. 13-32.
} 
nos textos jurídicos que defendem uma e outra posição, evidenciando que tais ideias ainda não foram superadas no Direito. Ainda que relevantes sejam as bandeiras empunhadas pelos relativistas no âmbito do Direito Internacional e Constitucional, ${ }^{197}$ as discussões ficam travadas quando entram em pauta temas como vida, liberdade e soberania numa perspectiva intercultural. Notamos, nesses casos, um abandono quase que inconsciente da linha argumentativa vinculada ao direito à diferença e à concretização democrática de um diálogo intercultural representada pelos relativistas e um apego às regras e aos "standards" de um Direito posto desde o século XVIII e defendido, em termos, pelos universalistas.

Nossa sensação, e este é o ponto central da presente pesquisa, é que esse apego ao sistema jurídico que atualmente serve de paradigma universal nos casos em que emergem tensões que envolvem interculturalidade e Direito só ocorre em razão de uma incapacidade de se empreender, também na Política e no Direito, o salto qualitativo dado pela Antropologia no sentido de não mais se analisar os sistemas institucionais de outras culturas com base nas instituições do próprio investigador, como se fossem, aquelas, meras reconfigurações destas. E esse salto, por óbvio, só se deu na Antropologia após os antropólogos saírem de seus gabinetes e conviverem com o outro.

O que nos interessa desse processo de afirmação dos direitos humanos é exatamente o momento de sua internacionalização, onde a não adesão aos documentos internacionais emanados por instituições ocidentais representou, no início desse processo,

197 O ponto central de debate entre as duas correntes no Direito Internacional e Constitucional se situa na questão da soberania. Doutrinariamente existem três correntes acerca da matéria, quais sejam: 1- Monismo com prevalência do direito interno: $O$ primeiro aspecto é o do centralismo estatal e de sua pretensa autosuficiência. (...) o que mais caracteriza o monismo com prevalência do Direito Interno é a redução do Direito Internacional a Direito Estatal Externo. (Cf. GALINDO, George Rodrigo Bandeira. Tratados Internacionais de direitos Humanos e Constituição Brasileira. Belo Horizonte: Del Rey, 2002. p. 17); 2Monismo com prevalência do Direito Internacional: é a corrente que, não obstante reconhecer a necessidade de proteção das normas internas, pretende fazer a norma internacional prevalecer sobre a interna. 3- Dualismo: para essa corrente o Direito Internacional e o Direito Interno são sistemas absolutamente distintos. Para que as normas de Direito Internacional valham no Direito Interno, é necessário um processo de internalização. O Direito Internacional, portanto, não pode ser invocado por um Estado que tenha apenas ratificado determinado tratado; exige-se uma norma internalizadora. No Brasil, na prática jurídica, tem valido a regra definida pelo Supremo Tribunal Federal no Recurso Extraordinário 349.703/RS, ou seja, as normas de Direito Internacional (Tratados, Convenções etc.) terão natureza infraconstitucional, ou seja, não poderão contrariar nem a Constituição, nem as normas ordinárias, como Código Civil, Penal, Estatuto da Criança e do Adolescente, do Idoso etc. Já as normas de Direito Internacional que versem sobre direitos humanos terão estatuto "supralegal", ou seja, ficarão abaixo da Constituição e acima das leis ordinárias. Na hipótese de a internacionalização pelo Congresso Nacional se dar com um quórum de três quintos, os tratados de direitos humanos terão estatuto constitucional. Esse posicionamento do STF representou um certo atraso em relação à matéria, na medida em que, no âmbito latino-americano, existe a Opinião Consultiva n. 14 da Corte Interamericana de Direitos Humanos que, interpretando a questão, manifestou-se no sentido de que todos os tratados de direitos humanos, independentemente do quórum de internalização, deveriam assumir estatuto constitucional e ser efetivamente cumpridos pelos Estados signatários. Certamente a questão é de natureza eminentemente política e nada impede um novo posicionamento do Supremo Tribunal Federal, no futuro, quando a Corte estiver com outra composição. 
um protesto cultural e político muito interessante. Ainda que no curso do processo de internacionalização a grande parte dos Estados tenha aderido às principais Declarações e Pactos de Direitos Humanos da ONU, em evidente manifestação de reconhecimento, os sistemas regionais de proteção dos direitos nos parece representar um descontento ainda presente.

A Declaração Africana de Direitos Humanos e dos Povos (Carta de Banjul) foi adotada em 1981 pela então Organização da Unidade Africana, tendo entrado em vigor apenas em 1986. Desde 1995, conta com a adesão de todos os Estados africanos.

$\mathrm{Na}$ redação original da Carta de Banjul constava apenas a previsão de uma Comissão Africana sem poder de decisão vinculante. Apenas em 1998, com o Protocolo à Carta Africana, foi criada a Corte Africana dos Direitos Humanos e dos Povos, com sede na Etiópia. Como explica Flávia Piovesan, o "acesso à Corte é limitado à Comissão Africana, aos Estados e às organizações intergovernamentais africanas (...)". ${ }^{198}$

Flávia Piovesan apresenta quatro aspectos que diferenciam a Carta Africana dos outros instrumentos de proteção dos direitos humanos:

O primeiro deles é a atenção conferida às tradições históricas e aos valores da civilização africana. (...) A eles se conjuga o processo de libertação da África, a luta por independência e dignidade dos povos africanos, o combate ao colonialismo e neocolonialismo, a erradicação do apartheid, do sionismo e de todas as formas de discriminação.

$(\ldots)$

Diversamente dos demais instrumentos de proteção, em especial a Convenção européia e a Convenção Americana, a Carta Africana adota uma perspectiva coletivista, que empresta ênfase aos direitos dos povos. É a partir dessa perspectiva que se transita ao indivíduo.

Isso aponta ao terceiro aspecto da Carta, que é exatamente a previsão não apenas de direitos civis ou políticos, mas de direitos econômicos, sociais e culturais. (...)

Por fim, o quarto aspecto a ser destacado refere-se à concepção de deveres, na medida em que o preâmbulo da Carta afirma que o gozo dos direitos e liberdades implica o cumprimento dos deveres de cada um. ${ }^{199}$ (destacamos)

O primeiro documento internacional que reconheceu aos povos uma titularidade de direitos foi a Declaração Sobre a Concessão de Independência aos Países e Povos Coloniais - 1960 -, afirmando que a sujeição dos povos ao domínio estrangeiro é uma negação aos direitos fundamentais do homem. É a primeira vez que o "povo" aparece

\footnotetext{
${ }^{198}$ Op. cit. p. 136.

${ }^{199}$ Idem. p. 121/122.
} 
em uma posição importante no cenário internacional; no entanto, tanto nessa declaração como nos Pactos de 1966, que reconheceram o direito à autodeterminação dos povos, os direitos concedidos tinham em vista especialmente o "homem" enquanto parte de um povo. Basta analisarmos o teor da Declaração sobre a Concessão de Independência aos Países e Povos Coloniais para percebermos que o povo não era o objeto de seus preceitos: $a$ sujeição dos povos ao domínio estrangeiro é uma negação aos direitos fundamentais do homem. (destacamos)

Os povos receberam titularidade de direitos, efetivamente, através da Carta Africana de Direitos Humanos e dos Povos, talvez pela própria conjuntura na qual ela foi idealizada, ou seja, diante dos resultados da colonização e descolonização, quando os povos africanos se flagraram destituídos de identidade e de um caminho para reconstruíla.

O direito conferido aos povos de existirem enquanto tais tem relevante importância na medida em que existe no cenário internacional a tendência de se reconhecer apenas os Estados. Ocorre que algumas comunidades indígenas (como no caso da América Latina e da Austrália, p.ex.), ou comunidades africanas, não trocam diplomatas com outros Estados, e muito provavelmente não o farão. Isso, contudo, não deve ser obstáculo para o reconhecimento desses grupos como sujeitos de direitos humanos internacionalmente, como propôs a Carta Africana. Isso faz um muito sentido diante, por exemplo, do que dispõe o artigo $1^{\circ}$, item 3, da Convenção 169 da Organização Internacional do Trabalho ${ }^{200}$ : A utilização do termo "povos" na presente Convenção não deverá ser interpretada no sentido de ter implicação alguma no que se refere aos direitos que possam ser conferidos a esse termo no direito internacional. Ora, se o termo "povos", em relação aos "povos tradicionais", não pode ter de fato o efeito que assume no direito internacional, que tipo de efeito, então, teria?

O direito à livre disposição de suas riquezas também é imbuído de grande significado, especialmente no contexto em que foi idealizado. A história é repleta de exemplos de grupos sociais que praticaram estelionato contra outros grupos, haja vista o que foi feito com os primeiros habitantes da América Latina pelas riquezas minerais aqui existentes e em Serra Leoa em razão dos diamantes. Não obstante sua importância, esse direito deve ser compreendido em conjunto com o direito à preservação de um meio

\footnotetext{
${ }^{200}$ Vigente no Brasil desde 25 de julho de 2003.
} 
ambiente sadio, e aqui podemos citar a África como depósito de lixo e danos ambientais oriundos da exploração irracional de minérios.

Importante anotar também no sistema africano as disposições que dizem respeito aos direitos das mulheres, especialmente tratados no Protocolo à Carta Africana de Direitos Humanos e dos Povos Relativo aos Direitos das Mulheres na África de 2003 - mesmo já existindo a Convenção da ONU sobre a Eliminação de Todas as Formas de Discriminação Contra a Mulher - 1979. Muitos direitos assegurados às mulheres pelo sistema regional africano têm ligação com os direitos reconhecidos pelos documentos da ONU, o que representa não uma imposição vertical de valores ocidentais, mas uma conquista nascida no próprio seio da cultura africana e, o que é mais importante, pelas próprias mulheres africanas. No entanto, o que chama a atenção são as disposições não encontradas nas declarações da ONU. Uma disposição interessante diz respeito aos direitos das viúvas. O artigo 20 do Protocolo estabelece que:

Todos os Estados Parte tomarão as medidas necessárias para assegurar às viúvas o gozo de todos os direitos humanos através da implementação das seguintes provisões:

a) as viúvas não serão submetidas a tratamento desumano, humilhante ou degradante;

b) a viúva será automaticamente a guardiã de suas crianças, após a morte de seu marido, exceto se isso for contrário aos interesses e ao bem estar das crianças;

c) uma viúva terá o direito de se casar novamente e, nessa hipótese, de se casar com alguém de sua escolha. ${ }^{201}$

Etienne-Richard Mbaya, professor da Universitat zu Koln, Alemanha, em texto intitulado Gênese, evolução e universalidade dos direitos humanos frente à diversidade de culturas, ${ }^{202}$ apresenta a seguinte ideia:

Com todos os problemas e contradições - imensos, mas não insuperáveis uma dimensão característica da África e sua contribuição tradicional à idéia dos direitos do homem é precisamente seu humanismo, revelado de acordo com três pontos de partida e permitindo a ligação com os conceitos modernos nesse campo.

. o humanismo africano não fragmenta o indivíduo para destacar vários de seus componentes, com o intuito de valorizar o aspecto econômico em detrimento de outras característica: o homem é uma totalidade. (...)

\footnotetext{
${ }^{201}$ Article 20: States Parties shall take appropriate legal measures to ensure that widows enjoy all human rights through the implementation of the following provisions:

a) that widows are not subjected to inhuman, humiliating or degrading treatment;

b) a widow shall automatically become the guardian and custodian of her children, after the death of her husband, unless (exceto) this is contrary to the interests and the welfare of the children;

c) a widow shall have the right to remarry, and in that event, to marry the person of her choice.

${ }^{202}$ Op. Cit.
} 
. não aliena o indivíduo, visto não o considerar isoladamente, mais ou menos independente da sociedade da qual ele faz parte. Nenhum homem é uma ilha: esse ditado mostra-se particularmente verdadeiro na África. (...)

- os círculos concêntricos, embora unos, das relações individuais por se ampliarem da relação com os parentes até as do clã e da tribo, interpretam a realidade social, objetiva, de modo a compreender a humanidade como uma fraternidade. (...)

Flávia Piovesan atenta para o fato de que:

(...) recente estudo sobre o grau de cumprimento das decisões da Comissão Africana motiva preocupação, ao concluir que tem ocorrido cumprimento total das decisões em apenas $14 \%$ dos casos; cumprimento parcial em $20 \%$; e não-cumprimento em $66 \%$ dos casos. ${ }^{203}$

Ocorre que isso não pode servir de justificativa para a propagando "pró-ONU”, uma vez que não se trata de um resultado do reconhecimento e da intenção de tutela das particularidades culturais africanas. O baixo grau de cumprimento das decisões emanadas pelo sistema africano de proteção dos direitos humanos é resultado das ditaduras que ainda assolam o continente.

A leitura dos documentos árabes de proteção dos direitos humanos, por sua vez, evidencia uma intenção bastante distinta daquela que permeou a elaboração da Declaração Universal da ONU. A intenção islâmica foi evidentemente de um documento menos leigo, mais vinculado à religião islâmica. O Alcorão e a Sunnah são as bases das três declarações árabes de direitos, ${ }^{204}$ isso por que existe a crença de que somente Allah pode legislar sobre a humanidade e o Alcorão e a Sunnah (esta elaborada pelo profeta Muhammad) são leis divinas por excelência.

Em comunicação apresentada ao Seminário Internacional: Filosofia e Educação - os Orientes e o Ocidente -, na Faculdade de Educação da USP, em 2006, Marcelo Lamy anota:

Quando falamos dos direitos humanos no Islã queremos realmente dizer que esses direitos foram garantidos por Deus; não foram garantidos por algum rei ou por qualquer assembléia legislativa. Os direitos garantidos pelos reis ou por assembléia legislativa podem ser revogados da mesma maneira que foram conferidos. Dá-se o mesmo caso com os direitos aceitos e reconhecidos pelos ditadores. Eles podem conferi-los quando estão satisfeito e revogá-los quando desejarem; e podem

${ }^{203}$ PIOVESAN, Flávia. Direitos humanos e justiça internacional. São Paulo: Saraiva, 2006. p. 132.

204 Declaração de Direitos Humanos do Islã (1981 - de caráter não governamental); Declaração do Cairo (1990); Carta Árabe dos Direitos Humanos (1994 - assinada pela Liga dos Estados Árabes). Mesmo que no mundo árabe exista expressiva parcela de católicos, essas declarações são exclusivamente pautadas na cultura islâmica. 
abertamente violá-los quando quiserem. Mas, uma vez que no Islã os direitos humanos foram conferidos por Deus, nenhuma assembléia legislativa no mundo ou qualquer governo na terra tem o direito ou a autoridade de fazer qualquer emenda ou troca nos direitos conferidos por Ele. Ninguém tem o direito de ab-rogá-los ou os revogar. Nem são eles direitos humanos básicos, conferidos no papel para efeito de show e exibição e negados na vida real quando o show acaba. Nem são conceitos filosóficos sem nenhuma sanção por trás deles. ${ }^{205}$

$\mathrm{Na}$ introdução da Declaração de 1981 consta: (...) nós, como muçulmanos, acreditamos: (...) d) que a razão por si só, sem a luz da revelação de Allah, não pode ser um guia certo nas questões do ser humano (...). Não obstante ter vinculado a razão a uma causa divina, os muçulmanos perceberam antes do que os ocidentais que a razão, sozinha, não é capaz de resolver de maneira satisfatória os problemas do ser humano.

A Carta de 1994, em seu preâmbulo, transparece maior atenção à proteção da cultura árabe do que a Declaração de 1981. Talvez isso tenha ocorrido em razão dos impactos sofridos pelo mundo árabe após o final da Guerra Fria. Maior expressão disso está no artigo 35 da Carta que eleva o nacionalismo Árabe à condição de "fonte de orgulho". 206

Algumas particularidades merecem referência. A mulher, por exemplo, tem seus direitos assegurados desde a Declaração de 1981. A despeito de eventuais retaliações morais por parte dos cidadãos, a Declaração de 1981 (portanto, antes mesmo de nossa atual Constituição Federal) já reconhecia o divórcio no capítulo referente aos Direitos das Mulheres Casadas. Na mesma linha, o item XIX, $i$, da referida Declaração dispõe: Ninguém deverá se casar contra sua vontade, nem perder ou sofrer diminuição de sua personalidade legal por conta do casamento.

Por fim, outra peculiaridade merece atenção e diz respeito à proteção das minorias, diante do que dispõe o artigo 37 da Carta de 1994, ou seja, que as minorias não serão privadas de seus direitos de gozarem suas culturas e seguirem os ensinamentos de suas religiões. ${ }^{207}$

${ }^{205}$ LAMY, Marcelo. A universalização dos Direitos Humanos e a especialidade do pensamento islâmico. Coleção "Pensamento e Criatividade", n.5 - Filosofia e Educação: O Ocidente e os Orientes, 2006. p. 71-83. Também disponível em: <http://www.esdc.com.br/diretor/artigo_universalizacaoDH.htm>. Acesso em: 22 de outubro de 2007.

${ }^{206}$ Article 35: Citizens have a right to live in an intellectual and cultural environment in which Arab nationalism is a source of pride, in which human rights are sanctified and in which racial, religious and other forms of discrimination are rejected and international cooperation and the cause of world peace are supported.

${ }^{207}$ Article 37: Minorities shall not be deprived of their right to enjoy their culture or to follow the teachings of their religions. 
$\mathrm{Na}$ Ásia não existe ainda um sistema estruturado como na América, na Europa e na África, com Cortes e Comissões especializadas e com competência consultiva e contenciosa. O estudo dos direitos humanos na Ásia demonstra que a luta pela aceitação e promoção desses direitos no continente tem sido encabeçada especialmente por organizações não governamentais. A elaboração da Carta Asiática de Direitos Humanos de 1997 foi liderada pela Asian Human Rights Comission e recebeu a adesão de outras entidades também desvinculadas dos governos.

Muitas lideranças asiáticas demonstram bastante ceticismo com relação aos direitos humanos por verem neles, segundo Flávia Piovesan, uma expressão da agenda neo-colonizadora do mundo ocidental, ${ }^{208}$ o que se evidencia pela leitura da introdução da Carta Asiática de Direitos Humanos, no seguinte sentido: A Carta afirma a universalidade de todos os direitos humanos - um princípio atacado pelos governos na região, tanto retoricamente como na lei e na prática. ${ }^{209}$ Tanto é assim que, pela Declaração de Bangkok - 1967 -, os governos da Indonésia, de Singapura, da Malásia, das Filipinas e da Tailândia, endossaram os princípios do respeito à soberania nacional e da proibição da utilização dos direitos humanos como instrumento de pressão política, pregando a responsabilidade dos países do Sudeste da Ásia em assegurar a estabilidade e segurança das interferências externas em qualquer forma ou manifestação de forma a preservar a identidade nacional em conformidade com os ideais e aspirações de seus povos. $^{210}$

A análise panorâmica da Carta Asiática de Direitos Humanos - 1997 , elaborada eminentemente por ONGs, demonstra uma crença muito grande nos documentos internacionais de direitos humanos, em especial os documentos da ONU. À primeira vista chega-se ter a impressão de que a proposta da Carta é exclusivamente aderir ao sistema imposto pela ONU. Vejamos: (...) A aderência aos standards universais, como a Convenção de Direitos Civis e Políticos e à Convenção de Direitos Econômicos, Sociais

\footnotetext{
${ }^{208}$ Op. cit. p. 52 , nota 43.

209 The People's Charter affirms the universality of all human rights -- a principle often attacked by governments in the region, both rhetorically and in law and practice.

${ }^{210}$ CONSIDERING that the countries of South East Asia share a primary responsibility for strengthening the economic and social stability of the region and ensuring their peaceful and progressive national development, and that they are determined to ensure their stability and security from external interference in any form or manifestation in order to preserve their national identities in accordance with the ideals and aspirations of their peoples;
} 
e Culturais, deve servir como pedra fundamental para qualquer mecanismo futuro de direitos humanos. ${ }^{211}$

A expressão mais significativa da compreensão da realidade da natureza humana e da necessidade de um trabalho rumo ao universal, a partir dos próprios asiáticos, está no item 6.2 da Carta: Devemos transcender o conceito tradicional de família baseado nas tradições patriarcais, bem como recuperar em cada uma de nossas tradições culturais a diversidade das regras familiares que garantam os direitos das mulheres. Devemos ser corajosos para reinterpretarmos nossas crenças religiosas que ensejam desigualdades. ${ }^{212}$ Assumir a responsabilidade pela reinterpretação de crenças religiosas é uma das medidas mais louváveis e que demonstram maior compreensão da necessidade de um consenso que encontramos no estudo dos documentos que tratam a respeito dos direitos humanos.

Notamos que a cultura (relações sociais e religião) não foi atirada à condição de bárbara ou atrasada. A cultura foi reconhecida pelo item 6.1 como um direito à vida e como um meio de resistência individual e grupal às pressões econômicas e às mudanças sociais $^{213}$ (reconhecimento da cultura como elemento de identidade, conforme analisamos na primeira parte do presente trabalho). Essa compreensão a respeito das diferenças, da importância da cultura, da necessidade de revisão de paradigmas em prol de um consenso universal a fim de se proporcionar uma comunhão de esforços demonstra que todo esse progresso não pode ocorrer de forma arbitrária.

211 The People's Charter calls for the adoption by governments of a regional convention on human rights. While such a regional convention might be a positive development over the longer term, Amnesty International believes the overwhelming and immediate priority is broader ratification and implementation of existing international standards by governments in the Asia-Pacific region. Widespread adherence to international standards, such as the International Covenant on Civil and Political Rights and the International Covenant on Economic, Social and Cultural Rights, should serve as the foundation stone for any future regional human rights mechanism.

${ }^{212}$ 6.2 The plurality of cultural identities in Asia is not contrary to the universality of human rights but rather as so many cultural manifestations of human dignity enriching universal norms. At the same time we Asian peoples must eliminate those features in our cultures which are contrary to the universal principles of human rights. We must transcend the traditional concept of the family based on patriarchal traditions so as to retrieve in each of our cultural traditions, the diversity of family norms which guarantee women's human rights. We must be bold in reinterpreting our religious beliefs which support gender inequality. We must also eliminate discriminations based on caste, ethnic origins, occupation, place of origin and others, while enhancing in our respective cultures all values related to mutual tolerance and mutual support. We must stop practices which sacrifice the individual to the collectivity or to the powerful, and thus renew our communal and national solidarity.

${ }^{213} 6.1$ The right to life involves not only material but also the moral conditions which permit a person to lead a meaningful existence. This meaning is not only individually determined but is also based on shared living with other human beings. The Asian traditions stress the importance of common cultural identities. Cultural identities help individuals and communities to cope with the pressures of economic and social change; they give meaning to life in a period of rapid transformation. They are the source of pride and security. There are many vulnerable communities in Asia as elsewhere whose cultures are threatened or derided. Asian peoples and governments must respect the cultures and traditions of its diverse communities. 
Outra expressão de tolerância não encontrada em quaisquer outros documentos está no item 8.1 da Carta Asiática, que dispõe: Nossos estados e sociedade têm se tornado pouco tolerantes com as minorias e os povos indígenas, os quais têm tido seus mais básicos direitos violados. Muitas das nossas sociedades ainda discriminam os gays e as lésbicas, negando a eles identidade e causando muita angústia e miséria.

O surgimento dos sistemas regionais de proteção dos direitos humanos não é uma recusa pura e simples do sistema nascido com a ONU. Uma afirmação nesse sentido de fato desconsideraria as inúmeras adesões no final do século $\mathrm{XX}$ ao modelo da ONU. No entanto, o que significa esse surgimento de sistemas regionais de proteção dos direitos humanos é uma manifestação não por direitos positivados (o que se resolveria com intervenções políticas na própria ONU, diplomaticamente), mas um movimento de construção e afirmação culturalmente auto-referenciadas de discursos sobre os sentidos particulares dos direitos humanos.

A essência do sistema africano não está no direito das viúvas, mas no discurso da propriedade com foco não no sujeito de direito, mas nos povos. A essência do sistema islâmico não está em uma ou outra peculiaridade do casamento constante da Carta do Cairo, mas sim no exercício de direitos com foco não no sujeito de direito, mas no sujeito de espírito, com fundamento em leis divinas.

Esse movimento dos sistemas regionais asiático, islâmico e africano paralelamente ao sistema da ONU pode fornecer subsídios importantíssimos para a luta por reconhecimento e autonomia dos povos indígenas. Nesse particular se aplica perfeitamente a questão suscitada por Cançado Trindade relativamente à "passagem do consentimento ao consenso" no Direito Internacional. ${ }^{214}$ A esse respeito Cançado Trindade chama a atenção para a necessidade de se compreender um momento de superação dos limites das fontes formais do Direito Internacional consagradas no artigo 38 do Estatuto da Corte Internacional de Justiça e focadas na noção de consentimento.

No texto A formação do direito internacional contemporâneo: reavaliação crítica da teoria clássica de suas fontes, Cançado Trindade propõe o consenso como fonte do Direito Internacional e vincula a ideia do "consenso" com a noção de "consciência jurídica universal". A proposta de superação do consentimento em busca de um consenso é extremamente relevante para discussões políticas de direitos humanos que envolvam teoria do Estado.

214 CANÇADO TRINDADE, Antônio A. A Humanização do Direito Internacional. Belo Horizonte: Del Rey, 2006. p. 30-96. 
Assim, ao erigir o "sujeito" como centro e destino dos direitos, a sistemática consagrada na Declaração Universal não tutelou um valor humano, senão o que para Panikar é apenas um valor impregnado de humanidade, ${ }^{215}$ fato que, aliás, fez com que a Organização da Unidade Africana adotasse, em 1981, a Carta Africana de Direitos Humanos e dos Povos (Carta de Banjul), que em seu preâmbulo consigna:

\footnotetext{
Reconhecendo que, por um lado, os direitos fundamentais do ser humano se baseiam nos atributos da pessoa humana, o que justifica a sua proteção internacional, e que, por outro lado, a realidade e o respeito dos direitos dos povos devem necessariamente garantir os direitos humanos;
}

Assim, mostra-se relevante a noção de que a ideia da interculturalidade (mais do que simples relativismo) seria a concepção de que o todo deve existir, sim, em prol das partes, mas para isso se faz necessário que as parte estejam conscientes de que existem pelo todo. $\mathrm{O}$ que queremos defender, nessa linha, não é a permissão para que os homens façam o que bem entenderem, pois isso seria legitimar, mediante um discurso retórico de defesa de culturas, as barbáries cometidas dentro dos limites de cada cultura.

A pré-disposição científica para repudiar culturas diferentes, para considerá-las como primitivas ou atrasadas, acabou por legitimar algumas intervenções do Ocidente em outras culturas sob o pretexto de estar colaborando para o desenvolvimento da democracia de todas elas. No entanto, essa concepção superficial de progresso, a tendência de analisar "cultura" com base em premissas evolucionistas ou etnocêntricas, como se as escolhas humanas pudessem ser alocadas em um itinerário de desenvolvimento linear, colaborou para que, até hoje, os seres humanos não tenham logrado falar de direitos humanos sem, ao mesmo tempo, excluir direitos e seres humanos.

A universalização do Direito não pode ser compreendida simplesmente como um anseio bem sucedido do movimento de internacionalização dos direitos humanos gestado a partir da Declaração Universal dos Direitos Humanos de 1948. Muito mais do que isso, e talvez antes disso, o anseio pela construção de um cenário econômico que proporcionasse segurança à globalização econômica parece ter sido o real motivo da luta incessante e exitosa no sentido da internacionalização de um único sistema de Direito, de uma única ordem jurídica e de uma única concepção de sujeito de direito, qual seja, a ocidental (capitalista e judaico-cristã).

\footnotetext{
${ }^{215}$ Op. Cit. p. 22 .
} 
Vivemos um processo de globalização retoricamente explicado como "globalismos localizados", mas que, na realidade, tem sido um processo inverso vertical que Boaventura de Sousa Santos denomina de "localismos globalizados" que, para o professor português, é:

(...) processo pelo qual determinado fenômeno local é globalizado com sucesso, seja a atividade mundial das multinacionais, a transformação da língua inglesa em língua franca, a globalização do fast food americano ou da sua música popular, ou a adoção das leis de propriedade intelectual ou de telecomunicações dos EUA. ${ }^{216}$

Existem problemas universais, sim, que exigem regras de cunho universal, como regras de defesa do meio ambiente, regras relativas a epidemias e de respeito às diferenças culturais. No entanto, isso não é bastante para pensarmos em universalismos abstratos! Para pensarmos em universalismo, precisamos pensar também na elaboração de um topos universal. Ocorre que um topos universal, uma identidade universal, ainda é uma proposta bastante distante em um mundo composto por várias culturas e vários submundos, às vezes sem conhecimento de suas próprias particularidades, às vezes voltados apenas para seus próprios interesses.

Como anota Lévi-Strauss, as declarações de direitos do homem têm a força de pregar a igualdade, tendo, no entanto, também uma fraqueza, qual seja: (...) enunciar um ideal que raramente atenta para o fato de que o homem não realiza sua natureza numa realidade abstrata, mas em culturas tradicionais ${ }^{217}$. A diferença é uma constatação evidente, que não exige esforços.

Joaquín Herrera Flores inicia sua obra Teoria Critica dos direitos

Humanos: os direitos humanos como produtos culturais, tecendo relevantíssima consideração:

(...) Quer dizer, toda formação social constitui um processo cultural, ou seja, uma forma particular e concreta de reagir diante dos entornos de relações que seus componentes mantêm entre eles, consigo e com a natureza. De tal modo isso assim, que todos os processos de reação diante da realidade (entendida como entornos de relações), sempre e a todo momento, hão de ser considerados tão culturais como qualquer outra forma de reação diante do mundo. Por essa razão, afirma Goethe, só poderemos tomar consciência do outro quando admitimos que há algo que é quase intraduzível, um algo que é próprio de outro processo cultural e que nós devemos reconhecer como o que é: uma relação tão cultural como as múltiplas reações culturais que colocamos em funcionamento a cada dia no marco de nossas percepções de mundo. Culturalmente falando, não há um processo cultural mais importante, mais válido ou legítimo, que outro. Não é que tudo valha o mesmo. Não

\footnotetext{
${ }^{216}$ Op. cit.. p. 24 .
}

${ }^{217}$ Op. cit. p. 335 
é nossa intenção reforçar algum tipo de relativismo ético. Ao contrário, o que propomos é um "relativismo relacional" cujo pressuposto básico radica em considerar que todas as formas de relação com o mundo devem ser consideradas nos agradem ou não - como relações culturais, quebrando com isso toda pretensão de uniformidade e homogeneização do mundo em que vivemos. ${ }^{218}$

Os "dealers" do cenário internacional do século XXI, que assumem posição de comando por razões econômicas vinculadas à dominação do mercado internacional, são praticamente os mesmos que outrora foram os principais interessados no sucesso das correntes evolucionistas ou relativistas positivistas com vistas à colonização e, posteriormente, industrialização do mundo.

Os discursos pela internacionalização e universalidade dos direitos humanos, e essa é nossa proposta, não deve ser considerado o berço político da interculturalidade no âmbito internacional. Isso por que o início desse movimento foi eivado de perseguições aos países do terceiro mundo, como muito bem demonstrou Benoni Belli na sua obra A politização dos direitos humanos, ${ }^{219}$ onde propõe que a sistemática dos direitos humanos, especialmente no pós-Guerra Fria, se travestiu em instrumento de perseguição de países do terceiro mundo ou que assumiram a ideologia comunista.

Ao contrário do que se costuma pregar - ou seja, que a ideia apriorística da universalidade dos direitos humanos significou um espaço de abertura para as tensões interculturais - tem sido a presença da interculturalidade no âmbito internacional (e nacional) que, muito recentemente, ao demandar do Direito oficial garantia de direitos, tem ensejado tensões políticas imprescindíveis para a construção dialógica de um universal que, situado no futuro, não será estático, nem a priori e não prescindirá de tensões e crises estruturais nos discursos jurídicos que hoje orientam a ordem internacional. Assim, o diálogo intercultural não nascerá do Direito, mas da presença política de culturas não ocidentais nos espaços públicos. O Direito será uma consequência se se tornar intercultural, mas só depois que os homens, responsáveis pela sua criação e realização, estiverem preparados para a interculturalidade.

Superar os discursos unilaterais em um ambiente de diálogos simétricos e permanecer caminhando rumo às construções discursivas particulares, como tem feito os novos movimentos sociais e os sistemas regionais de proteção dos direitos humanos, nos parece o sentido a ser dado à luta pela construção de um espaço realmente intercultural.

\footnotetext{
${ }^{218}$ FLORES, Joaquin Herrera. Teoria Critica dos direitos Humanos: os direitos humanos como produtos culturais. Rio de Janeiro: Lumen Juris, 2009.

${ }^{219}$ BELLI, Benoni. A politização dos direitos humanos. São Paulo: Perspectiva, 2009.
} 


\section{CONCLUSÃO}

Com o presente trabalho queremos analisar como o Direito poderia ter o sentido de suas regras definido através de diálogos interculturais. Para alcançarmos um nível conceitual e reflexivo que nos proporcionasse desenvolver essa proposta tivemos de superar uma série de preconceitos e paradigmas que determinavam inclusive a compreensão do nosso objeto de estudo.

Entender que o Direito não é um dado que, na realidade, se encontra com a mesma configuração seja qual for a sociedade ou cultura que o sistematiza; entender que as inúmeras configurações dos Direitos encontrados em sociedades não-ocidentais é fruto da própria lógica discursiva que o sistematiza do que de ausência de sistematização e técnica jurídica; compreender a relevância do discurso que confere sentido ao Direito e os obstáculos para que outros discursos possibiliem sentidos decorrentes de consensos ao invés de sentidos decorrentes de imposições etnocêntricas, enfim, compreender que a situação ainda colonial da América Latina e, em especial, do Brasil, dificulta que os povos indígenas desenvolvam de forma sólida a capacidade de se fazerem respeitar no diálogo intercultural foi essencial para que pudéssemos concluir que a emancipação para a convivência entre diferentes culturas exigirá tanto um foco nos indivíduos da cultura hegemônica, como um foco nos indivíduos da cultura oprimida.

Nessa linha, ainda, os discursos formulados a respeito da universalidade dos direitos humanos, por não considerarem a necessidade de superação da ideia de exclusivismo jurídico para a solução de conflitos interculturais, no máximo podem atingir a diferença com base na noção de tolerância, e não de convivência. Se for para pensarmos em Direito intercultural, então esse Direito deverá ser compreendido como o resultado de um consenso obtido por diálogos interculturais que discutem simetricamente o sentido desse direito. O problema disso é que a tolerância não se mostra suficiente para a concretização de um diálogo intercultural, pois pressupõe uma parte que determina as regras (quem tolera) e outra parte que é destinatária das regras (quem é tolerado).

Todo objeto cultural está intimamente vinculado a um papel de satisfação da expectativa social de identidade. A sociedade cria objetos para exteriorizar os elementos que a identificam, e busca, nesses objetos, os mesmos elementos identificadores exteriorizados. Esta é a razão pela qual a intervenção descontrolada de determinadas 
culturas sobre outras, ao ponto de destruir esses elementos de identidade, seus símbolos veiculadores de cultura (dentre eles o Direito, enquanto sistema oficial de sentidos organizativos), bem como as instituições responsáveis pela sua perpetuação, destrói, inclusive, a capacidade de recuperação de uma estrutura passada e impede a reconstrução de uma nova estrutura de identidade. Sendo o Direito um objeto cultural com a finalidade de veiculação de elementos de identidade e sentido das sociedades que o cria, impossível pensarmos a vinculação de uma cultura às normas criadas por outra cultura, de forma simplista, vez que, para a primeira, essas normas não terão sentido pelo simples fato de não consubstanciarem elementos de identidade a ela relativos.

Ao discutirmos direito humanos, não há como nos desvincularmos dos elementos de identidade dos destinatários desses direitos. Não há como exigirmos comportamentos humanos unilineares perante certas matérias, pelo fato mesmo de que os seres humanos, quando diante de problemas sem solução imediata, têm a tendência de recorrerem a topói que, por estarem ligados aos sistemas de referência de cada cultura, inevitavelmente serão responsáveis por soluções distintas, ao menos antes do diálogo que pretendemos defender na presente pesquisa.

Os movimentos sociais na América Latina têm demonstrado ser possível a articulação de demandas distintas sob uma mesma bandeira, e isso evidencia o poder do diálogo quando se pretende caminhar (ainda que para rumos distintos). A respeito de experiências exitosas nas articulações com outros movimentos sociais, interessante a análise feita por Vivian Urquidi et al.:

\begin{abstract}
De modo geral, a mobilização indígena é resultado de experiências políticas de organização e enfrentamento de décadas, e de uma série de articulações com outros setores da sociedade. Foi o caso dos movimentos de base junto à igreja no Peru, por exemplo; da aliança social com os sindicatos operários na Bolívia, ou do trabalho conjunto com as organizações não-governamentais no Brasil e na Colômbia. Na Guatemala, por sua vez, uma parte dos indígenas maias atuou articuladamente com movimentos armados de resistência civil e intelectuais de esquerda à ditadura militar. Como resultado, tem-se uma ampliação das bandeiras indígenas, incorporando demandas políticas de outros atores sociais do país, que favoreceram a consolidação da cidadania étnica. Paralelamente, outros setores da sociedade incorporam, dos indígenas, princípios de identidade e defesa que favorecem a reconstrução da noção abstrata de nação (ANDERSON, 1997). ${ }^{220}$
\end{abstract}

Nessa linha, retomamos a afirmação no sentido de que a experiência sensível intercultural deve ser pensada enquanto uma experiência educacional de base, a

${ }^{220}$ Op. Cit. 
ser realizada durante a infância, pois o homem já subjetivado com a certeza de seus conceitos e a segurança de poder fazer valer seus juízos pelo uso legitimado da força somente será determinado pelo medo real ou de perder aquela ou de perder outros bens fundamentais, daí a ideia de que se a revolução não for realizada através da educação, dificilmente conseguiremos pensar em revoluções pacíficas.

Somente um processo de educação para a diferença que passe a considerar e conferir importância para o contato humano sensível (e não literário, folclórico ou meramente bibliográfico) com o outro "estranho" pode proporcionar a construção de um cenário intercultural e democrático efetivo. No entanto, o trabalho pode ser mais complexo e moroso.

Atualmente a indústria cultural $^{221}$, que pode ser entendida como atividade extremamente bem organizada para a produção e inserção de desejos uniformes, previsíveis e controláveis nos sujeitos, é responsável por aquilo que Alicia Beatriz Dorado de Lisondo chamou de cultura do vazio no seu texto Cultura do vazio, patologias do vazio. Alicia Lisondo analisa os impactos que a ausência dos pais e a industrialização da reprodução causam na formação dos sujeitos, quando ao invés da criança se desenvolver na intersubjetividade, ela se desenvolve com a televisão, os games e outros vazios típicos da indústria cultural.

\footnotetext{
A era pós-moderna, "autística", induz uma perpetuação do vazio e da deterioração mental. A existência é consumida. $\mathrm{Na}$ era do consumo de massas, quando se privilegiam valores hedonistas, permissivos, individuais, assistimos à comoção da sociedade e dos costumes na contramão das exigências para a estruturação do psiquismo. Viver livremente - sem repressões - é o lema, penetrando até na educação, que banaliza o conceito freudiano numa psicanálise silvestre. ${ }^{222}$
}

Pensar em convívio sensível na Pós-Modernidade é pensar também a superação das primeiras influências recebidas pelas crianças. A solidão e o vazio mental não são simples buracos a serem preenchidos com um conteúdo qualquer. $O$ vazio que é fatalizado pela ausência de possibilidades emancipadoras na criança desde a primeira infância será responsável por uma série de patologias clínicas (ansiedade, perversão, sadismo). Um sujeito vazio, pervertido, sádico, não tem condições de viver experiências sensíveis, pois desde a infância não viveu a simbiose de carinho entre pessoas presentes,

${ }^{221}$ Cf. ADORNO, Theodor. Indústria cultural e sociedade. 4.ed. São Paulo: Paz e Terra, 2007.

222 Op. Cit. 
mas simplesmente viveu contatos vazios com babás, tutores de escolas maternais, motoristas, amigos virtuais, apresentadores de programas de televisão etc. e sempre no ritmo frenético de fugacidade típico do nosso tempo. Não existe uma relação sensível, mas uma relação de busca frenética por preenchimento, um consumo alucinado do outro ser humano que, e isso é fundamental, não pode existir em mim, pelo fato de nada existir em mim.

E apesar da possível sensação de distância, o Direito (no caso, o Direito oficial) está presente em cada linha dessas reflexões, pois sustenta todo o sistema da indústria cultural. Daí que pensar Direito, Direitos Humanos e Interculturalidade é uma tarefa simultânea de crítica, proposições e sensibilidade. Não estamos dizendo que a repressão de impulsos não deve existir. Não estamos defendendo que tudo vale e tudo pode, inclusive a barbárie sob justificativa religiosa, só a título de exemplo. O que defendemos é que essa repressão (e a cultura é repressão, tal qual o Direito) deve se dar pelo contato com o outro, em termos de escolhas e consensos, deixando de ser repressão e passando a ser limite, e não pela leitura pura e simples de etnografias mal contadas em livros de História que, apesar de até causar algum espanto, não chega nem perto da riqueza da experiência do convívio. O que estamos pensando é em como expandir o ser humano, ao invés de anular a humanidade que deveria existir nos corpos. Como afirmamos, a ausência de limite não é a proposta, mas a definição de limites por meio do convívio, da sensibilidade vivida no contato com o outro, que deverá ser conhecido, sentido, percebido.

A utilização do Direito positivo para tratar questões de natureza intercultural é mesmo uma característica do nosso tempo, imediatista, que prefere se valer da verticalização instrumental e ágil do poder da força ao invés de proporcionar um ambiente de convívio que, como qualquer convívio, será um momento eternizado por todo o tempo enquanto existir humanidade nos sujeitos que convivem. Novamente citando Alicia Lisondo: $O$ auge da materialidade como fim supremo, a recusa dos lutos, o contato superficial, as programações mecânicas, afogam a dimensão humana do ser e seu sofrimento. $^{223}$

A educação deve ser pensada em termos de convivência com o diferente, e não por meio de textos, filmes ou relatos que contam quem é o diferente. $\mathrm{O}$ 
recurso artístico é sempre louvável, mas a virtualização do mundo é uma patologia da educação ocidental, e talvez por isso cause tanta repulsa nos educadores indígenas.

\author{
Como afirma Eduardo Bittar:
}

A dignidade tem a ver com o que se confere ao outro (experiência desde fora), bem como com o que se confere a si mesmo (experiencia desde dentro). A primeira tem a ver com o que se faz, o que se confere, o que se oferta (instrumentos, mecanismos, modos de comunicação, tratamentos, investimentos, esclarecimentos, procesos informativos e educativos ...) para que a pessoa seja dignificada. A segunda tem a ver com o que se percebe como sendo a dignidade pessoal, como uma certa auto-aceitação ou valorizaçãode-si, com um desejo de expansão de si, para que as potencialidades de sua personalidade despontem, floresçam, emergindo em direção à superfície. ${ }^{224}$

Nesse sentido, a primeira concepção de dignidade emerge como prérequisito para a ideia de reconhecer o outro estranho como titular de respeito e de diálogo simétrico, na medida em que somente através do ato de conferir ao outro (que enseja a experiência desde fora) o respeito pelo seu direito de escolha dos atributos de sua própria dignidade (experiência desde dentro) é que a dignidade poderá ser garantida em todas as suas dimensões. Acontece que o ato de conferir dignidade ao outro exige sentir o outro e permitir que o outro sinta aquele que lhe dignifica. Novamente com Eduardo Bittar:

\begin{abstract}
A concepção que se propõe para a importância da expressão dignidade da pessoa humana, sobretudo na pós-modernidade, passa por uma compreensão não-unilateral das culturas, e muito menos centrista-ocidental das culturas, mas pela visão de que a afirmação da dignidade da pessoa humana, em territórios com amplas distinções culturais regionais, como é o caso do Brasil, ou mesmo projetando-se para fora do território do Estado, para se alcançar o plano das relações entre os povos, passa por um profundo respeito da diferença, bem como pela afirmação da multiculturalidade e da relatividade das concepções de dignidade, como forma mesmo de se realizarem valores com preocupações isomórficas.

Uma concepção de dignidade cultural da pessoa humana (versão pós-moderna da idéia de dignidade) está em fermentação em pleno bojo dos conflitos mais cruentos para a afirmação da lógica da dignidade universal da pessoa humana (versão moderna da idéia de diginidade). ${ }^{225}$
\end{abstract}

Nesse sentido, reafirma-se a necessidade de um diálogo intercultural para a implementação de um estatuto que definitivamente faça jus à atribuição de humanidade. Essa apropriação e absorção do outro, contudo, não podem ser obtidas por meio da canibalização cultural, daí a proposta de um diálogo intercultural e uma hermenêutica de mesmo estatuto, como analisado neste trabalho.

${ }^{224}$ Op. cit. p. 300.
${ }^{225}$ Op. cit. p. 305. 
Nesse sentido, ainda que a hermenêutica intercultural possa ser um instrumento importantíssimo para a promoção do diálogo intercultural como processo de adaptação do Direito posto, a educação intercultural deve ser a luz a orientar as políticas educacionais de modo a permitir a configuração, no futuro, de um ambiente social e político onde possamos falar em Direitos, em Direito Intercultural, em Histórias, em Medicinas, enfim, em Epistemologias, sempre no plural e nunca mais no singular.

É importante esclarecer que não sabemos como essa proposta vai se configurar no futuro. Isso não sabemos e não podemos dizer. Aliás, o futuro é indizível, pois não passível de ser sentido. No entanto, podemos ver no diálogo intercultural um fim em si mesmo, pois a experiência intercultural pode ser mais benéfica para a expansividade humana do que o monólogo colonial.

A dimensão que nos parece mais apropriada para a interculturalidade, enquanto espaço de convivência, é a dimensão do amor. Não o amor erótico, mas o amor em seu mais pleno sentido político. A dimensão do amor em sentido político desconstrói de forma certeira uma das mais conhecidas máximas que inconscientemente é reproduzida no Ocidente, qual seja: Ame o próximo como a si mesmo.

O próximo não deve ser amado como a mim mesmo, mas como ele mesmo, enquanto o outro estranho, sem que exista nesse ato de caminhar em sentido ao sujeito amado qualquer pretensão de encontrar o que quer seja de familiar. Zigmunt Bauman, analisando essa máxima, comenta:

\begin{abstract}
A invocação de "amar o próximo como a sim mesmo", diz Freud (em $O$ mal-estar na civilização), é um dos preceitos fundamentais da vida civilizada. É também o que mais contraria o tipo de razão que a civilização promove: a razão do interesse próprio e da busca da felicidade. (...)

Se eu amo alguém, ela ou ele deve ter merecido de alguma forma... "Eles o merecem se são tão parecidos comigo de tantas maneiras importantes que neles posso amar a mim mesmo; e se são tão mais perfeitos do que eu que posso amar neles o ideal de mim mesmo... Mas, se ele é um estranho para mim e se não pode me atrair por qualquer valor próprio ou significação que possa ter adquirido para a minha vida emocional, será difícil amá-lo". 226
\end{abstract}

A convivência enquanto convívio político na dimensão do amor pressupõe o diálogo como meio de troca de pontos de vista e de experiências com a intenção permanente de emancipar o outro para o nosso convívio, e não para dominar o outro. Essa emancipação do outro, ademais, não pode ter a pretensão de torná-lo alguém igual a mim; essa emancipação pressupõe exatamente a possibilidade de escolher e se fazer

226 BAUMAN, Zygmunt. Amor Líquido - sobre a fragilidade dos laços humanos. Trad. Carlos Alberto Medeiros. Rio de Janeiro: Jorge Zahar Editores, 2004. P.97. 
respeitar. Por não pretender anular e nem dominar o outro, quem ama se esforça não para tolerar e coexistir, mas para encontrar o ponto ótimo do convívio e, além disso, sem ter também a pretensão de ser ou ter no outro um complemento, pois cada parte que ama o faz consciente da integralidade dinâmica, autônoma e situada da outra parte. Somos integrais em situação, pois a plena integralidade é a humanidade, vala isotópica em potencial. A dimensão política do amor se traduz na busca do desenvolvimento emancipador de todos os envolvidos, ao mesmo tempo, cada qual do seu modo... e no seu próprio tempo.

Erich Fromm, em sua obra $A$ arte de amar, explica:

(...) Respeito significa a preocupação de que a outra pessoa cresça e se desenvolva como é. Respeito, assim, implica ausência de exploração. Quero que a pessoa amada cresça e se desenvolva por si mesma, por seus próprios modos, e não para o fim de servir-me. Se amo a outra pessoa, sinto-me um com ela, ou ele, mas com ela tal como é, não como eu necessito que seja para objeto do meu uso. É claro que o respeito só é possível se eu mesmo alcancei a independência; se puder levantar-me e caminhar sem precisar de muletas, sem ter de dominar e explorar qualquer outro. $\mathrm{O}$ respeito só existe na base da liberdade: "l'amour est l'enfant de la liberté", como diz velha canção francesa; o amor é filho da liberdade, nunca da dominação. ${ }^{227}$

O mundo dos humanos nunca será um ambiente repleto de risos e gargalhadas e satisfação; afinal, se o Céu existir de fato, o que nos dizem sempre é que lá é um lugar para onde vamos apenas depois de sairmos do mundo dos humanos. Mas aí já não haverá mais culturas, aí já não haverá mais etnias, nem gênero, nem nada a nos atormentar. $\mathrm{O}$ que nos instiga a pensar sobre os temas deste trabalho agora é a crença na possibilidade (e na constatação sensível da necessidade) de um mundo onde as lágrimas, o sangue, o desespero e a fome sejam dádivas concedidas não apenas a uma mesma parcela da humanidade, mas de um mundo onde as lágrimas, o sangue, o desespero e a fome, se forem tão fundamentais e imprescindíveis assim (como tem parecido ser), que também sejam dádivas distribuídas entre todos de forma igualitária, de modo que, quem sabe, aqueles que sempre foram os responsáveis por essas dores as sintam com força suficiente ao ponto de tomarem consciência, ainda em vida, que todo esse sofrimento é tão desnecessário quanto a própria ideia do Céu que eles inventaram para postergar para o nunca um mundo de paz que pode ser vivido de fato no tempo de agora.

${ }^{227}$ FROMM, Erich. A arte de amar. Trad. Milton Amado. Belo Horizonte: Itatiaia Editora, 1990. p.51. 


\section{ANEXO I \\ DOCUMENTO FINAL DO ACAMPAMENTO TERRA LIVRE 2011 PELO DIREITO À VIDA E À MÃE TERRA}

Nós, mais de 700 lideranças, representantes de povos e organizações indígenas das distintas regiões do Brasil, reunidos em Brasília-DF, por ocasião do VIII Acampamento Terra Livre, a maior mobilização indígena nacional, considerando o atual quadro de violação dos nossos direitos que se agrava dia a dia sob o olhar omisso e a conivência do Estado brasileiro, viemos de público manifestar a nossa indignação e repúdio pela morosidade e descaso com que estão sendo tratadas as políticas públicas que tratam dos nossos interesses e aspirações.

Animados pelo exemplo e o espírito de luta e coragem dos nossos antepassados, anciãos e caciques que nos presidiram, reiteramos a nossa vontade de continuar unidos na diversidade e de lutar acima das nossas diferenças pela garantia dos nossos direitos assegurados pela Constituição Federal de 1988 e leis internacionais de proteção e promoção dos direitos indígenas como a Convenção 169 da Organização Internacional do Trabalho (OIT) e a Declaração das Nações Unidas sobre os direitos dos Povos Indígenas.

Diante do Projeto de morte da ofensiva dos interesses do agronegócio, do latifúndio, dos consórcios empresariais, das multinacionais e demais poderes econômicos e políticos sobre as nossas terras e suas riquezas (naturais, hídricas, minerais e da biodiversidade), proclamamos a nossa determinação de defender os nossos direitos, principalmente quanto à vida e à terra e, se preciso for, com a nossa própria vida.

Não admitiremos que o que até hoje preservamos milenarmente - a Mãe Terra - contribuindo para a sustentabilidade ambiental e social do território nacional e do planeta, seja arrancado mais uma vez das nossas mãos ou destruído irracionalmente, como foi há 511 anos pelos colonizadores europeus, em detrimento da vida dos nossos povos e suas futuras gerações.

Não podemos admitir continuar sendo vítimas da voracidade do capitalismo neoliberal, do modelo de desenvolvimento depredador que impera no mundo, inclusive no nosso país, de forma implacável, sob o olhar omisso, a conivência e adesão explícita do governo atual.

Em nome de todos os povos e organizações indígenas do Brasil reivindicamos que a Presidenta Dilma Roussef torne realidade o seu compromisso de garantir o respeito aos direitos humanos, a 
justiça social, a sustentabilidade ambiental e social proclamada por ela na sua campanha e em viagens internacionais, considerando que nós os povos indígenas, relegados secularmente pelo Estado brasileiro e tratados como empecilhos ao plano de desenvolvimento e crescimento econômico do país, enquanto cidadãos e coletividades étnica e culturalmente diferentes, temos direitos assegurados pela Constituição Federal e tratados internacionais dos quais o Brasil é signatário que devem ser devidamente respeitados.

Dessa forma reivindicamos o atendimento das seguintes demandas.

\section{TERRAS: DEMARCAÇÃO E DESINTRUSÃO}

Que a FUNAI crie GTs para dar continuidade aos trabalhos fundiários, voltados a regularizar as terras indígenas, com metas claras para a demarcação, revisão de limites e desintrusão imediata, incluindo o julgamento de casos parados no Supremo Tribunal Federal (STF). A paralisação dos processos demarcatórios e a morosidade nas ações da FUNAI provocam o aumento de conflitos com os invasores das terras indígenas, alongando o sofrimento dos nossos povos e comunidades em todas as regiões do país, situação agravada pelas 19 condicionantes estabelecidas pelo STF.

A FUNAI deve contratar funcionários para atender as demandas específicas de demarcação das Terras Indígenas. O órgão deve ainda tomar providências contra servidores envolvidos com fazendeiros e contrários ao direito territorial dos nossos povos como no Mato Grosso do Sul.

Que não se adote a aquisição de terras para os povos indígenas como substituição do devido procedimento legal de demarcação das terras tradicionalmente ocupadas. Só admitimos esse procedimento em casos em que não se comprove a ocupação tradicional.

É falsa a informação pomposamente divulgada com freqüência pelo governo de que $95 \%$ das terras indígenas já foram demarcadas. Ao contrário, além de não ter sido demarcada essa totalidade, a maioria das terras indígenas continuam sendo invadidas, sem que todas as fases de regularização estejam concluídas: relatório de identificação, declaração de reconhecimento, colocação de marcos, homologação, registro, desintrusão. Isso em todas as regiões do país. O Acampamento Terra Livre, por meio da Articulação dos Povos Indígenas do Brasil (APIB) encaminhará ao Governo um levantamento deste mapeamento que revela a situação crítica das terras indígenas.

Reiteramos que a agilidade na conclusão das distintas fases do procedimento de regularização é necessária para diminuir a crescente judicialização que vem retardando a efetividade das 
demarcações concluídas pelo Executivo, vulnerabilizando as comunidades frente à violência de grupos contrários ao reconhecimento das terras indígenas e à sua proteção pela União.

Cabe, no entanto, lembrar que demarcar não é suficiente se o governo não adota medidas de proteção e sustentabilidade às terras indígenas, adotando programa especial para a fiscalização e proteção das terras indígenas nas faixas de fronteira, com a participação dos nossos povos e organizações.

\section{EMPREENDIMENTOS QUE IMPACTAM TERRAS INDÍGENAS}

Que o Governo da presidenta Dilma garanta a aplicabilidade da Convenção 169 da Organização Internacional do Trabalho (OIT) e da Constituição Federal, respeitando o direito dos nossos povos à consulta livre, prévia e informada, a respeito de empreendimentos que impactam as suas terras. É fundamental para isso que o governo regulamente e institucionalize o direito à consulta. Os povos indígenas devem ser devidamente informados quanto aos seus direitos evitando que acordos sejam firmados ou políticas de cooptação praticadas, em detrimento de seus direitos. No caso de comunidades impactadas por empreendimentos, a compensação decorrente deve ser permanente e destinada diretamente para a elas, que definirão de forma autônoma quem deverá gerenciar os recursos em questão. Não admitimos que essa gestão seja feita pela FUNAI ou qualquer outra instituição, sem se considerar este pressuposto.

Os nossos povos não podem mais ser vítimas de impactos sociais e ambientais na maioria dos casos irreversíveis provocados por estradas que cortam as terras indígenas, monocultivos (soja, cana da açúcar, bambu, eucaplipto, pinos), a pecuária, o uso de agrotóxicos e outros tantos projetos e empreendimentos econômicos que impactam de forma negativa a nossa vida e cultura, e provocam a judicialização das demarcações de terras, a perseguição e a criminalização de centenas de lideranças nossas. São usinas hidrelétricas como Belo Monte, Santo Antônio e Jirau, Estreito; projetos de transposição (Rio São Francisco), rodovias, mineração, rede elétrica de alta tensão, Pequenas Centrais Hidrelétricas (PCHs), mansões na orla marítima, assentamentos de colonização, criação de parques nacionais e áreas de preservação, portos, esgotos, usinas de álcool, pedreiras, exploração de calcário e areia, fábricas siderúrgicas, refinarias, gasodutos, termoelétricas, dentre outros. Pelo menos 434 empreendimentos atingem nossos territórios. Os programas desenvolvimentistas do governo federal, vinculados ou não ao Programa de Aceleração do Crescimento (PAC), vão gerar impactos em 182 terras indígenas, em pelo menos 108 povos. 
Por tudo isso, não admitimos que o governo "enfie goela abaixo" empreendimentos do Projeto de Aceleração do Crescimento (PAC) que ameaçam a continuidade e segurança física, psíquica e cultural dos nossos povos e comunidades.

\section{CRIMINALIZAÇÃO DE LIDERANÇAS INDÍGENAS}

Que as lutas dos nossos povos pelos seus direitos territoriais não sejam criminalizadas, sendo eles perseguidos e criminalizados na maioria das vezes por agentes do poder público que deveriam exercer a função de proteger e zelar pelos direitos indígenas.

Denunciamos a articulação existente entre o judiciário, órgãos de segurança e interesses privados, fazendeiros, sobretudo, para criminalizar líderes indígenas. Em alguns estados as polícias militar, civil e federal, e a força nacional ou são omissas ou são utilizadas para expulsar indígenas das terras retomadas. Os fazendeiros, como no sul da Bahia, formam milícias inclusive com a participação de membros da polícia militar e federal.

De acordo com o InfoPen/MJ, pelo menos 748 indígenas estão presos, sendo que muitos são lideranças e outras por luta são perseguidos, submetidas a atos de violência, processos judiciais e com ordem de prisão decretada. Em Pernambuco, a cabeça de uma das lideranças está anunciada por 500 reais.

Lideranças indígenas, mulheres e homens, são assassinados, e os criminosos estão soltos e não são tomadas providências. Reivindicamos que sejam julgados e punidos os mandantes e executores de crimes (assassinatos, esbulho, estupros, torturas) cometidos contra os nossos povos e comunidades.

Juízes ocupantes de terras indígenas ou que defendem interesses de fazendeiros e até de grileiros assentados em áreas demarcadas ou reivindicadas não podem julgar as ações relativas às nossas terras. Devem, portanto, serem impedidos uma vez que são partes interessadas nas ações.

Que o Ministério Público Federal não ofereça denúncia contra lideranças indígenas, uma vez que não se trata de crimes e sim de uma luta coletiva dos povos indígenas pela demarcação de seus territórios tradicionais e demais direitos coletivos constitucionalmente garantidos. O Ministério Público Federal, omisso em alguns casos, deve ao contrário assistir as comunidades e impetrar Habeas Corpus em favor das lideranças que sofrem o processo de criminalização quando em luta por seus territórios. 
Que seja fortalecida a Procuradoria da FUNAI, assegurando o retorno dos Procuradores para a sede das coordenações regionais do Órgão.

Que seja assegurada a liberdade de expressão e de luta dos nossos povos pela garantia de seus direitos, especialmente territoriais.

\section{REESTRUTURAÇÃO DA FUNAI}

Queremos uma Funai que deixe de atender aos interesses econômicos e do latifúndio, e que pare de ser órgão licenciador de obras que rasgam nossas terras. Queremos uma Funai com recursos suficientes para retirar os invasores de nossos territórios e, ao mesmo tempo, ter condições de concluir os procedimentos demarcatórios de nossas terras. Chega de paralisia nas demarcações. Queremos uma Funai com condições de defender nossos direitos coletivos e individuais, especialmente de nossas lideranças que são criminalizadas. Queremos um órgão presidido por alguém que realmente tenha compromisso com os interesses e aspirações dos nossos povos e comunidades.

Com a reestruturação da FUNAI, a violação dos nossos direitos se agravou. Os processos de demarcação ficaram paralisados e as terras desprotegidas, sem a presença dos chefes de postos. Que os postos e as coordenações regionais extintos com o decreto 7056, retornem. Considerando que o governo brasileiro violou a Convenção 169 da Organização Internacional do Trabalho (OIT), reivindicamos que esse decreto seja revogado, até que seja discutido e haja consenso com todos os Povos sobre como deve ser a reestruturação e que seja substituído o atual presidente, como tem reivindicado as regiões afetadas por este processo.

\section{Legislação Indigenista}

Que o presidente da Câmara dos Deputados inclua na ordem do dia o PL 2057/91 e crie a Comissão Especial para analisar o projeto em questão, a fim de permitir a discussão e apresentação de emendas, considerando as propostas dos nossos povos e organizações, visando à aprovação do novo Estatuto dos Povos Indígenas. Dessa forma, todas as questões de interesse dos nossos povos serão tratadas dentro desta proposta, evitando ser retalhadas por meio de distintas iniciativas legislativas que buscam reverter os avanços assegurados pela Constituição Federal.

Que o governo, por meio de sua bancada, assegure a tramitação e aprovação do Projeto de Lei 3.571/2008 que cria o Conselho Nacional de Política Indigenista (CNPI), instância deliberativa, normativa e articuladora de todas as políticas e ações atualmente dispersas nos distintos órgãos de Governo. Após cinco anos da existência da Comissão Nacional de Política Indigenista, está na hora 
da mesma ser substituída pelo Conselho, a fim de evitar maiores desgastes e dificuldades no interior de nosso movimento. Acreditamos que a CNPI já cumpriu a sua função após ter assegurado a consolidação e o encaminhamento do Projeto de Lei do Conselho, que realmente interessa aos povos e organizações indígenas.

\section{Saúde Indígena}

Que o Governo garanta os recursos financeiros suficientes para a implementação da Secretaria Especial de Saúde Indígena (SESAI) e a efetivação da autonomia política, financeira e administrativa dos Distritos Sanitários Especiais Indígenas (DSEI`s), com a participação plena e o controle social efetivo dos nossos povos e organizações nos distintos âmbitos, local e nacional, evitando a reprodução de práticas de corrupção, apadrinhamentos políticos, e o agravamento da situação de abandono e desassistência em que estão muitos povos e comunidades indígenas. Garantir, ainda, concurso público diferenciado e a capacitação de quadros indígenas para assumirem responsabilidades no atendimento à saúde indígena.

A demora na transição das responsabilidades da Funasa para a SESAI, em razão de interesses políticos partidários e corporativos, está gerando caos no atendimento básico e insegurança sobre a garantia do saneamento básico nas comunidades indígenas. O Governo da presidenta Dilma deve tomar providências para que os órgãos competentes cumpram as suas responsabilidades institucionais em bem da saúde dos nossos povos.

\section{Educação Indígena}

Que o Ministério da Educação assegure a participação dos povos e organizações indígenas na implementação dos territórios etnoeducacionais e que cumpra as resoluções aprovadas pela I Conferência Nacional de Educação Indígena de 2009.

\section{Código florestal}

Repudiamos a ofensiva da bancada ruralista, empenhada na alteração do Código Florestal que, certamente, provocará danos irreparáveis às nossas terras e aos recursos naturais que elas abrigam.

\section{Reforma Política}


Reivindicamos que no processo da Reforma Política, em curso no parlamento, seja considerado o direito dos nossos povos à participação, inclusive sendo estabelecida uma quota que garanta a nossa representatividade.

Brasília-DF, 05 de maio de 2011. 


\section{BIBLIOGRAFIA}

ADORNO, Theodor. Indústria cultural e sociedade. 4.ed. São Paulo: Paz e Terra, 2007.

ADORNO, Theodor W. Educação após Auschwitz. Trad. Wolfgang Leo Maar. $6^{\circ}$ reimpressão. Rio de Janeiro: Paz e Terra, 1995

ADORNO, T.W. De la relación entre sociologia y psicologia. In: ADORNO, Theodor W. Actualidad de la filosofia. Barcelona: Paidós, 1991.

ALMEIDA, Guilherme Assis. Soberania, cosmopolitismo e o direito internacional dos direitos humanos. (2008) Texto disponível no seguinte sítio eletrônico (acesso em 20 de novembro de 2011): $<\underline{\text { http://www.nevusp.org/downloads/down075.pdf }>}$

ALMEIDA, Guilherme Assis. Direitos Humanos e não-violência. São Paulo: Atlas, 2001.

AMADO, Jorge. O país do carnaval. (1931)

ANJOS, Robério N. Direito ao desenvolvimento de comunidades indígenas no Brasil. Tese de Doutorado em Direito - USP. 2009.

BARBOSA, Marco Antônio. Autodeterminação - Direito à Diferença. São Paulo: Plêiade, 2001.

BARBOSA, Marco Antonio. Direito Antropológico e terras indígenas no Brasil. São Paulo: Pleiade, 2001.

BAUMAN, Zygmunt. Amor Líquido - sobre a fragilidade dos laços humanos. Trad. Carlos Alberto Medeiros. Rio de Janeiro: Jorge Zahar Editores, 2004.

BAUMAN - Em busca da política. Trad. Marcos Penchel. Rio de Janeiro: Jorge Zahar Ed., 2000.

BAUMAN, Zygmunt. Legisladores e Intérpretes: sobre modernidade, pós-modernidade e intelectuais. Trad. Renato Aguiar. Rio de Janeiro: Jorge Zahar Ed., 2010.

BELLI, Benoni. A politização dos direitos humanos. São Paulo: Perspectiva, 2009.

BITTAR, Eduardo C. B. Democracia, Justiça e Direitos Humano: estudos de teoria crítica e filosofia do Direito. São Paulo: Saraiva, 2011.

BITTAR, Eduardo C.B. O Direito na Pós-Modernidade. Ed. 2, revista, atualizada e ampliada. - Rio de Janeiro: Forense Universitária, 2009, p. 493.

BITTAR, Eduardo C. B. O direito à tradição, as religiões de matrizes africanas e os direitos humanos. Seqüência, n. 61, p. 309-329, dez. 2010.

CÂMARA, Alexandre de Freitas. Lições de Processo Civil. Vol. I. Ed.17. Rio de Janeiro: Lumen Juris, 2008. 
CAMPOS, Edemilson A. A tirania de Narciso - alteridade, narcisismo e política. São Paulo: Annablume: FAPESP, 2001.

CANÇADO TRINDADE, Antônio A. A Humanização do Direito Internacional. Belo Horizonte: Del Rey, 2006.

CANÇADO TRINDADE, Antônio A. A Proteção Internacional dos Direitos Humanos. São Paulo: Saraiva, 1991.

CANOTILHO, J.J. Gomes. Direito Constitucional. Ed.5. Coimbra: Almedina, 1991.

CARDOSO DE OLIVEIRA, Roberto. Ação indigenista, eticidade e o diálogo interétnico. Estudos Avançados, volume 14, n. 40. Setembro/Dezembro 2000. p. 213-230

CARNEIRO DA CUNHA, Manuela. Cultura com aspas e outros ensaios. São Paulo: Cosacnaif, 2009.

CHIOVENDA, Giuseppe. La Acción en el Sistema de los Derechos, trad. esp. de Santiago Sentis Metendo, Bogotá, Temis, 1986.

CLASTRES, Pierre. Arqueologia da violência. Tradução de Paulo Neves. São Paulo: Cosac \& Naify, 2004.

DALLARI, Dalmo de Abreu. In. O Primeiro Habitante. MEDINA, Cremilda (org). Editora USP, ECA e CJE. 1992.

DALLARI, Dalmo de Abreu. Argumento Antropológico e Linguagem Jurídica. In: SILVA, Orlando Sampaio; LUZ, Lídia; HELM, Cecília Maria Vieira. "A perícia antropológica em processos judiciais." Florianópolis: Ed. da UFSC, 1994.

DIAZ-POLANCO, Héctor. Elogio de La Divesidad. Globalización, multiculturalismo e etnofagia. Editora Librisite.

DURKHEIM, E. A divisão do trabalho social. (1978)

DUSSEL, Enrique. Transmodernidad e Interculturalidad (Interpretación desde la Filosofia de la Libertación). UAM-Iz, Cidade do México, 2005. Também disponível em: $<$ http://pt.scribd.com/doc/56989586/TRANSMODERNIDAD-e-interculturalidad> Acesso em $24 / 10 / 2011$.

EVERETT, Daniel. Don't Sleep, There Are Snakes: Life And Language In The Amazonian Jungle. Ed.1. Panthenon Books, 2008.

FERRAZ JR., Tércio Sampaio. Introdução ao Estudo do Direito: técnica, decisão, dominação. Ed. 6. São Paulo: Atlas, 2011.

FERRAZ JR., Tércio Sampaio. A demarcação de terras indígenas e seu fundamento constitucional. In. "Revista Brasileira de Direito Constitucional”, n. 3, jan/jun. 2004. 
FLORES, Joaquin Herrera. Direitos Humanos, Interculturalidade e Racionalidade de Resistência. Sequência (UFSC), vol. 23, n. 44. 2002. ISSNe 2177-7055. p. 09 a 29.

FLORES, Joaquin Herrera. Teoria Critica dos direitos Humanos: os direitos humanos como produtos culturais. Rio de Janeiro: Lumen Juris, 2009.

FRASER, Nancy. e HONNETH, Axel. ¿Redistribución o reconocimiento? Un debate políticofilosófico. Trad. Pablo Manzano. Madrid: Ediciones Morata, 2006.

FREUD, S. O Estranho (1919). In. Sigmund Freud, Vol. XVII - Histórias de uma neurose infantil e outros trabalhos. Rio de Janeiro: Imago Editora.

FROMM, Erich. A arte de amar. Trad. Milton Amado. Belo Horizonte: Itatiaia Editora, 1990.

FROMM, Erich. Ter ou Ser? Rio de Janeiro: Jorge Zahar Editores, 1977.

GADAMER, H. G. O Problema da Consciência Histórica. Org. Pirre Fruchon. Trad. Paulo Cesar Duque Estrada. $2^{\circ}$ ed. Rio de Janeiro: Fundação Getúlio Vargas, 2003

GALINDO, George Rodrigo Bandeira. Tratados Internacionais de direitos Humanos e Constituição Brasileira. Belo Horizonte: Del Rey, 2002.

GEERTZ, Clifford. Nova luz sobre a Antropologia. Trad. Vera Ribeiro. Rio de Janeiro: Jorge Zahar Ed., 2001.

GEERTZ, Clifford. A Interpretação das Culturas. Rio de Janeiro: LTD, 1989.

GONZÁLEZ CASANOVA, Pablo. Colonialismo interno (uma redefinição). In: "A teoria marxista hoje. Problemas e perspectivas”. Boron, Atilio A.; Amadeo, Javier; Gonzalez, Sabrina. 2007 ISBN 978987118367-8.

GOULD, Stephen Jay. A falsa medida do homem. Trad. Valter Lellis Siqueira. Ed.2. São Paulo: Martins Fontes, 1999.

HABERMAS, J. A inclusão do outro. 3.ed. São Paulo: Loyola, 2007.

HANS, Kelsen. Teoria Pura do Direito. São Paulo: Martins Fontes, 2009.

HART, Herbert. O conceito de direito. Trad. Antonio de Oliveira S. Camara. Martins Fontes, 2009.

HERSKOVITZ, Melville J. Antropologia Cultural. Tomo I. $8^{\circ}$ ed. São Paulo: Mestre Jou, 1960.

HOLANDA, Sérgio Buarque de. Visão do Paraíso: os motivos edênicos no descobrimento e colonização do Brasil. São Paulo; Companhia das Lestras, 2010.

HONNETH, Axel. Luta por reconhecimento: a gramática moral dos conflitos sociais. 2.ed. São Paulo: Editora 34. 
HONNETH, Axel. In. Teoria Crítica no século XXI. Org. Jessé Souza e Patrícia Mattos.

HORKHEIMER, Max. Teoria Crítica e Teoria Tradicional. (1937). In. Textos Escolhidos - Benjamin, Horkheimer, Adorno, Habermas. (Coleção “Os Pensadores”). São Paulo: Abril, 1980.

KAFKA, Franz. O processo. Editora Companhia das Letras, 1998.

KYMLICA, Will. Ciudadanía Multicultural: una teoría liberal de los derechos de las minorías. Barcelona: Paidós, 1996.

KUPPE, R. \& POTZ, R. La Antropología del Derecho: perspectivas de su pasado, presente y futuro. In. Antropología Jurídica. Editora da Universidad Nacional Autónoma de México: México, 1995.

LAFER, Celso. A Internacionalização dos direitos humanos: o desafio do direito a ter direitos. In. Odilio Alves Aguiar; Celso de M. Pinheiro; Karen Franklin. (org). "Filosofia e Direitos Humanos". Fortaleza: UFC, 2006, vol. 4. p. 13-32.

LAMY, Marcelo. A universalização dos Direitos Humanos e a especialidade do pensamento islâmico. Coleção "Pensamento e Criatividade", n.5 - Filosofia e Educação: O Ocidente e os Orientes, 2006. p. 71-83. Texto também disponível no seguinte sítio eletrônico: <http://www.esdc.com.br/diretor/artigo_universalizacaoDH.htm>. Acesso em: 22 de outubro de 2007.

LARAIA, Roque de Barros. Cultura - um conceito antropológico. $15^{\circ}$ ed. Rio de Janeiro: Jorge Zahar Editora, 2002.

LÉVI-STRAUSS, Claude. Antropologia Estrutural Dois. $4^{\circ}$ ed. Rio de Janeiro: Tempo Brasileiro, 1993.

LIMA, Roberto Kant de. Ensaios de Antropologia e de Direito.Rio de Janeiro: Lumen Juris, 2008.

LINERA, Álvaro García. La potencia plebeya. CLACSO, Consejo Latinoamericano de Ciencias Sociales, Buenos Aires; PROMETEO libros, Buenos Aires. 2008.

LISONDO, Alicia Beatriz D. Na cultura do vazio, patologias do vazio. Ver. Brasileira de Psicanálise. Vol. 38 (2). P.335-358, 2004.

LYOTARD, Jean-François. A Condição pós-moderna. São Paulo: José Olympio, 2010.

MALINOWSKI, Bronislaw. Os Argonautas do Pacífico Ocidental. São Paulo: Ed. Abril, 1978.

MALINOWSKI, Bronislaw. Crime e Costume na Sociedade Selvagem. Brasília, Editora da UnB, 2003.

MARÉS, Carlos Frederico. As novas questões jurídicas nas relações dos Estados nacionais com os índios. In. "Além da tutela: bases para uma nova política indigenista III." Org. LIMA, Antonio Carlos de Sousa. HOFFMANN, Maria Barroso. Rio de Janeiro: Contracapa livraria, 2002. 
MARIÁTEGUI, José Carlos. 7 Ensayos de interpretació de La realidad peruana. 3.ed. Caracas: Fundação Biblioteca Ayacucho, 2007.

MBAYA, Etienne-Richard. Gênese, evolução e universalidade dos direitos humanos frente à diversidade de culturas. Estudos Avançados, vol. 11, n. 30. Agosto de 1997. p. 17-41.

MORGAN, L. Ancient Society. Arizona Press, UNIVE. 1985.

NOBRE, Marcos (org). Curso livre de Teoria Crítica. Campinas-SP: Papirus, 2008.

PANIKAR, Raimuno. É a Noção dos Direitos Humanos em Conceito Ocidental? DIÓGENES, Brasília. Editora UNB, 1983, nº 5. p. 20.

PERUZZO, P. P. A Tutela das diferenças a partir dos sistemas regionais de proteção dos direitos humanos. 2007.

PIOVESAN, Flávia. Direitos humanos e justiça internacional. São Paulo: Saraiva, 2006

SANTOS, Boaventura de Sousa. Por uma Concepção Multicultural de Direitos Humanos. Artigo em LADSLAU-BIANCO, Bela \& CAPINHA, Graça (organizadores). Identidades: estudos de cultura e poder. São Paulo: Hucitec, 2000.

SANTOS, Boaventura de Sousa. O discurso e o poder: ensaio sobre a sociologia da retórica jurídica. $2^{\mathrm{a}}$ reimpressão. Porto Alegre: Sergio Antonio Fabris Editor. 1988.

SANTOS, Boaventura de Sousa. A gramática do tempo: para uma nova cultura política. São Paulo: Cortez, 2006. p. 438.

SANTOS, Boaventura de Sousa. La reinvención del Estadoy el Estado plurinacional. Publicação da Alianza Interinstitucional CENDA, CEJIS, CEDIB. Bolivia, 2007. Texto disponível no seguinte sítio eletrônico: < http://bibliotecavirtual.clacso.org.ar/ar/libros/coedicion/boavent/cap\%205.pdf > Acesso em 12 de fevereiro de 2011.

SCHRITZMEYER, Ana Lúcia Pastore. $O$ ensino da antropologia jurídica e a pesquisa em direitos humanos. in Nalini, José Renato e Carlini, Angélica Luciá (org.). Formação Jurídica e Direitos Humanos. Rio de Janeiro: Forense, 2010.

SCHWARKCZ, Lilia M. O Espetáculo das Raças. São Paulo: Companhia das Letras, 1993.

TELLES-JR., Gofredo. Direito Quântico - Ensaio Sobre o Fundamento da Ordem Jurídica. $7^{\circ}$ ed. São Paulo: Juarez de Oliveira LTDA, 2003.

TEXEIRA, Vanessa C. A interculturalidade no Programa Nacional de Direitos Humanos e no Plano Nacional de Educação em Direitos Humanos. Texto apresentado na IX Reunião de Antropologia do Mercosul, 2011, disponível no seguinte sítio eletrônico: $<$ http://www.sistemasmart.com.br/ram/arquivos/ram_GT53_Vanessa_Teixeira.pdf $>$. Acesso em $10 \mathrm{de}$ novembro de 2011. 
THEREAU, Henry D. A Desobediência Civil. Porto Alegre: L\&PM Editores, 1997.

TYLOR, E. Primitive Culture. Editora Cambrige, USA. 2010.

URQUDI, Vivian Grace F. D. Descolonização e Estados Plurinacionais. $35^{\circ}$ Encontro Anual da Associação Nacional de Pós-graduação e Pesquisa em Ciências Sociais, 2011, Caxambu-MG. GT 26 Pensamento social latinoamericano. ANPOCS, 2011.

URQUIDI. V. TEIXEIRA, V. e LANA, E. Questão Indígena na América Latina: Direito Internacional, Novo Constitucionalismo e Organização dos Movimentos Indígenas, in Cadernos Prolam-USP, ano VII, Vol. I, 2008. p. 199-222.

VILLARES, Luiz Fernando . Direito e povos indígenas. 1. ed. Curitiba: Juruá, 2009.

WAGNER, Roy. A invenção da cultura. São Paulo: Cosac Naify, 2010.

WEBER, Max - A objetividade do conhecimento na ciência política e social -1904).

WOLKMER, Antonio Carlos. Introdução ao Pensamento Jurídico Crítico. 5.ed. São Paulo: Saraiva, 2006.

\section{SÍTIOS ELETRÔNICOS CONSULTADOS}

www.stf.jus.br

www.stj.jus.br

www.cidh.org

http://www.culturabrasil.org/cartadaterra.htm

http://www.culturabrasil.pro.br/zip/cartadaterra.rtf

www.mabnacional.org.br

http://www.ibge.gov.br/home/presidencia/noticias/noticia_visualiza.php?id_noticia=1476\&id_pagina= 1 